Evaluation of Nevada Test Site Ground Motion and Rock Property Data to Bound Ground Motions at the Yucca Mountain Repository

L.H. Hutchings, W. Foxall, J. Rambo, J.L. Wagoner

March 17, 2005 
This document was prepared as an account of work sponsored by an agency of the United States Government. Neither the United States Government nor the University of California nor any of their employees, makes any warranty, express or implied, or assumes any legal liability or responsibility for the accuracy, completeness, or usefulness of any information, apparatus, product, or process disclosed, or represents that its use would not infringe privately owned rights. Reference herein to any specific commercial product, process, or service by trade name, trademark, manufacturer, or otherwise, does not necessarily constitute or imply its endorsement, recommendation, or favoring by the United States Government or the University of California. The views and opinions of authors expressed herein do not necessarily state or reflect those of the United States Government or the University of California, and shall not be used for advertising or product endorsement purposes.

This work was performed under the auspices of the U.S. Department of Energy by University of California, Lawrence Livermore National Laboratory under Contract W-7405-Eng-48. 
Final Report for LDRD Exploratory Project on

\title{
Evaluation of Nevada Test Site Ground Motion and Rock Property Data to Bound Ground Motions at the Yucca Mountain Repository
}

Tracking Code: 04-FS-029

10 February 2005

\author{
Lawrence Hutchings, William Foxall, John Rambo, and Jeffrey L. Wagoner \\ Yucca Mountain Project \\ Lawrence Livermore National Laboratory
}

This work was performed under the auspices of the U. S. Department of Energy (DOE) by the University of California, Lawrence Livermore National Laboratory (LLNL) under Contract No. W-7405-Eng-48. The project (04-FS-029) was funded by the Laboratory Directed Research and Development Program at LLNL.

\section{Background}

Yucca Mountain licensing will require estimation of ground motions from probabilistic seismic hazard analyses (PSHA) with annual probabilities of exceedance on the order of $10^{-6}$ to $10^{-7}$ per year or smaller, which correspond to much longer earthquake return periods than most previous PSHA studies. These long return periods for the Yucca Mountain PSHA result in estimates of ground motion that are extremely high $(\sim 10 \mathrm{~g})$ and that are believed to be physically unrealizable. However, there is at present no generally accepted method to bound ground motions either by showing that the physical properties of materials cannot maintain such extreme motions, or the energy release by the source for such large motions is physically impossible.

The purpose of this feasibility study is to examine recorded ground motion and rock property data from nuclear explosions to determine its usefulness for studying the ground motion from extreme earthquakes. Our premise is that nuclear explosions are an extreme energy density source, and that the recorded ground motion will provide useful information about the limits of ground motion from extreme earthquakes. The data were categorized by the source and rock properties, and evaluated as to what extent non-linearity in the material has affected the recordings. We also compiled existing results of non-linear dynamic modeling of the explosions carried out by LLNL and other institutions. We conducted an extensive literature review to outline current understanding of extreme ground motion. We also analyzed the data in terms of estimating maximum ground motions at Yucca Mountain. 


\section{Compilation of Nuclear Explosion Data}

Strong ground motions were routinely recorded for many nuclear tests conducted at the Nevada Test Site (NTS). In addition to routine surface monitoring within $1 \mathrm{~km}$ of ground-zero, monitoring included more extensive strong- and weak-motion surface arrays and borehole-emplaced sensors for selected shots. The recordings span ground motions ranging from $\sim 0.01 \mathrm{~g}$ to tens of $\mathrm{g}$. Both raw and processed data collected for LLNL, LANL and Defense Nuclear Agency (DNA) tests have been gathered into archives at the respective laboratories (Sandia in the case of DNA tests). The strong motion data, together with rock properties (P-wave velocities, densities, moduli, porosities, etc) collected by coring and logging the emplacement hole for every test, have been used at LLNL and elsewhere to constrain finite difference modeling of wave propagation from selected explosions. These models include rock fracture and crushing under dynamic loading and the resulting non-linear wave propagation behavior in rock types similar to those at Yucca Mountain. Appendices 2 and 3 provide documentation of test data appropriate for ground motion studies.

\section{Analysis of Nuclear Explosion Data}

We evaluate whether the data available has been recorded in the linear-elastic or nonlinear regime near a nuclear explosion in Appendix 1. This is determined by examining the decay rate of the amplitude of recorded arrivals to determine whether they diminish due to geometrical spreading and attenuation, or whether rock non-linearities occur that affect the amplitude. If the waves are not elastic, then we determine their decay rate and decide whether extreme ground motions near a source propagate significantly far enough to be meaningful for earthquake hazard studies. We conducted an extensive literature review to see what has been done previously to describe the material response to nuclear explosions, and describe the cause of non-linearity. We also examined the theoretical relationship between failure in rock due to compressional loading and failure due to shear loading. Rock under confining stress (i.e. at depth) fail in shear under compressional loading. Rock subjected to shear also fail in shear. Finite difference modeling of NTS shots by John Rambo (LLNL, personal communication) confirms from his finite difference modeling that rock damage surrounding nuclear tests result in deformation adding to non-linear behavior usually results from shear failure under the first compressional arrival, and this may have relevance to non-linearity in shear waves. We also analyzed the data in terms of estimating maximum ground motions at Yucca Mountain due to shear waves based on observed rock damage, and constraining the form of modulus reduction curves at large strains.

\section{Conclusion of Feasibility Study}

The vast amount of ground motion data recorded during the U.S. underground nuclear testing program provides unique insights into material response and wave propagation and attenuation within the near-source regions of seismic events as large as $\sim$ M6. These regions extend from the zone of intense macroscopic damage and highly non-linear 
behavior under high strain and strain rate loading close to the detonation point through the transition to elastic wave propagation to the response of the free-surface, where material response again becomes non-linear owing to spalling under tensional failure. Much of this data set, together with instrument calibrations and material properties, is available to researchers through the archiving efforts at LLNL, LANL and SNL and will be useful to study extreme earthquakes.

There appears to be sufficient similarity in the damage and subsequent attenuation mechanisms produced by the two types of sources that it is likely that free-field recordings can provide important information to characterize highly non-linear energy dissipation mechanisms in the immediate source vicinity that limit extreme ground motions, and the transition through weak non-linearity to elastic wave propagation. 


\title{
LIST OF APPENDICES
}

\section{Appendix 1}

Extreme Ground Motion Recorded in the Near-source Region of Underground Nuclear Explosions

William Foxall

Appendix 2

(Attached as excel spreadsheet)

Jeff Wagoner

This spreadsheet shows the status of strong ground motion measurements for LLNL nuclear explosion events. Most of this information is from the containment library (T1406 Room 1110).

\author{
Appendix 3A \\ Memorandum for Excel Spread Sheet \\ John Rambo
}

\section{Appendix 3B}

(Attached as excel spreadsheet)

John Rambo

This spreadsheet shows the existence of free field ground motion data and the inclusion of some containment diagnostics. The information is stored in the LLNL DNT Containment Program Libraries. To access data see Gayle Pawloski or John Rambo. 


\section{Appendix 1}

Extreme Ground Motion Recorded in the Near-source Region of Underground Nuclear Explosions

William Foxall 


\title{
EXTREME GROUND MOTION RECORDED IN THE NEAR- SOURCE REGION OF UNDERGROUND NUCLEAR EXPLOSIONS
}

\author{
Bill Foxall \\ Lawrence Livermore National Laboratory
}

\begin{abstract}
Introduction
Free-field recordings of underground nuclear explosions constitute a unique data set within the near-source region of seismic events ranging in magnitude from M3 to M6.5. The term "free-field" in this context refers to recordings from instruments emplaced in boreholes or tunnel walls such that the initial portions of the records ( $\sim 0.1$ to 1 second) do not contain effects resulting from reflections at the free surface. In addition to the free-field instruments deployed to record ground motions from selected underground nuclear explosions at the Nevada Test Site (NTS) and elsewhere, surface arrays were routinely deployed to record surface accelerations and velocities from underground nuclear tests conducted at NTS.
\end{abstract}

Underground explosions are quite different from earthquakes in that they are compressional rather than shear seismic sources, have a much higher energy density, and are detonated much closer to the surface - generally on the order of $1 \mathrm{~km}$ or less - than typical earthquake focal depths. The loading and failure mechanisms in the surrounding materials are therefore fundamentally different. However, there appears to be sufficient similarity in the damage and subsequent attenuation mechanisms produced by the two types of sources that it is likely that free-field recordings can provide important information to characterize highly non-linear energy dissipation mechanisms in the immediate source vicinity that limit extreme ground motions, and the transition through weak non-linearity to elastic wave propagation. The data also hold the potential of constraining the mechanical properties of materials analogous to those at Yucca Mountain under high strain loading. Furthermore, both free-field and surface recordings are a rich source of information on near-surface spall produced by explosions, which can be used to calibrate field observations that J. Brune has proposed as a potential means of placing limits on ground motions from earthquakes.

In this paper we provide an overview of the types of data recorded during the U.S. underground nuclear testing program and their availability, and briefly discuss potential uses of the data in investigating the limits on ground motions generated by earthquakes.

\section{Instrument Arrays}

The vast majority of the U.S. underground nuclear tests carried out between the mid1950s and the end of testing in 1992 took place within three main areas at NTS, Yucca Flat, Pahute Mesa and Rainier Mesa. Detonation points of tests under Yucca Flat were in various tuff units or in the thick overlying alluvium section. Tests under Pahute Mesa and Rainier Mesa were detonated in tuffs, and were recorded on tuff and/or in thin 


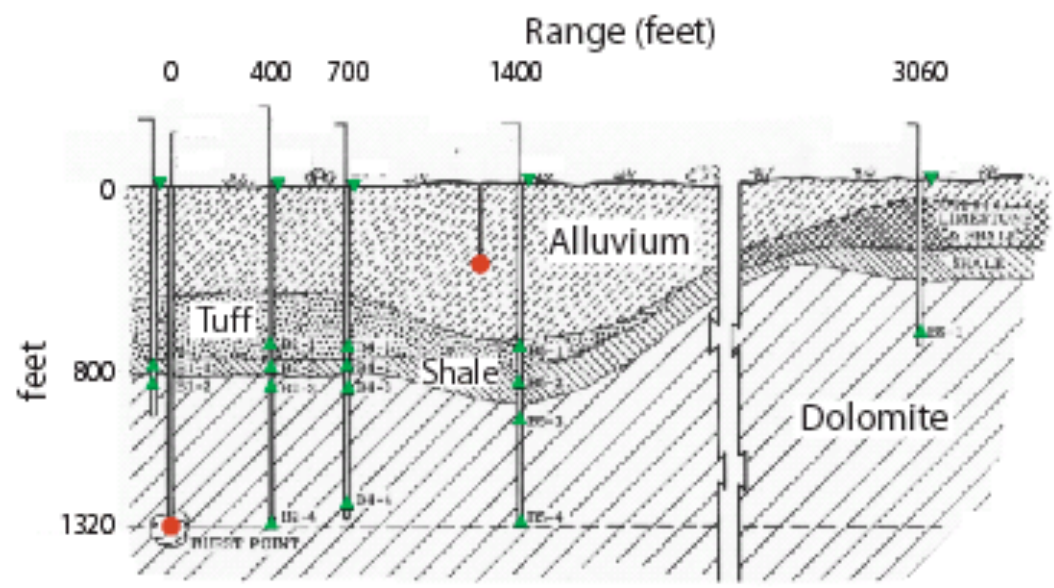

Figure 1: Surface and subsurface arrays (green) deployed for the HANDCAR_MUDPACK shots (red) superficial alluvium layers. The mechanical properties of shot point tuffs vary over a wide range, but include densely welded materials such as the Rainier Mesa member analogous to materials at repository depth at Yucca Mountain. Elaborate free-field and surface arrays of accelerometers and velocity sensors were deployed for

several of the earlier (pre 1974) events conducted as weapons tests or as part of the Plowshare program (peaceful uses), or for non-proliferation experiments. For example, Figure 1 shows the array deployed for the 1964 HANDCAR-MUDPACK events. A more typical layout consisted of a string of accelerometers and/or velocity sensors deployed in a single borehole offset 10-30 m from the device emplacement hole, as shown in Figure 2. Lawrence Livermore National Laboratory (LLNL), for example, deployed such arrays on average once per year from 1978 onwards with the specific objective of calibrating dynamic models of wave propagation and material response conducted for containment purposes. The surface arrays routinely deployed by LLNL, LANL and Sandia (SNL) generally recorded strong ground motions within surface ranges $\sim 1 \mathrm{~km}$ or less from surface ground zero, but extended to regional distances for certain special studies.

\section{Data Availability}

We have compiled spread sheets of events for which we know free-field and/or surface ground motion exist [Appendices 2 and 3]. These include tests carried out by all agencies involved in the test program, including LLNL, LANL, and the Department of Defense (DOD). Most of the ground motion data are held by LLNL, LANL and SNL. Of the 381 events presently in the spread sheet, 169 have free-field data, 164 surface data, and 44 ground motion data from containment plugs in the emplacement hole. The LLNL containment program archive includes CDs of digital ground motion data for 189 NTS events between 1977 and 1992. LANL maintain a computerized data base that contains ground motion data for about 150 NTS events, including digitized analog data (App, 1994). The waveform data in both of these archives are unclassified and are available as ASCII or LLNL Seismic Analysis Code (SAC) files. (The yields of most of the tests remain classified.) In addition to the waveforms themselves, instrument calibrations are included in the archives, at least for the mid-1970s onwards. In situ geologic and material property data routinely compiled from the logs for every test emplacement hole are available either as printed reports or computer files. Material properties routinely compiled include P-wave velocity, bulk density and porosity, and water saturations for each lithologic unit. Other material property data were determined for specific units from 


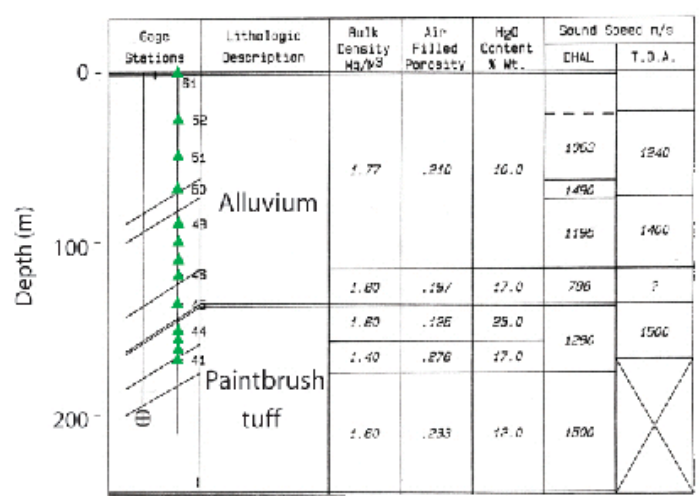

laboratory tests. SNL are in the process of compiling a data base for 17 Rainier Mesa tunnel shots, which includes raw ground motion waveforms in ASCII format and associated calibration and other metadata. We have also located an archive of paper analog records at the DOE Nevada Operations Office in Las Vegas. These are presumably from early tests, but we have not yet examined the record catalogs in detail.

\section{Overview of the Explosion Source}

In order to describe the characteristics of free-field motion recorded in the near-source region, we first provide a brief overview of the explosion source. Figure 3 shows a generalized cartoon of the near-source region within an homogeneous half-space following a nuclear explosion. The rapidly expanding high temperature, high pressure bubble of gas (vaporized rock) created by the detonation creates a shock wave that first melts and then pulverizes the rock immediately surrounding the detonation point to create a cavity, radius $R_{c}$. At a short distance (less than the final cavity radius) from the detonation, the shock wave separates into an elastic precursor traveling at the P-wave speed of the undisturbed medium and the peak pressure pulse that propagates at a subsonic plastic wave speed. The peak stress of the shock wave as it propagates beyond the final cavity radius exceeds the yield shear stress of the rock and creates a zone of macroscopic damage out to a distance of about three cavity radii.

The principal stresses (one radial, two tangential) within this zone are all compressive, and the predominant damage modes are pore compaction and collapse, and shear failure accompanied by dilatation. Damage and plastic yielding within the compaction zone rapidly attenuate the plastic wave such that the peak pressure falls below the yield stress and the tangential principal stresses become tensile on reaching the boundary of the zone, resulting in relatively minor tensile failure out to about five cavity radii. Within this zone the peak stress (main wave)

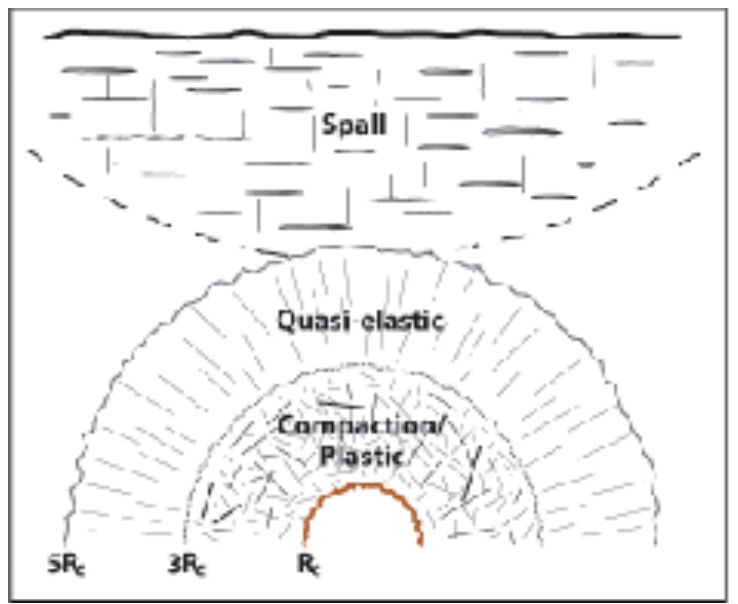

Figure 3: Explosion source propagates at the elastic $\mathrm{P}$-wave speed but it attenuates quasi-elastically. Beyond this wave propagation is essentially elastic, but with minor non-linear behavior at $\sim 10^{-6}$ strain. 
At about the time the shock wave has traversed the compaction zone the cavity wall rebounds, followed by re-expansion and re-compaction and, finally, damped oscillations. These pulses propagate outwards to become later arriving peaks of an elastically propagating wave train beyond the quasi-elastic zone. When the main compressional peak reaches the free surface it is reflected as a tensional wave front that exceeds the tensional strength of the material, resulting in tensional failure, or spall, down to some depth such that near-surface layers actually detach and go ballistic. Table 1 summarizes empirical scaling of magnitude $\left(\mathrm{m}_{\mathrm{b}}\right)$ and $\mathrm{R}_{\mathrm{c}}$ and normal depth of burial with explosive yield, W, in kilotons.

\section{Ground Motion Characteristics}

To illustrate some of the general characteristics of near-source waveforms recorded by free-field arrays we summarize the analysis by Terhune and Heusinkveld (1983) of data recorded on the PERA array shown in Figure 2 and on similar vertical arrays for events NORBO, KARAB and TILCI. All of these tests were conducted under Yucca Flat. The first three were detonated in tuff, and TILCI, in alluvium. Figure 4a shows travel time curves for the main (peak velocity) wave for PERA (P), NORBO (N) and TILCI (T), and for the elastic precursor for $\operatorname{KARAB}(\mathrm{X})$; the detonation depths are indicated on the figure. Close to the source, the main waves propagate at subsonic (plastic) speeds before abruptly accelerating to elastic P-wave speeds similar to the speed of the elastic precursor from $\mathrm{X}$. This transition defines the sharp boundary between the compaction and quasistatic zones (Figure 3), which Terhune and Heusinkveld show is also well defined by the limits of residual volumetric strain derived from the velocity data. Figure $4 \mathrm{~b}$ shows peak velocity as a function of slant range (normalized to PERA) for events $\mathrm{P}, \mathrm{N}$ and $\mathrm{T}$. Out to a normalized range of about $80 \mathrm{~m}$, again corresponding to the perimeter of the compaction zone, the peak velocity attenuates rapidly at $\sim \mathrm{R}^{-3}$, indicative of strong energy dissipation by pore compaction and plastic yielding. At the perimeter of the zone, the attenuation rate abruptly changes to $\sim \mathrm{R}^{-1}$, indicating quasi-elastic behavior. Note that the
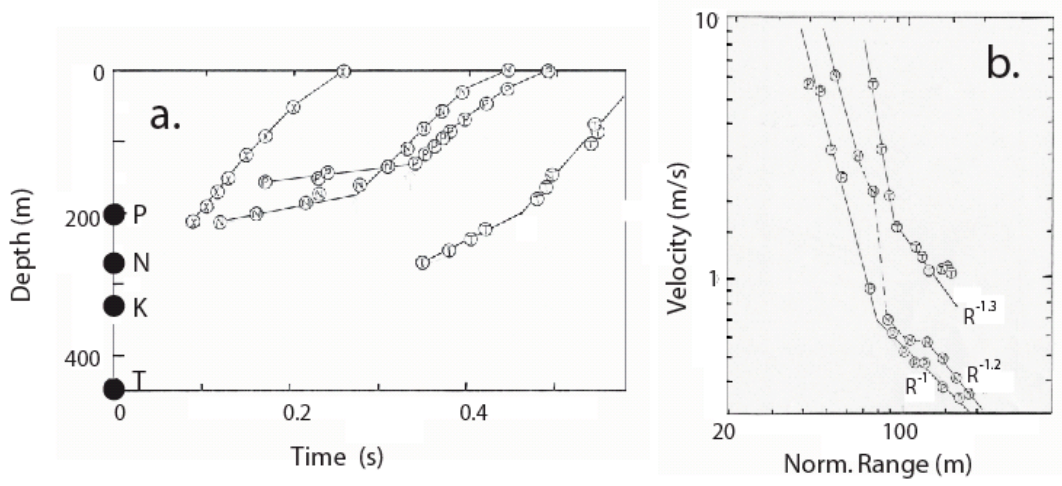
transitions in both velocity and attenuation rate are clearly defined by the data.

Figure 5 shows the velocity waveforms recorded on the four sensors closest to shot NORBO [yield $<20 \mathrm{kt}$ (DOE, 2000)], within

Figure 4: Travel time (a) and attenuation (b) curves the compaction zone (Figure 3). The waveforms are time-shifted to the first (elastic precursor) arrival time at one sensor, and amplitudes $V_{i}$ are normalized such that $V_{i}^{\prime}=V_{i}\left(R_{i} / R_{0}\right)^{\alpha}$, where $R_{i}$ and $R_{0}$ are the slant ranges to sensor $i$ and the reference sensor, respectively, and $\alpha$ is the average of the attenuation rates of the elastic precursor and the main wave across the four sensors. The first, compaction, pulse comprises the elastic precursor (PC) and the peak 
(main) velocity wave (PW), followed by the rebound (negative) and recompaction (positive) pulses and the damped oscillations. The entire wave train propagates inphase across the zone, each of the pulses having a constant duration. The compaction pulse attenuates very rapidly across the zone, but the later pulses attenuate at the same rate as the elastic precursor,

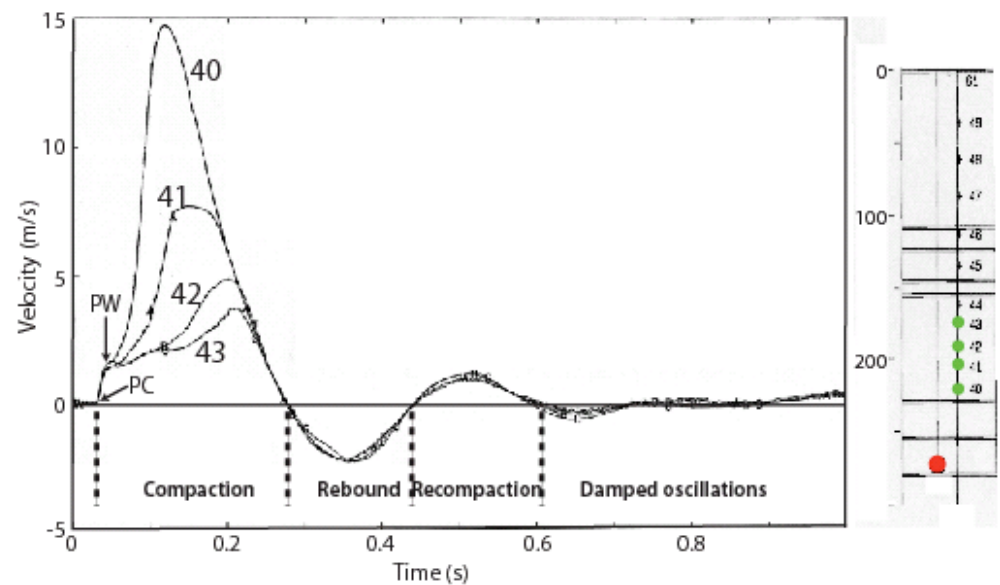

Figure 5: Velocity time histories for four sensors (green) within the compaction zone of event NORBO (red). suggesting quasi-elastic behavior within the compaction zone after the main compaction pulse has passed. Figure 6 shows the PERA [yield $<20 \mathrm{kt}$ (DOE, 2000)] waveforms recorded just outside the compaction zone, where the pulses that developed in the compaction zone are still clearly defined and propagate in-phase at the P-wave speed.

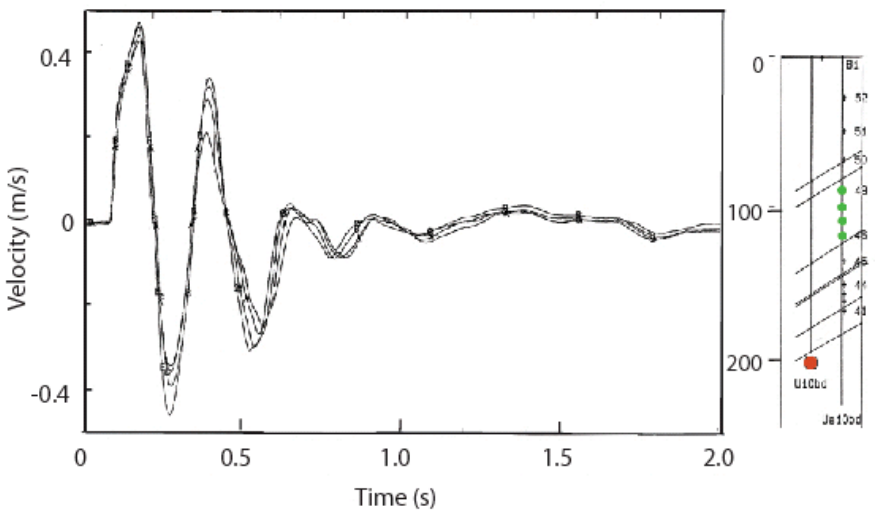

Figure 6: Velocity time histories for four sensors (green) within the quasi-elastic zone of event PERA (red).

The entire wave train attenuates at the same rate as the precursor, so that the overall behavior is quasielastic. Figures 5 and 6 illustrate the general quality of the data recorded on the free-field arrays. We chose these examples because they clearly show the near-source phenomenology. More generally, however, the waveforms are complicated by refractions, reflections and wave conversions from lithological boundaries, which often have strong impedance contrasts in the highly stratified lithologies at NTS.

Figure 6 shows a typical surface accelerogram recorded at a slant range of $1.1 \mathrm{~km}$. The main wave peak acceleration at about $0.5 \mathrm{sec}$ is almost $5 \mathrm{~g}$. This is followed by spall onset at about $0.6 \mathrm{sec}$, and ballistic free-fall $(-1 \mathrm{~g})$ followed by the large slap-down peak at $0.9 \mathrm{sec}$.

\section{Discussion and Conclusions}

The vast amount of ground motion data recorded during the U.S. underground nuclear testing program provides unique insights into material response and wave propagation and attenuation within the near-source regions of seismic events as large as $\sim$ M6. These regions extend from the zone of intense macroscopic damage and highly non-linear 
behavior under high strain and strain rate loading close to the detonation point through the transition to elastic wave propagation to the response of the free-surface, where material response can again becomes non-linear owing to spalling under tensional failure. Much of this data set, together with instrument calibrations and material properties, is available to researchers through the archiving efforts at LLNL, LANL and SNL.

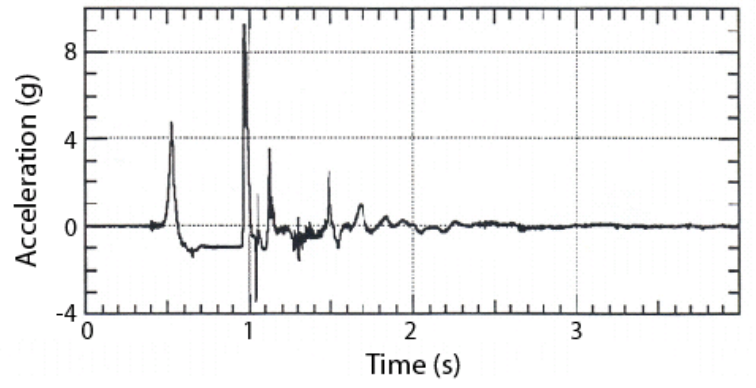

Figure 7: Ground surface vertical acceleration time history at a slant range of $1.1 \mathrm{~km}$ from event $M O L B O$.
The data show that ground motions generated by nuclear explosions are severely attenuated by highly non-linear damage mechanisms and yielding within a few hundred meters of the detonation point, but that the transition to quasielastic and elastic material response is sharp and well defined. Although explosions and earthquakes are quite different seismic sources, this behavior is likely analogous to damage and nonlinear attenuation mechanisms within a

fault zone resulting from dynamic shear rupture that inherently limit the energy that can be propagated elastically. Although shear failure is one of the primary damage mechanisms close to an explosion source, pore compaction under a purely compressive stress regime also predominates in many of the materials at NTS. Therefore, the extent to which explosion data can be applied to the earthquake source should be one of the first topics of research in this field. Irrespective of the loading and damage mechanisms themselves, the ground motion and other data available for NTS have the potential to provide significant insights into the properties of materials analogous to the tuffs at the repository level at Yucca Mountain at high strains and strain rates. One way to achieve this is to use the recorded data to constrain the parameters in dynamic models of wave propagation and damage from selected explosions. This was done extensively as part of the containment programs at the national laboratories, and the data continue to be used to constrain more sophisticated models of explosion effects (e.g. Antoun et al., 1999).

\section{Acknowledgments}

I would like to thank Jeff Wagoner and John Rambo for detective work and assembling the spread sheets, and the LLNL D\&NT Containment program for support. This work was performed under the auspices of the U.S. Department of Energy by University of California, Lawrence Livermore National Laboratory under Contract W-7405-Eng-48.

\section{References}

Antoun, T.H., O.Y. Vorobiev, I.N. Lomov, and L.A. Glenn, Simulations of an underground explosion in granite, American Physical Society Proc. $11^{\text {th }}$ Topical Conference on Shock Compression of Condensed Matter, Snowbird, Utah, Jun 27-Jul 2, 1999. 
App, F.N., The NTS ground motion data base, LAUR-94-1557, Los Alamos National Laboratory, 5 p., 1994.

Terhune, R.W., and M. Heusinkveld, Analysis of near field ground motion from nuclear detonations in high porosity media, Proc. Second Symposium on Containment of Underground Nuclear Explosions, Albuquerque, NM, Aug 2-3, 1983, v. 2, 123-164, 1983.

U.S. Department of Energy, United States nuclear tests, July 1945 through September 1 1992, DOE/NV-209-REV 15, 162 p., 2000. 


\section{Appendix 2 \\ (Attached as excel spreadsheet) \\ Jeffrey L. Wagoner}

This spreadsheet shows the status of strong ground motion measurements for LLNL nuclear explosion events. Most of this information is from the containment library (T1406 Room 1110). 


\begin{tabular}{|c|c|c|c|c|c|c|c|c|}
\hline \multirow{2}{*}{$\begin{array}{l}\text { Event } \\
\text { Ace }\end{array}$} & \multirow{2}{*}{$\begin{array}{l}\text { Hole } \\
\text { U2N }\end{array}$} & \multirow{2}{*}{$\begin{array}{l}\text { Event Date } \\
6 / 11 / 64\end{array}$} & \multirow{2}{*}{$\begin{array}{l}\text { Hole Type } \\
\text { Shaft }\end{array}$} & \multirow{2}{*}{$\begin{array}{l}\text { Yield } \\
<20 \mathrm{kt}\end{array}$} & \multirow{2}{*}{\begin{tabular}{|l} 
Depth of Burial \\
263.35
\end{tabular}} & \multicolumn{2}{|c|}{ Nevada State Plane Coordinates } & \multirow[t]{2}{*}{ Final Reports } \\
\hline & & & & & & North & East & \\
\hline Agile & U2V & $2 / 23 / 67$ & Shaft & 20 to $200 \mathrm{kt}$ & 733.35 & 263865.961 & 205740.445 & \\
\hline Agrini & U2EV & $3 / 31 / 84$ & Shaft & $<20 \mathrm{kt}$ & 320.00 & 266029.887 & 204155.805 & UCRL-ID-128934 (10/97) surface only \\
\hline Ahtanum & U2L & $9 / 13 / 63$ & Shaft & Low & 226.16 & 267910.543 & 204448.139 & \\
\hline Ajax & U9AL & $11 / 11 / 66$ & Shaft & $<20 \mathrm{kt}$ & 239.88 & 264719.342 & 207203.122 & \\
\hline Akavi & U2ES & $12 / 3 / 81$ & Shaft & 20 to $150 \mathrm{kt}$ & 494.00 & 266258.430 & 205328.952 & UCRL-ID-122069 surface only \\
\hline Akbar & U10AX & $11 / 9 / 72$ & Shaft & $<20 \mathrm{kt}$ & 266.70 & 267790.269 & 208666.424 & \\
\hline AKBAR & U9X & $11 / 9 / 72$ & & & & & & \\
\hline Allegheny & U9x & $9 / 29 / 62$ & Shaft & Low & 210.92 & 262756.502 & 208733.410 & \\
\hline Alpaca & U2A & $2 / 12 / 65$ & Shaft & 330 tons & 224.94 & 268041.699 & 204811.059 & \\
\hline Alumroot & U9CJ & $2 / 14 / 73$ & Shaft & $<20 \mathrm{kt}$ & 182.88 & 266121.424 & 207172.886 & \\
\hline $\begin{array}{l}\text { Alva } \\
\text { by aircraft only }\end{array}$ & U2J & $8 / 19 / 64$ & Shaft & $4.4 \mathrm{kt}$ & 166.12 & 267425.992 & 204232.804 & \\
\hline Alviso & U2DU & $6 / 11 / 75$ & Shaft & $<20 \mathrm{kt}$ & 183.00 & 262189.435 & 205100.303 & \\
\hline Anacostia & U9I & $11 / 27 / 62$ & Shaft & Low & 226.77 & 263439.106 & 209063.104 & \\
\hline Antler & U12E.03 & $9 / 15 / 61$ & Tunnel & $2.6 \mathrm{kt}$ & 402.03 & 270577.000 & 193144.000 & \\
\hline Apshapa & U9Al & $6 / 6 / 63$ & Shaft & Low & 89.00 & 263637.333 & 208087.501 & \\
\hline $\begin{array}{l}\text { Arabis-Blue } \\
\text { Simultaneous, } \\
\text { separate holes }\end{array}$ & U9IZ26 & $3 / 6 / 70$ & Shaft & & 100.58 & 265298.481 & 208849.073 & \\
\hline Arabis-Green & U9IX28 & $3 / 6 / 70$ & Shaft & $<20 \mathrm{kt}$ & 258.71 & 265542.291 & 208605.604 & \\
\hline Arabis-Red & U9IV26 & $3 / 6 / 70$ & Shaft & $<20 \mathrm{kt}$ & 249.91 & 265298.518 & 208361.517 & \\
\hline Arikaree & U9R & $5 / 10 / 62$ & Shaft & Low & 166.42 & 263958.020 & 207346.293 & \\
\hline Armada & U9CS & $4 / 22 / 83$ & Shaft & $<20 \mathrm{kt}$ & 265.00 & 262189.598 & 209657.124 & UCOPKL 83 (6/2/83-Stubbs) surface only \\
\hline $\begin{array}{l}\text { Arnica-Violet } \\
\text { Simultaneous, } \\
\text { separate holes }\end{array}$ & U2DD2 & $6 / 26 / 70$ & Shaft & $<20 \mathrm{kt}$ & 263.65 & 262777.768 & 204167.698 & \\
\hline Arnica-Yellow & U2DD3 & $6 / 26 / 70$ & Shaft & $<20 \mathrm{kt}$ & 309.37 & 262421.172 & 203993.925 & \\
\hline Arsenate & $\mathrm{U} 9 \mathrm{Cl}$ & $11 / 9 / 72$ & Shaft & $<20 \mathrm{kt}$ & 250.24 & 263285.840 & 208770.145 & \\
\hline Asco & U10BC & $4 / 25 / 78$ & Shaft & $<20 \mathrm{kt}$ & 183.00 & 266959.651 & 208529.313 & \\
\hline Asiago & U2AR & $12 / 21 / 76$ & Shaft & $<20 \mathrm{kt}$ & 330.70 & 263539.266 & 205646.457 & \\
\hline Avens-Alkermes & U9IU24 & $12 / 16 / 70$ & Shaft & $<20 \mathrm{kt}$ & 306.02 & 265054.839 & 208239.676 & \\
\hline Avens-Andorre & U9IT28 & $12 / 16 / 70$ & Shaft & $<20 \mathrm{kt}$ & 379.48 & 265542.151 & 208117.771 & \\
\hline
\end{tabular}




\begin{tabular}{|c|c|c|c|c|c|c|c|c|}
\hline \multirow{2}{*}{\begin{tabular}{|l} 
Event \\
Avens-Asamlte
\end{tabular}} & \multirow{2}{*}{\begin{tabular}{|l|} 
Hole \\
U9IW21 \\
\end{tabular}} & \multirow{2}{*}{\begin{tabular}{|l|} 
Event Date \\
$12 / 16 / 70$ \\
\end{tabular}} & \multirow{2}{*}{\begin{tabular}{|l|} 
Hole Type \\
Shaft \\
\end{tabular}} & \multirow{2}{*}{$\begin{array}{l}\text { Yield } \\
<20 \mathrm{kt} \\
\end{array}$} & \multirow{2}{*}{\begin{tabular}{|l|} 
Depth of Burial \\
306.32 \\
\end{tabular}} & \multicolumn{2}{|c|}{ Nevada State Plane Coordinates } & \multirow[t]{2}{*}{ Final Reports } \\
\hline & & & & & & 264689.020 & 208483.452 & \\
\hline $\begin{array}{l}\text { Avens-Cream } \\
\text { Simultaneous, } \\
\text { separate holes }\end{array}$ & U9IX29 & $12 / 16 / 70$ & Shaft & $<20 \mathrm{kt}$ & 294.13 & 265664.028 & 208605.708 & \\
\hline $\begin{array}{l}\text { Azul } \\
\text { Detonation } \\
\text { destroyed } \\
\text { Peninsula device } \\
\text { that was damaged } \\
\text { during } \\
\text { emplacement on } \\
10 / 23 / 75 \\
\text { Peninsula device } \\
\text { was not tested } \\
\end{array}$ & U2EM & $12 / 14 / 79$ & Shaft & $<20 \mathrm{kt}$ & 205.00 & 265035.399 & 206026.635 & UCRL-ID-127719 surface only \\
\hline Backswing & U9AW & $5 / 14 / 64$ & Shaft & $<20 \mathrm{kt}$ & 160.63 & 262827.597 & 208184.769 & \\
\hline Baltic & U9IS25 & $8 / 6 / 71$ & Shaft & $<20 \mathrm{kt}$ & 411.48 & 265176.625 & 207995.820 & \\
\hline Baneberry & U8D & $12 / 18 / 70$ & Shaft & $10 \mathrm{kt}$ & 277.98 & 268983.816 & 202823.247 & \\
\hline Banon & U2DZ & $8 / 26 / 76$ & Shaft & 20 to $150 \mathrm{kt}$ & 536.40 & 263652.735 & 204353.727 & \\
\hline Barnwell & U2OAZ & $12 / 8 / 89$ & Shaft & 20 to $150 \mathrm{kt}$ & 600.80 & 275295.911 & 175229.871 & misc-5035 surface only \\
\hline Bellow & U4AC & $5 / 16 / 84$ & Shaft & $<20 \mathrm{kt}$ & 207.30 & 260040.644 & 203378.140 & \\
\hline Belmont & U20AS & $10 / 16 / 86$ & Shaft & 20 to $150 \mathrm{kt}$ & 605.00 & 274077.135 & 170596.627 & UOPKL 87-2 (3/20/87) surface only \\
\hline Benham & U2OC & $12 / 19 / 68$ & Shaft & $1.15 \mathrm{Mt}$ & 1402.08 & 275325.129 & 169534.525 & \\
\hline Biggin & U9BZ & $1 / 30 / 69$ & Shaft & $<20 \mathrm{kt}$ & 243.84 & 264597.098 & 208056.844 & \\
\hline Black & U9P & $4 / 27 / 62$ & Shaft & Low & 217.63 & 262951.251 & 208288.535 & \\
\hline Blanca & U12E.05 & $10 / 30 / 58$ & Tunnel & $22 \mathrm{kt}$ & 301.14 & 270355.000 & 193656.000 & \\
\hline Bodie & U20AP & 12/13/86 & Shaft & 20 to $150 \mathrm{kt}$ & 635.00 & 278831.461 & 175016.718 & UCRL-ID-117558 (6/94) surface only \\
\hline Bogey & U9AU & $4 / 17 / 64$ & Shaft & $<20 \mathrm{kt}$ & 119.18 & 263067.456 & 208632.338 & \\
\hline Borate & U2GE & $10 / 23 / 87$ & Shaft & 20 to $150 \mathrm{kt}$ & 542.50 & 265528.880 & 204635.205 & UCRL-ID-1 17557 (6/94) surface only \\
\hline Bowl-1 & U2BO1 & $6 / 26 / 69$ & Shaft & $<20 \mathrm{kt}$ & 198.12 & 267813.281 & 204627.926 & \\
\hline $\begin{array}{l}\text { Bowl-2 } \\
\text { Simultaneous, } \\
\text { separate holes }\end{array}$ & U2BO2 & $6 / 26 / 69$ & Shaft & $<20 \mathrm{kt}$ & 228.60 & 267624.140 & 204582.157 & \\
\hline Boxcar & U2OI & $4 / 26 / 68$ & Shaft & $1.3 \mathrm{Mt}$ & 1165.86 & 282424.947 & 171104.483 & $\begin{array}{l}\text { surface and FF boreholes (>1KM from GZ), } \\
\text { Perret, } 1968, \text { SC-TM-68-458. }\end{array}$ \\
\hline Bracken & U10AQ & 7/9/71 & Shaft & $<20 \mathrm{kt}$ & 304.80 & 268057.716 & 208702.168 & \\
\hline Branco & U2EW & $9 / 21 / 83$ & Shaft & $<20 \mathrm{kt}$ & 293.00 & 263262.383 & 206703.429 & UCRL-ID-125019 surface only \\
\hline Brazos & U9D & $3 / 8 / 62$ & Shaft & $8.4 \mathrm{kt}$ & 256.34 & 263355.834 & 207298.577 & \\
\hline Breton & U4AR & $9 / 13 / 84$ & Shaft & 20 to $150 \mathrm{kt}$ & 483.00 & 259406.305 & 205341.992 & misc-4685 surface only \\
\hline
\end{tabular}




\begin{tabular}{|c|c|c|c|c|c|c|c|c|}
\hline Event & Hole & Event Date & Hole Type & Yield & Depth of Burial & \multicolumn{2}{|c|}{ Nevada State Plane Coordinates } & Final Reports \\
\hline Brie & U10CC & $6 / 18 / 87$ & Shaft & $<20 \mathrm{kt}$ & 203.00 & 271285.893 & 208478.039 & $\begin{array}{l}\text { UCRL-ID-120651 (3/95) surface and free } \\
\text { field (UE10aa) }\end{array}$ \\
\hline Bristol & U4AV & 11/26/91 & Shaft & $<20 \mathrm{kt}$ & 457.20 & 260494.702 & 205474.321 & Stubbs and others (CDR) surface only \\
\hline Buggy-A & U30A & $3 / 12 / 68$ & Crater & $1.08 \mathrm{kt}$ & 41.15 & 250493.749 & 178805.471 & \\
\hline Buggy-B & U30B & $3 / 12 / 68$ & Crater & $1.08 \mathrm{kt}$ & 41.15 & 250509.900 & 178762.680 & \\
\hline Buggy-C & U30C & $3 / 12 / 68$ & Crater & $1.08 \mathrm{kt}$ & 41.15 & 250526.021 & 178719.862 & \\
\hline Buggy-D & U30D & $3 / 12 / 68$ & Crater & $1.08 \mathrm{kt}$ & 41.15 & 250542.117 & 178677.129 & \\
\hline $\begin{array}{l}\text { Buggy-E } \\
\text { Simultaneous, } \\
\text { separate holes } \\
\text { Row charge } \\
\text { experiment -- five } \\
\text { simultaneous } \\
\text { detonations }\end{array}$ & U30E & $3 / 12 / 68$ & Crater & $1.08 \mathrm{kt}$ & 41.15 & 250558.220 & 178634.353 & \\
\hline Bullfrog & U4AU & $8 / 30 / 88$ & Shaft & $<150 \mathrm{kt}$ & 489.20 & 259324.197 & 205578.843 & misc-4686 surface only \\
\hline Bullion & U2OBD & $6 / 13 / 90$ & Shaft & 20 to $150 \mathrm{kt}$ & 673.90 & 278679.228 & 174269.444 & UCRL-MI-104746 none \\
\hline Bunker & U9BB & $2 / 13 / 64$ & Shaft & $<20 \mathrm{kt}$ & 227.08 & 264458.822 & 208760.986 & \\
\hline Burzet & U4AI & $8 / 3 / 79$ & Shaft & 20 to $150 \mathrm{kt}$ & 450.00 & 259103.406 & 205458.480 & $\begin{array}{l}\text { UCRL-ID-129058 (10/97) surface and free } \\
\text { field (UE4ah) }\end{array}$ \\
\hline Bye & U10I & 7/16/64 & Shaft & 20 to $200 \mathrm{kt}$ & 390.75 & 270020.940 & 207568.813 & \\
\hline Caboc & $\mathrm{U} 2 \mathrm{CP}$ & $12 / 16 / 81$ & Shaft & $<20 \mathrm{kt}$ & 335.00 & 262468.024 & 200727.512 & UCRL-ID-125021 (4/96) surface only \\
\hline Cabra & U20AJ & $3 / 26 / 83$ & Shaft & 20 to $150 \mathrm{kt}$ & 542.50 & 283007.510 & 170718.791 & $\begin{array}{l}\text { UCOPKL 83-41, UCRL-ID-125018 surface } \\
\text { only }\end{array}$ \\
\hline Cabrillo & U2DR & $3 / 7 / 75$ & Shaft & 20 to $200 \mathrm{kt}$ & 600.50 & 264650.707 & 204147.874 & \\
\hline Cabriolet & U2OL & $1 / 26 / 68$ & Crater & $2.3 \mathrm{kt}$ & 51.82 & 280797.491 & 165898.647 & \\
\hline CAERPHILLY & U8E & $9 / 27 / 78$ & & & 420.00 & 268755.024 & 203863.404 & \\
\hline Calabash & U2AV & $10 / 29 / 69$ & Shaft & $110 \mathrm{kt}$ & 624.84 & 265694.813 & 205953.720 & \\
\hline Cambric & U5E & $5 / 14 / 65$ & Shaft & 750 tons & 294.74 & 230252.041 & 214832.970 & \\
\hline Camembert & U19Q & $6 / 26 / 75$ & Shaft & 200 to $1000 \mathrm{kt}$ & 1310.60 & 280614.562 & 178833.909 & \\
\hline Camphor & U12G.10 & $6 / 29 / 71$ & Tunnel & $<20 \mathrm{kt}$ & 423.67 & 269334.956 & 192819.036 & \\
\hline Campos & U9CP & $2 / 13 / 78$ & Shaft & $<20 \mathrm{kt}$ & 320.00 & 263804.769 & 208818.898 & \\
\hline CAN & U2DD4 & $4 / 21 / 70$ & & & 399.29 & 262607.714 & 204525.766 & \\
\hline Can-Green & U2DD1 & $4 / 21 / 70$ & Shaft & 20 to $200 \mathrm{kt}$ & 274.32 & 262250.371 & 204353.648 & \\
\hline CANNA & U9IYZ26 & $11 / 17 / 72$ & & & 213.42 & 265298.466 & 208753.399 & \\
\hline CANNA & U9IYZ26 & $11 / 17 / 72$ & & & 182.88 & 265298.466 & 208753.399 & \\
\hline $\begin{array}{l}\text { Cannikin } \\
\text { Test of warhead } \\
\text { for Spartan missile }\end{array}$ & A1 & $11 / 6 / 71$ & Shaft & $<5 \mathrm{Mt}$ & 1790.70 & -99.900 & -99.900 & $\begin{array}{l}\text { surface stations and free field } \\
\text { measurements in UA- } 1 \text { satellite holes }\end{array}$ \\
\hline Carmel & $\mathrm{U} 2 \mathrm{H}$ & $2 / 21 / 63$ & Shaft & Low & 164.29 & 266960.952 & 204521.258 & \\
\hline
\end{tabular}




\begin{tabular}{|c|c|c|c|c|c|c|c|c|}
\hline Event & Hole & Event Date & Hole Type & Yield & Depth of Burial & \multicolumn{2}{|c|}{ Nevada State Plane Coordinates } & Final Reports \\
\hline Carnelian & U4AF & 7/28/77 & Shaft & $<20 \mathrm{kt}$ & 208.00 & 260604.486 & 203576.400 & UCRL-ID-131332 (7/98) surface only \\
\hline Carpetbag & U2DG & $12 / 17 / 70$ & Shaft & $220 \mathrm{kt}$ & 661.70 & 264109.759 & 204262.253 & \\
\hline Cashmere & U2AD & 2/4/65 & Shaft & $<20 \mathrm{kt}$ & 233.17 & 264300.783 & 206162.426 & \\
\hline Casselman & U10G & $2 / 8 / 63$ & Shaft & Low & 302.97 & 266318.067 & 207013.116 & \\
\hline Cathay & $\mathrm{U} 9 \mathrm{CH}$ & $10 / 8 / 71$ & Shaft & $<20 \mathrm{kt}$ & 377.95 & 262433.340 & 208331.238 & \\
\hline Cebrero & U9CW & $8 / 14 / 85$ & Shaft & $<20 \mathrm{kt}$ & 183.00 & 262146.386 & 210373.043 & UCRL-ID-121262 (5/95) surface only \\
\hline Centaur & U2AK & $8 / 27 / 65$ & Shaft & $<20 \mathrm{kt}$ & 173.74 & 265024.045 & 205404.972 & \\
\hline Chaenactis & U2DL & 12/14/71 & Shaft & 20 to $200 \mathrm{kt}$ & 330.71 & 263530.982 & 203682.788 & \\
\hline Chantilly & U2DI & 9/29/71 & Shaft & $<20 \mathrm{kt}$ & 330.71 & 263591.528 & 203911.711 & \\
\hline Chateaugay & U20T & $6 / 28 / 68$ & Shaft & 20 to $200 \mathrm{kt}$ & 607.23 & 276880.791 & 168707.473 & \\
\hline Chatty & U2BN & $3 / 18 / 69$ & Shaft & $<20 \mathrm{kt}$ & 195.07 & 267791.723 & 204871.334 & \\
\hline Cheedam & U2ET & $2 / 17 / 83$ & Shaft & $<20 \mathrm{kt}$ & 343.00 & 267858.849 & 205984.301 & UCRL-ID-125015 (4/96) surface only \\
\hline Chena & U12B.09 & 10/10/61 & Tunnel & Low & 255.42 & 271279.730 & 193206.885 & \\
\hline Chenille & U9BG & $4 / 22 / 65$ & Shaft & $<20 \mathrm{kt}$ & 140.82 & 262174.695 & 208940.827 & \\
\hline Cheshire & U2ON & $2 / 14 / 76$ & Shaft & 200 to $500 \mathrm{kt}$ & 1167.00 & 276574.186 & 174266.098 & \\
\hline Chevre & U10AY & $11 / 23 / 76$ & Shaft & $<20 \mathrm{kt}$ & 317.00 & 268851.146 & 206926.089 & \\
\hline Chiberta & U2EK & $12 / 20 / 75$ & Shaft & 20 to $200 \mathrm{kt}$ & 716.00 & 263957.288 & 206167.096 & \\
\hline Cimarron & U9H & $2 / 23 / 62$ & Shaft & $11.9 \mathrm{kt}$ & 304.80 & 264098.716 & 207344.650 & \\
\hline Clarksmobile & U2AS & $5 / 17 / 68$ & Shaft & 20 to $200 \mathrm{kt}$ & 472.44 & 263115.316 & 206415.886 & \\
\hline Clearwater & U12Q & $10 / 16 / 63$ & Shaft & & 544.98 & 271701.351 & 191207.982 & \\
\hline Club & U2AA & $1 / 30 / 64$ & Shaft & $<20 \mathrm{kt}$ & 180.75 & 264902.179 & 205353.516 & \\
\hline Clymer & U9CE & $3 / 12 / 66$ & Shaft & $<20 \mathrm{kt}$ & 398.07 & 265740.585 & 206959.529 & \\
\hline Codsaw & U9G & $2 / 19 / 62$ & Shaft & Low & 212.14 & 263949.650 & 208339.669 & \\
\hline Coffer & U2DE & $3 / 21 / 69$ & Shaft & $<100 \mathrm{kt}$ & 464.82 & 264561.303 & 203933.907 & \\
\hline Colby & U20AA & $3 / 14 / 76$ & Shaft & 500 to $1000 \mathrm{kt}$ & 1273.40 & 283594.455 & 169702.662 & \\
\hline Colwick & U20AC & $4 / 26 / 80$ & Shaft & 20 to $150 \mathrm{kt}$ & 633.00 & 277216.493 & 174070.308 & \\
\hline Commodore & U2AM & $5 / 20 / 67$ & Shaft & $250 \mathrm{kt}$ & 745.24 & 264262.202 & 205953.766 & \\
\hline Comstock & U20AY & $6 / 2 / 88$ & Shaft & $<150 \mathrm{kt}$ & 620.30 & 278511.557 & 172410.465 & misc- 4687 surface only \\
\hline Contact & U20AW & $6 / 22 / 89$ & Shaft & 20 to $150 \mathrm{kt}$ & 544.10 & 281041.329 & 174955.514 & misc-4893 surface only \\
\hline Corduroy & U10K & $12 / 3 / 65$ & Shaft & 20 to $200 \mathrm{kt}$ & 678.79 & 268078.336 & 206959.654 & \\
\hline $\begin{array}{l}\text { Cornice-Green } \\
\text { Simultaneous, } \\
\text { separate holes }\end{array}$ & U10AP3 & $5 / 15 / 70$ & Shaft & 20 to $200 \mathrm{kt}$ & 443.48 & 267773.292 & 208160.659 & \\
\hline Cornice-Yellow & U10AP1 & $5 / 15 / 70$ & Shaft & 20 to $200 \mathrm{kt}$ & 390.14 & 268219.873 & 208456.164 & \\
\hline Cornucopia & U2GAS & $7 / 24 / 86$ & Shaft & $<20 \mathrm{kt}$ & 381.00 & 265627.453 & 205308.265 & UCRL-ID-120665 surface only \\
\hline Coso-Bronze & U4AN & $3 / 8 / 91$ & Shaft & $<20 \mathrm{kt}$ & 333.00 & 261366.572 & 205075.998 & UCRL-MI-107445 surface only \\
\hline Coso-Gray & U4AN & $3 / 8 / 91$ & Shaft & $<20 \mathrm{kt}$ & 442.00 & 261366.572 & 205075.998 & \\
\hline
\end{tabular}




\begin{tabular}{|c|c|c|c|c|c|c|c|c|}
\hline Event & Hole & Event Date & Hole Type & Yield & Depth of Burial & Nevada State & Coordinates & Final Reports \\
\hline $\begin{array}{l}\text { Coso-Silver } \\
\text { Simultaneous, } \\
\text { same hole }\end{array}$ & U4AN & $3 / 8 / 91$ & Shaft & $<20 \mathrm{kt}$ & 475.00 & 261366.572 & 205075.998 & \\
\hline Cottage & U8J & $3 / 23 / 85$ & Shaft & 20 to $150 \mathrm{kt}$ & 515.00 & 269748.531 & 203698.162 & \\
\hline Coulommiers & U2EI & 9/27/77 & Shaft & 20 to $150 \mathrm{kt}$ & 530.30 & 266563.516 & 205618.580 & \\
\hline Cremino & U8E & $9 / 27 / 78$ & Shaft & $<20 \mathrm{kt}$ & 210.00 & 268755.024 & 203863.404 & $\begin{array}{l}\text { UCRL-ID-131714 (8/98) surface and free } \\
\text { field (UE8e) }\end{array}$ \\
\hline Crepe & $\mathrm{U} 2 \mathrm{Q}$ & $12 / 5 / 64$ & Shaft & 20 to $200 \mathrm{kt}$ & 403.86 & 262494.209 & 206898.715 & \\
\hline $\begin{array}{l}\text { Crestlake-Briar } \\
\text { Simultaneous, } \\
\text { same hole }\end{array}$ & U2DW & $7 / 18 / 74$ & Shaft & $<20 \mathrm{kt}$ & 373.70 & 263012.477 & 204079.309 & \\
\hline Crestlake-Tansan & U2DW & $7 / 18 / 74$ & Shaft & $<20 \mathrm{kt}$ & 271.61 & 263012.477 & 204079.309 & \\
\hline Crew & U2DB & $11 / 4 / 68$ & Shaft & 20 to $200 \mathrm{kt}$ & 603.50 & 264257.191 & 203949.083 & $\begin{array}{l}\text { UCRL-50867 (9/2/70), free field in } \\
\text { satellite hole UE2b. }\end{array}$ \\
\hline Crew-2nd & U2db & $11 / 4 / 68$ & Shaft & $<20 \mathrm{kt}$ & 359.66 & 264257.191 & 203949.083 & \\
\hline Crock & U10AK & $5 / 8 / 68$ & Shaft & $<20 \mathrm{kt}$ & 181.66 & 267265.759 & 208513.533 & \\
\hline Crowdie & U2FE & $5 / 5 / 83$ & Shaft & $<20 \mathrm{kt}$ & 390.00 & 265938.584 & 203698.202 & $\begin{array}{l}\text { UCRL-ID-122262 (10/95) UOPKL } 83 \\
(7 / 25 / 83) \text { surface only }\end{array}$ \\
\hline Cruet & $\mathrm{U} 2 \mathrm{CN}$ & $10 / 29 / 69$ & Shaft & $11 \mathrm{kt}$ & 263.65 & 263240.970 & 200290.561 & \\
\hline Cumberland & U2E & $4 / 11 / 63$ & Shaft & Low & 226.47 & 267173.182 & 205312.237 & \\
\hline Cup & U9CB & $3 / 26 / 65$ & Shaft & 20 to $200 \mathrm{kt}$ & 538.89 & 266182.132 & 207812.224 & \\
\hline Cyathus & U8B & $3 / 6 / 70$ & Shaft & $8.7 \mathrm{kt}$ & 293.88 & 268986.270 & 203454.431 & \\
\hline Cypress & U12G.09 & $2 / 12 / 69$ & Tunnel & $<20 \mathrm{kt}$ & 411.48 & 268477.457 & 192892.258 & \\
\hline Danablu & U2EU & $6 / 9 / 83$ & Shaft & $<20 \mathrm{kt}$ & 320.00 & 267267.402 & 203689.021 & \\
\hline $\begin{array}{l}\text { Danny Boy } \\
\text { DoD Test } \\
\text { Crater diameter } \\
265 \mathrm{ft} \text {., depth } 84 \\
\mathrm{ft} \text {. in basalt }\end{array}$ & U18A & $3 / 5 / 62$ & Crater & 430 tons & 33.53 & 261986.981 & 179215.553 & \\
\hline Darwin & U20AQ & $6 / 25 / 86$ & Shaft & 20 to $150 \mathrm{kt}$ & 549.00 & 278994.636 & 167244.247 & \\
\hline Dauphin & U9CQ & $11 / 14 / 80$ & Shaft & $<20 \mathrm{kt}$ & 320.00 & 262189.543 & 209992.316 & UCRL-ID-127714 (6/97) surface only \\
\hline Dead & U9K & $4 / 21 / 62$ & Shaft & Low & 193.55 & 263015.482 & 208843.163 & \\
\hline Delamar & U20AT & $4 / 18 / 87$ & Shaft & 20 to $150 \mathrm{kt}$ & 544.10 & 277139.985 & 166375.322 & $\begin{array}{l}\text { HARDIN Sat hole (U20av-1I), FF meas., } \\
\text { UCID-21151. }\end{array}$ \\
\hline Delphinium & |U2DP & |9/26/72 & Shaft & $15 \mathrm{kt}$ & |295.66 & |263247.207 & |204024.305 & \\
\hline Des Moines & U12J.01 & $6 / 13 / 62$ & Tunnel & $2.9 \mathrm{kt}$ & 201.17 & 274400.000 & 197175.000 & \\
\hline $\begin{array}{l}\text { Diablo Hawk } \\
\text { DoD Test }\end{array}$ & U12N.10A & $9 / 13 / 78$ & Tunnel & $<20 \mathrm{kt}$ & 388.00 & 272888.281 & 192866.106 & \\
\hline $\begin{array}{l}\text { Diagonal Line } \\
\text { DoD Test } \\
\text { by aircraft only }\end{array}$ & U11G & $11 / 24 / 71$ & Shaft & $<20 \mathrm{kt}$ & 264.26 & 236470.174 & 217651.751 & \\
\hline
\end{tabular}


Ground Motion Appendix 2 (Jeffrey Wagoner)

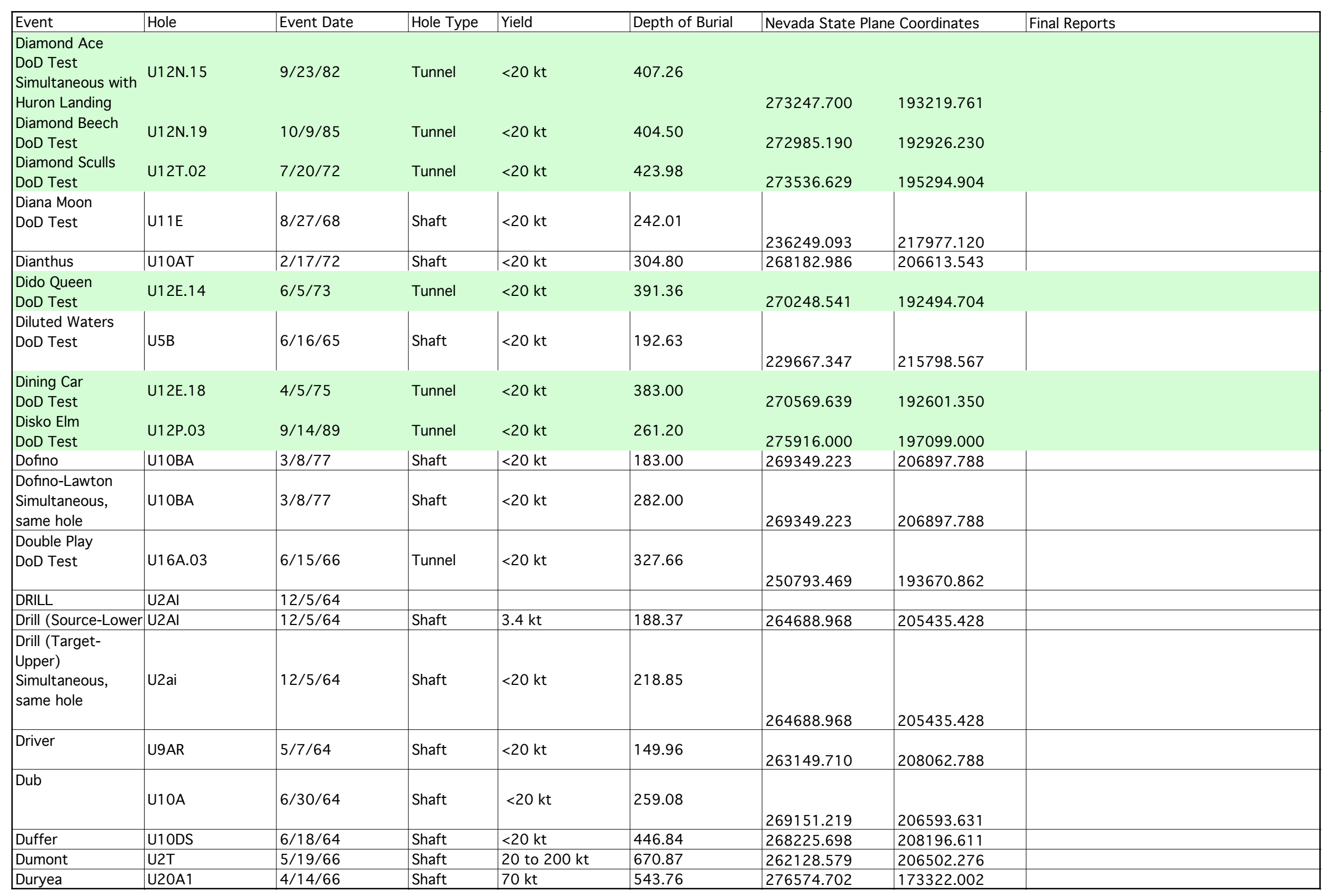




\begin{tabular}{|c|c|c|c|c|c|c|c|c|}
\hline \multirow{2}{*}{$\begin{array}{l}\text { Event } \\
\text { Eagle }\end{array}$} & \multirow{2}{*}{\begin{tabular}{|l|} 
Hole \\
U9AV
\end{tabular}} & \multirow{2}{*}{\begin{tabular}{|l|} 
Event Date \\
$12 / 12 / 63$ \\
\end{tabular}} & \multirow{2}{*}{\begin{tabular}{|l|} 
Hole Type \\
Shaft
\end{tabular}} & \multirow{2}{*}{$\begin{array}{l}\text { Yield } \\
5.3 \mathrm{kt}\end{array}$} & \multirow{2}{*}{\begin{tabular}{|l|} 
Depth of Burial \\
164.90 \\
\end{tabular}} & \multicolumn{2}{|c|}{ Nevada State Plane Coordinates } & \multirow[t]{2}{*}{ Final Reports } \\
\hline & & & & & & 264341.233 & 207736.542 & \\
\hline Edam & U2DY & $4 / 24 / 75$ & Shaft & 20 to $200 \mathrm{kt}$ & 411.50 & 262615.605 & 203880.915 & \\
\hline Eel & U9M & $5 / 19 / 62$ & Shaft & $4.5 \mathrm{kt}$ & 217.63 & 263409.275 & 207446.630 & \\
\hline Effendi & U2AP & $4 / 27 / 67$ & Shaft & $<20 \mathrm{kt}$ & 220.98 & 265191.679 & 206014.260 & \\
\hline Egmont & U20AL & $12 / 9 / 84$ & Shaft & 20 to $150 \mathrm{kt}$ & 546.00 & 279604.130 & 167396.422 & \\
\hline Elkhart & U9BS & $9 / 17 / 65$ & Shaft & $<20 \mathrm{kt}$ & 220.37 & 262128.576 & 208574.908 & \\
\hline Emerson & U2AL & $12 / 16 / 65$ & Shaft & $<20 \mathrm{kt}$ & 260.60 & 265420.054 & 206014.759 & \\
\hline Emmenthal & U19T & $11 / 2 / 78$ & Shaft & $<20 \mathrm{kt}$ & 576.10 & 281637.574 & 185134.126 & \\
\hline Esrom & U7AK & $2 / 4 / 76$ & Shaft & 20 to $200 \mathrm{kt}$ & 655.30 & 261634.811 & 208327.910 & \\
\hline \multicolumn{9}{|l|}{ Evans } \\
\hline Venting & U12B.04 & $10 / 29 / 58$ & Tunnel & 55 tons & 256.03 & & & \\
\hline & & & & & & 271340.000 & 193408.000 & \\
\hline event & location & date & & & dob & & & comments \\
\hline Event X & & & & & & & & UCRL-89408 \\
\hline Fade & U9BE & $6 / 25 / 64$ & Shaft & $<20 \mathrm{kt}$ & 205.13 & 262143.813 & 209093.255 & \\
\hline Fajy & U2FC & $6 / 28 / 79$ & Shaft & 20 to $150 \mathrm{kt}$ & 536.00 & 265664.465 & 203850.992 & \\
\hline Fallon & U2DV & $5 / 23 / 74$ & Shaft & 20 to $200 \mathrm{kt}$ & 466.34 & 263597.636 & 204630.913 & \\
\hline Farallones & U2FA & $12 / 14 / 77$ & Shaft & 20 to $150 \mathrm{kt}$ & 668.00 & 264856.017 & 203987.988 & \\
\hline Farm & U2OAB & $12 / 16 / 78$ & Shaft & 20 to $150 \mathrm{kt}$ & 689.00 & 279989.660 & 175138.372 & $\begin{array}{l}\text { UCRL-ID-128957 (10/97) UOPKL 79-64 } \\
(9 / 17 / 79) \text { surface only }\end{array}$ \\
\hline $\begin{array}{l}\text { Faultless } \\
\text { Seismic calibration }\end{array}$ & C1 & $1 / 19 / 68$ & Shaft & 200 to $1000 \mathrm{kt}$ & 975.36 & 431091.667 & 191695.465 & \\
\hline Feather & U12B.08 & $12 / 22 / 61$ & Tunnel & 150 tons & 247.50 & 271350.504 & 193093.829 & \\
\hline $\begin{array}{l}\text { Fenton } \\
\text { by aircraft only }\end{array}$ & U2M1 & $4 / 23 / 66$ & Shaft & $1.4 \mathrm{kt}$ & 167.34 & 267595.111 & 204251.771 & \\
\hline Flask-Green & U2AZ1 & $5 / 26 / 70$ & Shaft & $105 \mathrm{kt}$ & 528.52 & 262372.075 & 206109.360 & \\
\hline $\begin{array}{l}\text { Flask-Red } \\
\text { Simultaneous, } \\
\text { separate holes }\end{array}$ & U2AZ3 & $5 / 26 / 70$ & Shaft & $<20 \mathrm{kt}$ & 152.40 & 262683.292 & 205719.060 & \\
\hline FLAX & U2DJ & $12 / 21 / 72$ & & & 688.30 & 265310.935 & 204231.901 & $\begin{array}{l}\text { CONF-930910302, FF-UE2dj Rambo } \\
\text { paper. }\end{array}$ \\
\hline Flotost & U2AO & $8 / 16 / 77$ & Shaft & $<20 \mathrm{kt}$ & 275.00 & 266072.684 & 206016.463 & \\
\hline $\begin{array}{l}\text { Fob-Blue } \\
\text { Simultaneous, } \\
\text { separate holes }\end{array}$ & U9IY27 & $1 / 23 / 70$ & Shaft & $<20 \mathrm{kt}$ & 100.58 & 265420.188 & 208727.771 & \\
\hline Fob-Green & U9IV27 & $1 / 23 / 70$ & Shaft & $<20 \mathrm{kt}$ & 244.45 & 265420.508 & 208361.484 & \\
\hline Fob-Red & U9IV24 & $1 / 23 / 70$ & Shaft & $<20 \mathrm{kt}$ & 265.79 & 265054.909 & 208361.468 & \\
\hline
\end{tabular}




\begin{tabular}{|c|c|c|c|c|c|c|c|c|}
\hline Event & Hole & Event Date & Hole Type & Yield & Depth of Burial & \multicolumn{2}{|c|}{ Nevada State Plane Coordinates } & Final Reports \\
\hline Fondutta & U19ZS & $4 / 11 / 78$ & Shaft & 20 to $150 \mathrm{kt}$ & 633.00 & 282924.095 & 182539.818 & \\
\hline Fontina & U20F & $2 / 12 / 76$ & Shaft & 200 to $1000 \mathrm{kt}$ & 1219.00 & 279753.647 & 168206.380 & \\
\hline Fore & U9AO & $1 / 16 / 64$ & Shaft & 20 to $200 \mathrm{kt}$ & 491.03 & 265588.057 & 207264.256 & \\
\hline Forest & U7A & $10 / 31 / 64$ & Shaft & $<20 \mathrm{kt}$ & 386.79 & 261706.159 & 208788.073 & \\
\hline Frisco & U8M & $9 / 23 / 82$ & Shaft & 20 to $150 \mathrm{kt}$ & 451.00 & 269169.391 & 203804.995 & UCRL-ID-125016 (3/96) surface only \\
\hline $\begin{array}{l}\text { Galena-Green } \\
\text { Simultaneous, } \\
\text { same hole }\end{array}$ & U9CV & $6 / 23 / 92$ & Shaft & $<20 \mathrm{kt}$ & 401.00 & 263561.063 & 208864.627 & UCRL-MI-111644 surface only \\
\hline Garden & U9AJ & $10 / 23 / 64$ & Shaft & $<20 \mathrm{kt}$ & 149.66 & 262797.092 & 208878.142 & \\
\hline $\begin{array}{l}\text { Gasbuggy } \\
\text { Joint } \\
\text { Government/indus } \\
\text { try gas stimulation } \\
\text { experiment }\end{array}$ & ONMRIO & $12 / 10 / 67$ & Shaft & $29 \mathrm{kt}$ & 1292.35 & -99.900 & -99.900 & \\
\hline Gazook & U2DO & $3 / 23 / 73$ & Shaft & $<20 \mathrm{kt}$ & 326.14 & 262791.402 & 203911.547 & \\
\hline Gibne & U2OAH & $4 / 25 / 82$ & Shaft & 20 to $150 \mathrm{kt}$ & 570.00 & 278038.952 & 174071.756 & \\
\hline $\begin{array}{l}\text { Gnome } \\
\text { Multiple-purpose } \\
\text { experiment in salt } \\
\text { Formed cavity } \\
160-170 \mathrm{ft} . \\
\text { diameter, } 60-80 \\
\mathrm{ft} \text {. high }\end{array}$ & ONMEDY & $12 / 10 / 61$ & Shaft & $3 \mathrm{kt}$ & 360.88 & -99.900 & -99.900 & BSSA, $12 / 62$ \\
\hline Goldstone & U20AO & $12 / 28 / 85$ & Shaft & 20 to $150 \mathrm{kt}$ & 549.00 & 276027.490 & 169606.339 & \\
\hline Gorbea & U2CQ & $1 / 31 / 84$ & Shaft & 20 to $150 \mathrm{kt}$ & 388.00 & 262265.630 & 200833.296 & \\
\hline Gouda & U2EF & $10 / 6 / 76$ & Shaft & $<20 \mathrm{kt}$ & 200.00 & 264724.020 & 206099.573 & \\
\hline Gourd-Amber & U2BF & 4/24/69 & Shaft & $<20 \mathrm{kt}$ & 181.30 & 267977.745 & 204536.306 & \\
\hline $\begin{array}{l}\text { Gourd-Brown } \\
\text { Simultaneous, } \\
\text { separate holes }\end{array}$ & U2BL & $4 / 24 / 69$ & Shaft & $<20 \mathrm{kt}$ & 226.80 & 267532.462 & 204429.824 & \\
\hline GRADINO & U9CG & $8 / 16 / 77$ & & & 320.00 & 265908.037 & 207264.335 & \\
\hline Greeley & U20G & $12 / 20 / 66$ & Shaft & $870 \mathrm{kt}$ & 1216.46 & 283172.980 & 175305.501 & Surface stations, HN-20-1028 (1969). \\
\hline Greys & U9AX & $11 / 22 / 63$ & Shaft & Intermediate & 301.14 & 263042.633 & 207630.197 & \\
\hline Grove & U2DS & $5 / 22 / 74$ & Shaft & $<20 \mathrm{kt}$ & 313.94 & 262524.838 & 205008.899 & \\
\hline Gruyere & U9CG & $8 / 16 / 77$ & Shaft & $<20 \mathrm{kt}$ & 207.00 & 265908.037 & 207264.335 & \\
\hline $\begin{array}{l}\text { Gum Drop } \\
\text { DoD Test }\end{array}$ & U16A.02 & $4 / 21 / 65$ & Tunnel & $<20 \mathrm{kt}$ & 304.80 & 250516.240 & 193747.162 & \\
\hline Halfbeak & $\mathrm{U} 19 \mathrm{~b}$ & $6 / 30 / 66$ & & $365 \mathrm{kt}$ & & & & Surface stations, HN-20-1028 (1969). \\
\hline
\end{tabular}




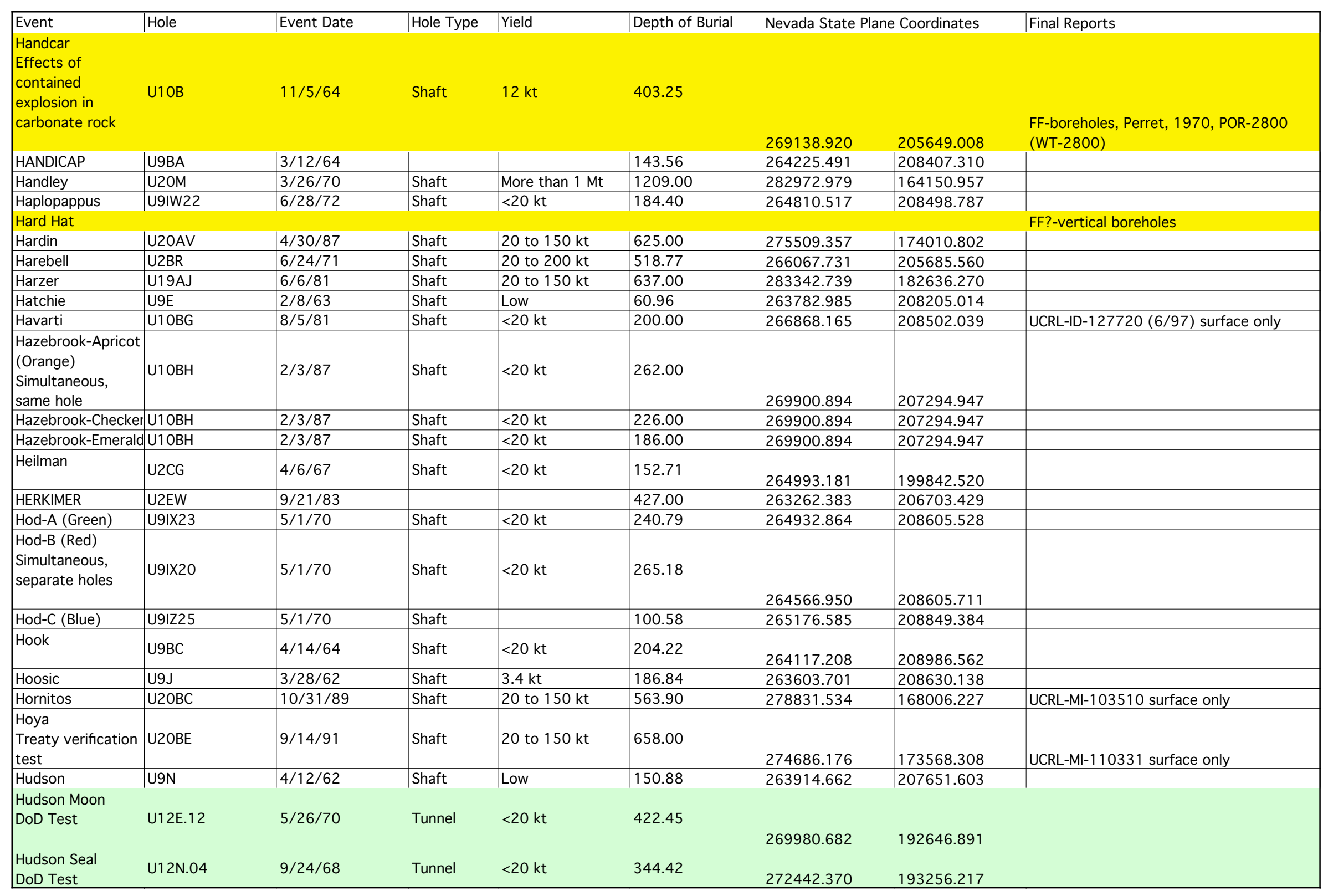




\begin{tabular}{|c|c|c|c|c|c|c|c|c|}
\hline \multirow{2}{*}{$\begin{array}{l}\text { Event } \\
\text { Hula }\end{array}$} & \multirow{2}{*}{\begin{tabular}{|l} 
Hole \\
U9BU
\end{tabular}} & \multirow{2}{*}{\begin{tabular}{|l} 
Event Date \\
$10 / 29 / 68$
\end{tabular}} & \multirow{2}{*}{\begin{tabular}{|l} 
Hole Type \\
Shaft
\end{tabular}} & \multirow{2}{*}{\begin{tabular}{|l|} 
Yield \\
$<20 \mathrm{kt}$
\end{tabular}} & \multirow{2}{*}{\begin{tabular}{|l|} 
Depth of Burial \\
200.56
\end{tabular}} & \multicolumn{2}{|c|}{ Nevada State Plane Coordinates } & \multirow[t]{2}{*}{ Final Reports } \\
\hline & & & & & & 262372.267 & 208011.200 & \\
\hline Hulsea & U2BX & $3 / 14 / 74$ & Shaft & $<20 \mathrm{kt}$ & 195.01 & 267005.401 & 205923.383 & \\
\hline $\begin{array}{l}\text { Hunters Trophy } \\
\text { DoD test to } \\
\text { ensure reliability of } \\
\text { U.S. deterrent } \\
\text { forces }\end{array}$ & U12N.24 & $9 / 18 / 92$ & Tunnel & $<20 \mathrm{kt}$ & 385.30 & 272680.600 & 192937.171 & \\
\hline Hupmobile & $\mathrm{U} 2 \mathrm{Y}$ & $1 / 18 / 68$ & Shaft & $7.4 \mathrm{kt}$ & 246.89 & 265945.030 & 205789.469 & \\
\hline \multicolumn{9}{|l|}{ Huron Landing } \\
\hline $\begin{array}{l}\text { DoD Test } \\
\text { Simultaneous with }\end{array}$ & U12N.15 & $9 / 23 / 82$ & Tunnel & $<20 \mathrm{kt}$ & 408.54 & & & \\
\hline Diamond Ace & & & & & & 273247.700 & 193219.761 & \\
\hline $\begin{array}{l}\text { Husky Pup } \\
\text { DoD Test }\end{array}$ & U12T.03 & $10 / 24 / 75$ & Tunnel & $<20 \mathrm{kt}$ & 348.00 & 274326.563 & 195617.751 & \\
\hline Hutch & |U2DF & |7/16/69 & Shaft & 20 to $200 \mathrm{kt}$ & | 548.64 & |265259.570 & |203860.182 & \\
\hline $\begin{array}{l}\text { Hybla Fair } \\
\text { DoD Test }\end{array}$ & U12N.09 & $10 / 28 / 74$ & Tunnel & $<20 \mathrm{kt}$ & 404.01 & 272041.000 & 193476.000 & \\
\hline Ildrim & U2AU & 7/16/69 & Shaft & 20 to $200 \mathrm{kt}$ & 410.26 & 263049.123 & 206746.196 & \\
\hline IMP & U2BJ & $8 / 9 / 68$ & & & 182.88 & 267736.764 & 204755.811 & \\
\hline Ingot & U2GG & $3 / 9 / 89$ & Shaft & 20 to $150 \mathrm{kt}$ & 500.00 & 265639.748 & 205679.494 & misc-4804 surface only \\
\hline Islay & U2ER & $8 / 27 / 81$ & Shaft & $<20 \mathrm{kt}$ & 294.00 & 267590.588 & 205703.860 & UCRL-ID-127718 (6/97) surface only \\
\hline Izzer & U9BP & $7 / 16 / 65$ & Shaft & $<20 \mathrm{kt}$ & 163.68 & 262570.622 & 208788.543 & \\
\hline Jarlsberg & U10CA & $8 / 27 / 83$ & Shaft & $<20 \mathrm{kt}$ & 200.00 & 271218.215 & 208564.975 & $\begin{array}{l}\text { UCRL-ID-119561 surface and free field } \\
\text { (UE10aa) } 12 / 94\end{array}$ \\
\hline Jefferson & U20Al & $4 / 22 / 86$ & Shaft & 20 to $150 \mathrm{kt}$ & 609.00 & 278953.579 & 172486.809 & UCRL-ID-119478 (12/94) surface only \\
\hline Jorum & U2OE & $9 / 16 / 69$ & Shaft & $<1 \mathrm{Mt}$ & 1160.89 & 284501.041 & 170657.931 & \\
\hline Kankakee & U10P & $6 / 15 / 66$ & Shaft & 20 to $200 \mathrm{kt}$ & 454.76 & 268834.321 & 207263.646 & \\
\hline Kappeli & U20AM & $7 / 25 / 84$ & Shaft & 20 to $150 \mathrm{kt}$ & 640.00 & 279365.145 & 175107.743 & \\
\hline Kara & U2DH3 & $5 / 11 / 72$ & Shaft & $<20 \mathrm{kt}$ & 259.08 & 262262.701 & 204140.105 & \\
\hline Karab & $\mathrm{U} 4 \mathrm{AH}$ & $3 / 16 / 78$ & Shaft & $<20 \mathrm{kt}$ & 331.00 & 259232.626 & 204414.675 & $\begin{array}{l}\text { UCRL-ID-131648 surface and free field } \\
\text { (UE4ad), memo from Stubbs to Hudson } \\
(1 / 10 / 83) \text { UOPKL } 83-6 \text { free field velocity } \\
\text { records }\end{array}$ \\
\hline Kash & U20AF & $6 / 12 / 80$ & Shaft & 20 to $150 \mathrm{kt}$ & 645.00 & 280897.177 & 171271.748 & \\
\hline Kashan & U10AV & $5 / 24 / 73$ & Shaft & $<20 \mathrm{kt}$ & 265.18 & 267797.749 & 206639.625 & \\
\hline Kasseri & U2OZ & $10 / 28 / 75$ & Shaft & 200 to $1000 \mathrm{kt}$ & 1265.00 & 281837.810 & 175020.722 & \\
\hline Kaweah & U9AB & $2 / 21 / 63$ & Shaft & Low & 227.08 & 263152.538 & 207581.255 & \\
\hline KAWICH & U8N & $12 / 9 / 88$ & & & & & & misc-4803 surface only \\
\hline $\begin{array}{l}\text { Kawich A-Blue } \\
\text { Simultaneous, } \\
\text { same hole }\end{array}$ & U8n & $12 / 9 / 88$ & Shaft & $<20 \mathrm{kt}$ & 384.00 & 269230.379 & 203454.468 & UCRL-ID 120477 (8/94) none \\
\hline
\end{tabular}




\begin{tabular}{|c|c|c|c|c|c|c|c|c|}
\hline Event & Hole & Event Date & Hole Type & Yield & Depth of Burial & \multicolumn{2}{|c|}{ Nevada State Plane Coordinates } & Final Reports \\
\hline Kearsarge & U19AX & $8 / 17 / 88$ & Shaft & 100 to $150 \mathrm{kt}$ & 615.70 & 282656.660 & 184328.349 & misc-4718 surface only \\
\hline Kennebec & U2AF & $6 / 25 / 63$ & Shaft & Low & 226.16 & 264369.656 & 205587.316 & \\
\hline Kermet & U2C & $11 / 23 / 65$ & Shaft & $<20 \mathrm{kt}$ & 196.29 & 267752.138 & 205312.523 & \\
\hline Kernville & U20AR & $2 / 15 / 88$ & Shaft & 20 to $150 \mathrm{kt}$ & 541.60 & 284531.369 & 169700.666 & \\
\hline Kesti & U9CN & $6 / 16 / 82$ & Shaft & $<20 \mathrm{kt}$ & 289.00 & 262494.230 & 210175.096 & UCRL-ID-125017 surface only \\
\hline Klickitat & U10E & $2 / 20 / 64$ & Shaft & 20 to $200 \mathrm{kt}$ & 492.56 & 266548.039 & 208056.728 & \\
\hline Kloster & U2EO & $2 / 15 / 79$ & Shaft & 20 to $150 \mathrm{kt}$ & 536.40 & 266654.792 & 205237.884 & \\
\hline Knickerbocker & U20D & $5 / 26 / 67$ & Shaft & $76 \mathrm{kt}$ & 630.63 & 277151.058 & 168944.766 & \\
\hline Knox & U2AT & $2 / 21 / 68$ & Shaft & 20 to $200 \mathrm{kt}$ & 644.80 & 262730.868 & 206874.532 & \\
\hline $\begin{array}{l}\text { Kohocton } \\
\text { Simultaneous, } \\
\text { separate holes }\end{array}$ & U9AK & $8 / 23 / 63$ & Shaft & Low & 254.81 & 263674.211 & 208495.407 & \\
\hline Kootanai & U9W & $4 / 24 / 63$ & Shaft & Low & 181.97 & 263189.249 & 208419.499 & \\
\hline KRYDDOST & U2CO & $5 / 6 / 82$ & & & 335.00 & 262722.834 & 200368.328 & $\begin{array}{l}\text { UCRL-ID-121261 (9/95) surface and free } \\
\text { field UE2co) }\end{array}$ \\
\hline Kyack-A & U2BQ1 & $9 / 20 / 69$ & Shaft & $<20 \mathrm{kt}$ & 185.93 & 267404.708 & 205598.082 & \\
\hline $\begin{array}{l}\text { Kyack-B } \\
\text { Simultaneous, } \\
\text { separate holes }\end{array}$ & U2BQ2 & $9 / 20 / 69$ & Shaft & $<20 \mathrm{kt}$ & 192.02 & 267258.379 & 205737.278 & \\
\hline Laban & U2FF & $8 / 3 / 83$ & Shaft & $<20 \mathrm{kt}$ & 326.00 & 262981.911 & 203743.995 & UCRL-ID-121264 (5/95) surface only \\
\hline Labis & U10AN & $2 / 5 / 70$ & Shaft & $25 \mathrm{kt}$ & 441.96 & 267999.944 & 208160.812 & \\
\hline Labquark & U19AN & $9 / 30 / 86$ & Shaft & 20 to $150 \mathrm{kt}$ & 616.00 & 282980.849 & 184248.311 & UCRL-ID-121260 (5/95) surface only \\
\hline Lagoon & U10AR & $10 / 14 / 71$ & Shaft & $<20 \mathrm{kt}$ & 304.80 & 269747.055 & 206883.005 & \\
\hline Lanpher & $\mathrm{U} 2 \mathrm{X}$ & $10 / 18 / 67$ & Shaft & 20 to $200 \mathrm{kt}$ & 715.06 & 262620.668 & 206525.371 & \\
\hline LARKIN & U10BB & $2 / 6 / 75$ & & & 274.30 & 269595.481 & 207020.458 & \\
\hline Lexington & U2BM & $8 / 24 / 67$ & Shaft & $<20 \mathrm{kt}$ & 226.47 & 267843.289 & 205023.972 & \\
\hline Leyden & U9CM & $11 / 26 / 75$ & Shaft & $<20 \mathrm{kt}$ & 326.10 & 262829.481 & 209967.914 & \\
\hline Links & U9BF & $7 / 23 / 64$ & Shaft & $<20 \mathrm{kt}$ & 120.40 & 262433.157 & 208803.591 & \\
\hline Liptauer & U2eh & $4 / 3 / 80$ & Shaft & 20 to $150 \mathrm{kt}$ & 417.00 & 266412.177 & 204313.295 & \\
\hline Logan & U12E.02 & $10 / 16 / 58$ & Tunnel & $5 \mathrm{kt}$ & 283.46 & 270145.000 & 193731.000 & \\
\hline Longchamps & U2DM & 4/19/72 & Shaft & $\mid<20 \mathrm{kt}$ & 326.44 & 263311.169 & 204192.268 & \\
\hline Mad & U9A & $12 / 13 / 61$ & Shaft & 500 tons & 181.66 & 263848.414 & 207306.047 & \\
\hline Madison & U12G.01 & $12 / 12 / 62$ & Tunnel & Low & 402.34 & 268829.000 & 193670.000 & \\
\hline Manatee & U9AF & 12/14/62 & Shaft & Low & 59.74 & 263591.494 & 208089.705 & \\
\hline Manteca & U4AL & $12 / 10 / 82$ & Shaft & 20 to $150 \mathrm{kt}$ & 413.00 & 258684.336 & 205283.138 & $\begin{array}{l}\text { UOPKL 83-19 (2/9/83), UCRL-ID-125014 } \\
\text { (4/96) surface only }\end{array}$ \\
\hline
\end{tabular}




\begin{tabular}{|c|c|c|c|c|c|c|c|c|}
\hline Event & Hole & Event Date & Hole Type & Yield & Depth of Burial & Nevada State & Coordinates & Final Reports \\
\hline Maribo & U2CS & $6 / 26 / 85$ & Shaft & $<20 \mathrm{kt}$ & 381.00 & 263530.729 & 200800.691 & UCRL-ID-121266 (5/95) surface only \\
\hline Mars & & & & & & & & \\
\hline & U12D & $9 / 28 / 58$ & Tunnel & 13 tons & 38.10 & & & \\
\hline & & & & & & 271146.000 & 193792.000 & \\
\hline $\begin{array}{l}\text { Marshmallow } \\
\text { DoD Test }\end{array}$ & U16A & $6 / 28 / 62$ & Tunnel & Low & 310.90 & 250732.538 & 193838.335 & \\
\hline Marsilly & U2EL & $4 / 5 / 77$ & Shaft & 20 to $150 \mathrm{kt}$ & 690.00 & 263134.427 & 206106.133 & \\
\hline $\begin{array}{l}\text { Marvel } \\
\text { Emplacement } \\
\text { technique } \\
\text { experiment }\end{array}$ & U10DS1 & $9 / 21 / 67$ & Shaft & $2.2 \mathrm{kt}$ & 175.87 & 268228.182 & 208196.248 & \\
\hline Maxwell & U9BR & $1 / 13 / 66$ & Shaft & $<20 \mathrm{kt}$ & 182.88 & 262707.929 & 209199.865 & \\
\hline Mercury & U12F.01 & $9 / 23 / 58$ & Tunnel & Slight & 55.78 & -99.900 & -99.900 & \\
\hline Merida & U2DN & |6/7/72 & Shaft & |<20 kt & |204.22 & 262639.050 & 204064.148 & \\
\hline Merlin & U3ct & $2 / 16 / 65$ & & $10.1 \mathrm{kt}$ & 296 & & & $\begin{array}{l}\text { FF boreholes, SC-RR-69-334 (Perret, } \\
\text { 1971). }\end{array}$ \\
\hline Merrimac & U3BD & $7 / 13 / 62$ & Shaft & Intermediate & 413.31 & 255918.983 & 208724.416 & \\
\hline Metropolis & $3 / 10 / 90$ & & & & & & & UCRL-MI-104930 surface only \\
\hline Mickey & U2GH & $5 / 10 / 67$ & Shaft & 20 to $200 \mathrm{kt}$ & 469.40 & 262280.338 & 206745.939 & \\
\hline $\begin{array}{l}\text { Middle Note } \\
\text { DoD Test }\end{array}$ & U12N.21 & $3 / 18 / 87$ & Tunnel & $<20 \mathrm{kt}$ & 398.70 & 273048.921 & 193060.706 & \\
\hline MIDIMIST & U12N.02 & $6 / 26 / 67$ & & & 377.04 & 272146.982 & 193130.761 & \\
\hline Miera & U7ad & $3 / 8 / 73$ & Shaft & 20 to $200 \mathrm{kt}$ & 398.00 & 272916.412 & | 192716.382 & \\
\hline $\begin{array}{l}\text { Mighty Epic } \\
\text { DoD Test }\end{array}$ & U12N.10 & $5 / 12 / 76$ & Tunnel & $<20 \mathrm{kt}$ & 394.40 & 273959.400 & 195331.500 & \\
\hline MIGHTY OAK & U12T.08 & $4 / 10 / 86$ & & & & & & \\
\hline $\begin{array}{l}\text { Milk Shake } \\
\text { DoD Test }\end{array}$ & U5K & $3 / 25 / 68$ & Shaft & $<20 \mathrm{kt}$ & 264.57 & 235639.474 & 217976.845 & \\
\hline Milrow & & 1969 & & & & & & $\begin{array}{l}\text { surface stations and free field } \\
\text { measurements in UA-2 satellite hole }\end{array}$ \\
\hline $\begin{array}{l}\text { Miniata } \\
\text { experiment }\end{array}$ & U2BU & 7/8/71 & Shaft & $83 \mathrm{kt}$ & 528.83 & 262018.589 & 207081.552 & \\
\hline $\begin{array}{l}\text { Mint Leaf } \\
\text { DoD Test }\end{array}$ & U12T.01 & $5 / 5 / 70$ & Tunnel & $<20 \mathrm{kt}$ & 405.38 & & & \\
\hline Controlled & & & & & & 273758.402 & 195235.763 & \\
\hline $\begin{array}{l}\text { Minute Steak } \\
\text { DoD Test }\end{array}$ & U1 1F & $9 / 12 / 69$ & Shaft & $<20 \mathrm{kt}$ & 264.57 & 236251.023 & 218206.704 & \\
\hline
\end{tabular}




\begin{tabular}{|c|c|c|c|c|c|c|c|c|}
\hline \multirow{2}{*}{$\begin{array}{l}\text { Event } \\
\text { Mission Cyber } \\
\text { DoD Test }\end{array}$} & \multirow{2}{*}{$\begin{array}{l}\text { Hole } \\
\text { U12P.02 }\end{array}$} & \multirow{2}{*}{$\begin{array}{l}\text { Event Date } \\
12 / 2 / 87\end{array}$} & \multirow{2}{*}{$\begin{array}{l}\text { Hole Type } \\
\text { Tunnel }\end{array}$} & \multirow{2}{*}{$\begin{array}{l}\text { Yield } \\
<20 \mathrm{kt}\end{array}$} & \multirow{2}{*}{$\begin{array}{l}\text { Depth of Burial } \\
270.60\end{array}$} & \multicolumn{2}{|c|}{ Nevada State Plane Coordinates } & \multirow[t]{3}{*}{ Final Reports } \\
\hline & & & & & & 275778.407 & 197057.813 & \\
\hline Mississippi & U9AD & |10/5/62 & Shaft & | $115 \mathrm{kt}$ & |493.78 & | 265268.028 & |207157.798 & \\
\hline $\begin{array}{l}\text { Misty Rain } \\
\text { DoD Test } \\
\text { Controlled }\end{array}$ & U12N.17 & $4 / 6 / 85$ & Tunnel & $<20 \mathrm{kt}$ & 388.60 & 272005.534 & 193189.759 & \\
\hline Molbo & U2OAG & $2 / 12 / 82$ & Shaft & 20 to $150 \mathrm{kt}$ & 638.00 & 274533.925 & 170505.434 & UCRL-ID-127716 (6/97) surface only \\
\hline Montello & U2OBF & $4 / 16 / 91$ & Shaft & 20 to $150 \mathrm{kt}$ & 641.60 & 276880.692 & 172364.812 & UCRL-MI-107936 (8/91) surface only \\
\hline Monterey & U4AJ & $7 / 29 / 82$ & Shaft & 20 to $150 \mathrm{kt}$ & 400.00 & 261137.517 & 204993.653 & \\
\hline $\begin{array}{l}\text { Mudpack } \\
\text { DoD Test }\end{array}$ & U10N & $12 / 16 / 64$ & Shaft & $2.7 \mathrm{kt}$ & 152.10 & 269519.976 & 205648.798 & $\begin{array}{l}\text { FF-boreholes, Perret, 1965, SC-TM-64- } \\
\text { 1749, Perret, 1970, POR-2900 (WT- } \\
\text { 2900) }\end{array}$ \\
\hline Muenster & U19E & $1 / 3 / 76$ & Shaft & 200 to $1000 \mathrm{kt}$ & 1452.40 & 282580.679 & 181965.976 & \\
\hline Mullet & U2AG & $10 / 17 / 63$ & Shaft & Low & 60.35 & 264304.822 & 205685.934 & \\
\hline Mustang & U9AT & $11 / 15 / 63$ & Shaft & Low & 165.81 & 264481.201 & 207468.408 & \\
\hline Nama-Amarylis & U9IXY31 & $8 / 5 / 71$ & Shaft & $<20 \mathrm{kt}$ & 272.80 & 265908.052 & 208666.482 & \\
\hline $\begin{array}{l}\text { Nama-Mephisto } \\
\text { Simultaneous, } \\
\text { separate holes }\end{array}$ & U9IZ27 & $8 / 5 / 71$ & Shaft & $<20 \mathrm{kt}$ & 243.84 & 265420.218 & 208849.497 & \\
\hline Narraguagus & U2f & $9 / 27 / 63$ & Shaft & Low & 150.27 & 266961.117 & 205100.601 & \\
\hline Nash & U2CE & $1 / 19 / 67$ & Shaft & $39 \mathrm{kt}$ & 365.15 & 265694.329 & 199614.178 & \\
\hline Natches & U9AK1 & $8 / 23 / 63$ & Shaft & Low & 59.13 & 263674.040 & 208507.602 & \\
\hline Natoma & U10AW & $4 / 5 / 73$ & Shaft & $<20 \mathrm{kt}$ & 243.84 & 269535.191 & 206813.282 & \\
\hline Neptune & U12C.03 & $10 / 14 / 58$ & Tunnel & 115 tons & 30.02 & & & \\
\hline Nessel & U2EP & $8 / 29 / 79$ & Shaft & 20 to $150 \mathrm{kt}$ & 464.00 & $\begin{array}{r}271235.000 \\
263241.032\end{array}$ & \begin{tabular}{|}
193858.000 \\
205725.684 \\
\end{tabular} & \\
\hline Newark & U10U & $9 / 29 / 66$ & Shaft & $<20 \mathrm{kt}$ & 229.21 & 268516.883 & 207516.463 & \\
\hline NEWPOINT & U11C & $12 / 13 / 66$ & & & 239.27 & 236249.154 & 217367.662 & \\
\hline Niza & U9CR & $7 / 10 / 81$ & Shaft & $<20 \mathrm{kt}$ & 341.00 & 264079.328 & 208636.076 & $\begin{array}{l}\text { UOPKL } 81-75(8 / 10 / 81), \text { UCRL-ID- } \\
127721 \text { (6/97) surface only }\end{array}$ \\
\hline Noggin & U9BX & $9 / 6 / 68$ & Shaft & 20 to $200 \mathrm{kt}$ & 582.17 & 264899.330 & 207441.364 & $\begin{array}{l}\text { NVO-21, UCRL-50867, free field satelite } \\
\text { hole? }\end{array}$ \\
\hline Noor & U2BE & $4 / 10 / 68$ & Shaft & 20 to $200 \mathrm{kt}$ & 381.00 & 266913.574 & 204612.829 & \\
\hline Norbo & U8C & $3 / 8 / 80$ & Shaft & $<20 \mathrm{kt}$ & 271.00 & & & $\begin{array}{l}\text { UCRL-89408, surface and free field } \\
\text { (UE8c), UCRL-ID-123238 (10/95), memo } \\
\text { from Stubbs to Hudson (1/10/83) UOPKL }\end{array}$ \\
\hline Normanna & U10CB & $7 / 12 / 84$ & Shaft & $<20 \mathrm{kt}$ & 200.00 & 271112.334 & 208535.628 & $\begin{array}{l}\text { UCRL-ID-120478 (3/95) surface and free } \\
\text { field (UE10aa) }\end{array}$ \\
\hline Oakland & U2BI & 4/4/67 & Shaft & $<20 \mathrm{kt}$ & 165.51 & 267755.217 & 204308.284 & \\
\hline $\begin{array}{l}\text { Oconto } \\
\text { Operational }\end{array}$ & U9AY & $1 / 23 / 64$ & Shaft & $10.5 \mathrm{kt}$ & 264.87 & 263835.444 & 208413.674 & \\
\hline
\end{tabular}




\begin{tabular}{|c|c|c|c|c|c|c|c|c|}
\hline Event & Hole & Event Date & Hole Type & Yield & Depth of Burial & \multicolumn{2}{|c|}{ Nevada State Plane Coordinates } & Final Reports \\
\hline Organdy & U9BO & 6/11/65 & Shaft & $<20 \mathrm{kt}$ & 168.86 & 262661.907 & 209580.555 & \\
\hline Orkney & U10BE & $5 / 2 / 84$ & Shaft & $<20 \mathrm{kt}$ & 210.00 & 271821.154 & 206791.922 & UCRL-ID-120650 (3/95) surface only \\
\hline Packard & U2U & $1 / 15 / 69$ & Shaft & $10 \mathrm{kt}$ & 246.89 & 266204.059 & 205789.512 & $\begin{array}{l}\text { FF?-UE2y?, UCRL-51112. Wheeler and } \\
\text { Preston, } 1971 .\end{array}$ \\
\hline PaisanoB358 & U9W1 & $4 / 24 / 63$ & Shaft & Low & 57.00 & 263181.549 & 208428.832 & \\
\hline Palanquin & U2OK & $4 / 14 / 65$ & Crater & $4.3 \mathrm{kt}$ & 85.65 & 280743.505 & 165091.138 & \\
\hline Palisade-1 & U4AT & $5 / 15 / 89$ & Shaft & $<20 \mathrm{kt}$ & 335.30 & 261701.721 & 200909.228 & \\
\hline Palisade-2 & U4AT & $5 / 15 / 89$ & Shaft & $<20 \mathrm{kt}$ & 390.00 & 261701.721 & 200909.228 & misc-4821 surface only \\
\hline $\begin{array}{l}\text { Palisade-3 } \\
\text { Simultaneous, } \\
\text { same hole }\end{array}$ & U4AT & $5 / 15 / 89$ & Shaft & $<20 \mathrm{kt}$ & 404.00 & 261701.721 & 200909.228 & \\
\hline Panamint & U2GB & $5 / 21 / 86$ & Shaft & $<20 \mathrm{kt}$ & 480.00 & 263667.749 & 206273.813 & \\
\hline Panir & U19YS & $8 / 31 / 78$ & Shaft & 20 to $150 \mathrm{kt}$ & 681.00 & 280285.003 & 179832.207 & \\
\hline $\begin{array}{l}\text { Par } \\
\text { Isotope production } \\
\text { and explosive } \\
\text { development }\end{array}$ & U2P & $10 / 9 / 64$ & Shaft & $38 \mathrm{kt}$ & 405.69 & 266578.473 & 204780.158 & \\
\hline Parnassia & U2BC & $11 / 30 / 71$ & Shaft & $<20 \mathrm{kt}$ & 330.71 & 267592.090 & 205374.261 & \\
\hline Passaic & U9L & $4 / 6 / 62$ & Shaft & Low & 233.48 & 262860.552 & 207734.347 & \\
\hline Pepato & U20AD & $6 / 11 / 79$ & Shaft & 20 to $150 \mathrm{kt}$ & 681.00 & 281788.225 & 171145.530 & \\
\hline Pera & U10BD & $9 / 8 / 79$ & Shaft & $<20 \mathrm{kt}$ & 200.00 & 267005.389 & 208224.482 & $\begin{array}{l}\text { UCRL-89408, surface and free field } \\
\text { (UE10bd), UCRL-ID-128633 (8/97), } \\
\text { memo from Stubbs to Hudson (1/10/83) } \\
\text { UOPKL 83-6 free field velocity records }\end{array}$ \\
\hline $\begin{array}{l}\text { Pinedrops-Bayou } \\
\text { Simultaneous, } \\
\text { same hole }\end{array}$ & U10AS & $1 / 10 / 74$ & Shaft & $<20 \mathrm{kt}$ & 342.90 & 269120.592 & 207090.672 & \\
\hline Pinedrops-Sloat & U10AS & $1 / 10 / 74$ & Shaft & $<20 \mathrm{kt}$ & 213.36 & 269120.592 & 207090.672 & \\
\hline Pinedrops-Tawny & U10AS & $1 / 10 / 74$ & Shaft & $<20 \mathrm{kt}$ & 281.94 & 269120.592 & 207090.672 & \\
\hline Pipkin & U2OB & $10 / 8 / 69$ & Shaft & 200 to $1000 \mathrm{kt}$ & 623.62 & 278132.065 & 172441.177 & \\
\hline Piton-A & U9IY30 & $5 / 28 / 70$ & Shaft & $<20 \mathrm{kt}$ & 236.22 & 265786.102 & 208727.424 & \\
\hline $\begin{array}{l}\text { Piton-B } \\
\text { Simultaneous, } \\
\text { separate holes }\end{array}$ & U9IX27 & $5 / 28 / 70$ & Shaft & $<20 \mathrm{kt}$ & 228.60 & 265420.097 & 208606.025 & \\
\hline Piton-C & U9IAA25 & $5 / 28 / 70$ & Shaft & $<20 \mathrm{kt}$ & 100.58 & 265176.600 & 208971.603 & \\
\hline Plaid II & U2R & $2 / 3 / 66$ & Shaft & $<20 \mathrm{kt}$ & 268.53 & 263804.976 & 205466.128 & \\
\hline Platte & U12K.01 & $4 / 14 / 62$ & Tunnel & $1.85 \mathrm{kt}$ & 191.41 & 274380.000 & 197592.000 & \\
\hline
\end{tabular}




\begin{tabular}{|c|c|c|c|c|c|c|c|c|}
\hline \multirow{2}{*}{\begin{tabular}{|l|} 
Event \\
Player \\
\end{tabular}} & \multirow{2}{*}{\begin{tabular}{|l|} 
Hole \\
U9CC \\
\end{tabular}} & \multirow{2}{*}{\begin{tabular}{|l|} 
Event Date \\
$8 / 27 / 64$ \\
\end{tabular}} & \multirow{2}{*}{\begin{tabular}{|l|} 
Hole Type \\
Shaft \\
\end{tabular}} & \multirow[t]{2}{*}{ Yield } & \multirow{2}{*}{\begin{tabular}{|l|} 
Depth of Burial \\
90.22 \\
\end{tabular}} & \multicolumn{2}{|c|}{ Nevada State Plane Coordinates } & \multirow[t]{2}{*}{ Final Reports } \\
\hline & & & & & & 262827.478 & 208032.433 & \\
\hline Pleasant & U9AH & $5 / 29 / 63$ & Shaft & Low & 210.92 & 264015.048 & 207864.564 & \\
\hline Pod-A & U2CK & $10 / 29 / 69$ & Shaft & $\begin{array}{l}16.7 \mathrm{kt} \\
\text { (Total) }\end{array}$ & 266.70 & 265313.928 & 200034.352 & \\
\hline Pod-B & $\mathrm{U} 2 \mathrm{CH}$ & 10/29/69 & Shaft & & 248.72 & 265335.054 & 199027.145 & \\
\hline Pod-C & $\mathrm{U} 2 \mathrm{Cl}$ & 10/29/69 & Shaft & & 170.69 & 264879.118 & 199195.855 & \\
\hline $\begin{array}{l}\text { Pod-D } \\
\text { Simultaneous, } \\
\text { separate holes } \\
\text { only }\end{array}$ & U2CJ & $10 / 29 / 69$ & Shaft & & 312.42 & 264771.121 & 199552.980 & \\
\hline Polka & U10AI & $12 / 6 / 67$ & Shaft & $<20 \mathrm{kt}$ & 190.50 & 267470.713 & 206910.191 & \\
\hline Polygonum & U2BY & $10 / 2 / 73$ & Shaft & $<20 \mathrm{kt}$ & 213.36 & 267406.004 & 205130.728 & \\
\hline Pongee & $\mathrm{U} 2 \mathrm{AH}$ & $7 / 22 / 65$ & Shaft & $<20 \mathrm{kt}$ & 134.72 & 264414.373 & 205694.548 & \\
\hline Portmanteau & U2AX & $8 / 30 / 74$ & Shaft & 20 to $200 \mathrm{kt}$ & 655.29 & 266700.619 & 204216.317 & surface only, Wheeler memo $6 / 25 / 80$ \\
\hline Portola & U10BB & $2 / 6 / 75$ & Shaft & $<20 \mathrm{kt}$ & 198.10 & 269595.481 & 207020.458 & \\
\hline Portulaca & U2BV & $6 / 28 / 73$ & Shaft & 20 to $200 \mathrm{kt}$ & 466.34 & 266249.096 & 203995.029 & \\
\hline Potrero & U2EB & $4 / 23 / 74$ & Shaft & $<20 \mathrm{kt}$ & 210.31 & 267535.602 & 204825.930 & \\
\hline Purse & U20V & $5 / 7 / 69$ & Shaft & 20 to $200 \mathrm{kt}$ & 598.78 & 281026.272 & 167122.284 & \\
\hline Quargel & U2FB & $11 / 18 / 78$ & Shaft & 20 to $150 \mathrm{kt}$ & 542.00 & 263858.314 & 204185.898 & \\
\hline Queso & U10BF & $8 / 11 / 82$ & Shaft & $<20 \mathrm{kt}$ & 216.00 & 270861.123 & 207355.870 & $\begin{array}{l}\text { UCRL-ID-121259 (9/95) surface and free } \\
\text { field (UE10bf) }\end{array}$ \\
\hline Rack & U9AP & 8/15/68 & Shaft & $\mid<20 \mathrm{kt}$ & | 199.64 & 263530.299 & 207355.818 & \\
\hline \multirow[t]{2}{*}{ Rainier } & U12B & $9 / 19 / 57$ & Tunnel & $1.7 \mathrm{kt}$ & 274.02 & & & \\
\hline & & & & & & 271446.843 & 193548.954 & UCRL-5542-rev., Warner and Violet, 1959 \\
\hline $\begin{array}{l}\text { Randsburg } \\
\text { Simultaneous, } \\
\text { separate drifts }\end{array}$ & U12N.22 & $7 / 25 / 90$ & Tunnel & $<20 \mathrm{kt}$ & 389.40 & & & \\
\hline DoD Test & & & & & & 272671.000 & 192556.000 & \\
\hline Raritan & |U9U & |9/6/62 & Shaft & Low & 157.28 & 264262.366 & 207660.908 & \\
\hline Reblochon & U2EN & $2 / 23 / 78$ & Shaft & 20 to $150 \mathrm{kt}$ & 658.40 & 263515.282 & 205968.985 & \\
\hline REO & U10M & $1 / 22 / 66$ & & & 208.18 & 267250.241 & 208178.405 & \\
\hline $\operatorname{Rex}$ & $\mathrm{U} 2 \mathrm{OH}$ & $2 / 24 / 66$ & Shaft & $19 \mathrm{kt}$ & 671.17 & 279811.443 & 173049.370 & \\
\hline $\begin{array}{l}\text { Rhyolite } \\
\text { Simultaneous with } \\
\text { Nightingale }\end{array}$ & U2EY & $6 / 22 / 88$ & Shaft & $<150 \mathrm{kt}$ & 207.30 & 268224.537 & 205191.771 & misc-4642 surface only \\
\hline RIO BLANCO & OCORBL & $5 / 17 / 73$ & & $33 \mathrm{kt}$ & 1780.03 & -99.900 & -99.900 & $\begin{array}{l}\text { UCRL-51504 (Toman and others, 1973), } \\
\text { FF-boreholes. }\end{array}$ \\
\hline Riola & U2EQ & $9 / 25 / 80$ & Shaft & $1.07 \mathrm{kt}$ & 424.00 & 262647.731 & 205908.988 & \\
\hline Rivet I & U10AA & $1 / 18 / 67$ & Shaft & $<20 \mathrm{kt}$ & 151.79 & 268124.047 & 207474.718 & \\
\hline
\end{tabular}




\begin{tabular}{|c|c|c|c|c|c|c|c|c|}
\hline \multirow{2}{*}{\begin{tabular}{|l|} 
Event \\
Rivet II
\end{tabular}} & \multirow{2}{*}{\begin{tabular}{|l|} 
Hole \\
U10Z
\end{tabular}} & \multirow{2}{*}{\begin{tabular}{|l|} 
Event Date \\
$1 / 26 / 67$
\end{tabular}} & \multirow{2}{*}{\begin{tabular}{|l} 
Hole Type \\
Shaft
\end{tabular}} & \multirow{2}{*}{$\begin{array}{l}\text { Yield } \\
<20 \mathrm{kt}\end{array}$} & \multirow{2}{*}{\begin{tabular}{|l|} 
Depth of Burial \\
197.51
\end{tabular}} & \multicolumn{2}{|c|}{ Nevada State Plane Coordinates } & \multirow[t]{2}{*}{ Final Reports } \\
\hline & & & & & & 268087.318 & 207340.764 & \\
\hline Rivet III & U10Y & $3 / 2 / 67$ & Shaft & $<20 \mathrm{kt}$ & 273.71 & 268206.050 & 207282.949 & \\
\hline Rivoli & U2EG & $5 / 20 / 76$ & Shaft & $<20 \mathrm{kt}$ & 200.00 & 265014.282 & 205715.451 & \\
\hline ROANOKE & U9Q & 10/12/62 & & & & & & $5 / 23 / 67$ \\
\hline Romano & U2EX & $12 / 16 / 83$ & Shaft & 20 to $150 \mathrm{kt}$ & 515.00 & 265371.728 & 205225.332 & \\
\hline Roquefort & U4AS & $10 / 16 / 85$ & Shaft & 20 to $150 \mathrm{kt}$ & 415.00 & 261960.823 & 200863.632 & UCRL-ID-119552 (12/94) surface only \\
\hline Rovena & U10S & $8 / 10 / 66$ & Shaft & $<20 \mathrm{kt}$ & 195.07 & 268516.913 & 207363.969 & \\
\hline Sacramento & U9V & $6 / 30 / 62$ & Shaft & Low & 149.05 & 262829.441 & 207432.018 & \\
\hline $\begin{array}{l}\text { Salmon } \\
\text { Nuclear test } \\
\text { detection research } \\
\text { experiment }\end{array}$ & OMSLAM & $10 / 22 / 64$ & Shaft & $5.3 \mathrm{kt}$ & 828.14 & -99.900 & -99.900 & $\begin{array}{l}\text { FF meas.-boreholes, Perret, 1968, VUF- } \\
3012\end{array}$ \\
\hline Salut & U2OAK & $6 / 12 / 85$ & Shaft & 20 to $150 \mathrm{kt}$ & 608.00 & 277139.665 & 168157.165 & |UCRL-ID-121263 (5/95) surface only \\
\hline Santee & U10F & $10 / 27 / 62$ & Shaft & Low & 318.52 & 266365.274 & 206868.308 & \\
\hline Sappho & U2DH2 & $3 / 23 / 72$ & Shaft & $<20 \mathrm{kt}$ & 197.82 & 262326.294 & 204466.549 & \\
\hline Satsop & U2G & $8 / 15 / 63$ & Shaft & Low & 226.16 & 266883.249 & 204810.913 & \\
\hline Saturn & U12C.02 & $8 / 10 / 57$ & Tunnel & Zero & 39.01 & -99.900 & -99.900 & \\
\hline Satz & U2DQ & 7/7/78 & Shaft & $<20 \mathrm{kt}$ & 315.00 & 262189.378 & 204795.310 & \\
\hline $\begin{array}{l}\text { Saxon } \\
\text { Excavation }\end{array}$ & $\mathrm{U} 2 \mathrm{CC}$ & $7 / 28 / 66$ & Shaft & $<20 \mathrm{kt}$ & 153.62 & 265343.884 & 199797.299 & \\
\hline Schellbourne & U2GF & $5 / 13 / 88$ & Shaft & $<150 \mathrm{kt}$ & 463.00 & 263594.616 & 205231.395 & misc- 4688 surface only \\
\hline Schooner & U2OU & $12 / 8 / 68$ & Crater & $30 \mathrm{kt}$ & 111.25 & 287734.634 & 161330.957 & \\
\hline Scotch & U19as & $5 / 23 / 67$ & & $155 \mathrm{kt}$ & & & & Surface stations, HN-20-1028 (1969). \\
\hline Scree-Acajou & U9IX24 & $10 / 13 / 70$ & Shaft & $<20 \mathrm{kt}$ & 249.94 & 265060.657 & 208605.610 & \\
\hline Scree-Alhambra & U9IZ21 & $10 / 13 / 70$ & Shaft & $<20 \mathrm{kt}$ & 192.02 & 264689.026 & 208849.393 & \\
\hline $\begin{array}{l}\text { Scree-Chamois } \\
\text { Simultaneous, } \\
\text { separate holes }\end{array}$ & U9IZ24 & $10 / 13 / 70$ & Shaft & & 100.58 & 265054.040 & 208849.487 & \\
\hline $\begin{array}{l}\text { Scroll } \\
\text { Nuclear test } \\
\text { detection } \\
\text { experiment }\end{array}$ & U19N & $4 / 23 / 68$ & Shaft & $<20 \mathrm{kt}$ & 224.03 & 287135.661 & 178194.053 & \\
\hline $\begin{array}{l}\text { Scuttle } \\
\text { by aircraft only }\end{array}$ & $\mathrm{U} 2 \mathrm{BH}$ & $11 / 13 / 69$ & Shaft & $1.7 \mathrm{kt}$ & 164.59 & 268053.693 & 204963.249 & \\
\hline Seafoam & U2EA & $12 / 13 / 73$ & Shaft & $<20 \mathrm{kt}$ & 198.12 & 267695.735 & 205123.224 & \\
\hline Seco & U8L & $2 / 25 / 81$ & Shaft & $<20 \mathrm{kt}$ & 200.00 & 269964.503 & 204114.813 & UCRL-ID-127715 (6/97) surface only \\
\hline
\end{tabular}




\begin{tabular}{|c|c|c|c|c|c|c|c|c|}
\hline \multirow[b]{2}{*}{$\begin{array}{l}\text { Event } \\
\text { Sedan } \\
\text { Crater } 1280 \mathrm{ft} . \\
\text { diameter, } 320 \mathrm{ft} \text {. } \\
\text { deep } \\
\text { Excavation } \\
\text { experiment } \\
\text { Thermonuclear } \\
\text { device }\end{array}$} & \multirow[b]{2}{*}{$\begin{array}{l}\text { Hole } \\
\text { U10H }\end{array}$} & \multirow[b]{2}{*}{$\begin{array}{l}\text { Event Date } \\
7 / 6 / 62\end{array}$} & \multirow[b]{2}{*}{$\begin{array}{l}\text { Hole Type } \\
\text { Crater }\end{array}$} & \multirow[b]{2}{*}{$\begin{array}{l}\text { Yield } \\
104 \mathrm{kt}\end{array}$} & \multirow[b]{2}{*}{\begin{tabular}{|l|} 
Depth of Burial \\
193.55
\end{tabular}} & \multicolumn{2}{|c|}{ Nevada State Plane Coordinates } & \multirow[b]{2}{*}{$\begin{array}{l}\text { Final Reports } \\
\\
\text { surface meas., PNE-213F (Mickey, 1963). }\end{array}$} \\
\hline & & & & & & 269443.763 & 207569.166 & \\
\hline Seersucker & U9BM & $2 / 19 / 65$ & Shaft & $<20 \mathrm{kt}$ & 144.17 & 262824.116 & 208892.449 & \\
\hline Serena & U2OAN & $7 / 25 / 85$ & Shaft & 20 to $150 \mathrm{kt}$ & 597.00 & 282630.429 & 172666.903 & \\
\hline Serpa & U19AI & $12 / 17 / 80$ & Shaft & 20 to $150 \mathrm{kt}$ & 573.00 & 285720.064 & 183551.461 & \\
\hline Shoal & cent NV & $10 / 26 / 63$ & & & & & & $\begin{array}{l}\text { surface stations, Perret, 1967, SC-RR-66- } \\
696 \text {; free field measurements in shaft and } \\
\text { boreholes; Sandia report VUF-2001, final } \\
\text { report }\end{array}$ \\
\hline Shuffle & U10T & $4 / 18 / 68$ & Shaft & 20 to $200 \mathrm{kt}$ & 493.17 & 266730.733 & 208330.808 & \\
\hline Silene & U9CK & $6 / 28 / 73$ & Shaft & $<20 \mathrm{kt}$ & 198.12 & 262555.184 & 208011.158 & \\
\hline $\begin{array}{l}\text { Simms } \\
\text { Excavation }\end{array}$ & U10W & $11 / 5 / 66$ & Shaft & $<20 \mathrm{kt}$ & 198.73 & 268660.008 & 207412.334 & \\
\hline Small Boy & area 5 & $7 / 14 / 62$ & & low & & & & $\begin{array}{l}\text { Barton memo, 4/4/63, 63-9716.3-588, } \\
\text { surface meas. }\end{array}$ \\
\hline Solanum & U9IW24.5 & $12 / 14 / 72$ & Shaft & $<20 \mathrm{kt}$ & 201.17 & 265130.935 & 208544.647 & \\
\hline SPIDER & U2BP1 & $8 / 14 / 69$ & & & 213.36 & 267573.059 & 205963.114 & \\
\hline SPIDER & U2BP2 & $8 / 14 / 69$ & & & 227.69 & 267344.885 & 205948.511 & \\
\hline Spoon & U9BD & $9 / 11 / 64$ & Shaft & $<20 \mathrm{kt}$ & 179.83 & 262433.011 & 209382.669 & \\
\hline St. Lawrence & U2B & $11 / 9 / 62$ & Shaft & Low & 166.73 & 267964.014 & 205100.406 & \\
\hline Staccato & U10AH & $1 / 19 / 68$ & Shaft & 20 to $200 \mathrm{kt}$ & 443.48 & 267150.312 & 206829.851 & \\
\hline Stanley & U10Q & $7 / 27 / 67$ & Shaft & 20 to $200 \mathrm{kt}$ & 483.72 & 266304.183 & 207310.263 & \\
\hline Stanyan & U2AW & $9 / 26 / 74$ & Shaft & 20 to $200 \mathrm{kt}$ & 572.99 & 264505.899 & 205557.595 & \\
\hline Starwort & U2BS & $4 / 26 / 73$ & Shaft & $90 \mathrm{kt}$ & 563.88 & 263448.293 & 206441.892 & \\
\hline $\begin{array}{l}\text { Sterling } \\
\text { Nuclear test } \\
\text { detection }\end{array}$ & OMSS1A2 & $12 / 3 / 66$ & Shaft & 380 tons & 828.14 & & & \\
\hline experiment & & & & & & -99.900 & -99.900 & FF-boreholes, Perret, 1968, SC-RR-68-410 \\
\hline Stillwater & U9C & $2 / 8 / 62$ & Shaft & $3.07 \mathrm{kt}$ & 181.36 & 263917.878 & 206959.538 & \\
\hline Stilton & U2OP & $6 / 3 / 75$ & Shaft & 20 to $200 \mathrm{kt}$ & 731.50 & 287366.405 & 165140.958 & \\
\hline $\begin{array}{l}\text { Stoddard } \\
\text { Excavation }\end{array}$ & U2CMS & $9 / 17 / 68$ & Shaft & 20 to $200 \mathrm{kt}$ & 467.87 & 263058.084 & 200316.171 & NVO-21, hole meas? \\
\hline Stones & U9AE & $5 / 22 / 63$ & Shaft & Intermediate & 393.19 & 262128.247 & 208178.719 & \\
\hline Stutz & U2CA & $4 / 6 / 66$ & Shaft & $<20 \mathrm{kt}$ & 226.16 & 265232.757 & 199113.208 & \\
\hline Suede & U9BK & $3 / 20 / 65$ & Shaft & $<20 \mathrm{kt}$ & 143.26 & 262621.183 & 209292.759 & \\
\hline
\end{tabular}




\begin{tabular}{|c|c|c|c|c|c|c|c|c|}
\hline \multirow[b]{2}{*}{\begin{tabular}{|l|} 
Event \\
Sulky \\
Excavation test of \\
explosive buried at \\
greater depth in \\
relation to yield \\
Produced mound \\
of broken rock \\
\end{tabular}} & \multirow[b]{2}{*}{$\begin{array}{l}\text { Hole } \\
\text { U1 8D }\end{array}$} & \multirow{2}{*}{$\begin{array}{l}\text { Event Date } \\
12 / 18 / 64\end{array}$} & \multirow{2}{*}{$\begin{array}{l}\text { Hole Type } \\
\text { Shaft }\end{array}$} & \multirow{2}{*}{$\begin{array}{l}\text { Yield } \\
92 \text { tons }\end{array}$} & \multirow{2}{*}{\begin{tabular}{|l} 
Depth of Burial \\
27.13
\end{tabular}} & \multicolumn{2}{|c|}{ Nevada State Plane Coordinates } & \multirow[t]{2}{*}{ Final Reports } \\
\hline & & & & & & 258848.587 & 181216.377 & \\
\hline Sutter & U2BW & $12 / 21 / 76$ & Shaft & $<20 \mathrm{kt}$ & 200.00 & 266647.306 & 205984.236 & \\
\hline $\begin{array}{l}\text { Switch } \\
\text { Excavation }\end{array}$ & U9BV & $6 / 22 / 67$ & Shaft & $<20 \mathrm{kt}$ & 302.06 & 263743.992 & 209093.236 & \\
\hline Tafi & U2OAE & $7 / 25 / 80$ & Shaft & 20 to $150 \mathrm{kt}$ & 680.00 & 278081.487 & 169189.009 & \\
\hline Tamalpais & U12B.02 & $10 / 8 / 58$ & Tunnel & 72 tons & 100.58 & 271395.000 & 193789.000 & \\
\hline Tanya & U2DT & 7/30/68 & Shaft & 20 to $200 \mathrm{kt}$ & 381.00 & 262738.174 & 204338.070 & NVO-21, hole meas? \\
\hline Tapestry & U2AN & $5 / 12 / 66$ & Shaft & $<20 \mathrm{kt}$ & 248.72 & 264688.517 & 205313.901 & \\
\hline Tarko & U2FD & $2 / 28 / 80$ & Shaft & $<20 \mathrm{kt}$ & 369.00 & 263820.171 & 203774.433 & UCRL-ID-127858 (6/97) surface only \\
\hline Taunton & U9AA & $12 / 4 / 62$ & Shaft & Low & 227.08 & 264012.180 & 207194.310 & \\
\hline Tee & U2AB & $5 / 7 / 65$ & Shaft & $7 \mathrm{kt}$ & 184.40 & 265365.464 & 205706.563 & \\
\hline Teleme & U9CL & $2 / 6 / 75$ & Shaft & $<20 \mathrm{kt}$ & 304.80 & 262479.176 & 209778.925 & \\
\hline Temescal & U4AB & $11 / 2 / 74$ & Shaft & $<20 \mathrm{kt}$ & 262.71 & 260116.825 & 203515.385 & \\
\hline $\begin{array}{l}\text { Templar } \\
\text { Excavation }\end{array}$ & U9BT & $3 / 24 / 66$ & Shaft & $<20 \mathrm{kt}$ & 149.96 & 262386.626 & 208862.923 & \\
\hline Tenabo & U2OBB & $10 / 12 / 90$ & Shaft & 20 to $150 \mathrm{kt}$ & 600.00 & 277139.665 & 167699.866 & UCRL-MI-106506 none \\
\hline Terrine-White & U9BI1 & $12 / 18 / 69$ & Shaft & 20 to $200 \mathrm{kt}$ & 457.20 & 263177.102 & 208553.465 & \\
\hline $\begin{array}{l}\text { Terrine-Yellow } \\
\text { Simultaneous, } \\
\text { separate holes }\end{array}$ & U9BI2 & $12 / 18 / 69$ & Shaft & 20 to $200 \mathrm{kt}$ & 417.58 & 263203.763 & 209101.265 & \\
\hline THROW & U2BG & $4 / 10 / 68$ & & & & & & \\
\hline $\begin{array}{l}\text { Throw } \\
\text { Simultaneous, } \\
\text { separate holes }\end{array}$ & U2BG & $4 / 10 / 68$ & Shaft & $<20 \mathrm{kt}$ & 228.60 & 267167.046 & 204307.974 & \\
\hline Ticking & U9BJ & $8 / 21 / 65$ & Shaft & $<20 \mathrm{kt}$ & 208.48 & 262311.502 & 209336.943 & \\
\hline Tierra & U19AC & $12 / 15 / 84$ & Shaft & 20 to $150 \mathrm{kt}$ & 640.00 & 280904.325 & 184434.944 & \\
\hline Tilci & U4AK & $11 / 11 / 81$ & Shaft & 20 to $150 \mathrm{kt}$ & 445.00 & 258257.603 & 205587.963 & $\begin{array}{l}\text { UCRL-89408,surface and free field } \\
\text { (UE4ae), UCRL-ID-127717 (6/97), memo } \\
\text { from Stubbs to Hudson ( } 1 / 10 / 83) \text { UOPKL } \\
83-6 \text { free field velocity records }\end{array}$ \\
\hline Tinderbox & U9AZ & $11 / 22 / 68$ & Shaft & $<20 \mathrm{kt}$ & 441.96 & 265328.949 & 207873.918 & NVO-21, hole meas? \\
\hline
\end{tabular}




\begin{tabular}{|c|c|c|c|c|c|c|c|c|}
\hline Event & Hole & Event Date & Hole Type & Yield & Depth of Burial & \multicolumn{2}{|c|}{ Nevada State Plane Coordinates } & Final Reports \\
\hline $\begin{array}{l}\text { Tiny Tot } \\
\text { DoD Test }\end{array}$ & U15E & $6 / 17 / 65$ & Tunnel & $<20 \mathrm{kt}$ & 110.95 & 274587.054 & 206507.573 & \\
\hline Tioga & U9F & $10 / 18 / 62$ & Shaft & Low & 59.44 & 264069.412 & 208061.151 & \\
\hline $\begin{array}{l}\text { Tomme/Midnight } \\
\text { Zephyr } \\
\text { DoD Test }\end{array}$ & U12N.18 & $9 / 21 / 83$ & Tunnel & $<20 \mathrm{kt}$ & 404.80 & 272993.709 & 193000.127 & \\
\hline Tornillo & U9AQ & $10 / 11 / 63$ & Shaft & Low & 149.66 & 262984.855 & 208635.770 & \\
\hline Toyah & U9AC & $3 / 15 / 63$ & Shaft & Low & 130.45 & 263765.066 & 207660.567 & \\
\hline Traveler & U2CD & $5 / 4 / 66$ & Shaft & $<20 \mathrm{kt}$ & 197.51 & 264963.237 & 199446.742 & \\
\hline Trumbull & U4AA & $9 / 26 / 74$ & Shaft & $<20 \mathrm{kt}$ & 262.71 & 260116.770 & 203240.879 & \\
\hline Tub-A & U10AJC & $6 / 6 / 68$ & Shaft & $<20 \mathrm{kt}$ & 188.98 & 268388.175 & 207833.566 & \\
\hline Tub-B & U10AJB & $6 / 6 / 68$ & Shaft & $<20 \mathrm{kt}$ & 188.98 & 268157.435 & 207750.523 & \\
\hline Tub-C & U10AJF & $6 / 6 / 68$ & Shaft & $<20 \mathrm{kt}$ & 188.98 & 268157.812 & 207995.610 & \\
\hline Tub-D & U10AJD & $6 / 6 / 68$ & Shaft & $<20 \mathrm{kt}$ & 273.10 & 268331.866 & 207627.892 & \\
\hline $\begin{array}{l}\text { Tub-F } \\
\text { Simultaneous, } \\
\text { separate holes }\end{array}$ & U10AJA & $6 / 6 / 68$ & Shaft & $<20 \mathrm{kt}$ & 188.98 & 268332.271 & 207872.918 & \\
\hline Tun-A & U10AM1 & $12 / 10 / 69$ & Shaft & $<20 \mathrm{kt}$ & 199.64 & 268392.320 & 204566.731 & \\
\hline Tun-B & U10AM2 & $12 / 10 / 69$ & Shaft & $<20 \mathrm{kt}$ & 193.85 & 268590.343 & 204566.728 & \\
\hline Tun-C & U10AM3 & $12 / 10 / 69$ & Shaft & $<20 \mathrm{kt}$ & 193.70 & 268391.790 & 204764.851 & \\
\hline $\begin{array}{l}\text { Tun-D } \\
\text { Simultaneous, } \\
\text { separate holes }\end{array}$ & U10AM4 & $12 / 10 / 69$ & Shaft & $<20 \mathrm{kt}$ & 256.34 & 268589.953 & 204765.394 & \\
\hline Turf & U10C & $4 / 24 / 64$ & Shaft & 20 to $200 \mathrm{kt}$ & 506.27 & 266395.852 & 206700.646 & \\
\hline Tweed & U9BN & $5 / 21 / 65$ & Shaft & $<20 \mathrm{kt}$ & 284.38 & 262966.665 & 209184.704 & \\
\hline Tybo & U2OY & $5 / 14 / 75$ & Shaft & 200 to $1000 \mathrm{kt}$ & 765.00 & 274138.180 & 169483.105 & $\begin{array}{l}\text { UOPBA } 76-45(3-1-76) \text { surface only } \\
\text { Wheeler and Preston }\end{array}$ \\
\hline Tyg-A & U2DC4 & $12 / 12 / 68$ & Shaft & $<20 \mathrm{kt}$ & 228.30 & 263189.176 & 204484.273 & \\
\hline Tyg-B & U2DC5 & $12 / 12 / 68$ & Shaft & $<20 \mathrm{kt}$ & 251.16 & 262830.992 & 204575.092 & \\
\hline Tyg-C & U2DC3 & $12 / 12 / 68$ & Shaft & $<20 \mathrm{kt}$ & 228.30 & 262883.421 & 204781.814 & \\
\hline Tyg-D & U2DC2 & $12 / 12 / 68$ & Shaft & $<20 \mathrm{kt}$ & 206.96 & 263241.565 & 204690.684 & \\
\hline Tyg-E & U2DC1 & $12 / 12 / 68$ & Shaft & $<20 \mathrm{kt}$ & 197.82 & 263088.472 & 204839.771 & \\
\hline $\begin{array}{l}\text { Tyg-F } \\
\text { Simultaneous, } \\
\text { separate holes }\end{array}$ & U2DC6 & $12 / 12 / 68$ & Shaft & $<20 \mathrm{kt}$ & 264.87 & 262972.633 & 204381.967 & \\
\hline Uranus & U12C.01 & $3 / 14 / 58$ & Tunnel & $<1$ ton & 34.75 & -99.900 & -99.900 & \\
\hline Valise & U9BY & $3 / 18 / 69$ & Shaft & $\mid<20 \mathrm{kt}$ & 91.44 & 265244.208 & 208000.234 & \\
\hline Vat & U9CF & $10 / 10 / 68$ & Shaft & $<20 \mathrm{kt}$ & 192.02 & 264596.943 & 207874.083 & \\
\hline
\end{tabular}




\begin{tabular}{|c|c|c|c|c|c|c|c|c|}
\hline Event & Hole & Event Date & Hole Type & Yield & Depth of Burial & \multicolumn{2}{|c|}{ Nevada State Plane Coordinates } & Final Reports \\
\hline Venus & U12D.01 & $2 / 22 / 58$ & Tunnel & $<1$ ton & 30.48 & -99.900 & -99.900 & \\
\hline Vide & U8K & $4 / 30 / 81$ & Shaft & $<20 \mathrm{kt}$ & 323.00 & 269457.791 & 204072.503 & $\begin{array}{l}\text { UCRL-ID-125022 (3/96) surface only } \\
\text { (FF???), memo from Stubbs } 11 / 6 / 80 \text {, } \\
\text { UOPKL 80-84 }\end{array}$ \\
\hline Vigil & U10AD & $11 / 22 / 66$ & Shaft & $<20 \mathrm{kt}$ & 91.44 & 268596.088 & 207314.643 & \\
\hline Ville & U4AM & $6 / 12 / 85$ & Shaft & $<20 \mathrm{kt}$ & 293.20 & 259579.803 & 204206.430 & UCRL-ID-120666 (5/95) surface only \\
\hline VILLE & U4am & $6 / 12 / 85$ & & & 293.20 & 259579.803 & 204206.430 & \\
\hline Vito & U10AB & $7 / 14 / 67$ & Shaft & $<20 \mathrm{kt}$ & 96.62 & 268139.223 & 207618.136 & \\
\hline $\begin{array}{l}\text { Vulcan } \\
\text { Heavy element } \\
\text { production }\end{array}$ & U2BD & $6 / 25 / 66$ & Shaft & $25 \mathrm{kt}$ & 322.78 & 267020.348 & 205207.145 & \\
\hline Waller & U2BZ & $10 / 2 / 73$ & Shaft & $<20 \mathrm{kt}$ & 310.90 & 266868.113 & 205603.242 & \\
\hline Ward & U10X & $2 / 8 / 67$ & Shaft & $<20 \mathrm{kt}$ & 259.99 & 268390.391 & 207421.180 & \\
\hline Washer & U10R & $8 / 10 / 67$ & Shaft & $<20 \mathrm{kt}$ & 466.34 & 267188.239 & 207416.434 & \\
\hline Wexford & U2CR & $8 / 30 / 84$ & Shaft & $<20 \mathrm{kt}$ & 314.00 & 265725.175 & 200497.841 & UCRL-ID-121265 (5/95) surface only \\
\hline White & U9B & $5 / 25 / 62$ & Shaft & Low & 192.63 & 263653.113 & 207020.147 & \\
\hline Wichita & U9Y & $7 / 27 / 62$ & Shaft & Low & 150.27 & 264189.223 & 206617.682 & \\
\hline $\begin{array}{l}\text { Wineskin } \\
\text { WINESKIN }\end{array}$ & $\begin{array}{l}\text { U12r } \\
\text { U12R }\end{array}$ & $\begin{array}{l}1 / 15 / 69 \\
1 / 15 / 69\end{array}$ & Shaft & 20 to $200 \mathrm{kt}$ & $\begin{array}{l}518.16 \\
174.96\end{array}$ & $\begin{array}{l}272918.750 \\
229667.189\end{array}$ & $\begin{array}{l}191567.165 \\
216408.147\end{array}$ & \\
\hline WISHBONE & U5A & 2/18/65 & & & & & & \\
\hline Wool & U9BH & $1 / 14 / 65$ & Shaft & $<20 \mathrm{kt}$ & 216.10 & 263021.572 & 209443.526 & \\
\hline Worth & U10AG & $10 / 25 / 67$ & Shaft & $<20 \mathrm{kt}$ & 187.45 & 267148.200 & 207299.235 & \\
\hline Yannigan-Blue & U2AY3 & $2 / 26 / 70$ & Shaft & 20 to $200 \mathrm{kt}$ & 363.63 & 262418.490 & 205801.003 & \\
\hline Yannigan-Red & U2AY1 & $2 / 26 / 70$ & Shaft & 20 to $200 \mathrm{kt}$ & 391.97 & 262704.811 & 206186.219 & \\
\hline $\begin{array}{l}\text { Yannigan-White } \\
\text { Simultaneous, } \\
\text { separate holes }\end{array}$ & U2AY2 & $2 / 26 / 70$ & Shaft & 20 to $200 \mathrm{kt}$ & 394.72 & 262889.310 & 205740.341 & \\
\hline Yard & U10AF & $9 / 7 / 67$ & Shaft & 20 to $200 \mathrm{kt}$ & 521.21 & 266792.803 & 206929.457 & \\
\hline York & U9Z & $8 / 24 / 62$ & Shaft & Low & 226.47 & 262969.710 & 208136.053 & \\
\hline Yuba & U12B.10 & $6 / 5 / 63$ & Tunnel & $3.1 \mathrm{kt}$ & 242.62 & & & \\
\hline Operational & & & & & & 271532.608 & 193014.529 & \\
\hline Zinnia & U2DK & $5 / 17 / 72$ & Shaft & $<20 \mathrm{kt}$ & 322.78 & 263155.544 & 203832.713 & \\
\hline
\end{tabular}


Appendix 3A

Memorandum for Excel Spread Sheet

John Rambo 


\section{Appendix 3A}

\section{MEMORANDUM}

TO: $\quad$ Distribution

FROM: John Rambo

DATE: $\quad$ February 18, 2005

SUBJECT: New Ground Motion and Containment Diagnostics

Spreadsheet Rev. 2

\section{INTRODUCTION}

I have taken the spreadsheet ${ }^{1,2}$ that gave the locations of all the documents in the Containment Diagnostics Library (room 1113 in T1406) and modified it to include free field ground motion and containment diagnostics documents that are available elsewhere in the T1406. The original spreadsheet will be preserved to find documents currently located in T1406. That spreadsheet mentions the existence ground motion data and also other containment diagnostics. The new spreadsheet is titled ["Ground Motion Data Appendix 3"]. Its function is to indicate existence of documents, digital data, or paper records we (LLNL Containment Program) have related to free field, free surface, and containment diagnostics. Each is associated with an event name. Additional information was added from other ground motion documents and the spreadsheet includes the mention of classified reports with unclassified titles with a symbol (U) appended to the title.

The lead for this project, Bill Foxall, was interested in where we could find free surface and free field data on any event. The project relates to Yucca Mountain worries about earthquake damage. The money ran out at the end of this last fiscal year. This memo serves to explain what was done so far, what was not done and what could be done in the future if the money is available. It also serves to save time for the person who picks up the project and needs to know what to do for improvements.

The spreadsheet, even in its current form, has value to others who seek out free field data for calculations and containment related issues. Prior to this project there have been a number of requests for event free field ground motion data. Up until now, it has been a somewhat laborious process of going through reports to find it or to find the appropriate reports in the first place.

\section{WHAT WAS DONE}

A column was added to the old spreadsheet that specifies the number of free surface gages and subsurface free field gages. Included in the subsurface gages are free field ground motion and stress gages with the organization that fielded the gage. Information from three reports ${ }^{4,5,6}$ specified the existence of free field data and the report reference were added to the appropriate columns. One report by $\mathrm{LLNL}^{4}$ took information from Perret and Bass (Sandia) ${ }^{6}$ and added LLNL event data to it. This was used to account for the older data up to 1974. It included LANL, Sandia and DOD data. After 
that date the information was taken from all LLNL's Containment Data Reports (CDR). The CDR data went from 7/1977 to the end of testing in1992. I went through all of the CDR's and extracted the existence of free field and free surface data. References 4, 5, and 6 also mention POR, (Project Officers Report), WT (Weapons Test), Sandia, Physics International (PI), SCUBED, UCID's, UCRL's, and other reporting agency reports. These report numbers were included but most likely are not in our possession. However, the reports library may have copies of a number of them. I also recall running across POR and WT reports in the archives during the declassification process. Many of them will be classified.

Free surface reports came from three sources, Ref 5, Round Robin reports and CDR's. Ref. 5 mentions all the peak free surface data known up to 1973. Some of the data may not have been recorded elsewhere. One source, Roger Preston then at Sandia collected hard-to-get data over the years. This reference does not give the specifics of where the gage was located on the surface. It was apparently close enough to the SGZ to be a representative measurement for peak surface velocity.

The new spreadsheet mentions the Pathfinder reports, which are free surface measurements, made at one underground test to the surface of another. Although these are free field they are usually at a considerable distance from the event being detonated. They are not in the free field column.

Round Robin measurements are from separate event reports and consisted of an array of 2 or more surface gages. One of the gages is close to the emplacement hole and represents a peak surface measurement. These reports give the time series traces and could be digitized. The tapes may reside at Sandia. It is possible that some of the data is in digital form and stored on the old photostore system. Much of the old memory system is still available in its reincarnated form on recent storage devices. Hopefully, all the LLNL related data have been transcribed to CD's.

The CDR's represent LLNL events spanning a time from 1977 to the end of testing in 1992. The CDR's include time series traces in each report but are conveniently available in digital form on CD's. I went through each report and entered the horizontal distance to the surface gages in the free field column. Usually, the closest gage was placed 50' from the center of the emplacement hole. I also entered RTP for gages in the ground at the Recording Trailer Park (RTP). However, it was not entered if the gage was in a trailer in the trailer park. The CDR reference in the free field column refers to the full named report located on the same row in the analysis column.

The number of subsurface gages were entered, the recording organization, the gage type (ground motion or stress) and the orientation to the WP. The orientation labeled offset-vertical for instrument and satellite holes and horizontal shot-level for events that had shot-level gages in separate holes or tunnel drifts. Some mention of vertical gages was used in ref. 4 but the difference between vertical and vertical offset was not defined. In many cases the orientation was not known and a (ONI) was added to indicate that the Orientation was Not Investigated, e.g. (ONI). The orientation will be shown in the original data reports. The information on subsurface gages came from references 4, 5, 6, and the CDR's. This data is all from LLNL events with instrumentation provided by EG\&G. The CDR's mention when free field data was not 
taken and I added this comment to the free field column. However, the comment really means that free field data was not the intention of the instrumentation. There were ground motion gages placed in plugs. LLNL found on the QUESO event ${ }^{7}$ that the plug data gave good results of the free field. Figure 1 shows the comparison of plug to particle velocity to instrument hole gages at the same radial range from the WP. I included the number of plug ground motion gages in the free field column. Occasionally, special gages from the instrument hole were mentioned. These were free field but were intended for peak measurements.

\section{WHAT HAS YET TO BE DONE}

If a thorough spreadsheet of all available data of both ground motion and containment diagnostics, is the final goal, then a number additional items need to be searched and added.

1. Add the LANL free field data from their ground motion data base ${ }^{8,9}$.

2. Make a though search through the event files in the T1406 vault for ground motion documentation not on the spreadsheet. LLNL free field data from 1974 to 1977 is not in the free field column in the spreadsheet

3. Add the missing free field, free surface, and LLNL containment diagnostics reports to the spreadsheet.

4. Add to the analysis column, calculation reports that were compared to the ground motion. Most of this information is in the event files. Some of the information is in the Containment Symposium documents.

5. Add more of the reference material that cover more than one event. Bass (1993), the CFRD Perret and Bass report, and Perret and Bass Revisited are examples, and I am sure there are others. These are located in the ground motion files in the vault (southwest wall, shelf 3 or 4 from bottom) and in the Containment Library (see the CL spreadsheet for "Ground Motion, Scaled Data" location in CL).

6. Add a column that shows the availability of actual digital data, the location of raw tapes, the location of paper records, and the possible fact that the data is no longer available. Some of this data could come from Jeff Wagoner's spreadsheet.

7. Add Jeff Wagoner's spreadsheet to this spreadsheet.

8. Fill in the date of event column and add a DOB column.

9. Go through DOD, DNA, and ARPA reports in search of any other missing ground motion information. The tunnel events after 1987 are likely candidates because reference 5 ends at this date.

10. Retrieve reports to find missing data or Not Investigated (NI) items on the spreadsheet. Specifically, items labeled ONI or NI.

11. Add subsurface gage radial locations relative to the WP and depth distance from the surface.

12. Add metric units.

\section{SUMMARY}

One could go on about corrections and data to add but in its current form the spreadsheet points to a reasonable large amount of free field and free surface data with 
some indication of the organization that took and reported the data. I found the following summary information from the spreadsheet. Of the 381 events on the spreadsheet, 164 events have free surface data, 69 events have free field data, and 44 events have gages in plugs. We have digital CD information on 189 events. The three highest free surface velocity non-crater events are CANNIKIN, TYBO, and HALFBEAK.

Information retrieval projects such as this tend to follow what I call "the $80 \%$ rule". It takes a certain amount of time $(\mathrm{X})$ to provide $80 \%$ of the total value of the data set. It takes the same $X$ amount of time to provide $80 \%$ of the $20 \%$ left to do and so on. The last parts of the complete data set become more and more difficult to find or verify. In this case $\mathrm{X}$ is about 2 weeks.

More details of the spreadsheet and an abbreviation table are provided in the appendix.

\section{AKNOWLEGEMENT}

I wish to acknowledge the LLNL D\&NT Containment Program. It has taken a great deal of effort and money to organize and continually store the information that is available in this spreadsheet. The Containment Program requests that you also acknowledge contributions to your projects, reports, or proposals when using this data. I wish to thank Gayle Pawloski for supporting some of this effort. I also donated 8 hours of my personal time to write this report after the fiscal year ended.

This work was performed under the auspices of the U.S. Department of Energy by the University of California, Lawrence Livermore National Laboratory under Contract No. W-7405-Eng-48.

\section{REFERENCES}

1."Initial Mapping of Containment Diagnostic Data and As-Built Information in Rm. 1113 of T1406", J. Rambo, Internal LLNL Memo, 5/13/98. With spreadsheet enclosure "Room 1113 Sp Meas. Map"

2."Re-mapping of Containment Diagnostic Data and As-built Information in Rm. 1113, the Containment Library, and Vault of T1406", J. Rambo, Internal LLNL Memorandum, 10/4/99, with spreadsheet enclosure "Room 1113/CL Event Map 10/99 2"

3. CFRD report "Peak Surface Velocity from Nuclear Explosions (U)", V. E. Wheeler, UOPBA 73-44, 3/16/73.

4.CFRD report "Summary of Free Field Ground Motion Measurements (U)", V. E. Wheeler/ R. G. Preston, UOPBA 74-126, 8/21/74, (V). 
5. CFRD report "Ground Shock Predictions for Underground Nuclear Explosions in Rainier Mesa (U)", L. F. Ingram, J. L. Drake, DNA-TR-88-14, 10/23/87.

6."Free-Field Ground Motion Induced by Underground Explosions", W. R. Perret, and R. C. Bass, SAND74-0252, Sandia Laboratories, 11/72.

7."QUESO Containment Data Report", T. Stubbs, and R. Heinle, UCRL-ID-121259, $5 / 95$.

DETAILS [for Ground Motion Data Appendix 3 (John Rambo)]

Column A

Event Name

Column B

Hole Identification

Column C

Comments - includes event sponsor, pre BANEBERRY, gages

below water table, gages in dolomite, carbonate, granite, non NTS locations.

Column D Early LLNL processed data. Work performed by Preston and Wheeler on containment diagnostics. It consists of hard copy processed data and engineering reports. (LLNL Events prior to 1977).

Column E Containment Diagnostics and ground motion - EG\&G processed data as CD's and notebooks (LLNL Events after 1977).

Column F Later data processing at LLNL by EG\&G. Pre event information and analysis information related to T. Stubbs data processing effort.

Column G Data plots on hard copy data rolls which include surface and subsurface ground motion.

Column $\mathrm{H} \quad$ Surface ground motion distance from SGZ.

Column I Event data comparisons and analysis which include multiple events.

Column J Summary and final reports which include ground motion analysis.

Column K Gage locations for free surface and free field gages - number of gages at surface, the horizontal distance, fielding organization, and reference information.

Number of subsurface free field gages, type of gages, fielding organization, and reference information. References refer mostly to report citations in columns I and $\mathrm{J}$. 


$\begin{array}{ll}\text { ABBREVIATIONS } \\ \text { PI } & \text { Physics International } \\ \text { SRI } & \text { Stanford Research International } \\ \text { WES } & \text { Waterway Experiment Station } \\ \text { NI } & \text { Not Investigated } \\ \text { DNA } & \text { Defense Nuclear Agency } \\ \text { DOD } & \text { Department of Defense } \\ \text { ONI } & \text { Orientation of gages subsurface - not investigated } \\ \text { RR } & \text { Round Robin Program reports. } \\ \text { CDR } & \text { Containment Data Report } \\ \text { RTP } & \text { Recording Trailer Park - The location for some free surface gages. } \\ \text { POR } & \text { Project Officers Report } \\ \text { WT } & \text { Weapons Test report } \\ \text { GM } & \text { Ground Motion }\end{array}$




\section{Appendix 3B}

(Attached as excel spreadsheet)

\section{John Rambo}

This spreadsheet shows the existence of free field ground motion data and the inclusion of some containment diagnostics. The information is stored in the LLNL DNT Containment Program Libraries. To access data see Gayle Pawloski or John Rambo. 
Ground Motion Data: Appendix 3B (John Rambo)

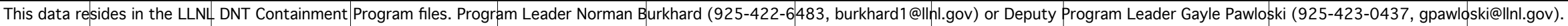

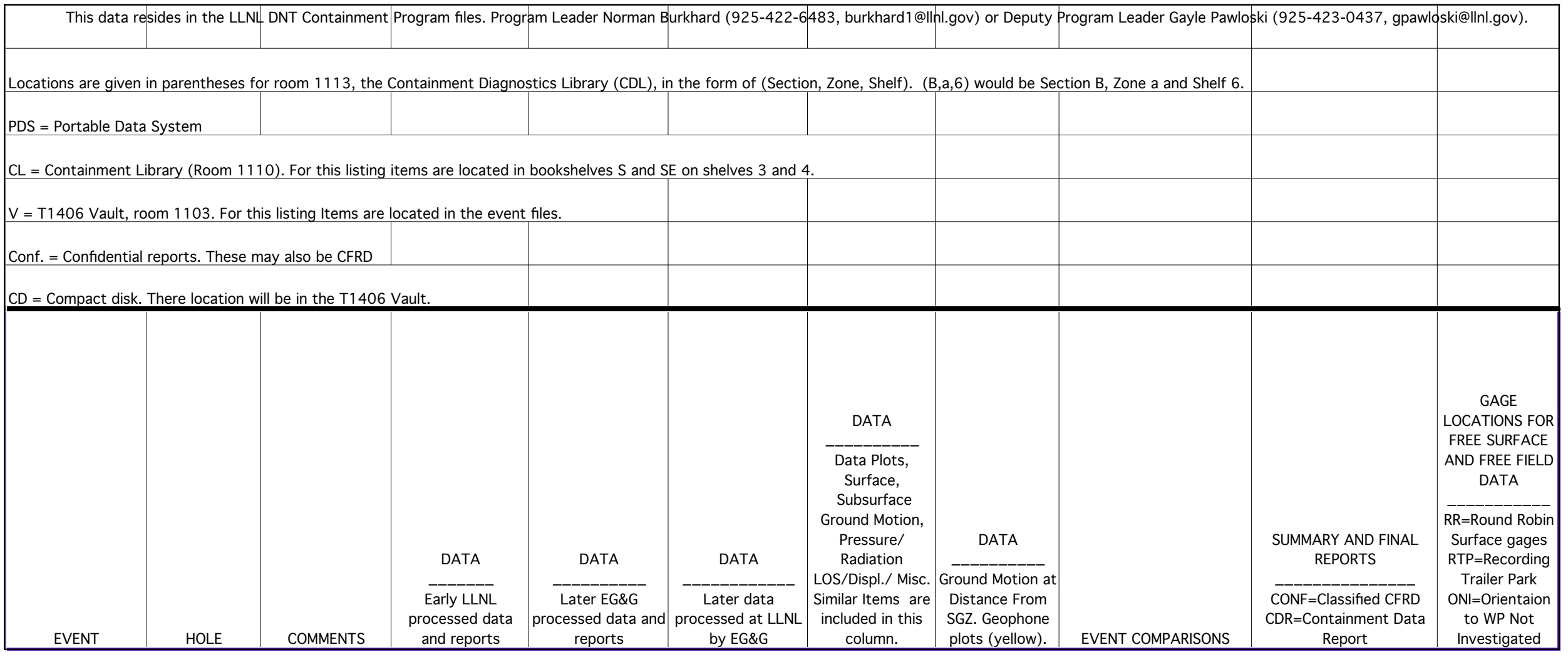


Ground Motion Data: Appendix 3B (John Rambo)

\begin{tabular}{|c|c|c|c|c|c|c|c|c|c|c|}
\hline This o & HOLE & 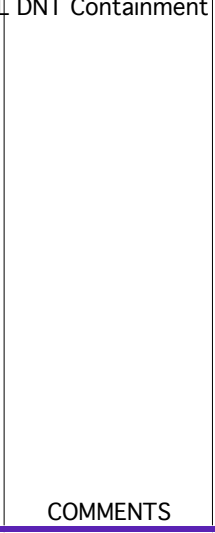 & $\begin{array}{c}\text { DATA } \\
\text { Early LLNL } \\
\text { processed data } \\
\text { and reports }\end{array}$ & $\begin{array}{c}\text { DATA } \\
\text { Later EG\&G } \\
\begin{array}{c}\text { processed data and } \\
\text { reports }\end{array}\end{array}$ & $\begin{array}{c}\text { DATA } \\
- \text { Later data } \\
\begin{array}{c}\text { processed at LLNL } \\
\text { by EG\&G }\end{array}\end{array}$ & $\begin{array}{c}\text { DATA } \\
\text { - Data Plots, } \\
\text { Surface, } \\
\text { Subsurface } \\
\text { Ground Motion, } \\
\text { Pressure/ } \\
\text { Radiation } \\
\text { LOS/Displ./ Misc. } \\
\text { Similar Items are } \\
\text { included in this } \\
\text { column. }\end{array}$ & $\begin{array}{c}\text { DATA } \\
\text { Ground Motion at } \\
\text { Distance From } \\
\text { SGZ. Geophone } \\
\text { plots (yellow). }\end{array}$ & EVENT COMPARISONS & $\begin{array}{c}\text { SUMMARY AND FINAL } \\
\text { REPORTS } \\
\text { CONF=Classified CFRD } \\
\text { CDR=Containment Data } \\
\text { Report }\end{array}$ & $\begin{array}{l}\text { GAGE } \\
\text { LOCATIONS FOR } \\
\text { FREE SURFACE } \\
\text { AND FREE FIELD } \\
\text { DATA } \\
\text { RR=Round Robin } \\
\text { Surface gages } \\
\text { RTP=Recording } \\
\text { Trailer Park } \\
\text { ONI=Orientaion } \\
\text { to WP Not } \\
\text { Investigated }\end{array}$ \\
\hline AGILE & U2v & $\begin{array}{l}\text { LLNL, Pre- } \\
\text { BANEBERRY, } 3 \\
\text { free field gages in } \\
\text { tuff below the } \\
\text { water table, } 1 \\
\text { free field gage in } \\
\text { carbonate }\end{array}$ & None & None & None & $\begin{array}{l}12 \text { Ground } \\
\text { Motion Playback } \\
\text { Rolls in Box }\end{array}$ & Pathfinder I & $\begin{array}{l}\text { Binder G, and CFRD report } \\
\text { "Ground Shock Predictions } \\
\text { for Underground Nuclear } \\
\text { Explosions in Rainier Mesa } \\
\text { (U)", L. F. Ingram, J. L. } \\
\text { Drake, DNA-TR-88-14, } \\
10 / 23 / 87 \text {. Unclassified } \\
\text { report "Free-Field Ground } \\
\text { Motion Induced by } \\
\text { Underground Explosions", } \\
\text { W. R. Perret, and R. C. } \\
\text { Bass, SAND74-0252, } \\
\text { Sandia Laboratories, } \\
11 / 72 . \text { CFRD report } \\
\text { "Summary of Free Field } \\
\text { Ground Motion } \\
\text { Measurments(U)", V. E. } \\
\text { Wheeler/ R. G. Preston, } \\
\text { UOPBA 74-126, 8/21/74. } \\
\text { CFRD report "Peak Surface } \\
\text { Velocity from Nuclear } \\
\text { Explosions (U)", V. E. } \\
\text { Wheeler, UOPBA 73-44, } \\
\text { 3/16/73, }\end{array}$ & $\begin{array}{l}\text { CFRD report "Comparison } \\
\text { of a Two-Layered Model } \\
\text { Calculation of AGILE with } \\
\text { Obsevations; Projection of } \\
\text { the Model to CREW } \\
\text { (U)",R. G. Preston and V. } \\
\text { E. Wheeler, UOPKG 68-3, } \\
\text { 2/9/68, . CFRD report } \\
\text { "Corrections to LRL } \\
\text { Memos, Ser UOPKG 68-3 } \\
\text { and UOPKG 68-3 } \\
\text { Addendum (U)", V.E. } \\
\text { Wheeler/R. G. Preston, } \\
\text { UOPKG 68-9, 3/21/68, . } \\
\text { Sandia, unreported } \\
\end{array}$ & $\begin{array}{l} \\
\text { Surface, Hor. } \\
\text { dist. (NI) (Ref. } \\
\text { UOPBA 73-44); } \\
\text { Subsurface, } 1 \\
\text { shot level GM } \\
\text { gage, } 5 \text { offset } \\
\text { verticle GM } \\
\text { gages, } 10 \\
\text { verticle GM } \\
\text { gages. (Ref. } \\
\text { UOPBA 74-126) }\end{array}$ \\
\hline AGOUTI & U3ad & $\begin{array}{l}\text { LANL, Pre- } \\
\text { BANEBERRY }\end{array}$ & None & None & None & None & None & $\begin{array}{l}\text { Celocity from Nuclear } \\
\text { Explosions (U)", V. E. } \\
\text { Wheeler, UOPBA 73-44, } \\
3 / 16 / 73 \text {, }\end{array}$ & 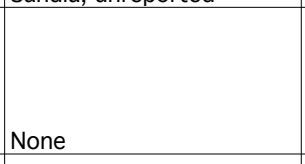 & $\begin{array}{l}\text { Hor. dist. (NI) } \\
\text { (Ref. UOPBA 73- } \\
\text { 44) } \\
\text { SUIIace, MUIIL. }\end{array}$ \\
\hline AGRINI & U2ev & LLNL & None & $\begin{array}{l}\text { CD of Compressed } \\
\text { Raw \& Processed } \\
\text { Data }\end{array}$ & 1 Folder & $\begin{array}{l}4 \text { Pipe and Hose } \\
\text { CLIPER Data } \\
\text { Listings in Box }\end{array}$ & None & $\begin{array}{l}\text { Binder X, Binder T } \\
\text { (CLIPER/EXCOR), } 3 \\
\text { Presentation Binders }\end{array}$ & $\begin{array}{l}\text { "AGRINI: Containment } \\
\text { Related Measurements } \\
\text { and Conclusions" UCRL } \\
53725 \text {; UCRL-ID-128934 } \\
\text { (CDR) }\end{array}$ & $\begin{array}{l}\text { Dist. 50' (Ref. } \\
\text { CDR): } \\
\text { Subsurface, No } \\
\text { free field gages, } \\
3 \text { GM gages in } \\
\text { Plugs (Ref. CDR) }\end{array}$ \\
\hline AJAX & U9al & $\begin{array}{l}\text { Light (LOS) Pipe, } \\
\text { LLNL, LLNL, Pre- } \\
\text { BANEBERRY }\end{array}$ & None & $\begin{array}{l}\text { CD of Compressed } \\
\text { Raw \& Processed } \\
\text { Data }\end{array}$ & None & $\begin{array}{l}4 \text { LOS Related } \\
\text { Data Roles } \\
\text { (Green) }\end{array}$ & None & None & None & \\
\hline
\end{tabular}


Ground Motion Data: Appendix 3B (John Rambo)

\begin{tabular}{|c|c|c|c|c|c|c|c|c|c|c|}
\hline 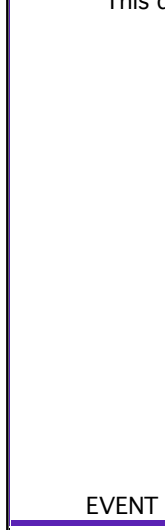 & HOLE & COMMENTS & (1) & $\begin{array}{c}\text { DATA } \\
\begin{array}{c}\text { Later EG\&G } \\
\text { processed data and } \\
\text { reports }\end{array} \\
\end{array}$ & $\begin{array}{c}\text { DATA } \\
- \text { Later data } \\
\begin{array}{c}\text { processed at LLNL } \\
\text { by EG\&G }\end{array}\end{array}$ & \begin{tabular}{|c|} 
DATA \\
Data Plots, \\
Surface, \\
Subsurface \\
Ground Motion, \\
Pressure/ \\
Radiation \\
LOS/Displ./ Misc. \\
Similar Items are \\
included in this \\
column.
\end{tabular} & \begin{tabular}{|c|} 
DATA \\
Ground Motion at \\
Distance From \\
SGZ. Geophone \\
plots (yellow).
\end{tabular} & 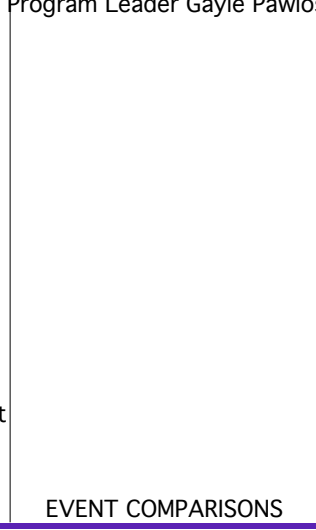 & $\begin{array}{c}\text { SUMMARY AND FINAL } \\
\text { REPORTS } \\
\text { CONF=Classified CFRD } \\
\text { CDR=Containment Data } \\
\text { Report }\end{array}$ & $\begin{array}{c}\text { GAGE } \\
\text { LOCATIONS FOR } \\
\text { FREE SURFACE } \\
\text { AND FREE FIELD } \\
\text { DATA } \\
\text { RR=Round Robin } \\
\text { Surface gages } \\
\text { RTP=Recording } \\
\text { Trailer Park } \\
\text { ONI=Orientaion } \\
\text { to WP Not } \\
\text { Investigated }\end{array}$ \\
\hline AKAVI & U2es & LLNL & None & $\begin{array}{l}\text { CD of Compressed } \\
\text { Raw \& Processed } \\
\text { Data }\end{array}$ & 1 Folder & $\begin{array}{l}4 \text { Ground Motion } \\
\text { Rolls (Blue) }\end{array}$ & None & None & $\begin{array}{l}\text { Draft Report "Final Data } \\
\text { Report: Surface Motion } \\
\text { from the AKAVI Event" ; } \\
\text { UCRL-ID-122069 (CDR) }\end{array}$ & \begin{tabular}{|l|} 
Surface, Horiz. \\
Dist. 50' 14 \\
gage surface \\
array, See report \\
(Ref. CDR): \\
Subsurface, No \\
free field gages, \\
No GM gages in \\
Plugs (Ref. CDR)
\end{tabular} \\
\hline AKBAR & U10ax & LLNL & 4 Binders & $\begin{array}{l}\text { CD of Compressed } \\
\text { Raw \& Processed } \\
\text { Data }\end{array}$ & 1 Folder & None & \begin{tabular}{|l|} 
\\
CNSI report \\
"Round Robin \\
Program AKBAR \\
Event (U)", W. R. \\
Perret, Sandia \\
UOPBA 72-156, \\
12/7/72 (V). \\
\end{tabular} & $\begin{array}{l}\text { report "Peak Surface } \\
\text { Velocity from Nuclear } \\
\text { Explosions (U)", V. E. } \\
\text { Wheeler, UOPBA 73-44, } \\
3 / 16 / 73, . \text { CFRD report } \\
\text { "Summary of Free Field } \\
\text { Ground Motion } \\
\text { Measurements (U)", V. E. } \\
\text { Wheeler/ R. G. Preston, } \\
\text { UOPBA 74-126, 8/21/74, } \\
\end{array}$ & $\begin{array}{l}\text { CFRD report "Response of } \\
\text { the Pinex Pipe and } \\
\text { Stemming in AKBAR (U)", } \\
\text { V. E. Wheeler/R. G. } \\
\text { Preston, UOPBA 73-184, } \\
10 / 24 / 73, \text {. CRD report } \\
\text { "Containment Diagnostics } \\
\text { on the AKBAR Event, } \\
\text { U10ax (U)", C. W. Olsen, } \\
\text { UOPBA 73-71, 5/3/73, }\end{array}$ & $\begin{array}{l}\text { Surface, Horiz., } \\
50^{\prime}, 438 ', 438 ', \\
437 ' . \text { (Ref. RR); } \\
\text { Ground Motion } \\
\text { can in the } \\
\text { surface casing. } \\
\text { Subsurface, } \\
\text { stemming gages } \\
\text { (Ref. UOPBA 74- } \\
126)\end{array}$ \\
\hline ALGODONES & U3jn & LANL & None & None & None & None & None & $\begin{array}{l}\text { Velocity from Nuclear } \\
\text { Wheeler, UOPBA } 73-44 \text {, } \\
3 / 16 / 73 \text {, }\end{array}$ & None & $\begin{array}{l}\text { Surface, Hor. } \\
\text { dist. (NI) (Ref. } \\
\text { UOPBA 73-44) }\end{array}$ \\
\hline ALMENDRO & U19v & LANL & None & None & None & None & Earth Strain Cals. & None & None & \\
\hline ALUMROOT & U9cj & LLNL & None & None & None & None & None & Binder F (CEP Related) & None & \\
\hline ALVA & U2j & $\begin{array}{l}\text { LLNL, Pre- } \\
\text { BANEBERRY }\end{array}$ & None & None & None & None & $\begin{array}{l}1 \text { Geophone Roll } \\
\text { (Yellow) }\end{array}$ & None & None & \\
\hline ANTLER & U12e.03 & $\begin{array}{l}\text { LLNL, Pre- } \\
\text { BANEBERRY } \\
\end{array}$ & None & None & None & None & None & $\begin{array}{l}\text { Velocity from Nuclear } \\
\text { Explosions (U)", V. E. } \\
\text { Wheeler, UOPBA } 73-44 \text {, } \\
3 / 16 / 73 \text {, }\end{array}$ & None & $\begin{array}{l}\text { Surface, Hor. } \\
\text { dist. (NI) (Ref. } \\
\text { UOPBA 73-44) }\end{array}$ \\
\hline
\end{tabular}


Ground Motion Data: Appendix 3B (John Rambo)

\begin{tabular}{|c|c|c|c|c|c|c|c|c|c|c|}
\hline This c & des in the & DNT Containme & $\begin{array}{c}\text { DATA } \\
\text { Early LLNL } \\
\text { processed data } \\
\text { and reports } \\
\end{array}$ & $\begin{array}{c}\text { DATA } \\
\text { Later EG\&G } \\
\begin{array}{c}\text { processed data and } \\
\text { reports }\end{array}\end{array}$ & $\begin{array}{c}\text { DATA } \\
-\begin{array}{c}\text { Later data } \\
\text { processed at LLNL } \\
\text { by EG\&G }\end{array}\end{array}$ & \begin{tabular}{|c|} 
DATA \\
Data Plots, \\
Surface, \\
Subsurface \\
Ground Motion, \\
Pressure/ \\
Radiation \\
LOS/Displ./ Misc. \\
Similar Items are \\
included in this \\
column.
\end{tabular} & $\begin{array}{c}\text { DATA } \\
\text { Ground Motion at } \\
\text { Distance From } \\
\text { SGZ. Geophone } \\
\text { plots (yellow). }\end{array}$ & Program Leader Gayle Pawlo & $\begin{array}{c}\text { SUMMARY AND FINAL } \\
\text { REPORTS } \\
\overline{\text { CONF=Classified CFRD }} \\
\text { CDR=Containment Data } \\
\text { Report }\end{array}$ & $\begin{array}{l}\text { ski@llnl.gov). } \\
\text { GAGE } \\
\text { LOCATIONS FOR } \\
\text { FREE SURFACE } \\
\text { AND FREE FIELD } \\
\text { DATA } \\
\text { RR=Round Robin } \\
\text { Surface gages } \\
\text { RTP=Recording } \\
\text { Trailer Park } \\
\text { ONI=Orientaion } \\
\text { to WP Not } \\
\text { Investigated }\end{array}$ \\
\hline APODACA & U3gs & LANL & None & None & None & None & $\begin{array}{l}\text { "Round Robin } \\
\text { Program } \\
\text { APODACA Event } \\
\text { (U)", W. R. } \\
\text { Perret, Sandia } \\
\text { UOPBA \#004, } \\
\text { 7/28/71 (V). } \\
\end{array}$ & $\begin{array}{l}\text { CFRD report "Peak Surface } \\
\text { Velocity from Nuclear } \\
\text { Explosions (U)", V. E. } \\
\text { Wheeler, UOPBA 73-44, } \\
3 / 16 / 73,\end{array}$ & None & $\begin{array}{l}\text { Surface (Ref. } \\
\text { RR) Horiz., 36', } \\
400^{\prime}\end{array}$ \\
\hline ARDVARK & U3am-S & $\begin{array}{l}\text { LANL, Pre- } \\
\text { BANEBERRY }\end{array}$ & None & None & None & None & None & $\begin{array}{l}\text { Velocity from Nuclear } \\
\text { Explosions (U)", V. E. } \\
\text { Wheeler, UOPBA 73-44, } \\
3 / 16 / 73 \text {, }\end{array}$ & None & $\begin{array}{l}\text { Surface, Hor. } \\
\text { dist. (NI) (Ref. } \\
\text { UOPBA 73-44) }\end{array}$ \\
\hline ARMADA & U9cs & LLNL & None & $\begin{array}{l}\text { CD of Compressed } \\
\text { Raw \& Processed } \\
\text { Data , CD of ASCII } \\
\text { Processed Data ; } 1 \\
\text { Binder }\end{array}$ & 1 Folder & $\begin{array}{l}1 \text { Ground Motion } \\
\text { Roll (Blue), } 1 \text { Roll } \\
\text { of Pres./ } \\
\text { Radiation Traces } \\
\text { (Red) }\end{array}$ & None & $\begin{array}{l}\text { Binder Y, Binder T } \\
\text { (CLIPER/EXCOR) }\end{array}$ & $\begin{array}{l}\text { Draft Report "Preliminary } \\
\text { Data Report: ARMADA } \\
\text { Motion, Pressure, and } \\
\text { Radiation" , UCRL-ID- } \\
125020 \text { (CDR) }\end{array}$ & $\begin{array}{l}\text { Dist. 50' (Ref. } \\
\text { CDR): } \\
\text { Subsurface, No } \\
\text { free field gages, } \\
2 \text { GM gages in } \\
\text { Plugs (Ref. CDR) }\end{array}$ \\
\hline ARMADILLO & U3ar & $\begin{array}{l}\text { LANL, Pre- } \\
\text { BANEBERRY }\end{array}$ & None & None & None & None & None & $\begin{array}{l}\text { Velocity from Nuclear } \\
\text { Explosions (U)", V. E. } \\
\text { Wheeler, UOPBA 73-44, } \\
3 / 16 / 73 \text {, }\end{array}$ & None & $\begin{array}{l}\text { Surface, Hor. } \\
\text { dist. (NI) (Ref. } \\
\text { UOPBA 73-44) }\end{array}$ \\
\hline ARSENATE & U9ci & LLNL & 6 Binders & $\begin{array}{l}\text { CD of Compressed } \\
\text { Raw \& Processed } \\
\text { Data }\end{array}$ & 1 Folder & None & \begin{tabular}{|l|} 
CNSI report \\
"Round Robin \\
Program \\
ARSENATE Event \\
(U)", W. R. \\
Perret, Sandia \\
UOPBA 72-157, \\
12/7/72 (V). \\
\end{tabular} & $\begin{array}{l}\text { Binders B, F, H. CFRD } \\
\text { report "Peak Surface } \\
\text { Velocity from Nuclear } \\
\text { Explosions (U)", V. E. } \\
\text { Wheeler, UOPBA 73-44, } \\
\text { 3/16/73, }\end{array}$ & $\begin{array}{l}\text { CFRD report "Coupling } \\
\text { Efficiency and the } \\
\text { Estimated Yield of } \\
\text { ARSENATE from Free Field } \\
\text { Ground Motions }(U) ", \text { V. } \\
\text { E. Wheeler/ R. G. Preston, } \\
\text { UOPBA } 73-12,2 / 1 / 73\end{array}$ & $\begin{array}{l}\text { Surface (Ref. } \\
\text { RR) Horiz.,50', } \\
375,375,375^{\prime}, \\
\text { Subsurface in } \\
\text { Satellite Hole, } \\
\text { Range, 230', } \\
2466^{\prime}, 291 ' \text { ', and } \\
319^{\prime}\end{array}$ \\
\hline ASCO & U10bc & LLNL & None & $\begin{array}{l}\text { CD of Compressed } \\
\text { Raw \& Processed } \\
\text { Data }\end{array}$ & None & None & None & None & None & \\
\hline ASIAGO & U2ar & LLNL & None & $\begin{array}{l}\text { CD of Compressed } \\
\text { Raw \& Processed } \\
\text { Data } \\
\end{array}$ & None & None & Earth Strain Cals. & None & $\begin{array}{l}\text { "Data Report for the } \\
\text { Containment Diagnostics } \\
\text { on ASIAGO, U2ar", UOPBA } \\
77-38\end{array}$ & \\
\hline
\end{tabular}


Ground Motion Data: Appendix 3B (John Rambo)

\begin{tabular}{|c|c|c|c|c|c|c|c|c|c|c|}
\hline This data & les in the LLNL & 4 DNT Containme & $\begin{array}{c}\text { DATA } \\
\text { Early LLNL } \\
\text { processed data } \\
\text { and reports }\end{array}$ & \begin{tabular}{|c|} 
DATA \\
$\begin{array}{c}\text { Later EG\&G } \\
\text { processed data and } \\
\text { reports }\end{array}$ \\
\end{tabular} & $\begin{array}{c}\text { DATA } \\
\text { Later data } \\
\begin{array}{c}\text { processed at LLNL } \\
\text { by EG\&G }\end{array}\end{array}$ & \begin{tabular}{|c|} 
DATA \\
Data Plots, \\
Surface, \\
Subsurface \\
Ground Motion, \\
Pressure/ \\
Radiation \\
LOS/Displ./ Misc. \\
Similar Items are \\
included in this \\
column. \\
\end{tabular} & \begin{tabular}{|c|} 
DATA \\
Ground Motion at \\
Distance From \\
SGZ. Geophone \\
plots (yellow).
\end{tabular} & Program Leader Gayle Pawlo & $\begin{array}{c}\text { SUMMARY AND FINAL } \\
\text { REPORTS } \\
\text { CONF=Classified CFRD } \\
\text { CDR=Containment Data } \\
\text { Report }\end{array}$ & $\begin{array}{l}\text { ski@llnl.gov). } \\
\text { GAGE } \\
\text { LOCATIONS FOR } \\
\text { FREE SURFACE } \\
\text { AND FREE FIELD } \\
\text { DATA } \\
\text { RR=Round Robin } \\
\text { Surface gages } \\
\text { RTP=Recording } \\
\text { Trailer Park } \\
\text { ONI=Orientaion } \\
\text { to WP Not } \\
\text { Investigated } \\
\end{array}$ \\
\hline $\begin{array}{l}\text { ATARQUE } \\
\text { AVENSALKERMES }\end{array}$ & U3ht & LANL & None & None & None & None & $\begin{array}{l}\text { "Round Robin } \\
\text { Program } \\
\text { ATATQUE Event } \\
\text { (U)", W. R. } \\
\text { Perret, Sandia } \\
\text { UOPBA 72-90, } \\
\text { 8/10/72 (V). } \\
\end{array}$ & $\begin{array}{l}\text { CFRD report "Peak Surface } \\
\text { Velocity from Nuclear } \\
\text { Explosions (U)", V. E. } \\
\text { Wheeler, UOPBA 73-44, } \\
3 / 16 / 73 \text {, }\end{array}$ & None & $\begin{array}{l}\text { Surface (Ref. } \\
\text { RR) Horiz., 51', } \\
487^{\prime}, 487^{\prime}, 486^{\prime}\end{array}$ \\
\hline $\begin{array}{l}\text { AVENS ANDORRE } \\
\text { AVENS ASMALTE } \\
\text { AVENS CREAM }\end{array}$ & $\begin{array}{l}\text { U9I U-24 U9I T- } \\
28 \text { U9I W-21 } \\
\text { U9I X-29 }\end{array}$ & $\begin{array}{l}\text { LLNL, Pre- } \\
\text { BANEBERRY }\end{array}$ & None & None & None & None & None & 1 Presentation Binder & None & \\
\hline AZUL & U2em & LLNL & None & $\begin{array}{l}\text { CD of Compressed } \\
\text { Raw \& Processed } \\
\text { Data; CD of ASCII } \\
\text { Processed Data; } 1 \\
\text { Binder }\end{array}$ & 1 Folder & None & \begin{tabular}{|l|}
1 \\
Geophone Roll, $\&$ \\
1 Regular Roll \\
(Yellow)
\end{tabular} & $\begin{array}{l}\text { Binder U (Peak } \\
\text { Accelleration of Trailers), } 1 \\
\text { Presentation Binder }\end{array}$ & $\begin{array}{l}\text { Draft Report "Motion of } \\
\text { the Stemming and } \\
\text { Emplacement Pipe from } \\
\text { the AZUL Event" , UCRL- } \\
\text { ID-127719 (CDR) }\end{array}$ & $\begin{array}{l}\text { Dist. 50' (Ref. } \\
\text { CDR): } \\
\text { Subsurface, No } \\
\text { free field gages, } \\
3 \text { GM gages in } \\
\text { Plugs (Ref. CDR) }\end{array}$ \\
\hline BACKBEACH & U19x & LANL & None & $\begin{array}{l}\text { CD of Compressed } \\
\text { Raw \& Processed } \\
\text { Data }\end{array}$ & None & None & None & None & None & \\
\hline BACKSWING & U9aw & $\begin{array}{l}\text { LLNL, Pre- } \\
\text { BANEBERRY }\end{array}$ & None & None & None & None & $\begin{array}{l}1 \text { Geophone Roll } \\
\text { (Yellow) }\end{array}$ & & None & \\
\hline BALTIC & U9IS 25 & $\begin{array}{l}\text { May also be } \\
\text { reffered to as } \\
\text { NAMA BALTIC } \\
\text { Event }\end{array}$ & None & None & None & None & None & $\begin{array}{l}\text { CFUD report "reak surtace } \\
\text { Velocity from Nuclear } \\
\text { Explosions (U)", V. E. } \\
\text { Wheeler, UOPBA } 73-44, \\
3 / 16 / 73\end{array}$ & None & $\begin{array}{l}\text { Surface (Ref. } \\
\text { RR) Horiz., 50' }\end{array}$ \\
\hline
\end{tabular}


Ground Motion Data: Appendix 3B (John Rambo)

\begin{tabular}{|c|c|c|c|c|c|c|c|c|c|c|}
\hline 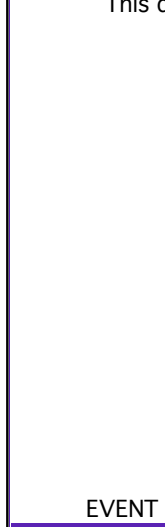 & HOLE & COMMENTS & $\begin{array}{l}\text { DATA } \\
\text { Early LLNL } \\
\text { processed data } \\
\text { and reports }\end{array}$ & $\begin{array}{c}\text { DATA } \\
- \text { Later EG\&G } \\
\text { processed data and } \\
\text { reports }\end{array}$ & $\begin{array}{c}\text { DATA } \\
- \text { Later data } \\
\text { processed at LLNL } \\
\text { by EG\&G }\end{array}$ & \begin{tabular}{|c|} 
DATA \\
Data Plots, \\
Surface, \\
Subsurface \\
Ground Motion, \\
Pressure/ \\
Radiation \\
LOS/Displ./ Misc. \\
Similar Items are \\
included in this \\
column.
\end{tabular} & $\begin{array}{c}\text { DATA } \\
\text { Ground Motion at } \\
\text { Distance From } \\
\text { SGZ. Geophone } \\
\text { plots (yellow). }\end{array}$ & 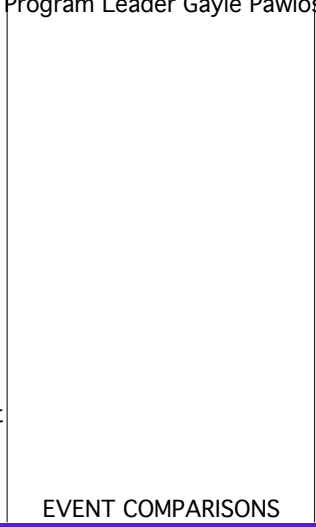 & $\begin{array}{c}\text { SUMMARY AND FINAL } \\
\text { REPORTS } \\
\text { CONF=Classified CFRD } \\
\text { CDR=Containment Data } \\
\text { Report }\end{array}$ & $\begin{array}{l}\text { GAII InI.gOV). } \\
\text { GAGE } \\
\text { LOCATIONS FOR } \\
\text { FREE SURFACE } \\
\text { AND FREE FIELD } \\
\text { DATA } \\
\text { RR=Round Robin } \\
\text { Surface gages } \\
\text { RTP=Recording } \\
\text { Trailer Park } \\
\text { ONI=Orientaion } \\
\text { to WP Not } \\
\text { Investigated }\end{array}$ \\
\hline BANEBERRY & U8d & BANEBERRY & 5 Binders & $\begin{array}{l}\text { CD of Compressed } \\
\text { Raw \& Processed } \\
\text { Data }\end{array}$ & None & None & $\begin{array}{l}1 \text { Wide } \\
\text { Geophone Roll } \\
\text { (Yellow) }\end{array}$ & \begin{tabular}{|l|} 
Binders E, L, O, and CFRD \\
report "Trapped Stress \\
Waves in Underground \\
Nuclear Explosions (U)", V. \\
E. Wheeler, R. G. Preston, \\
C. E. Frerking, UCRL- \\
52012, . CFRD report \\
"Summary of Free Field \\
Ground Motion \\
Measurments(U)", V. E. \\
Wheeler/ R. G. Preston, \\
UOPBA 74-126, 8/21/74. \\
\end{tabular} & $\begin{array}{l}\text { BANEBERRY Free Surface } \\
\text { Motion:, Joseph R. Hearst, } \\
\text { UCON 71-1, 5/17/71, }\end{array}$ & $\begin{array}{l}\text { Surface, } 16 \mathrm{~mm} \\
\text { film playback of } \\
\text { videotape from } \\
\text { camera \#1, } \\
\text { located 2000' } \\
\text { west and south } \\
\text { of SGZ. } \\
\text { Subsurface, } \\
\text { stemming gages } \\
\text { (Ref. UOPBA 74- } \\
\text { 126) } \\
\end{array}$ \\
\hline BANON & U2dz & LLNL & None & $\begin{array}{l}\text { CD of Compressed } \\
\text { Raw \& Processed } \\
\text { Data }\end{array}$ & None & None & \begin{tabular}{|l|} 
Earth Strain Cals. \\
Pathfinder II
\end{tabular} & None & $\begin{array}{l}\text { for the Containment } \\
\text { Diagnostics on BANON, } \\
\text { U2dz", UOPBA 76-161 }\end{array}$ & \\
\hline BARNWELL & U20az & LLNL & 1 Binder & $\begin{array}{l}\text { CD of Compressed } \\
\text { Raw \& Processed } \\
\text { Data; CD of ASCII } \\
\text { Processed Data; } 1 \\
\text { LLNL Data Binder; } \\
1 \text { LANL Data } \\
\text { Binder } \\
\end{array}$ & 2 Folders & None & None & $\begin{array}{l}\text { Binder T (CLIPER/EXCOR), } \\
2 \text { Presentation Binders }\end{array}$ & MISC-5035 (CDR) & $\begin{array}{l}\text { Dist. 50', 992', } \\
1970 ' \text { (Ref. } \\
\text { CDR): } \\
\text { Subsurface, No } \\
\text { free field gages, } \\
\text { No GM gages in } \\
\text { Plugs (Ref. CDR) } \\
\end{array}$ \\
\hline BELLOW & U4ac & LLNL & None & None & 1 Folder & None & None & None & None & \\
\hline BELMONT & U20as & LLNL & None & $\begin{array}{l}\text { CD of Compressed } \\
\text { Raw \& Processed } \\
\text { Data; CD of ASCII } \\
\text { Processed Data;1 } \\
\text { Binder }\end{array}$ & 1 Folder & CLIPER Printout & None & $\begin{array}{l}\text { Binder U (Peak } \\
\text { Accelleration of Trailers), } 2 \\
\text { Presentation Binders }\end{array}$ & \begin{tabular}{|l|} 
\\
"Containment Diagnostics \\
Report for BELMONT, \\
U2Oas" UOPKL 87-2
\end{tabular} & $\begin{array}{l}\text { Dist. 50', RTP } \\
\text { gage is 50' from } \\
\text { trailer \#985 } \\
\text { (Ref. CDR): } \\
\text { Subsurface, No } \\
\text { free field gages, } \\
\text { No GM gages in } \\
\text { Plugs (Ref. CDR) }\end{array}$ \\
\hline BENHAM & U20c & $\begin{array}{l}\text { LLNL, Pre- } \\
\text { BANEBERRY }\end{array}$ & None & None & None & None & $\begin{array}{l}2 \text { Geophone Rolls } \\
\text { (Yellow) }\end{array}$ & 1 Presentation Binder & (2) & \\
\hline BILLET & U7an & LANL & None & None & None & None & Earth Strain Cals. & None & None & \\
\hline
\end{tabular}


Ground Motion Data: Appendix 3B (John Rambo)

\begin{tabular}{|c|c|c|c|c|c|c|c|c|c|c|}
\hline 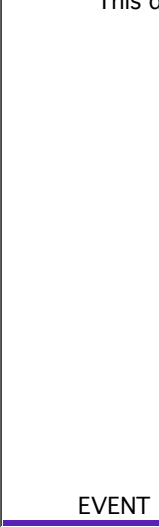 & HOLE & COMMENTS & $\begin{array}{c}\text { DATA } \\
\text { Early LLNL } \\
\text { processed data } \\
\text { and reports }\end{array}$ & $\mid \begin{array}{c}\text { DATA } \\
\begin{array}{c}\text { Later EG\&G } \\
\text { processed data and } \\
\text { reports }\end{array}\end{array}$ & $\begin{array}{c}\text { DATA } \\
- \text { Later data } \\
\begin{array}{c}\text { processed at LLNL } \\
\text { by EG\&G }\end{array}\end{array}$ & \begin{tabular}{|c} 
DATA \\
- Data Plots, \\
Surface, \\
Subsurface \\
Ground Motion, \\
Pressure/ \\
Radiation \\
LOS/Displ./ Misc. \\
Similar Items are \\
included in this \\
column.
\end{tabular} & $\begin{array}{l}\text { DATA } \\
\text { Ground Motion at } \\
\text { Distance From } \\
\text { SGZ. Geophone } \\
\text { plots (yellow). }\end{array}$ & 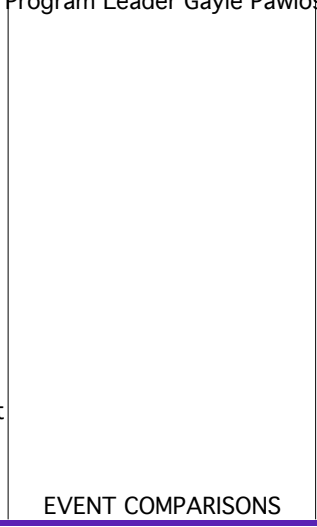 & $\begin{array}{c}\text { SUMMARY AND FINAL } \\
\text { REPORTS } \\
\text { CONF=Classified CFRD } \\
\begin{array}{c}\text { CDR=Containment Data } \\
\text { Report }\end{array}\end{array}$ & $\begin{array}{l}\text { GAGE } \\
\text { LOCATIONS FOR } \\
\text { FREE SURFACE } \\
\text { AND FREE FIELD } \\
\text { DATA } \\
\text { RR=Round Robin } \\
\text { Surface gages } \\
\text { RTP=Recording } \\
\text { Trailer Park } \\
\text { ONI=Orientaion } \\
\text { to WP Not } \\
\text { Investigated }\end{array}$ \\
\hline BODIE & U20ap & LLNL & None & \begin{tabular}{|l|} 
CD of Compressed \\
Raw \& Processed \\
Data; CD of ASCII \\
Processed Data;1 \\
Binder
\end{tabular} & 2 Folders & $\begin{array}{l}2 \text { CLIPER List } 1 \\
\text { Grnd Motion Roll } \\
\text { (Blue), } 4 \text { Pres./ } \\
\text { Rad. (Volts) } \\
\text { Printout Rolls } \\
\text { (Red), } 2 \text { Pres./ } \\
\text { Rad. (Conv. to } \\
\text { Units) Printout } \\
\text { Rolls (Red), } 1 \\
\text { Pres./ Rad. and } \\
\text { Accel. Traces on } \\
\text { Roll (Red), } 2 \\
\text { Rolls/Boxes of } \\
\end{array}$ & $\begin{array}{l}1 \text { Geophone Roll } \\
\text { (Yellow) }\end{array}$ & $\begin{array}{l}\text { Binder W, Binder U (Peak } \\
\text { Accelleration of Trailers), } \\
\text { Binder T (CLIPER/EXCOR), } \\
4 \text { Presentation Binders } \\
\end{array}$ & UCRL-ID-117558 (CDR) & $\begin{array}{l}\text { Surface, Horiz. } \\
\text { Dist. 50' (Ref. } \\
\text { CDR): } \\
\text { Subsurface, No } \\
\text { free field gages, } \\
\text { No GM gages in } \\
\text { Plugs (Ref. CDR) }\end{array}$ \\
\hline BONARDA & U3gv & LANL & None & None & None & None & $\begin{array}{l}\text { Pathinder CD } \\
\text { with interaction } \\
\text { measurment } \\
\text { made at RIOLA }\end{array}$ & None & None & \\
\hline BORATE & U2ge & LLNL & None & \begin{tabular}{|l|} 
CD of Compressed \\
Raw \& Processed \\
Data; CD of ASCII \\
Processed Data;1 \\
Binder
\end{tabular} & 1 Folder & $\begin{array}{l}1 \text { Pres./ Radiation } \\
\text { Printout Role } \\
\text { (Red) }\end{array}$ & None & $\begin{array}{l}\text { Binder W, Binder U (Peak } \\
\text { Accelleration of Trailers), } 1 \\
\text { Presentation Binder }\end{array}$ & UCRL-ID-117557 (CDR) & $\begin{array}{l}\text { Dist. 50', RTP } \\
\text { (Ref. CDR): } \\
\text { Subsurface, No } \\
\text { free field gages, } \\
1 \text { GM gage in } \\
\text { Plug (Ref. CDR) }\end{array}$ \\
\hline BOXCAR & $\mathrm{U} 20 \mathrm{~g}$ & $\begin{array}{l}\text { LLNL, Pre- } \\
\text { BANEBERRY }\end{array}$ & None & None & None & None & None & $\begin{array}{l}\text { Velocity from Nuclear } \\
\text { Explosions (U)", V. E. } \\
\text { Wheeler, UOPBA 73-44, } \\
3 / 16 / 73, \text {. CFRD report } \\
\text { "Summary of Free Field } \\
\text { Ground Motion } \\
\text { Measurements (U)", V. E. } \\
\text { Wheeler/ R. G. Preston, } \\
\text { UOPBA 74-126, 8/21/74, } \\
\end{array}$ & Sandia, unreported & $\begin{array}{l}\text { Surface, Hor. } \\
\text { dist. (NI) (Ref. } \\
\text { UOPBA 73-44); } \\
\text { Subsurface, } 7 \\
\text { shot level GM } \\
\text { gages (Ref. } \\
\text { UOPBA 74-126). }\end{array}$ \\
\hline
\end{tabular}


Ground Motion Data: Appendix 3B (John Rambo)

\begin{tabular}{|c|c|c|c|c|c|c|c|c|c|c|}
\hline This o & des in the & DNT Containm & $\begin{array}{c}\text { DATA } \\
\text { Early LLNL } \\
\text { processed data } \\
\text { and reports }\end{array}$ & $\begin{array}{c}\text { DATA } \\
\begin{array}{c}\text { Later EG\&G } \\
\text { processed data and } \\
\text { reports }\end{array}\end{array}$ & $\begin{array}{c}\text { DATA } \\
\text { Later data } \\
\begin{array}{c}\text { processed at LLNL } \\
\text { by EG\&G }\end{array}\end{array}$ & $\begin{array}{c}\text { DATA } \\
\text { Data Plots, } \\
\text { Surface, } \\
\text { Subsurface } \\
\text { Ground Motion, } \\
\text { Pressure/ } \\
\text { Radiation } \\
\text { LOS/Displ./ Misc. } \\
\text { Similar Items are } \\
\text { included in this } \\
\text { column. }\end{array}$ & $\begin{array}{c}\text { DATA } \\
\text { Ground Motion at } \\
\text { Distance From } \\
\text { SGZ. Geophone } \\
\text { plots (yellow). }\end{array}$ & Program Leader Gayle Paw & $\begin{array}{c}\text { SUMMARY AND FINAL } \\
\text { REPORTS } \\
\text { CONF=Classified CFRD } \\
\begin{array}{c}\text { CDR=Containment Data } \\
\text { Report }\end{array} \\
\end{array}$ & $\begin{array}{l}\text { oski@|lnl.gov). } \\
\text { GAGE } \\
\text { LOCATIONS FOR } \\
\text { FREE SURFACE } \\
\text { AND FREE FIELD } \\
\text { DATA } \\
\text { RR=Round Robin } \\
\text { Surface gages } \\
\text { RTP=Recording } \\
\text { Trailer Park } \\
\text { ONl=Orientaion } \\
\text { to WP Not } \\
\text { Investigated }\end{array}$ \\
\hline BRACKEN & U10aq & LLNL & 5 Binders & $\begin{array}{l}\text { CD of Compressed } \\
\text { Raw \& Processed } \\
\text { Data }\end{array}$ & 1 Folder & None & None & $\begin{array}{l}\text { Binders B, H, P, and CFRD } \\
\text { report "Summary of Free } \\
\text { Field Ground Motion } \\
\text { Measurments(U)", V. E. } \\
\text { Wheeler/ R. G. Preston, } \\
\text { UOPBA 74-126, 8/21/74. }\end{array}$ & $\begin{array}{l}\text { the Containment } \\
\text { Diagnostics on BRACKEN } \\
\text { (U)", C. W. Olsen, UOPBA } \\
71-155,11 / 20 / 71, . \\
\text { CONF report "Surface- } \\
\text { Motion Measurements in } \\
\text { BRACKEN and LAGOON } \\
\text { (U)", R. G. Preston and V. } \\
\text { E. Wheeler, UOPBA } 72-10 \text {, } \\
\text { 2/23/72,. }\end{array}$ & $\begin{array}{l} \\
\text { Surface Horiz. } \\
\text { Dist. 44', 985' } \\
\text { (Ref. UOPBA 72- } \\
\text { 10); Subsurface } \\
10 \text { (ONI) GM } \\
\text { gages (Ref. } \\
\text { UOPBA 74-126) } \\
\text { Jul IaU, , IIIIL. }\end{array}$ \\
\hline BRANCO & U2ew & LLNL & None & \begin{tabular}{|l|} 
CD of Compressed \\
Raw \& Processed \\
Data; CD of ASCII \\
Processed Data;1 \\
Binder
\end{tabular} & 1 Folder & None & None & Binder T (CLIPER/EXCOR) & $\begin{array}{l}\text { Draft Report "Special } \\
\text { Measurements on the } \\
\text { BRANCO Event: } \\
\text { Preliminary Report"; UCRL- } \\
\text { ID-125019 (CDR) }\end{array}$ & $\begin{array}{l}\text { Dist. 50' (Ref. } \\
\text { CDR): } \\
\text { Subsurface, No } \\
\text { free field gages, } \\
1 \text { GM gage in } \\
\text { Plug (Ref. CDR) } \\
\end{array}$ \\
\hline BRETON & U4ar & LLNL & None & \begin{tabular}{|l|} 
CD of Compressed \\
Raw \& Processed \\
Data; CD of ASCII \\
Processed Data; 1 \\
Binder
\end{tabular} & & \begin{tabular}{|l|}
4 Ground Motion \\
Rolls (Blue), 3 \\
Rolls of Pres./ \\
Radiation Traces \\
(Red) \\
\end{tabular} & None & $\begin{array}{l}\text { Binder X, Binder U (Peak } \\
\text { Accelleration of Trailers), } \\
\text { Binder T (CLIPER/EXCOR), } \\
3 \text { Presentation Binders } \\
\end{array}$ & $\begin{array}{l}\text { Draft Report "Post-shot } \\
\text { Measurements on } \\
\text { BRETON, Hole U4ar" ; } \\
\text { MISC-8685 (CDR) } \\
\end{array}$ & $\begin{array}{l}\text { Dist. 50', 632', } \\
1106 ', 1584 ', \\
3173 ', 4753^{\prime}, \\
7498 ', 10985^{\prime} \\
\text { (Ref. CDR): } \\
\text { Subsurface, No } \\
\text { free field gages, } \\
4 \text { GM gages in } \\
\text { Plugs (Ref. CDR) } \\
\end{array}$ \\
\hline
\end{tabular}


Ground Motion Data: Appendix 3B (John Rambo)

\begin{tabular}{|c|c|c|c|c|c|c|c|c|c|c|}
\hline 更 & HOLE & COMMENTS & $\begin{array}{c}\text { DATA } \\
\text { Early LLNL } \\
\text { processed data } \\
\text { and reports }\end{array}$ & $\begin{array}{c}\text { DATA } \\
- \text { Later EG\&G } \\
\begin{array}{c}\text { processed data and } \\
\text { reports }\end{array}\end{array}$ & $\begin{array}{c}\text { DATA } \\
\text { Later data } \\
\begin{array}{c}\text { processed at LLNL } \\
\text { by EG\&G }\end{array}\end{array}$ & \begin{tabular}{|c} 
DATA \\
- Data Plots, \\
Surface, \\
Subsurface \\
Ground Motion, \\
Pressure/ \\
Radiation \\
LOS/Displ./ Misc. \\
Similar Items are \\
included in this \\
column.
\end{tabular} & $\begin{array}{l}\text { DATA } \\
\text { Ground Motion at } \\
\text { Distance From } \\
\text { SGZ. Geophone } \\
\text { plots (yellow). }\end{array}$ & 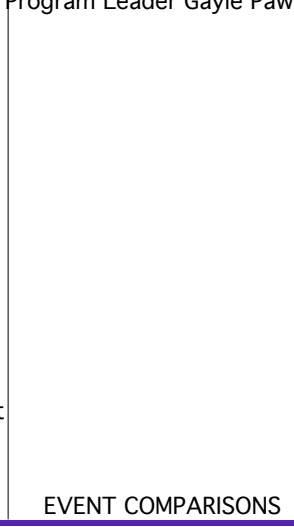 & $\begin{array}{c}\text { REPORTS } \\
\text { SUMMARY AND FINAL } \\
\text { REPONF=Classified CFRD } \\
\text { CONF } \\
\text { CDR=Containment Data } \\
\text { Report }\end{array}$ & $\begin{array}{l}\text { GAGE } \\
\text { LOCATIONS FOR } \\
\text { FREE SURFACE } \\
\text { AND FREE FIELD } \\
\text { DATA } \\
\text { RR=Round Robin } \\
\text { Surface gages } \\
\text { RTP=Recording } \\
\text { Trailer Park } \\
\text { ONI=Orientaion } \\
\text { to WP Not } \\
\text { Investigated }\end{array}$ \\
\hline BRIE & U10cc & LLNL & None & 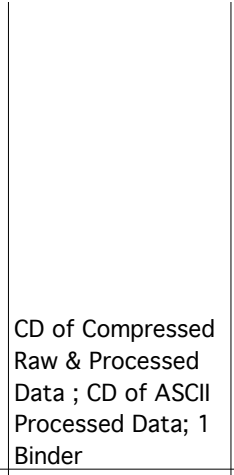 & 2 Folders & $\begin{array}{l}1 \text { Pres./ Radiation } \\
\text { Printout Roll } \\
\text { (Volts) } \text { (Red) }\end{array}$ & None & 2 Presentation Binders & UCRL-ID-120651 (CDR) & \begin{tabular}{|l|} 
Surface, Horiz. \\
Dist. 50', 12 \\
gage surface \\
array, See report \\
for horiz. \\
distances (Ref. \\
CDR): \\
Subsurface, Free \\
field gages, 7 \\
vertical offset \\
GM gages, 6 \\
vertical offset \\
stress gages, No \\
GM gages in \\
Plugs (Ref. CDR) \\
\end{tabular} \\
\hline BRISTOL & U4av & LLNL & None & \begin{tabular}{|l|} 
CD of Compressed \\
Raw \& Processed \\
Data; CD of ASCII \\
Processed Data;1 \\
Binder
\end{tabular} & 2 Folders & None & None & None & UCRL-MI-111974 (CDR) & $\begin{array}{l}\text { Surface, Horiz. } \\
\text { Dist. 50', RTP } \\
\text { (Ref. CDR): } \\
\text { Subsurface, No } \\
\text { free field gages, } \\
3 \text { experimental } \\
\text { stress gages, } 8 \\
\text { optical part. } \\
\text { velocity gages, } 3 \\
\text { ASM Part. } \\
\text { velocity gages } \\
\text { (Peak only), No } \\
\text { GM gages in }\end{array}$ \\
\hline BULKHEAD & U7am & LANL & None & None & None & None & $\begin{array}{l}\text { Earth Strain Cals. } \\
\text {. Pathfinder CD } \\
\text { of Compressed } \\
\text { Raw \& Processed } \\
\text { Data (V) }\end{array}$ & None & None & \\
\hline
\end{tabular}


Ground Motion Data: Appendix 3B (John Rambo)

\begin{tabular}{|c|c|c|c|c|c|c|c|c|c|c|}
\hline This o & HOLE & DNI Contanme & rogram mes. prog & $\begin{array}{c}\text { DATA } \\
\begin{array}{c}\text { Later EG\&G } \\
\text { processed data and } \\
\text { reports }\end{array} \\
\end{array}$ & \begin{tabular}{|c} 
DATA \\
Later data \\
$\begin{array}{c}\text { processed at LLNL } \\
\text { by EG\&G }\end{array}$
\end{tabular} & \begin{tabular}{|c|} 
DATA \\
Data Plots, \\
Surface, \\
Subsurface \\
Ground Motion, \\
Pressure/ \\
Radiation \\
LOS/Displ./ Misc. \\
Similar Items are \\
included in this \\
column. \\
\end{tabular} & \begin{tabular}{|c|} 
DATA \\
Ground Motion at \\
Distance From \\
SGZ. Geophone \\
plots (yellow).
\end{tabular} & (l) & $\begin{array}{c}\text { SUMMARY AND FINAL } \\
\text { REPORTS } \\
-\overline{\text { CONF=Classified CFRD }} \\
\text { CDR=Containment Data } \\
\text { Report }\end{array}$ & $\begin{array}{c}\text { Gski@llnl.gov). } \\
\text { GAGE } \\
\text { LOCATIONS FOR } \\
\text { FREE SURFACE } \\
\text { AND FREE FIELD } \\
\text { DATA } \\
\text { RR=Round Robin } \\
\text { Surface gages } \\
\text { RTP=Recording } \\
\text { Trailer Park } \\
\text { ONI=Orientaion } \\
\text { to WP Not } \\
\text { Investigated } \\
\end{array}$ \\
\hline BULLFROG & U4au & LLNL & None & $\begin{array}{l}\text { CD of Compressed } \\
\text { Raw \& Processed } \\
\text { Data; CD of ASCII } \\
\text { Processed Data;1 } \\
\text { Binder } \\
\end{array}$ & 1 Folder & None & None & $\begin{array}{l}\text { Binder W, Binder T } \\
\text { (CLIPER/EXCOR), } 1 \\
\text { Presentation Binder }\end{array}$ & MISC-4648 (CDR) & $\begin{array}{l}\text { Dist. 50', 830', } \\
1655^{\prime} \text { (Ref. } \\
\text { CDR): } \\
\text { Subsurface, No } \\
\text { free field gages, } \\
\text { No GM gages in } \\
\text { Plugs (Ref. CDR) }\end{array}$ \\
\hline BULLION & U20bd & LLNL & None & $\begin{array}{l}\text { CD of Compressed } \\
\text { Raw \& Processed } \\
\text { Data; CD of ASCII } \\
\text { Processed Data;1 } \\
\text { Binder }\end{array}$ & 2 Folders & None & None & $\begin{array}{l}\text { Binder T (CLIPER/EXCOR), } \\
2 \text { Presentation Binders }\end{array}$ & UCRL-MI-104746 (CDR) & $\begin{array}{l}\text { Surface, No } \\
\text { Horiz. Gages } \\
\text { (Ref. CDR): } \\
\text { Subsurface, No } \\
\text { free field gages, } \\
\text { no GM gages in } \\
\text { Plugs, (Ref. CDR) }\end{array}$ \\
\hline BURZET & U4ai & LLNL & None & $\begin{array}{l}\text { CD of Compressed } \\
\text { Raw \& Processed } \\
\text { Data; CD of ASCII } \\
\text { Processed Data;1 } \\
\text { Binder }\end{array}$ & 1 Folder & $\begin{array}{l}1 \text { Wide Ground } \\
\text { Motion Roll (Blue) }\end{array}$ & None & None & UCRL-ID-129058（CDR） & $\begin{array}{l}\text { Surface, Horiz. } \\
\text { Dist. 35' (Ref. } \\
\text { CDR): } \\
\text { Subsurface, Free } \\
\text { field gages, } 10 \\
\text { vertical offset } \\
\text { GM gages, } 8 \\
\text { vertical offset } \\
\text { stress gages, No } \\
\text { GM gages in } \\
\text { Plugs (Ref. CDR) }\end{array}$ \\
\hline CABOC & $\mathrm{U} 2 \mathrm{cp}$ & LLNL & None & $\begin{array}{l}\text { CD of Compressed } \\
\text { Raw \& Processed } \\
\text { Data ; CD of ASCII } \\
\text { Processed Data ; } \\
\text { Binder }\end{array}$ & 1 Folder & $\begin{array}{l}1 \text { Ground Motion } \\
\text { Roll (Blue) }\end{array}$ & None & $\begin{array}{l}\text { Binder U (Peak } \\
\text { Accelleration of Trailers), } \\
\text { Binder T (CLIPER/EXCOR), } \\
\text { Binder S (SMIDS Collapse } \\
\text { Signals), } 1 \text { Presentation } \\
\text { Binder }\end{array}$ & $\begin{array}{l}\text { Draft Report "Strong } \\
\text { Motion Measured on the } \\
\text { CABOC Event" ; } \\
\text { "Containment Analysis for } \\
\text { CABOC Nuclear Event" } \\
\text { UCRL } 53275 \text { (Conf. ); } \\
\text { Draft Report } \\
\text { "Containment Analysis for } \\
\text { CABOC Nuclear Event" ; } \\
\text { UCRL-ID-125021 (CDR) } \\
\end{array}$ & $\begin{array}{l} \\
\text { Surface, Horiz. } \\
\text { Dist. 50' (Ref. } \\
\text { CDR): } \\
\text { Subsurface, No } \\
\text { free field gages, } \\
4 \text { GM gages in } \\
\text { Plugs (Ref. CDR) }\end{array}$ \\
\hline
\end{tabular}


Ground Motion Data: Appendix 3B (John Rambo)

\begin{tabular}{|c|c|c|c|c|c|c|c|c|c|c|}
\hline 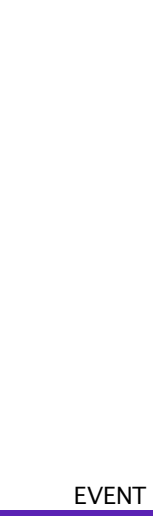 & HOLE & COMMENTS & $\begin{array}{c}\text { DATA } \\
\text { Early LLNL } \\
\text { processed data } \\
\text { and reports }\end{array}$ & $\begin{array}{c}\text { DATA } \\
\begin{array}{c}\text { Later EG\&G } \\
\text { processed data and } \\
\text { reports }\end{array} \\
\end{array}$ & $\begin{array}{c}\text { DATA } \\
-\begin{array}{c}\text { Later data } \\
\text { processed at LLNL } \\
\text { by EG\&G }\end{array}\end{array}$ & \begin{tabular}{|c} 
DATA \\
Data Plots, \\
Surface, \\
Subsurface \\
Ground Motion, \\
Pressure/ \\
Radiation \\
LOS/Displ./ Misc. \\
Similar Items are \\
included in this \\
column.
\end{tabular} & $\begin{array}{l}\text { DATA } \\
\text { Ground Motion at } \\
\text { Distance From } \\
\text { SGZ. Geophone } \\
\text { plots (yellow). }\end{array}$ & EVENT COMPARISONS & $\begin{array}{c}\text { SUMMARY AND FINAL } \\
\text { REPORTS } \\
\text { CONF=Classified CFRD } \\
\text { CDR=Containment Data } \\
\text { Report }\end{array}$ & \begin{tabular}{|c} 
GAGE \\
LOCATIONS FOR \\
FREE SURFACE \\
AND FREE FIELD \\
DATA \\
RR=Round Robin \\
Surface gages \\
RTP=Recording \\
Trailer Park \\
ONI=Orientaion \\
to WP Not \\
Investigated
\end{tabular} \\
\hline CABRA & U20aj & LLNL & None & $\begin{array}{l}\text { CD of Compressed } \\
\text { Raw \& Processed } \\
\text { Data; CD of ASCII } \\
\text { Processed Data; } 1 \\
\text { Binder }\end{array}$ & 1 Folder & $\begin{array}{l}1 \text { Wide Ground } \\
\text { Motion Roll (Blue) }\end{array}$ & None & Binder T (CLIPER/EXCOR) & $\begin{array}{l}\text { "Preliminary Data Report: } \\
\text { Motion Measurements } \\
\text { From CABRA" UOPKL 83- } \\
41 \text {; Memo "CABRA } \\
\text { Ground Motion Photo } \\
\text { Flight" ; UCRL-ID-125018 } \\
\text { (CDR) }\end{array}$ & $\begin{array}{l}\text { Dist. 50', 400', } \\
800^{\prime}, 1200^{\prime}, \\
1600^{\prime} \text { (Ref. } \\
\text { CDR): } \\
\text { Subsurface, No } \\
\text { free field gages, } \\
2 \text { GM gages in } \\
\text { Plugs (Ref. CDR) }\end{array}$ \\
\hline CABRILLO & U2dr & LLNL & None & $\begin{array}{l}\text { CD of Compressed } \\
\text { Raw \& Processed } \\
\text { Data }\end{array}$ & None & None & $\begin{array}{l}\text { Earth Strain Cals. } \\
\text { Pathfinder II }\end{array}$ & None & None & \\
\hline CALABASH & U2av & $\begin{array}{l}\text { LLNL, Pre- } \\
\text { BANEBERRY, } 2 \\
\text { free field gages in } \\
\text { tuff below the } \\
\text { water table. }\end{array}$ & 3 Binders & 更 & 1 Folder & None & Pathfinder II & $\begin{array}{l}\text { report "Ground Shock } \\
\text { Predictions for } \\
\text { Underground Nuclear } \\
\text { Explosions in Rainier Mesa } \\
\text { (U)", L. F. Ingram, J. L. } \\
\text { Drake, DNA-TR-88-14, } \\
10 / 23 / 87 . \text { Unclassified } \\
\text { report "Free-Field Ground } \\
\text { Motion Induced by } \\
\text { Underground Explosions", } \\
\text { W. R. Perret, and R. C. } \\
\text { Bass, SAND74-0252, } \\
\text { Sandia Laboratories, } \\
11 / 72 \text {. CFRD report } \\
\text { "Summary of Free Field } \\
\text { Ground Motion } \\
\text { Measurements (U)", V. E. } \\
\text { Wheeler/ R. G. Preston, } \\
\text { UOPBA 74-126, 8/21/74, }\end{array}$ & $\begin{array}{l}\text { CFRD report "Preliminary } \\
\text { Report of the Response of } \\
\text { the Stemming in the } \\
\text { CALABASH Nuclear Test } \\
\text { (U)", V. E. Wheeler, D. A. } \\
\text { Dicke, and R. C. Preston, } \\
\text { EG\&G Albuquerque } \\
\text { Division Document ASD } \\
\text { 70-210, 6/26/70, . } \\
\text { Sandia/LLNL, unreported }\end{array}$ & $\begin{array}{l} \\
\\
\text { Surface 30', } \\
\text { Subsurface, } 5 \\
\text { GM gages (ONI) } \\
\text { (Ref. UOPBA 74- } \\
\text { 126) }\end{array}$ \\
\hline CAMBRIC & U5e & $\begin{array}{l}\text { LLNL, Pre- } \\
\text { BANEBERRY }\end{array}$ & None & & None & None & None & $\begin{array}{l}\text { Velocity from Nuclear } \\
\text { Explosions (U)", V. E. } \\
\text { Wheeler, UOPBA 73-44, } \\
3 / 16 / 73 \text {, }\end{array}$ & None & $\begin{array}{l}\text { Surface, Hor. } \\
\text { dist. (NI) (Ref. } \\
\text { UOPBA 73-44) }\end{array}$ \\
\hline CAMEMBERT & U19a & LLNL & None & $\begin{array}{l}\text { CD of Compressed } \\
\text { Raw \& Processed } \\
\text { Data }\end{array}$ & None & None & $\begin{array}{l}\text { Earth Strain Cals. } \\
\text { PDS Cals. }\end{array}$ & None & None & \\
\hline
\end{tabular}


Ground Motion Data: Appendix 3B (John Rambo)

\begin{tabular}{|c|c|c|c|c|c|c|c|c|c|c|}
\hline 更 & HOLE & 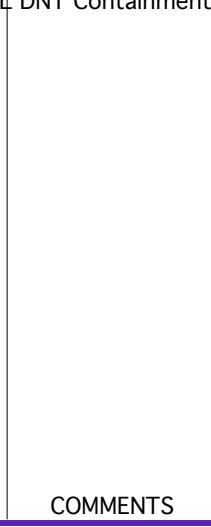 & $\begin{array}{c}\text { DATA } \\
\text { Early LLNL } \\
\text { processed data } \\
\text { and reports }\end{array}$ & $\begin{array}{c}\text { DATA } \\
\begin{array}{c}\text { Later EG\&G } \\
\text { processed data and } \\
\text { reports }\end{array}\end{array}$ & $\begin{array}{c}\text { DATA } \\
\text { Later data } \\
\begin{array}{c}\text { processed at LLNL } \\
\text { by EG\&G }\end{array}\end{array}$ & \begin{tabular}{|c} 
DATA \\
Data Plots, \\
Surface, \\
Subsurface \\
Ground Motion, \\
Pressure/ \\
Radiation \\
LOS/Displ./ Misc. \\
Similar Items are \\
included in this \\
column.
\end{tabular} & $\begin{array}{l}\text { DATA } \\
\text { Ground Motion at } \\
\text { Distance From } \\
\text { SGZ. Geophone } \\
\text { plots (yellow). }\end{array}$ & 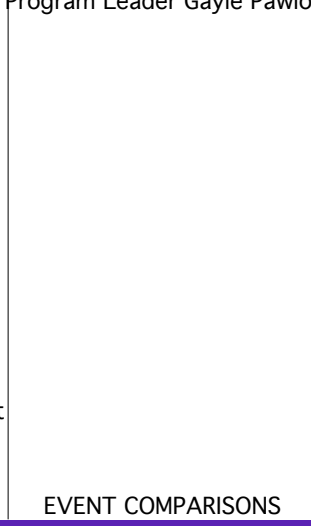 & $\begin{array}{c}\text { SUMMARY AND FINAL } \\
\text { REPORTS } \\
\text { CONF=Classified CFRD } \\
\begin{array}{c}\text { CDR=Containment Data } \\
\text { Report }\end{array}\end{array}$ & $\begin{array}{c}\text { GAGE } \\
\text { LOCATIONS FOR } \\
\text { FREE SURFACE } \\
\text { AND FREE FIELD } \\
\text { DATA } \\
\text { RR=Round Robin } \\
\text { Surface gages } \\
\text { RTP=Recording } \\
\text { Trailer Park } \\
\text { ONI=Orientaion } \\
\text { to WP Not } \\
\text { Investigated }\end{array}$ \\
\hline CAMPHOR & U12g.10 & LLL/SNL/DOD & None & & None & None & None & $\begin{array}{l}\text { CFRD report "Summary of } \\
\text { Free Field Ground Motion } \\
\text { Measurements (U)", V. E. } \\
\text { Wheeler/ R. G. Preston, } \\
\text { UOPBA 74-126, 8/21/74, } \\
\text {. CFRD report "Ground } \\
\text { Shock Predictions for } \\
\text { Underground Nuclear } \\
\text { Explosions in Rainier Mesa } \\
\text { (U)", L. F. Ingram, J. L. } \\
\text { Drake, DNA-TR-88-14, } \\
\text { 10/23/87, . }\end{array}$ & Sandia, unreported & $\begin{array}{l}\text { Subsurface: } 4 \\
\text { GM gages (ONI) } \\
\text { (Ref. UOPBA 74- } \\
\text { 126); } 7 \text { GM } \\
\text { gages, } 1 \text { stress } \\
\text { gage (ONI) (Ref. } \\
\text { DNA-TR-88-14) } \\
\end{array}$ \\
\hline CAMPOS & U9cp & $\begin{array}{l}\text { LLNL } \\
\text { UIIKIIUWII as LO }\end{array}$ & None & $\begin{array}{l}\text { CD of Compressed } \\
\text { Raw \& Processed } \\
\text { Data }\end{array}$ & None & None & None & Binder T (CLIPER/EXCOR) & None & \\
\hline $\begin{array}{l}\text { CAN GREEN or } \\
\text { CAN RED }\end{array}$ & $\begin{array}{l}\text { U2dd } 1 \text { or } \\
\text { U2dd } 4\end{array}$ & $\begin{array}{l}\text { which event, } \\
\text { perhaps both, } \\
\text { affected the data, } \\
\text { LLNL, Pre- } \\
\text { BANEBERRY }\end{array}$ & None & None & None & None & $\begin{array}{l}1 \text { Wide } \\
\text { Geophone Roll } \\
\text { (Yellow) }\end{array}$ & None & None & \\
\hline CANNA & U9IYZ 26 & LLNL & None & None & None & None & None & Binder $\mathrm{F}$ & None & \\
\hline CANNIKIN & UA 1 & $\begin{array}{l}\text { Amchitka Island, } \\
\text { Basalt, Most of } \\
23 \text { gages below } \\
\text { the water table. }\end{array}$ & 3 Binders & \begin{tabular}{|l|} 
CD of Compressed \\
Raw \& Processed \\
Data
\end{tabular} & 1 Folder & None & None & $\begin{array}{l}\text { Velocity from Nuclear } \\
\text { Explosions (U)", V. E. } \\
\text { Wheeler, UOPBA 73-44, } \\
3 / 16 / 73, \text {. CFRD report } \\
\text { "Summary of Free Field } \\
\text { Ground Motion } \\
\text { Measurements (U)", V. E. } \\
\text { Wheeler/ R. G. Preston, } \\
\text { UOPBA 74-126, 8/21/74, }\end{array}$ & $\begin{array}{l}\text { Sandia report SLA-73 } \\
\text { 0043. CFRD report } \\
\text { "Ground Motion Yield } \\
\text { Values for CANNIKIN (U)", } \\
\text { J. W. HADLEY, C. J. } \\
\text { Sisemore, M. Heusinkveld, } \\
\text { UCID-16074, 6/15/72, . }\end{array}$ & $\begin{array}{l}\text { Surface, Hor. } \\
\text { dist. (NI) (Ref. } \\
\text { UOPBA 73-44); } \\
\text { Subsurface,23 } \\
\text { vertical GM } \\
\text { gages. (Ref. } \\
\text { UOPBA 74-126) } \\
\end{array}$ \\
\hline
\end{tabular}


Ground Motion Data: Appendix 3B (John Rambo)

\begin{tabular}{|c|c|c|c|c|c|c|c|c|c|c|}
\hline This o & ides in th & DNT Containment & $\begin{array}{c}\text { DATA } \\
\text { Early LLNL } \\
\text { processed data } \\
\text { and reports }\end{array}$ & $\begin{array}{c}\text { DATA } \\
\begin{array}{c}\text { Later EG\&G } \\
\text { processed data and } \\
\text { reports }\end{array} \\
\end{array}$ & \begin{tabular}{|c} 
DATA \\
Later data \\
processed at LLNL \\
by EG\&G
\end{tabular} & \begin{tabular}{|c|} 
DATA \\
Data Plots, \\
Surface, \\
Subsurface \\
Ground Motion, \\
Pressure/ \\
Radiation \\
LOS/Displ./ Misc. \\
Similar Items are \\
included in this \\
column.
\end{tabular} & $\begin{array}{c}\text { DATA } \\
\text { Ground Motion at } \\
\text { Distance From } \\
\text { SGZ. Geophone } \\
\text { plots (yellow). }\end{array}$ & Program Leader Gayle Paw & $\begin{array}{c}\text { SUMMARY AND FINAL } \\
\text { REPORTS } \\
\text { CONF=Classified CFRD } \\
\text { CDR=Containment Data } \\
\text { Report }\end{array}$ & $\begin{array}{l}\text { ski@llnl.gov). } \\
\text { GAGE } \\
\text { LOCATIONS FOR } \\
\text { FREE SURFACE } \\
\text { AND FREE FIELD } \\
\text { DATA } \\
\text { RR=Round Robin } \\
\text { Surface gages } \\
\text { RTP=Recording } \\
\text { Trailer Park } \\
\text { ONl=Orientaion } \\
\text { to WP Not } \\
\text { Investigated }\end{array}$ \\
\hline CARNELIAN & U4af & LLNL & 1 Binder & $\begin{array}{l}\text { Raw \& Processed } \\
\text { Data; CD of ASCII } \\
\text { Processed Data; } 1 \\
\text { Binder Labeled } \\
\text { Wheeler, } 1 \text { Black } \\
\text { Binder With } \\
\text { Corrections, } \\
\end{array}$ & 1 Folder & None & None & & $\begin{array}{l}\text { Draft Report "CARNELIAN } \\
\text { Motion of the Plugs and } \\
\text { Emplacement of the Pipe" } \\
\text {; UCRL-ID-131332 (CDR) }\end{array}$ & $\begin{array}{l}\text { Surface, Horiz. } \\
\text { Dist. 50' (Ref. } \\
\text { CDR): } \\
\text { Subsurface, No } \\
\text { free field gages, } \\
3 \text { GM gages in } \\
\text { Plugs (Ref. CDR) } \\
\end{array}$ \\
\hline CARPETBAG & U2dg & $\begin{array}{l}\text { LLNL, Pre- } \\
\text { BANEBERRY, } 1 \\
\text { free field gage in } \\
\text { tuff below the } \\
\text { water table }\end{array}$ & $\begin{array}{l}4 \text { Binders and One } \\
\text { Small Black Binder }\end{array}$ & $\begin{array}{l}\text { CD of Compressed } \\
\text { Raw \& Processed } \\
\text { Data }\end{array}$ & None & None & $\begin{array}{l}\text { Pathfinder II ; } 1 \\
\text { Wide Geophone } \\
\text { Roll (Yellow) }\end{array}$ & $\begin{array}{l}\text { Free Field Ground Motion } \\
\text { Measurements (U)", V. E. } \\
\text { Wheeler/ R. G. Preston, } \\
\text { UOPBA 74-126, 8/21/74, } \\
\text {. CFRD report "Ground } \\
\text { Shock Predictions for } \\
\text { Underground Nuclear } \\
\text { Explosions in Rainier Mesa } \\
\text { (U)", L. F. Ingram, J. L. } \\
\text { Drake, DNA-TR-88-14, } \\
10 / 23 / 87 . \text { Unclassified } \\
\text { report "Free-Field Ground } \\
\text { Motion Induced by } \\
\text { Underground Explosions", } \\
\text { W. R. Perret, and R. C. } \\
\text { Bass, SAND74-0252, } \\
\text { Sandia Laboratories, } \\
11 / 72 .\end{array}$ & Sandia/LLNL, unreported & $\begin{array}{l}\text { Subsurface, } 4 \\
\text { GM gages (ONI) } \\
\text { (Ref. UOPBA 74- } \\
126)\end{array}$ \\
\hline & U2ad & \begin{tabular}{|l} 
LLNL, Pre- \\
BANEBERRY
\end{tabular} & None & None & None & None & Earth Strain Cals. & None & None & \\
\hline CATHAY & U9ch & & & $\begin{array}{l}\text { CD of Compressed } \\
\text { Raw \& Processed } \\
\text { Data }\end{array}$ & & None & $\begin{array}{l}\text { report "Round } \\
\text { Robin Program } \\
\text { CATHAY Event", } \\
\text { W. R. Perret, } \\
\text { Sandia No } \\
\text { document \#, } \\
8 / 27 / 71,(\mathrm{~V}) . \\
\end{array}$ & $\begin{array}{l}\text { Binders B, H, P. CFRD } \\
\text { report "Peak Surface } \\
\text { Velocity from Nuclear } \\
\text { Explosions (U)", V. E. } \\
\text { Wheeler, UOPBA 73-44, } \\
\text { 3/16/73, }\end{array}$ & & $\begin{array}{l}\text { Surface (Ref. } \\
\text { RR) Horiz., 56', } \\
619^{\prime}, 619^{\prime}, \\
620^{\prime} .\end{array}$ \\
\hline
\end{tabular}


Ground Motion Data: Appendix 3B (John Rambo)

\begin{tabular}{|c|c|c|c|c|c|c|c|c|c|c|}
\hline This d & des in the & DNT Containme & $\begin{array}{c}\text { DATA } \\
\text { Early LLNL } \\
\text { processed data } \\
\text { and reports } \\
\end{array}$ & $\begin{array}{c}\text { DATA } \\
\begin{array}{c}\text { Later EG\&G } \\
\text { processed data and } \\
\text { reports }\end{array}\end{array}$ & $\begin{array}{c}\text { DATA } \\
\text { Later data } \\
\begin{array}{c}\text { processed at LLNL } \\
\text { by EG\&G }\end{array}\end{array}$ & \begin{tabular}{|c} 
DATA \\
Data Plots, \\
Surface, \\
Subsurface \\
Ground Motion, \\
Pressure/ \\
Radiation \\
LOS/Displ./ Misc. \\
Similar Items are \\
included in this \\
column.
\end{tabular} & $\begin{array}{l}\text { DATA } \\
\text { Ground Motion at } \\
\text { Distance From } \\
\text { SGZ. Geophone } \\
\text { plots (yellow). }\end{array}$ & (1) & $\begin{array}{c}\text { SUMMARY AND FINAL } \\
\text { REPORTS } \\
\text { CONF=Classified CFRD } \\
\text { CDR=Containment Data } \\
\text { Report }\end{array}$ & $\begin{array}{l}\text { oski@|lnl.gov). } \\
\text { GAGE } \\
\text { LOCATIONS FOR } \\
\text { FREE SURFACE } \\
\text { AND FREE FIELD } \\
\text { DATA } \\
\text { RR=Round Robin } \\
\text { Surface gages } \\
\text { RTP=Recording } \\
\text { Trailer Park } \\
\text { ONI=Orientaion } \\
\text { to WP Not } \\
\text { Investigated }\end{array}$ \\
\hline CEBOLLA & U3jc & LANL & None & None & None & None & $\begin{array}{l}\text { "Round Robin } \\
\text { Program } \\
\text { CEBOLLA Event } \\
\text { (U)", W. R. } \\
\text { Perret, Sandia } \\
\text { UOPBA 72-102, } \\
\text { 8/29/72 (V). } \\
\end{array}$ & $\begin{array}{l}\text { CFRD report "Peak Surface } \\
\text { Velocity from Nuclear } \\
\text { Explosions (U)", V. E. } \\
\text { Wheeler, UOPBA 73-44, } \\
3 / 16 / 73 \text {, }\end{array}$ & None & $\begin{array}{l}\text { Surface Horiz., } \\
50^{\prime}, 480^{\prime}, 480^{\prime}, \\
480^{\prime} \text { (Ref. RR) }\end{array}$ \\
\hline CEBRERO & U9cw & LLNL & 1 Binder & $\begin{array}{l}\text { CD of Compressed } \\
\text { Raw \& Processed } \\
\text { Data ; CD of ASCII } \\
\text { Processed Data ;1 } \\
\text { Binder } \\
\end{array}$ & 1 Folder & None & None & $\begin{array}{l}\text { Binder X, Binder U (Peak } \\
\text { Accelleration of Trailers), } \\
5 \text { Presentation Binders }\end{array}$ & UCRL-ID-121262 (CDR) & $\begin{array}{l}\text { Dist. 50', RTP } \\
\text { (Ref. CDR): } \\
\text { Subsurface, No } \\
\text { free field gages, } \\
\text { No GM gages in } \\
\text { Plugs (Ref. CDR) }\end{array}$ \\
\hline CHAENACTIS & U2dl & LLNL & 2 Binders & $\begin{array}{l}\text { CD of Compressed } \\
\text { Raw \& Processed } \\
\text { Data }\end{array}$ & 1 Folder & None & None & $\begin{array}{l}\text { CFRD report "Trapped } \\
\text { Stress Waves in } \\
\text { Underground Nuclear } \\
\text { Explosions (U)", V. E. } \\
\text { Wheeler, R. G. Preston, C. } \\
\text { E. Frerking, UCRL-52012, . } \\
\text { CFRD report "Peak Surface } \\
\text { Velocity from Nuclear } \\
\text { Explosions (U)", V. E. } \\
\text { Wheeler, UOPBA 73-44, } \\
3 / 16 / 73,\end{array}$ & None & $\begin{array}{l}\text { Surface, Hor. } \\
\text { dist. (NI) (Ref. } \\
\text { UOPBA 73-44); } \\
\text { Subsurface } \\
\text { stemming gages. }\end{array}$ \\
\hline CHANCELLOR & U19ad & LANL & None & $\begin{array}{l}\text { CD of Compressed } \\
\text { Raw \& Processed } \\
\text { Data ; CD of ASCII } \\
\text { Processed Data ; } \\
\end{array}$ & None & None & None & None & None & \\
\hline CHANTILLY & U2di & LLNL & 1 Binder & $\begin{array}{l}\text { CD of Compressed } \\
\text { Raw \& Processed } \\
\text { Data }\end{array}$ & 1 Folder & None & $\begin{array}{l}\text { "Round Robin } \\
\text { Program } \\
\text { CHANTILLY } \\
\text { Event (U)", W. R. } \\
\text { Perret, Sandia } \\
\text { UOPBA \#003, } \\
\text { 10/27/71 (V). }\end{array}$ & $\begin{array}{l}\text { Binder B. CFRD report } \\
\text { "Peak Surface Velocity } \\
\text { from Nuclear Explosions } \\
\text { (U)", V. E. Wheeler, UOPBA } \\
73-44,3 / 16 / 73 \text {, }\end{array}$ & $\begin{array}{l}\text { CFRD report } \\
\text { "Containment Diagnostics } \\
\text { on the CHANTILLY Event } \\
\text { (U)", C. W. Olsen, UOPBA } \\
71-142,11 / 1 / 71 \text {, }\end{array}$ & $\begin{array}{l}\text { Surface (Ref. } \\
\text { RR) Horiz., 71', } \\
542 ', 542 ' .\end{array}$ \\
\hline CHATEAUGAY & U2Ot & $\begin{array}{l}\text { Pre-BANEBERRY, } \\
\text { LANL }\end{array}$ & None & None & None & None & $\begin{array}{l}8 \text { Geophone Rolls } \\
\text { (Yellow) }\end{array}$ & sone & None & \\
\hline
\end{tabular}


Ground Motion Data: Appendix 3B (John Rambo)

\begin{tabular}{|c|c|c|c|c|c|c|c|c|c|c|}
\hline This da & ides in the & DNT Containme & $\begin{array}{c}\text { DATA } \\
\text { Early LLNL } \\
\text { processed data } \\
\text { and reports }\end{array}$ & $\begin{array}{c}\text { DATA } \\
\text { Later EG\&G } \\
\begin{array}{c}\text { processed data and } \\
\text { reports }\end{array}\end{array}$ & $\begin{array}{c}\text { DATA } \\
-\begin{array}{c}\text { Later data } \\
\text { processed at LLNL } \\
\text { by EG\&G }\end{array}\end{array}$ & \begin{tabular}{|c} 
483, burkhard1@ @ll \\
DATA \\
Data Plots, \\
Surface, \\
Subsurface \\
Ground Motion, \\
Pressure/ \\
Radiation \\
LOS/Displ./ Misc. \\
Similar Items are \\
included in this \\
column.
\end{tabular} & \begin{tabular}{|c|} 
DATA \\
Ground Motion at \\
Distance From \\
SGZ. Geophone \\
plots (yellow).
\end{tabular} & Program Leader Gayle Pawlo & $\begin{array}{c}\text { SUMMARY AND FINAL } \\
\text { REPORTS } \\
\text { CONF=Classified CFRD } \\
\text { CDR=Containment Data } \\
\text { Report }\end{array}$ & $\begin{array}{l}\text { ski@|lnl.gov). } \\
\text { GAGE } \\
\text { LOCATIONS FOR } \\
\text { FREE SURFACE } \\
\text { AND FREE FIELD } \\
\text { DATA } \\
\text { RR=Round Robin } \\
\text { Surface gages } \\
\text { RTP=Recording } \\
\text { Trailer Park } \\
\text { ONl=Orientaion } \\
\text { to WP Not } \\
\text { Investigated }\end{array}$ \\
\hline CHEEDAM & U2et & LLNL & None & $\begin{array}{l}\text { CD of Compressed } \\
\text { Raw \& Processed } \\
\text { Data; CD of ASCII } \\
\text { Processed Data;1 } \\
\text { Binder }\end{array}$ & 1 Folder & None & None & $\begin{array}{l}\text { Binder Y, Binder T } \\
\text { (CLIPER/EXCOR) }\end{array}$ & $\begin{array}{l}\text { Draft Report "CHEEDAM } \\
\text { Motion, Pressure and } \\
\text { Radiation: Preliminary } \\
\text { Data Report"; UCRL-ID- } \\
125015 \text { (CDR) } \\
\end{array}$ & $\begin{array}{l}\text { Dist. 50' (Ref. } \\
\text { CDR): } \\
\text { Subsurface, No } \\
\text { free field gages, } \\
3 \text { GM gages in } \\
\text { Plugs (Ref. CDR) }\end{array}$ \\
\hline CHEVRE & U10ay & LLNL & 2 Binders & $\begin{array}{l}\text { CD of Compressed } \\
\text { Raw \& Processed } \\
\text { Data }\end{array}$ & 1 Folder & $\begin{array}{l}1 \text { Ground Motion } \\
\text { Roll (Blue) }\end{array}$ & None & None & None & \\
\hline CHIBERTA & U2ek & LLNL & 1 Binder & None & None & None & Earth Strain Cals. & None & None & \\
\hline CHINCHILLA I & U3ag & $\begin{array}{l}\text { LANL, Pre- } \\
\text { BANEBERRY }\end{array}$ & None & None & None & None & None & $\begin{array}{l}\text { Velocity from Nuclear } \\
\text { Explosions (U)", V. E. } \\
\text { Wheeler, UOPBA 73-44, } \\
3 / 16 / 73 \text {, }\end{array}$ & None & $\begin{array}{l}\text { Surface, Hor. } \\
\text { dist. (NI) (Ref. } \\
\text { UOPBA 73-44) }\end{array}$ \\
\hline CHINCHILLA ॥ & U3as & $\begin{array}{l}\text { LANL, Pre- } \\
\text { BANEBERRY }\end{array}$ & None & None & None & None & None & $\begin{array}{l}\text { Velocity from Nuclear } \\
\text { Explosions (U)", V. E. } \\
\text { Wheeler, UOPBA 73-44, } \\
3 / 16 / 73 \text {, }\end{array}$ & None & $\begin{array}{l}\text { Surface, Hor. } \\
\text { dist. (NI) (Ref. } \\
\text { UOPBA 73-44) }\end{array}$ \\
\hline CLARKSMOBILE & U2as & LLNL & None & $\begin{array}{l}\text { CD of Compressed } \\
\text { Raw \& Processed } \\
\text { Data }\end{array}$ & None & None & None & 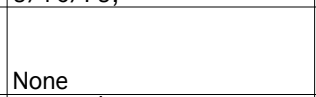 & None & \\
\hline CLEARWATER & U12q & $\begin{array}{l}\text { LLNL, Pre- } \\
\text { BANEBERRY }\end{array}$ & None & None & None & None & None & $\begin{array}{l}\text { Velocity from Nuclear } \\
\text { Explosions (U)", V. E. } \\
\text { Wheeler, UOPBA 73-44, } \\
\text { 3/16/73, . CFRD report } \\
\text { "Summary of Free Field } \\
\text { Ground Motion } \\
\text { Measurements (U)", V. E. } \\
\text { Wheeler/ R. G. Preston, } \\
\text { UOPBA 74-126, 8/21/74, }\end{array}$ & SRI report VUF-2101 & $\begin{array}{l}\text { Surface, Hor. } \\
\text { dist. (NI) (Ref. } \\
\text { UOPBA 73-44); } \\
\text { Subsurface, } 5 \\
\text { vertical GM } \\
\text { gages (Ref. } \\
\text { UOPBA 74-126) }\end{array}$ \\
\hline COFFER & U2de & $\begin{array}{l}\text { LLNL, Pre- } \\
\text { BANEBERRY }\end{array}$ & 1 Binder & None & None & None & $\begin{array}{l}1 \text { Wide } \\
\text { Geophone Roll } \\
\text { (Yellow) }\end{array}$ & None & None & \\
\hline COLBY & U20aa & LLNL & None & None & None & None & Earth Strain Cals. & None & None & \\
\hline
\end{tabular}


Ground Motion Data: Appendix 3B (John Rambo)

\begin{tabular}{|c|c|c|c|c|c|c|c|c|c|c|}
\hline This $\mathrm{C}$ & des in th & DNT Containmer & $\begin{array}{c}\text { DATA } \\
\text { Early LLNL } \\
\text { processed data } \\
\text { and reports }\end{array}$ & $\begin{array}{c}\text { DATA } \\
- \text { Later EG\&G } \\
\begin{array}{c}\text { processed data and } \\
\text { reports }\end{array}\end{array}$ & \begin{tabular}{|c} 
DATA \\
Later data \\
processed at LLNL \\
by EG\&G
\end{tabular} & \begin{tabular}{|c}
483, burkhard1 @llt \\
DATA \\
Data Plots, \\
Surface, \\
Subsurface \\
Ground Motion, \\
Pressure/ \\
Radiation \\
LOS/Displ./ Misc. \\
Similar Items are \\
included in this \\
column.
\end{tabular} & $\begin{array}{c}\text { DATA } \\
\text { Ground Motion at } \\
\text { Distance From } \\
\text { SGZ. Geophone } \\
\text { plots (yellow). }\end{array}$ & Program Leader Gayle Pan & $\begin{array}{c}\text { SUMMARY AND FINAL } \\
\text { REPORTS } \\
\text { CONF=Classified CFRD } \\
\text { CDR=Containment Data } \\
\text { Report }\end{array}$ & $\begin{array}{l}\text { ski@llnl.gov). } \\
\text { GAGE } \\
\text { LOCATIONS FOR } \\
\text { FREE SURFACE } \\
\text { AND FREE FIELD } \\
\text { DATA } \\
\text { RR=Round Robin } \\
\text { Surface gages } \\
\text { RTP=Recording } \\
\text { Trailer Park } \\
\text { ONI=Orientaion } \\
\text { to WP Not } \\
\text { Investigated }\end{array}$ \\
\hline COLWICK & U20ac & LLNL & None & $\begin{array}{l}\text { CD of Compressed } \\
\text { Raw \& Processed } \\
\text { Data }\end{array}$ & 1 Folder & None & None & None & None & \\
\hline COMMODORE & U2am & $\begin{array}{l}\text { LLNL, Pre- } \\
\text { BANEBERRY, } 3 \\
\text { free field gage } \\
\text { gages below the } \\
\text { water table, } 1 \\
\text { free field gage in } \\
\text { carbonate rock }\end{array}$ & 2 Binders & None & None & None & Pathfinder I & $\begin{array}{l}\text { Binders G, R. CFRD report } \\
\text { "Ground Shock Predictions } \\
\text { for Underground Nuclear } \\
\text { Explosions in Rainier Mesa } \\
\text { (U)", L. F. Ingram, J. L. } \\
\text { Drake, DNA-TR-88-14, } \\
10 / 23 / 87 \text {. Unclassified } \\
\text { report "Free-Field Ground } \\
\text { Motion Induced by } \\
\text { Underground Explosions", } \\
\text { W. R. Perret, and R. C. } \\
\text { Bass, SAND74-0252, } \\
\text { Sandia Laboratories, } \\
11 / 72 \text {. CFRD report "Peak } \\
\text { Surface Velocity from } \\
\text { Nuclear Explosions (U)", V. } \\
\text { E. Wheeler, UOPBA 73-44, } \\
\text { 3/16/73, . CFRD report } \\
\text { "Summary of Free Field } \\
\text { Ground Motion } \\
\text { Measurements (U)", V. E. } \\
\text { Wheeler/ R. G. Preston, } \\
\text { UOPBA 74-126, 8/21/74, }\end{array}$ & (1) & $\begin{array}{l} \\
\text { Surface, Hor. } \\
\text { dist. (NI) (Ref. } \\
\text { UOPBA 73-44); } \\
\text { Subsurface, } 1 \\
\text { shot level GM } \\
\text { gage, } 5 \text { offset } \\
\text { vertical GM } \\
\text { gages, } 7 \text { vertical } \\
\text { GM gages (Ref. } \\
\text { UOPBA 74-126) }\end{array}$ \\
\hline СOMSTOCK & U20ay & LLNL & None & \begin{tabular}{|l} 
CD of Compressed \\
Raw \& Processed \\
Data ; CD of ASCII \\
Processed Data ;1 \\
Binder
\end{tabular} & 1 Folder & None & None & None & MISC-4687 (CDR) & $\begin{array}{l}\text { Dist. 50', 1050', } \\
2100^{\prime} \text { (Ref. } \\
\text { CDR): } \\
\text { Subsurface, No } \\
\text { free field gages, } \\
\text { No GM gages in } \\
\text { Plugs (Ref. CDR) }\end{array}$ \\
\hline
\end{tabular}


Ground Motion Data: Appendix 3B (John Rambo)

\begin{tabular}{|c|c|c|c|c|c|c|c|c|c|c|}
\hline (Iils ua & HOLE & COMMENTS & $\begin{array}{c}\text { DATA } \\
\text { Early LLNL } \\
\text { processed data } \\
\text { and reports } \\
\end{array}$ & $\begin{array}{c}\text { DATA } \\
\begin{array}{c}\text { Later EG\&G } \\
\text { processed data and } \\
\text { reports }\end{array} \\
\end{array}$ & \begin{tabular}{|c|} 
DATA \\
Later data \\
processed at LLNL \\
by EG\&G
\end{tabular} & $\begin{array}{c}\text { DATA } \\
\text { Data Plots, } \\
\text { Surface, } \\
\text { Subsurface } \\
\text { Ground Motion, } \\
\text { Pressure/ } \\
\text { Radiation } \\
\text { LOS/Displ./ Misc. } \\
\text { Similar Items are } \\
\text { included in this } \\
\text { column. }\end{array}$ & $\begin{array}{c}\text { DATA } \\
\text { Ground Motion at } \\
\text { Distance From } \\
\text { SGZ. Geophone } \\
\text { plots (yellow). }\end{array}$ & 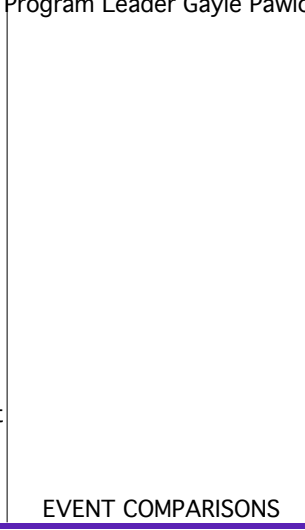 & $\begin{array}{c}\text { SUMMARY AND FINAL } \\
\text { REPORTS } \\
\text { CONF=Classified CFRD } \\
\text { CDR=Containment Data } \\
\text { Report }\end{array}$ & $\begin{array}{c}\text { ski@llnl.gov). } \\
\text { GAGE } \\
\text { LOCATIONS FOR } \\
\text { FREE SURFACE } \\
\text { AND FREE FIELD } \\
\text { DATA } \\
\text { RR=Round Robin } \\
\text { Surface gages } \\
\text { RTP=Recording } \\
\text { Trailer Park } \\
\text { ONI=Orientaion } \\
\text { to WP Not } \\
\text { Investigated }\end{array}$ \\
\hline CONTACT & U20aw & LLNL & None & $\begin{array}{l}\text { CD of Compressed } \\
\text { Raw \& Processed } \\
\text { Data ; CD of ASCll } \\
\text { Processed Data ;1 } \\
\text { Binder }\end{array}$ & 1 Folder & None & None & Binder V & MISC-4893 (CDR) & $\begin{array}{l}\text { Dist. 50', 892', } \\
1785^{\prime} \text { (Ref. } \\
\text { CDR): } \\
\text { Subsurface, No } \\
\text { free field gages, } \\
\text { No GM gages in } \\
\text { Plugs (Ref. CDR) }\end{array}$ \\
\hline & U10k & $\begin{array}{l}\text { LLNL, Pre- } \\
\text { BANEBERRY }\end{array}$ & None & None & 1 Folder & None & None & None & None & \\
\hline $\begin{array}{l}\text { CORNICE GREEN } \\
\text { CORNICE YELLOW }\end{array}$ & \begin{tabular}{|l} 
U10ap 3 \\
U10ap 1
\end{tabular} & $\begin{array}{l}\text { LLNL, Pre- } \\
\text { BANEBERRY } \\
\end{array}$ & 1 Binder & $\begin{array}{l}\text { CD of Compressed } \\
\text { Raw \& Processed } \\
\text { Data }\end{array}$ & None & None & $\begin{array}{l}1 \text { Wide } \\
\text { Geophone Roll } \\
\text { (Yellow) }\end{array}$ & None & None & \\
\hline CORNUCOPIA & U2ga S & LLNL & None & $\begin{array}{l}\text { CD of Compressed } \\
\text { Raw \& Processed } \\
\text { Data; CD of ASCII } \\
\text { Processed Data; } 1 \\
\text { Binder }\end{array}$ & 2 Folders & $\begin{array}{l}2 \text { Ground Motion } \\
\text { Rolls (Blue), } 2 \\
\text { Pres./ Radiation } \\
\text { Printout Rolls } \\
\text { (Red) }\end{array}$ & $\begin{array}{l}1 \text { Geophone Roll } \\
\text { (Yellow) }\end{array}$ & $\begin{array}{l}\text { Binder W, Binder U (Peak } \\
\text { Accelleration of Trailers), } \\
\text { Binder T (CLIPER/EXCOR), } \\
5 \text { Presentation Binders }\end{array}$ & $\begin{array}{l}\text { "CORNUCOPIA Cavity } \\
\text { Pressure Measurement" } \\
\text { UCRL } 96354, \text { UCRL-ID- } \\
120665 \text { (CDR) }\end{array}$ & $\begin{array}{l}\text { Dist. 50', RTP } \\
\text { (Ref. CDR): } \\
\text { Subsurface, No } \\
\text { free field gages, } \\
2 \text { GM gages in } \\
\text { Plugs (Ref. CDR) }\end{array}$ \\
\hline $\cos O$ & U4an & LLNL & None & $\begin{array}{l}\text { CD of Compressed } \\
\text { Raw \& Processed } \\
\text { Data; CD of ASCII } \\
\text { Processed Data; } 1 \\
\text { Binder }\end{array}$ & 2 Folders & None & None & 2 Presentation Binders & UCRL-MI-107445 (CDR) & $\begin{array}{l}\text { Dist. 50', RTP } \\
\text { (Ref. CDR): } \\
\text { Subsurface, No } \\
\text { free field gages, } \\
1 \text { GM gage in } \\
\text { Plug (Ref. CDR) }\end{array}$ \\
\hline COTTAGE & U8j & LLNL & None & $\begin{array}{l}\text { CD of Compressed } \\
\text { Raw \& Processed } \\
\text { Data; CD of ASCII } \\
\text { Processed Data } \\
\end{array}$ & None & None & $\begin{array}{l}\text { Pathtinder CD } \\
\text { with interaction } \\
\text { measurment } \\
\text { made at VILLE. }\end{array}$ & 4 Presentation Binders & None & \\
\hline COULOMMIERS & U2ei & LLNL & \begin{tabular}{|l} 
CFRD report \\
"Notes on \\
COULOMMIERS \\
Instrumentation \\
Plan (U)", V. E. \\
Wheeler/ R. G. \\
Preston, UOPBA 76 \\
$154,9 / 20 / 76$. \\
\end{tabular} & $\begin{array}{l}\text { CD of Compressed } \\
\text { Raw \& Processed } \\
\text { Data }\end{array}$ & 1 Folder & None & Pathfinder II or III & None & None & \\
\hline
\end{tabular}


Ground Motion Data: Appendix 3B (John Rambo)

\begin{tabular}{|c|c|c|c|c|c|c|c|c|c|c|}
\hline 更 & HOLE & 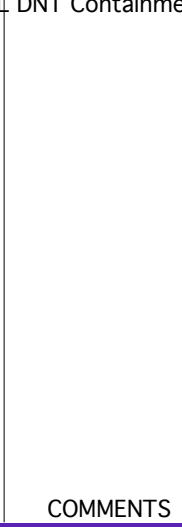 & $\begin{array}{l}\text { DATA } \\
\text { Early LLNL } \\
\text { processed data } \\
\text { and reports }\end{array}$ & $\begin{array}{c}\text { DATA } \\
\text { Later EG\&G } \\
\begin{array}{c}\text { processed data and } \\
\text { reports }\end{array}\end{array}$ & $\begin{array}{c}\text { DATA } \\
- \text { Later data } \\
\text { processed at LLNL } \\
\text { by EG\&G }\end{array}$ & \begin{tabular}{|c|} 
DATA \\
Data Plots, \\
Surface, \\
Subsurface \\
Ground Motion, \\
Pressure/ \\
Radiation \\
LOS/Displ./ Misc. \\
Similar Items are \\
included in this \\
column.
\end{tabular} & $\begin{array}{c}\text { DATA } \\
\text { Ground Motion at } \\
\text { Distance From } \\
\text { SGZ. Geophone } \\
\text { plots (yellow). }\end{array}$ & 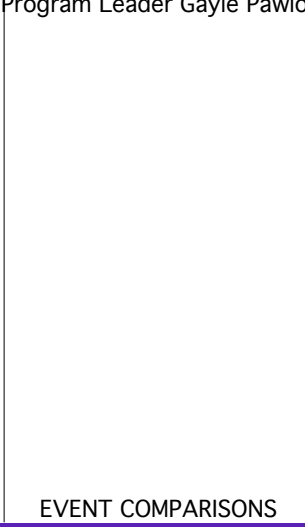 & $\begin{array}{c}\text { SUMMARY AND FINAL } \\
\text { REPORTS } \\
\overline{\text { CONF=Classified CFRD }} \\
\begin{array}{c}\text { CDR=Containment Data } \\
\text { Report }\end{array}\end{array}$ & $\begin{array}{c}\text { GAGE } \\
\text { LOCATIONS FOR } \\
\text { FREE SURFACE } \\
\text { AND FREE FIELD } \\
\text { DATA } \\
\text { RR=Round Robin } \\
\text { Surface gages } \\
\text { RTP=Recording } \\
\text { Trailer Park } \\
\text { ONI=Orientaion } \\
\text { to WP Not } \\
\text { Investigated }\end{array}$ \\
\hline COVE & U3ki & LANL & None & None & None & None & \begin{tabular}{|l|} 
Earth Strain \\
Cals., PDS Cals.
\end{tabular} & None & None & \\
\hline COWLES & U3hx & LANL & None & None & None & None & $\begin{array}{l}\text { "Round Robin } \\
\text { Program } \\
\text { COWLES Event } \\
\text { (U)", W. R. } \\
\text { Perret, Sandia } \\
\text { UOPBA 72- } \\
\text { 924,2/28/72 } \\
\text { (V). }\end{array}$ & None & None & $\begin{array}{l}\text { Surface,Horiz. } \\
51 \text { ',495', } 510^{\prime} \\
\text { and } 485^{\prime}\end{array}$ \\
\hline CREMINO & U8e & LLNL & None & $\begin{array}{l}\text { CD of Compressed } \\
\text { Raw \& Processed } \\
\text { Data; CD of ASCII } \\
\text { Processed Data; } 2 \\
\text { Binders on Ground } \\
\text { Motion, } 1 \text { Binder on } \\
\text { Collapse, } \\
\end{array}$ & 1 Folder & 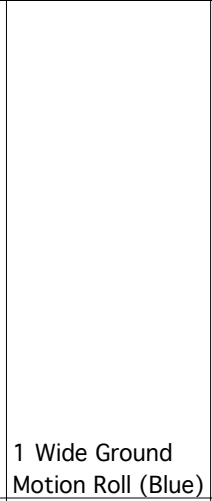 & Earth Strain Cals. & $\begin{array}{l}1 \text { Presentation Binder } \\
\text { CFRD report "Peak Surface } \\
\text { Velocity from Nuclear } \\
\text { Explosions }(U) ", \text { V. E. } \\
\text { Wheeler, UOPBA } 73-44 \text {, } \\
3 / 16 / 73 \text {, }\end{array}$ & None & $\begin{array}{l}\text { Surface, Horlz., } \\
\text { 51', 495', 510', } \\
495 ' \text { (Ref. RR); } \\
\text { Surface, Horiz. } \\
\text { Dist. 50' (Ref. } \\
\text { CDR): } \\
\text { Subsurface, Free } \\
\text { field gages, } 9 \\
\text { vertical offset } \\
\text { GM gages, } 3 \\
\text { vertical offset } \\
\text { Sandia soil } \\
\text { stress gages, } 3 \\
\text { GM gages in } \\
\text { Plugs (Ref. CDR) } \\
\text { See report. }\end{array}$ \\
\hline CRESTLAKE & U2dw & LLNL & 2 Binders & $\begin{array}{l}\text { CD of Compressed } \\
\text { Raw \& Processed } \\
\text { Data } \\
\end{array}$ & 1 Folder & $\begin{array}{l}9 \text { Ground Motion } \\
\text { Rolls in Box. }\end{array}$ & None & Binder B & $\begin{array}{l}\text { CRD report "Response of } \\
\text { the PINEX Pipe in } \\
\text { CRESTLAKE (U)", V. E. } \\
\text { Wheeler/R. G. Preston, } \\
\text { UOPBA } 75-26,2 / 6 / 75, \text {. }\end{array}$ & $\begin{array}{l}\text { May have a } \\
\text { surface GM } \\
\text { gage. }\end{array}$ \\
\hline
\end{tabular}


Ground Motion Data: Appendix 3B (John Rambo)

\begin{tabular}{|c|c|c|c|c|c|c|c|c|c|c|}
\hline This & sides in the & DNT Containm & Program files. Pro & \begin{tabular}{|c|} 
DATA \\
$\begin{array}{c}\text { Later EG\&G } \\
\text { processed data and } \\
\text { reports }\end{array}$
\end{tabular} & $\begin{array}{c}\text { DATA } \\
\text { Later data } \\
\text { processed at LLNL } \\
\text { by EG\&G }\end{array}$ & \begin{tabular}{|c} 
DATA \\
--_ata Plots, \\
Surface, \\
Subsurface \\
Ground Motion, \\
Pressure/ \\
Radiation \\
LOS/Displ./ Misc. \\
Similar Items are \\
included in this \\
column.
\end{tabular} & \begin{tabular}{|c|} 
DATA \\
Ground Motion at \\
Distance From \\
SGZ. Geophone \\
plots (yellow).
\end{tabular} & Program Leader Gayle Pawlo & $\begin{array}{c}\text { SUMMARY AND FINAL } \\
\text { REPORTS } \\
\text { CONF=Classified CFRD } \\
\text { CDR=Containment Data } \\
\text { Report }\end{array}$ & $\begin{array}{c}\text { oski@llnl.gov). } \\
\text { GAGE } \\
\text { LOCATIONS FOR } \\
\text { FREE SURFACE } \\
\text { AND FREE FIELD } \\
\text { DATA } \\
\text { RR=Round Robin } \\
\text { Surface gages } \\
\text { RTP=Recording } \\
\text { Trailer Park } \\
\text { ONI=Orientaion } \\
\text { to WP Not } \\
\text { Investigated }\end{array}$ \\
\hline CREW & U2db & $\begin{array}{l}\text { LLNL, Pre- } \\
\text { BANEBERRY }\end{array}$ & 11 Binders & (1) & $\begin{array}{l}1 \text { Folder, and } \\
\text { CFRD report } \\
\text { "Comparison of a } \\
\text { Two-Layered Model } \\
\text { Calculation of } \\
\text { AGILE with } \\
\text { Obsevations; } \\
\text { Projection of the } \\
\text { Model to CREW } \\
\text { (U)",R. G. Preston } \\
\text { and V. E. Wheeler, } \\
\text { UOPKG 68-3, } \\
\text { 2/9/68, . CFRD } \\
\text { report "Corrections } \\
\text { to LRL Memos, Ser } \\
\text { UOPKG 68-3 and } \\
\text { UOPKG 68-3 } \\
\text { Addendum (U)", V. } \\
\text { E. Wheeler/R. G. } \\
\text { Preston, UOPKG 68- } \\
\text { 9,3/21/68, . }\end{array}$ & None & None & $\begin{array}{l}\text { CFRD report "Summary of } \\
\text { Free Field Ground Motion } \\
\text { Measurments(U)", V. E. } \\
\text { Wheeler/ R. G. Preston, } \\
\text { UOPBA 74-126, 8/21/74, }\end{array}$ & 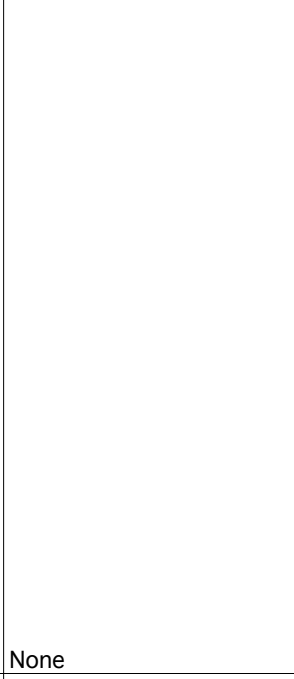 & $\begin{array}{l} \\
\\
\text { Subsurface } 18 \\
\text { offset vertical } \\
\text { GM gages (Ref. } \\
\text { UOPBA 74-126) }\end{array}$ \\
\hline CREWLINE & U7ap & LANL & None & None & None & None & $\begin{array}{l}\text { Pathfinder CD of } \\
\text { Compressed Raw } \\
\& \text { Processed } \\
\text { Data (V) }\end{array}$ & None & None & \\
\hline CROWDIE & U2fe & LLNL & None & $\begin{array}{l}\text { CD of Compressed } \\
\text { Raw \& Processed } \\
\text { Data ; CD of ASCII } \\
\text { Processed Data ; } 1 \\
\text { Binder }\end{array}$ & 1 Folder & $\begin{array}{l}2 \text { Ground Motion } \\
\text { Rolls (Blue), } 1 \\
\text { Roll of Pres./ } \\
\text { Radiation Traces } \\
\text { (Red) }\end{array}$ & None & $\begin{array}{l}\text { Binder Y, Binder T } \\
\text { (CLIPER/EXCOR) }\end{array}$ & $\begin{array}{l}\text { Draft Report "Preliminary } \\
\text { Data Report: CROWDIE } \\
\text { Motion, Pressure and } \\
\text { Radiation" ; UCRL-ID- } \\
122262 \text { (CDR) }\end{array}$ & $\begin{array}{l}\text { Dist. 50', RTP } \\
\text { (Ref. CDR): } \\
\text { Subsurface, No } \\
\text { free field gages, } \\
2 \text { GM gages in } \\
\text { Plugs (Ref. CDR) }\end{array}$ \\
\hline CRUET & $\mathrm{U} 2 \mathrm{cn}$ & \begin{tabular}{|l|} 
LLNL, Pre- \\
BANEBERRY
\end{tabular} & None & None & None & None & $\begin{array}{l}3 \text { Geophone Rolls } \\
\text { (Yellow) }\end{array}$ & None & None & \\
\hline CYATHUS & U8b & $\begin{array}{l}\text { LLNL, Pre- } \\
\text { BANEBERRY }\end{array}$ & None & $\begin{array}{l}\text { CD of Compressed } \\
\text { Raw \& Processed } \\
\text { Data }\end{array}$ & None & None & None & None & None & \\
\hline
\end{tabular}


Ground Motion Data: Appendix 3B (John Rambo)

\begin{tabular}{|c|c|c|c|c|c|c|c|c|c|c|}
\hline 更 & HOLE & 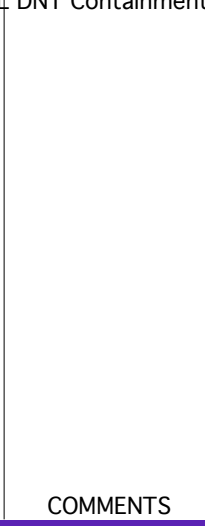 & $\begin{array}{c}\text { DATA } \\
\text { Early LLNL } \\
\text { processed data } \\
\text { and reports }\end{array}$ & $\begin{array}{c}\text { DATA } \\
\begin{array}{c}\text { Later EG\&G } \\
\text { processed data and } \\
\text { reports }\end{array}\end{array}$ & $\begin{array}{c}\text { DATA } \\
- \text { Later data } \\
\begin{array}{c}\text { processed at LLNL } \\
\text { by EG\&G }\end{array}\end{array}$ & \begin{tabular}{|c} 
DATA \\
- Data Plots, \\
Surface, \\
Subsurface \\
Ground Motion, \\
Pressure/ \\
Radiation \\
LOS/Displ./ Misc. \\
Similar Items are \\
included in this \\
column.
\end{tabular} & $\begin{array}{c}\text { DATA } \\
\text { Ground Motion at } \\
\text { Distance From } \\
\text { SGZ. Geophone } \\
\text { plots (yellow). }\end{array}$ & EVENT COMPARISONS & $\begin{array}{c}\text { SUMMARY AND FINAL } \\
\text { REPORTS } \\
\text { CONF=Classified CFRD } \\
\begin{array}{c}\text { CDR=Containment Data } \\
\text { Report }\end{array}\end{array}$ & $\begin{array}{l}\text { GAGE } \\
\text { LOCATIONS FOR } \\
\text { FREE SURFACE } \\
\text { AND FREE FIELD } \\
\text { DATA } \\
\text { RR=Round Robin } \\
\text { Surface gages } \\
\text { RTP=Recording } \\
\text { Trailer Park } \\
\text { ONI=Orientaion } \\
\text { to WP Not } \\
\text { Investigated }\end{array}$ \\
\hline CYPRESS & U12g.09 & $\begin{array}{l}\text { LLNL/SANDIA/D } \\
\text { OD, Pre- } \\
\text { BANEBERRY }\end{array}$ & None & None & 1 Folder & None & $\mid$ & $\begin{array}{l}\text { LFKU report "reak surtace } \\
\text { Velocity from Nuclear } \\
\text { Explosions (U)", V. E. } \\
\text { Wheeler, UOPBA 73-44, } \\
3 / 16 / 73, \text {. CFRD report } \\
\text { "Summary of Free Field } \\
\text { Ground Motion } \\
\text { Measurements (U)", V. E. } \\
\text { Wheeler/ R. G. Preston, } \\
\text { UOPBA 74-126, 8/21/74, } \\
\text {. CFRD report "Ground } \\
\text { Shock Predictions for } \\
\text { Underground Nuclear } \\
\text { Explosions in Rainier Mesa } \\
\text { (U)", L. F. Ingram, J. L. } \\
\text { Drake, DNA-TR-88-14, } \\
\text { 10/23/87, . }\end{array}$ & Sandia, not reported & $\begin{array}{l}\text { Surface, Hor. } \\
\text { dist. (NI) (Ref. } \\
\text { UOPBA 73-44); } \\
\text { Subsurface, } 9 \\
\text { vertical GM } \\
\text { gages (Ref. } \\
\text { UOPBA 74-126), } \\
7 \text { GM gages } \\
\text { (Ref. DNA-TR-88 } \\
\text { 14) }\end{array}$ \\
\hline DAMAN I & U3be & \begin{tabular}{|l} 
LANL, Pre- \\
BANEBERRY
\end{tabular} & None & None & None & None & None & $\begin{array}{l}\text { CrRU report "reak surtace } \\
\text { Velocity from Nuclear } \\
\text { Explosions (U)", V. E. } \\
\text { Wheeler, UOPBA 73-44, } \\
3 / 16 / 73, \text {. }\end{array}$ & 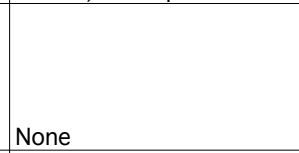 & $\begin{array}{l}\text { Surface, Hor. } \\
\text { dist. (NI) (Ref. } \\
\text { UOPBA 73-44) }\end{array}$ \\
\hline DANABLU & U2eu & LLNL & None & None & 1 Folder & None & None & None & None & \\
\hline DARWIN & U20aq & AWRE/LLNL & None & $\begin{array}{l}\text { Raw \& Processed } \\
\text { Data; CD of ASCII } \\
\text { Processed Data } \\
\end{array}$ & None & None & None & 1 Presentation Binder & None & \\
\hline DAUPHIN & U9cq & LLNL & None & $\begin{array}{l}\text { CD of Compressed } \\
\text { Raw \& Processed } \\
\text { Data; CD of ASCII } \\
\text { Processed Data ; } 2 \\
\text { Binders (1 white, } 1 \\
\text { blue), }\end{array}$ & 1 Folder & $\begin{array}{l}1 \text { Ground Motion } \\
\text { Roll (Blue) }\end{array}$ & None & $\begin{array}{l}\text { Binder U (Peak } \\
\text { Accelleration of Trailers) }\end{array}$ & $\begin{array}{l}\text { "Motion Measured in the } \\
\text { Medium Around the } \\
\text { DAUPHINE Event" UOPKL- } \\
82-50 \text {; UCRL-ID-127714 } \\
\text { (CDR) }\end{array}$ & $\begin{array}{l}\text { Dist. 50', RTP } \\
\text { (Ref. CDR): } \\
\text { Subsurface, No } \\
\text { free field gages, } \\
4 \text { GM gages in } \\
\text { Plugs (Ref. CDR) }\end{array}$ \\
\hline DECK & U3kd & LANL & None & None & None & None & Earth Strain & None & None & \\
\hline
\end{tabular}


Ground Motion Data: Appendix 3B (John Rambo)

\begin{tabular}{|c|c|c|c|c|c|c|c|c|c|c|}
\hline This d & HOLE & 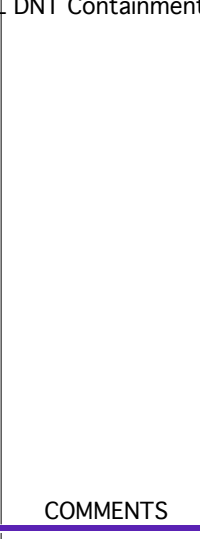 & $\begin{array}{c}\text { DATA } \\
\text { Early LLNL } \\
\text { processed data } \\
\text { and reports } \\
\end{array}$ & $\begin{array}{c}\text { DATA } \\
\text { Later EG\&G } \\
\begin{array}{c}\text { processed data and } \\
\text { reports }\end{array}\end{array}$ & \begin{tabular}{|c|} 
DATA \\
Later data \\
$\begin{array}{c}\text { processed at LLNL } \\
\text { by EG\&G }\end{array}$
\end{tabular} & \begin{tabular}{|c|} 
DATA \\
Data Plots, \\
Surface, \\
Subsurface \\
Ground Motion, \\
Pressure/ \\
Radiation \\
LOS/Displ./ Misc. \\
Similar Items are \\
included in this \\
column. \\
\end{tabular} & \begin{tabular}{|c|} 
DATA \\
Ground Motion at \\
Distance From \\
SGZ. Geophone \\
plots (yellow).
\end{tabular} & EVENT COMPARISONS & $\begin{array}{c}\text { SUMMARY AND FINAL } \\
\text { REPORTS } \\
\text { CONF=Classified CFRD } \\
\text { CDR=Containment Data } \\
\text { Report }\end{array}$ & $\begin{array}{l}\text { GAGE } \\
\text { LOCATIONS FOR } \\
\text { FREE SURFACE } \\
\text { AND FREE FIELD } \\
\text { DATA } \\
\text { RR=Round Robin } \\
\text { Surface gages } \\
\text { RTP=Recording } \\
\text { Trailer Park } \\
\text { ONI=Orientaion } \\
\text { to WP Not } \\
\text { Investigated }\end{array}$ \\
\hline DELAMAR & U20at & LLNL & None & $\begin{array}{l}\text { CD of Compressed } \\
\text { Raw \& Processed } \\
\text { Data; CD of ASCII } \\
\text { Processed Data } \\
\end{array}$ & 1 Folder & None & \begin{tabular}{|l|} 
I UELAIVIAK \\
Ground Motion \\
Listing at the \\
HARDIN Site. \\
Located in \\
HARDIN Box \\
\end{tabular} & $\begin{array}{l}\text { Binder T (CLIPER/EXCOR), } \\
2 \text { Presentation Binders }\end{array}$ & $\begin{array}{l}\text { "DELAMAR-induced } \\
\text { Ground Motion at the } \\
\text { HARDIN Site" UCID-21151 } \\
\text { Rev. } 1 \text { (Motion at } \\
\text { HARDIN) }\end{array}$ & \\
\hline DELPHINIUM & U2dp & LLNL & 3 Binders & $\begin{array}{l}\text { CD of Compressed } \\
\text { Raw \& Processed } \\
\text { Data }\end{array}$ & 1 Folder & None & None & $\begin{array}{l}\text { Binder B. CFRD report } \\
\text { "Peak Surface Velocity } \\
\text { from Nuclear Explosions } \\
\text { (U)", V. E. Wheeler, UOPBA } \\
73-44,3 / 16 / 73 \text {, }\end{array}$ & $\begin{array}{l}\text { CRD report "Containment } \\
\text { Diagnostics for } \\
\text { DELPHINIUM (U)", C. W. } \\
\text { Olsen, UOPBA 72-125, } \\
\text { 10/24/72, (C) }\end{array}$ & $\begin{array}{l}\text { Surface, Hor. } \\
\text { dist. (NI) (Ref. } \\
\text { UOPBA 73-44) }\end{array}$ \\
\hline DERRINGER & U5i & $\begin{array}{l}\text { LANL/Sandia/DO } \\
\text { D, Pre- } \\
\text { BANEBERRY }\end{array}$ & None & None & None & None & None & $\begin{array}{l}\text { Velocity from Nuclear } \\
\text { Explosions (U)", V. E. } \\
\text { Wheeler, UOPBA 73-44, } \\
3 / 16 / 73 \text {, }\end{array}$ & 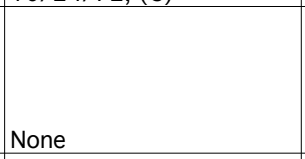 & $\begin{array}{l}\text { Surface, Hor. } \\
\text { dist. (NI) (Ref. } \\
\text { UOPBA 73-44) }\end{array}$ \\
\hline DIABLO HAWK & U12n.10a & $\begin{array}{l}\text { LLNL/DOD } \\
\end{array}$ & \begin{tabular}{|l|} 
None \\
None
\end{tabular} & $\begin{array}{l}\text { None } \\
\text { None }\end{array}$ & $\begin{array}{l}\text { None } \\
1 \text { Folder }\end{array}$ & \begin{tabular}{|l|} 
None \\
None
\end{tabular} & \begin{tabular}{|l|} 
\\
Earth Strain Cals. \\
None
\end{tabular} & $\begin{array}{l}\text { CFRD report "Ground } \\
\text { Shock Predictions for } \\
\text { Underground Nuclear } \\
\text { Explosions in Rainier Mesa } \\
\text { (U)", L. F. Ingram, J. L. } \\
\text { Drake, DNA-TR-88-14, } \\
10 / 23 / 87, \text {. } \\
\end{array}$ & $\begin{array}{l}\text { None } \\
\text { None }\end{array}$ & $\begin{array}{l}\text { GM gages, } 4 \\
\text { Sandia stress } \\
\text { gages, } 16 \text { PI GM } \\
\text { gages, } 26 \text { PI } \\
\text { stress gages, } 12 \\
\text { WES GM } \\
\text { gages, } 11 \text { WES } \\
\text { stress gages } \\
\text { (Ref. DNA-TR-88- } \\
\text { 14) }\end{array}$ \\
\hline DIAGONAL LINE & U11g & LLNL/DOD & None & None & 1 Folder & None & None & None & None & \\
\hline
\end{tabular}


Ground Motion Data: Appendix 3B (John Rambo)

\begin{tabular}{|c|c|c|c|c|c|c|c|c|c|c|}
\hline This data & des in $t$ & NT Containme & $\begin{array}{c}\text { DATA } \\
\text { Early LLNL } \\
\text { processed data } \\
\text { and reports }\end{array}$ & $\begin{array}{c}\text { DATA } \\
\text { Later EG\&G } \\
\begin{array}{c}\text { processed data and } \\
\text { reports }\end{array}\end{array}$ & $\begin{array}{c}\text { DATA } \\
\text { Later data } \\
\text { processed at LLNL } \\
\text { by EG\&G }\end{array}$ & $\begin{array}{c}\text { 483, burkhard1@ @ll } \\
\text { DATA } \\
\text { Data Plots, } \\
\text { Surface, } \\
\text { Subsurface } \\
\text { Ground Motion, } \\
\text { Pressure/ } \\
\text { Radiation } \\
\text { LOS/Displ./ Misc. } \\
\text { Similar Items are } \\
\text { included in this } \\
\text { column. }\end{array}$ & $\begin{array}{c}\text { DATA } \\
\text { Ground Motion at } \\
\text { Distance From } \\
\text { SGZ. Geophone } \\
\text { plots (yellow). }\end{array}$ & rogram Leader Gayle Pa & $\begin{array}{c}\text { SUMMARY AND FINAL } \\
\text { REPORTS } \\
\text { CONF=Classified CFRD } \\
\text { CDR=Containment Data } \\
\text { Report }\end{array}$ & $\begin{array}{l}\text { ski@llnl.gov). } \\
\text { GAGE } \\
\text { LOCATIONS FOR } \\
\text { FREE SURFACE } \\
\text { AND FREE FIELD } \\
\text { DATA } \\
\text { RR=Round Robin } \\
\text { Surface gages } \\
\text { RTP=Recording } \\
\text { Trailer Park } \\
\text { ONI=Orientaion } \\
\text { to WP Not } \\
\text { Investigated }\end{array}$ \\
\hline DIAMOND SCULLS & U12t.02 & LLNL/DOD & None & None & 1 Folder & None & None & $\begin{array}{l}\text { LFKD report "reak surrace } \\
\text { Velocity from Nuclear } \\
\text { Explosions (U)", V. E. } \\
\text { Wheeler, UOPBA 73-44, } \\
3 / 16 / 73, \text {. CFRD report } \\
\text { "Summary of Free Field } \\
\text { Ground Motion } \\
\text { Measurements (U)", V. E. } \\
\text { Wheeler/ R. G. Preston, } \\
\text { UOPBA 74-126, 8/21/74, } \\
\text {. CFRD report "Ground } \\
\text { Shock Predictions for } \\
\text { Underground Nuclear } \\
\text { Explosions in Rainier Mesa } \\
\text { (U)", L. F. Ingram, J. L. } \\
\text { Drake, DNA-TR-88-14, } \\
\text { 10/23/87, . }\end{array}$ & \begin{tabular}{|l} 
\\
\\
\\
\\
Sandia report SLA-73- \\
1010, PI report POR \\
6725, Sandia report \\
SAND74-0654 (no wave \\
forms), Sandia report \\
SAND74-0252 (no wave \\
forms).
\end{tabular} & $\begin{array}{l}\text { Surface, Hor. } \\
\text { dist. (NI) (Ref. } \\
\text { UOPBA 73-44); } \\
\text { Subsurface, 5 } \\
\text { GM gages (ONI) } \\
\text { (Ref. UOPBA 74- } \\
\text { 126), } 1 \text { PI GM } \\
\text { gage, } 2 \text { Sandia } \\
\text { stress gages, } 3 \\
\text { Sandia GM } \\
\text { gages, (ONI) } \\
\text { (Ref. DNA-TR- } \\
\text { 88-14) }\end{array}$ \\
\hline DIANA MIST & U12n.06 & $\begin{array}{l}\text { LANL/DOD, Pre- } \\
\text { BANEBERRY }\end{array}$ & None & None & None & None & & $\begin{array}{l}\text { CFRD report "Summary of } \\
\text { Free Field Ground Motion } \\
\text { Measurements (U)", V. E. } \\
\text { Wheeler/ R. G. Preston, } \\
\text { UOPBA 74-126, 8/21/74, } \\
\text {. CFRD report "Ground } \\
\text { Shock Predictions for } \\
\text { Underground Nuclear } \\
\text { Explosions in Rainier Mesa } \\
\text { (U)", L. F. Ingram, J. L. } \\
\text { Drake, DNA-TR-88-14, } \\
\text { 10/23/87, . }\end{array}$ & $\begin{array}{l}\text { SRI/PI POR-6389 or WT- } \\
6389\end{array}$ & $\begin{array}{l}\text { Subsurface, } 5 \\
\text { GM gages (ONI) } \\
\text { (Ref. UOPBA 74- } \\
\text { 126), } 2 \text { PI GM } \\
\text { gages (Ref. DNA- } \\
\text { TR-88-14) }\end{array}$ \\
\hline DIANTHUS & U10at & LLNL & None & $\begin{array}{l}\text { CD of Compressed } \\
\text { Raw \& Processed } \\
\text { Data }\end{array}$ & 1 Folder & None & $\begin{array}{l}\text { "Round Robin } \\
\text { Program } \\
\text { DIANTHUS Event } \\
\text { (U)", W. R. } \\
\text { Perret, Sandia } \\
\text { UOPBA 72-32, } \\
\text { 3/17/72 (V). } \\
\end{array}$ & $\begin{array}{l}\text { CFRD report "Peak Surface } \\
\text { Velocity from Nuclear } \\
\text { Explosions }(U) ", \text { V. E. } \\
\text { Wheeler, UOPBA } 73-44, \\
3 / 16 / 73, \text {. } \\
\end{array}$ & None & $\begin{array}{l}\text { Surface (Ref. } \\
\text { RR) Horiz., 50', } \\
499^{\prime}, 500^{\prime} . \\
\end{array}$ \\
\hline
\end{tabular}


Ground Motion Data: Appendix 3B (John Rambo)

\begin{tabular}{|c|c|c|c|c|c|c|c|c|c|c|}
\hline 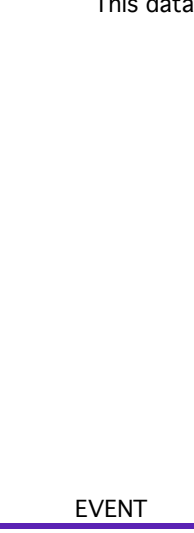 & HOLE & COMMENTS & $\begin{array}{c}\text { DATA } \\
\text { Early LLNL } \\
\text { processed data } \\
\text { and reports }\end{array}$ & $\begin{array}{c}\text { DATA } \\
\begin{array}{c}\text { Later EG\&G } \\
\text { processed data and } \\
\text { reports }\end{array}\end{array}$ & $\begin{array}{c}\text { DATA } \\
-1 \text { Later data } \\
\begin{array}{c}\text { processed at LLNL } \\
\text { by EG\&G }\end{array} \\
\end{array}$ & \begin{tabular}{|c} 
DATA \\
- 2 ata Plots, \\
Surface, \\
Subsurface \\
Ground Motion, \\
Pressure/ \\
Radiation \\
LOS/Displ./ Misc. \\
Similar Items are \\
included in this \\
column. \\
\end{tabular} & \begin{tabular}{|c|} 
DATA \\
Ground Motion at \\
Distance From \\
SGZ. Geophone \\
plots (yellow).
\end{tabular} & EVENT COMPARISONS & $\begin{array}{c}\text { SUMMARY AND FINAL } \\
\text { REPORTS } \\
\text { CONF=Classified CFRD } \\
\begin{array}{c}\text { CDR=Containment Data } \\
\text { Report }\end{array} \\
\end{array}$ & $\begin{array}{c}\text { GSkI@ilni.gov). } \\
\text { GAGE } \\
\text { LOCATIONS FOR } \\
\text { FREE SURFACE } \\
\text { AND FREE FIELD } \\
\text { DATA } \\
\text { RR=Round Robin } \\
\text { Surface gages } \\
\text { RTP=Recording } \\
\text { Trailer Park } \\
\text { ONI=Orientaion } \\
\text { to WP Not } \\
\text { Investigated }\end{array}$ \\
\hline DIDO QUEEN & U12e. 14 & LLNL/DOD & None & None & None & None & None & $\begin{array}{l}\text { CFRD report "Ground } \\
\text { Shock Predictions for } \\
\text { Underground Nuclear } \\
\text { Explosions in Rainier Mesa } \\
\text { (U)", L. F. Ingram, J. L. } \\
\text { Drake, DNA-TR-88-14, } \\
\text { 10/23/87, . }\end{array}$ & $\begin{array}{l}\text { SCUBED report POR 6785, } \\
\text { Sandia unreported (Priv. } \\
\text { Com. Bass) }\end{array}$ & \begin{tabular}{|l} 
SCUBED stress \\
gages, 3 \\
SCUBED GM \\
gages, 3 Sandia \\
stress gages, 1 \\
Sandia GM gage \\
(Ref. DNA-TR-88 \\
14)
\end{tabular} \\
\hline DIESEL TRAIN & U12e. 11 & $\begin{array}{l}\text { LANL/DOD, Pre- } \\
\text { BANEBERRY }\end{array}$ & None & None & None & None & None & $\begin{array}{l}\text { CFRD report "Summary of } \\
\text { Free Field Ground Motion } \\
\text { Measurements (U)", V. E. } \\
\text { Wheeler/ R. G. Preston, } \\
\text { UOPBA 74-126, 8/21/74, } \\
\text {. CFRD report "Ground } \\
\text { Shock Predictions for } \\
\text { Underground Nuclear } \\
\text { Explosions in Rainier Mesa } \\
\text { (U)", L. F. Ingram, J. L. } \\
\text { Drake, DNA-TR-88-14, } \\
\text { 10/23/87, . }\end{array}$ & $\begin{array}{l}\text { Sandia/DOD, unreported, } \\
\text { Sandia report SAND 74- } \\
\text { 0252 (no wavveforms), PI } \\
\text { report POR } 6364\end{array}$ & $\begin{array}{l}\text { Subsurface, } 8 \\
\text { shot level GM } \\
\text { gages (Ref. } \\
\text { UOPBA 74-126), } \\
7 \text { Sandia GM } \\
\text { gages, } 2 \text { PI GM } \\
\text { gages (Ref. DNA- } \\
\text { TR-88-14) }\end{array}$ \\
\hline DILUTED WATER & U5b & LLNL/DOD & None & None & None & None & None & $\begin{array}{l}\text { CFRD report "Peak Surtace } \\
\text { Velocity from Nuclear } \\
\text { Explosions (U)", V. E. } \\
\text { Wheeler, UOPBA 73-44, } \\
3 / 16 / 73 \text {, }\end{array}$ & None & $\begin{array}{l}\text { Surface, Hor. } \\
\text { dist. (NI) (Ref. } \\
\text { UOPBA 73-44) }\end{array}$ \\
\hline DINING CAR & U12e.18 & LLNL/DOD & None & None & None & None & PDS Cals. & $\begin{array}{l}\text { Shock Predictions for } \\
\text { Underground Nuclear } \\
\text { Explosions in Rainier Mesa } \\
\text { (U)", L. F. Ingram, J. L. } \\
\text { Drake, DNA-TR-88-14, } \\
\text { 10/23/87, . }\end{array}$ & $\begin{array}{l}\text { SCUBED report POR SSS-R- } \\
75-2638\end{array}$ & $\begin{array}{l}\text { Subsurface, } 1 \\
\text { SCUBED stress } \\
\text { gage, } 2 \text { SCUBED } \\
\text { GM gages, (Ref. } \\
\text { DNA-TR-88-14) } \\
\text { (ONI) }\end{array}$ \\
\hline
\end{tabular}


Ground Motion Data: Appendix 3B (John Rambo)

\begin{tabular}{|c|c|c|c|c|c|c|c|c|c|c|}
\hline This data & ent & DI Containment & $\begin{array}{c}\text { DATA } \\
\text { Early LLNL } \\
\text { processed data } \\
\text { and reports } \\
\end{array}$ & $\begin{array}{c}\text { DATA } \\
\text { Later EG\&G } \\
\begin{array}{c}\text { processed data and } \\
\text { reports }\end{array}\end{array}$ & $\begin{array}{c}\text { DATA } \\
\text { Later data } \\
\begin{array}{c}\text { processed at LLNL } \\
\text { by EG\&G }\end{array}\end{array}$ & \begin{tabular}{|c} 
DATA \\
Data Plots, \\
Surface, \\
Subsurface \\
Ground Motion, \\
Pressure/ \\
Radiation \\
LOS/Displ./ Misc. \\
Similar Items are \\
included in this \\
column.
\end{tabular} & \begin{tabular}{|c|} 
DATA \\
Ground Motion at \\
Distance From \\
SGz. Geophone \\
plots (yellow).
\end{tabular} & EVENT COMPARISONS & $\begin{array}{c}\text { SUMMARY AND FINAL } \\
\text { REPORTS } \\
\text { CONF=Classified CFRD } \\
\text { CDR=Containment Data } \\
\text { Report }\end{array}$ & $\begin{array}{c}\text { Gski@inl.gov). } \\
\text { GAGE } \\
\text { LOCATIONS FOR } \\
\text { FREE SURFACE } \\
\text { AND FREE FIELD } \\
\text { DATA } \\
\text { RR=Round Robin } \\
\text { Surface gages } \\
\text { RTP=Recording } \\
\text { Trailer Park } \\
\text { ONI=Orientaion } \\
\text { to WP Not } \\
\text { Investigated }\end{array}$ \\
\hline DISCUS THROWER & U8a & \begin{tabular}{|l|} 
LANL/DOD, Pre- \\
BANEBERRY, 4 \\
gages in \\
carbonate, 1 gage \\
in argillite, 1 gage \\
at tuff-carbonate \\
interface. \\
\end{tabular} & None & None & None & None & None & $\begin{array}{l}\text { Velocity from Nuclear } \\
\text { Explosions (U)", V. E. } \\
\text { Wheeler, UOPBA 73-44, } \\
3 / 16 / 73, \text {. CFRD report } \\
\text { "Summary of Free Field } \\
\text { Ground Motion } \\
\text { Measurements (U)", V. E. } \\
\text { Wheeler/ R. G. Preston, } \\
\text { UOPBA 74-126, 8/21/74, }\end{array}$ & Sandia report POR 6400 & $\begin{array}{l}\text { Surface, Hor. } \\
\text { dist. (NI) (Ref. } \\
\text { UOPBA 73-44); } \\
\text { Subsurface, } 13 \\
\text { vertical GM } \\
\text { gages (Ref. } \\
\text { UOPBA 74-126) }\end{array}$ \\
\hline DISKO ELM & U12p.03 & LLNL/DOD & 1 Binder & $\begin{array}{l}\text { Raw \& Processed } \\
\text { Data ; CD of ASCII } \\
\text { Processed Data ; } 1 \\
\text { Binder, } 1 \text { Blow } \\
\text { Down Test Binder, }\end{array}$ & 2 Folders & None & None & 1 Presentation Binder & $\begin{array}{l}\text { Leasurements on DISCO } \\
\text { ELM" UCRL-MI-107323 } \\
\text { and UCRL-JC-107323 } \\
\text { (Same Title) and POR } \\
7341 \text { (Same Title) (CDL) }\end{array}$ & \\
\hline DOFINO & U10ba & LLNL & None & $\begin{array}{l}\text { CD of Compressed } \\
\text { Raw \& Processed } \\
\text { Data }\end{array}$ & None & None & Earth Strain Cals. & & None & \\
\hline DOOR MIST & U12g.07 & $\begin{array}{l}\text { LANL/DOD, Pre- } \\
\text { BANEBERRY }\end{array}$ & None & None & None & None & None & $\begin{array}{l}\text { CFRD report "Peak surtace } \\
\text { Velocity from Nuclear } \\
\text { Explosions (U)", V. E. } \\
\text { Wheeler, UOPBA 73-44, } \\
3 / 16 / 73 \text {, }\end{array}$ & None & $\begin{array}{l}\text { Surface, Hor. } \\
\text { dist. (NI) (Ref. } \\
\text { UOPBA 73-44) }\end{array}$ \\
\hline DORMOUSE & U3aq & $\begin{array}{l}\text { LANL, Pre- } \\
\text { BANEBERRY }\end{array}$ & None & None & None & None & None & $\begin{array}{l}\text { Velocity from Nuclear } \\
\text { Explosions (U)", V. E. } \\
\text { Wheeler, UOPBA } 73-44, \\
3 / 16 / 73 \text {, }\end{array}$ & None & $\begin{array}{l}\text { Surface, Hor. } \\
\text { dist. (NI) (Ref. } \\
\text { UOPBA 73-44) }\end{array}$ \\
\hline DORMOUSE PRIME & U3az & $\begin{array}{l}\text { LANL, Pre- } \\
\text { BANEBERRY }\end{array}$ & None & None & None & None & None & $\begin{array}{l}\text { Velocity from Nuclear } \\
\text { Explosions (U)", V. E. } \\
\text { Wheeler, UOPBA 73-44, } \\
3 / 16 / 73 \text {, }\end{array}$ & None & $\begin{array}{l}\text { Surface, Hor. } \\
\text { dist. (NI) (Ref. } \\
\text { UOPBA 73-44) }\end{array}$ \\
\hline
\end{tabular}


Ground Motion Data: Appendix 3B (John Rambo)

\begin{tabular}{|c|c|c|c|c|c|c|c|c|c|c|}
\hline 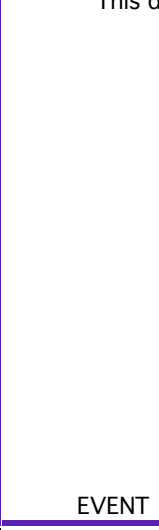 & HOLE & COMMENTS & $\begin{array}{c}\text { DATA } \\
\text { Early LLNL } \\
\text { processed data } \\
\text { and reports } \\
\end{array}$ & $\begin{array}{c}\text { DATA } \\
\begin{array}{c}\text { Later EG\&G } \\
\text { processed data and } \\
\text { reports }\end{array} \\
\end{array}$ & $\begin{array}{c}\text { DATA } \\
-1 \text { Later data } \\
\begin{array}{c}\text { processed at LLNL } \\
\text { by EG\&G }\end{array}\end{array}$ & \begin{tabular}{|c|} 
DATA \\
Data Plots, \\
Surface, \\
Subsurface \\
Ground Motion, \\
Pressure/ \\
Radiation \\
LOS/Displ./ Misc. \\
Similar Items are \\
included in this \\
column.
\end{tabular} & $\begin{array}{c}\text { DATA } \\
\text { Ground Motion at } \\
\text { Distance From } \\
\text { SGZ. Geophone } \\
\text { plots (yellow). }\end{array}$ & 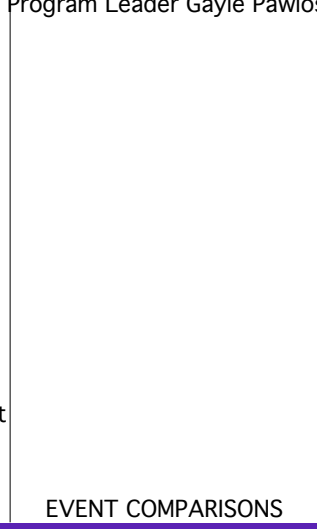 & $\begin{array}{c}\text { SUMMARY AND FINAL } \\
\text { REPORTS } \\
\text { CONF=Classified CFRD } \\
\text { CDR=Containment Data } \\
\text { Report }\end{array}$ & $\begin{array}{c}\text { GSkI@inl.gov). } \\
\text { GAGE } \\
\text { LOCATIONS FOR } \\
\text { FREE SURFACE } \\
\text { AND FREE FIELD } \\
\text { DATA } \\
\text { RR=Round Robin } \\
\text { Surface gages } \\
\text { RTP=Recording } \\
\text { Trailer Park } \\
\text { ONI=Orientaion } \\
\text { to WP Not } \\
\text { Investigated }\end{array}$ \\
\hline DORSAL FIN & U12e.10 & \begin{tabular}{|l|l} 
LANL, Pre- \\
BANEBERRY \\
\end{tabular} & None & None & None & None & None & $\begin{array}{l}\text { Shock Predictions for } \\
\text { Underground Nuclear } \\
\text { Explosions in Rainier Mesa } \\
\text { (U)", L. F. Ingram, J. L. } \\
\text { Drake, DNA-TR-88-14, } \\
10 / 23 / 87, .\end{array}$ & SRI report WT 6282 & $\begin{array}{l}\text { No useable free } \\
\text { field data. (Ref. } \\
\text { DNA-TR-88-14) }\end{array}$ \\
\hline DUMONT & $\mathrm{U} 2 \mathrm{t}$ & \begin{tabular}{|l|} 
LLNL, Pre- \\
BANEBERRY \\
\end{tabular} & 1 Binder & None & None & None & None & None & & \\
\hline DURYEA & U20a & \begin{tabular}{|l} 
LLNL, Pre- \\
BANEBERRY
\end{tabular} & 1 Binder & None & None & None & None & $\begin{array}{l}\text { CFRD report "Peak Surface } \\
\text { Velocity from Nuclear } \\
\text { Explosions (U)", V. E. } \\
\text { Wheeler, UOPBA 73-44, } \\
3 / 16 / 73 \text {, }\end{array}$ & $\begin{array}{l}\text { Surface Motion - Event } \\
\text { DURYEA (U)", H. V. } \\
\text { Hoffman, SRI Project PHU- } \\
6368, \text { UCRL-13305, } \\
8 / 15 / 67, .\end{array}$ & $\begin{array}{l}\text { Surface hor. } \\
\text { Range 50', 600' } \\
900^{\prime} 1800^{\prime} \\
2500^{\prime} .\end{array}$ \\
\hline EAGLE & U9av & $\begin{array}{l}\text { LLNL, Pre- } \\
\text { BANEBERRY }\end{array}$ & None & $\begin{array}{l}\text { CD of Compressed } \\
\text { Raw \& Processed } \\
\text { Data }\end{array}$ & None & None & None & None & & \\
\hline EDAM & U2dy & LLNL & 1 Binder & $\begin{array}{l}\text { CD of Compressed } \\
\text { Raw \& Processed } \\
\text { Data }\end{array}$ & 1 Folder & None & None & None & $\begin{array}{l}\text { GrKD IEPUI RESpUISE OI } \\
\text { the PINEX Pipe and } \\
\text { Ground Surface in EDAM", } \\
\text { V. E. Wheeler/R. G. } \\
\text { Preston, UOPBA 76-36, } \\
\text { 2/24/76, . }\end{array}$ & $\begin{array}{l}\text { Surface hor. } \\
\text { Range (NI) (Ref. } \\
\text { UOPBA 76-36) } \\
\end{array}$ \\
\hline EGMONT & U20al & LLNL & None & $\begin{array}{l}\text { CD of Compressed } \\
\text { Raw \& Processed } \\
\text { Data }\end{array}$ & 1 Folder & None & $\begin{array}{l}\text { None } \\
\text { Uintas }\end{array}$ & $\begin{array}{l}\text { Binder T (CLIPER/EXCOR), } \\
3 \text { Presentation Binders }\end{array}$ & None & \\
\hline EMBUDO & U3hd & LANL & None & None & None & None & \begin{tabular}{|l|} 
report "Round \\
Robin Program \\
ONAJA \& OCATE \\
Events", W. R. \\
Perret, Sandia, \\
No Reference \#, \\
6/25/71 (V). \\
\end{tabular} & $\begin{array}{l}\text { CFRD report "Peak Surface } \\
\text { Velocity from Nuclear } \\
\text { Explosions (U)", V. E. } \\
\text { Wheeler, UOPBA } 73-44, \\
\text { 3/16/73, None }\end{array}$ & None & $\begin{array}{l}\text { Surface (Ref. } \\
\text { RR) Horiz., 25', } \\
497^{\prime}\end{array}$ \\
\hline & U19t & LLNL & & $\begin{array}{l}\text { CD of Compressed } \\
\text { Raw \& Processed } \\
\text { Data }\end{array}$ & 1 Folder & None & None & None & & \\
\hline
\end{tabular}


Ground Motion Data: Appendix 3B (John Rambo)

\begin{tabular}{|c|c|c|c|c|c|c|c|c|c|c|}
\hline This o & des in th & DNT Containmen & $\begin{array}{l}\text { DATA } \\
\text { Early LLNL } \\
\text { processed data } \\
\text { and reports }\end{array}$ & $\begin{array}{c}\text { DATA } \\
\begin{array}{c}\text { Later EG\&G } \\
\text { processed data and } \\
\text { reports }\end{array}\end{array}$ & \begin{tabular}{|c|} 
DATA \\
Later data \\
$\begin{array}{c}\text { processed at LLNL } \\
\text { by EG\&G }\end{array}$
\end{tabular} & $\begin{array}{l}\text { DATA } \\
\text { Data Plots, } \\
\text { Surface, } \\
\text { Subsurface } \\
\text { Ground Motion, } \\
\text { Pressure/ } \\
\text { Radiation } \\
\text { LOS/Displ./ Misc. } \\
\text { Similar Items are } \\
\text { included in this } \\
\text { column. }\end{array}$ & \begin{tabular}{|c|} 
DATA \\
Ground Motion at \\
Distance From \\
SGZ. Geophone \\
plots (yellow).
\end{tabular} & Program Leader Gayle Pan & $\begin{array}{c}\text { SUMMARY AND FINAL } \\
\text { REPORTS } \\
\text { CONF=Classified CFRD } \\
\text { CDR=Containment Data } \\
\text { Report }\end{array}$ & $\begin{array}{c}\text { oski@llnl.gov). } \\
\text { GAGE } \\
\text { LOCATIONS FOR } \\
\text { FREE SURFACE } \\
\text { AND FREE FIELD } \\
\text { DATA } \\
\text { RR=Round Robin } \\
\text { Surface gages } \\
\text { RTP=Recording } \\
\text { Trailer Park } \\
\text { ONI=Orientaion } \\
\text { to WP Not } \\
\text { Investigated }\end{array}$ \\
\hline ERMINE & U3ab & $\begin{array}{l}\text { LANL, Pre- } \\
\text { BANEBERRY } \\
\end{array}$ & None & None & None & None & None & $\begin{array}{l}\text { CFKU report "reak Surrace } \\
\text { Velocity from Nuclear } \\
\text { Explosions (U)", V. E. } \\
\text { Wheeler, UOPBA 73-44, } \\
3 / 16 / 73 \text {, }\end{array}$ & None & $\begin{array}{l}\text { Surface, Hor. } \\
\text { dist. (NI) (Ref. } \\
\text { UOPBA 73-44) }\end{array}$ \\
\hline ESCABOSA & U7ac & LANL & None & None & None & None & Earth Strain Cals. & None & None & \\
\hline ESROM & U7ak & LLNL & None & None & None & None & Earth Strain Cals. & None & None & \\
\hline ESTUARY & U19g & LANL & None & None & None & None & Earth Strain Cals. & None & None & \\
\hline $\begin{array}{l}\text { EVANS } \\
\text { FALLON }\end{array}$ & $\begin{array}{l}\text { U12b.04 } \\
\text { U2dv }\end{array}$ & $\begin{array}{l}\text { LLNL } \\
\text { LLNL }\end{array}$ & \begin{tabular}{|l} 
None \\
None
\end{tabular} & \begin{tabular}{|l} 
None \\
None
\end{tabular} & \begin{tabular}{|l} 
None \\
None
\end{tabular} & \begin{tabular}{|l} 
None \\
None
\end{tabular} & \begin{tabular}{|l} 
None \\
PDS Cals.
\end{tabular} & $\begin{array}{l}\text { CFRD report "Summary of } \\
\text { Free Field Ground Motion } \\
\text { Measurements (U)", V. E. } \\
\text { Wheeler/ R. G. Preston, } \\
\text { UOPBA 74-126, 8/21/74, } \\
\text {. CFRD report "Ground } \\
\text { Shock Predictions for } \\
\text { Underground Nuclear } \\
\text { Explosions in Rainier Mesa } \\
\text { (U)", L. F. Ingram, J. L. } \\
\text { Drake, DNA-TR-88-14, } \\
10 / 23 / 87, . \\
\text { None }\end{array}$ & $\begin{array}{l}\text { Sandia report ITR-1703 } \\
\text { and SRI report WT } 1702 \\
\text { None }\end{array}$ & $\begin{array}{l}\text { Subsurface, } 24 \\
\text { vertical GM } \\
\text { gages (Ref. } \\
\text { UOPBA 74-126), } \\
10 \text { SRI GM } \\
\text { gages, 19 } \\
\text { Sandia GM } \\
\text { gages. (Ref. } \\
\text { DNA-TR-88-14), } \\
\text { (ONI) } \\
\end{array}$ \\
\hline FAULTLESS & U C & $\begin{array}{l}\text { Central Nevada, } \\
\text { LLNL, Pre- } \\
\text { BANEBERRY, WP } \\
\text { in saturated tuff. } \\
9 \text { free field gages } \\
\text { below water } \\
\text { table. } \\
\end{array}$ & None & None & None & None & None & $\begin{array}{l}\text { Velocity from Nuclear } \\
\text { Explosions (U)", V. E. } \\
\text { Wheeler, UOPBA 73-44, } \\
3 / 16 / 73, \text {. CFRD report } \\
\text { "Summary of Free Field } \\
\text { Ground Motion } \\
\text { Measurements (U)", V. E. } \\
\text { Wheeler/ R. G. Preston, } \\
\text { UOPBA 74-126, 8/21/74, }\end{array}$ & $\begin{array}{l}\text { Sandia report, SC-TM 68- } \\
108\end{array}$ & $\begin{array}{l}\text { Surface, Hor. } \\
\text { dist. (NI) (Ref. } \\
\text { UOPBA 73-44); } \\
\text { Subsurface, } 2 \\
\text { shot level GM } \\
\text { gages, } 11 \\
\text { vertical GM } \\
\text { gages (Ref. } \\
\text { UOPBA 74-126) }\end{array}$ \\
\hline FARALLONES & U2fa & LLNL & None & $\begin{array}{l}\text { CD of Compressed } \\
\text { Raw \& Processed } \\
\text { Data }\end{array}$ & None & None & $\begin{array}{l}\text { Pathfinder CD of } \\
\text { Compressed Raw } \\
\& \text { Processed } \\
\text { Data }(\mathrm{V}) \\
\end{array}$ & None & None & \\
\hline
\end{tabular}


Ground Motion Data: Appendix 3B (John Rambo)

\begin{tabular}{|c|c|c|c|c|c|c|c|c|c|c|}
\hline This da & ides in the LL & DNT Containme & $\begin{array}{c}\text { DATA } \\
\text { Early LLNL } \\
\text { processed data } \\
\text { and reports }\end{array}$ & $\begin{array}{c}\text { DATA } \\
\begin{array}{c}\text { Later EG\&G } \\
\text { processed data and } \\
\text { reports }\end{array} \\
\end{array}$ & \begin{tabular}{|c} 
DATA \\
Later data \\
processed at LLNL \\
by EG\&G
\end{tabular} & \begin{tabular}{|c|} 
DATA \\
Data Plots, \\
Surface, \\
Subsurface \\
Ground Motion, \\
Pressure/ \\
Radiation \\
LOS/Displ./ Misc. \\
Similar Items are \\
included in this \\
column. \\
\end{tabular} & \begin{tabular}{|c|} 
DATA \\
Ground Motion at \\
Distance From \\
SGZ. Geophone \\
plots (yellow).
\end{tabular} & Program Leader Gayle Pawlo & $\begin{array}{c}\text { SUMMARY AND FINAL } \\
\text { REPORTS } \\
\text { CONF=Classified CFRD } \\
\text { CDR=Containment Data } \\
\text { Report }\end{array}$ & $\begin{array}{l}\text { gski@llnl.gov). } \\
\text { GAGE } \\
\text { LOCATIONS FOR } \\
\text { FREE SURFACE } \\
\text { AND FREE FIELD } \\
\text { DATA } \\
\text { RR=Round Robin } \\
\text { Surface gages } \\
\text { RTP=Recording } \\
\text { Trailer Park } \\
\text { ONI=Orientaion } \\
\text { to WP Not } \\
\text { Investigated }\end{array}$ \\
\hline FARM & U20ab & LLNL & None & $\begin{array}{l}\text { CD of Compressed } \\
\text { Raw \& Processed } \\
\text { Data; CD of ASCII } \\
\text { Processed Data; } 1 \\
\text { Binder }\end{array}$ & 1 Folder & None & Earth Strain Cals. & None & $\begin{array}{l}\text { "Ground Motion on FARM } \\
\text { Event" UOPKL 79-64 ; } \\
\text { UCRL-ID-128957 (CDR) }\end{array}$ & $\begin{array}{l}\text { Dist. 100', } \\
1021 \text { ' (Ref. } \\
\text { CDR): } \\
\text { Subsurface, No } \\
\text { free field gages, } \\
\text { no GM gages in } \\
\text { Plugs (Ref. CDR) }\end{array}$ \\
\hline FISHER & U3ah & $\begin{array}{l}\text { LANL, Pre- } \\
\text { BANEBERRY }\end{array}$ & None & & None & None & None & $\begin{array}{l}\text { Velocity from Nuclear } \\
\text { Explosions (U)", V. E. } \\
\text { Wheeler, UOPBA 73-44, } \\
3 / 16 / 73, \text {. CFRD report } \\
\text { "Summary of Free Field } \\
\text { Ground Motion } \\
\text { Measurements (U)", V. E. } \\
\text { Wheeler/ R. G. Preston, } \\
\text { UOPBA 74-126, 8/21/74, }\end{array}$ & Sandia report VUF-2000 & $\begin{array}{l}\text { Surface, Hor. } \\
\text { dist. (NI) (Ref. } \\
\text { UOPBA 73-44); } \\
\text { Subsurface, } 6 \\
\text { GM gages. (Ref. } \\
\text { UOPBA 74-126) }\end{array}$ \\
\hline $\begin{array}{l}\text { FLASK GREEN } \\
\text { FLASK RED } \\
\text { FLASK YELLOW }\end{array}$ & $\begin{array}{l}\text { U2az } 1 \text { U2az } 3 \\
\text { U2az } 2\end{array}$ & Pre-BANEBERRY & None & $\begin{array}{l}\text { CD of Compressed } \\
\text { Raw \& Processed } \\
\text { Data }\end{array}$ & None & None & None & & None & \\
\hline FLAX BACKUP & U2dj & $\begin{array}{l}\text { LLNL, } \\
\text { simultaneous, } \\
\text { same hole. } \\
\text { Alluvium. } \\
\end{array}$ & 13 Binders & $\begin{array}{l}\text { CD of Compressed } \\
\text { Raw \& Processed } \\
\text { Data }\end{array}$ & 1 Folders & None & \begin{tabular}{|l|} 
\\
\\
\\
\\
Pathfinder II, \\
and CNSI report \\
"Round Robin \\
Program FLAX \\
Event (U)", W. R. \\
Perret, Sandia \\
UOPBA 73-11, \\
1/15/73 (V) \\
\end{tabular} & $\begin{array}{l}\text { Binders B, L, U, and CFRD } \\
\text { report "Summary of Free } \\
\text { Field Ground Motion } \\
\text { Measurments(U)", V. E. } \\
\text { Wheeler/ R. G. Preston, } \\
\text { UOPBA 74-126, 8/21/74. } \\
\text { CFRD report "Trapped } \\
\text { Stress Waves in } \\
\text { Underground Nuclear } \\
\text { Explosions (U)", V. E. } \\
\text { Wheeler, R. G. Preston, C. } \\
\text { E. Frerking, UCRL-52012, . } \\
\text { CFRD report "Peak Surface } \\
\text { Velocity from Nuclear } \\
\text { Explosions (U)", V. E. } \\
\text { Wheeler, UOPBA 73-44, } \\
3 / 16 / 73, \\
\end{array}$ & $\begin{array}{l}\text { CFRD report "Stemming } \\
\text { Motion and Probable Dud } \\
\text { Plug Failure on FLAX (U)", } \\
\text { V. E. Wheeler, UOPBA 73- } \\
27,2 / 12 / 73 . \\
\text { "Calculations of the FLAX } \\
\text { Events with Comparisons } \\
\text { to Particle Velocity Data } \\
\text { Recorded at Low Stress" } \\
\text { J. T. Rambo, Proceeding } \\
\text { of the 7th Containment } \\
\text { Symposium, Vol. 2, Boing } \\
\text { Space Center, Kent, WA, } \\
8 / 2-4 / 83 \text {. } \\
\end{array}$ & $\begin{array}{l}\text { Surface (Ref. } \\
\text { RR) hor. Range } \\
51 ', 1129 \text { ' and } \\
1130 \text { '; } \\
\text { Subsurface, } 13 \\
\text { offset vertical } \\
\text { GM gages. Some } \\
\text { free field GM } \\
\text { gages used for } \\
\text { both FLAX } \\
\text { events. Some } \\
\text { stemming gages } \\
\text { (Ref. UOPBA 74- } \\
126) \\
\end{array}$ \\
\hline
\end{tabular}




\begin{tabular}{|c|c|c|c|c|c|c|c|c|c|c|}
\hline This d & ides in th & DNT Containm & $\begin{array}{c}\text { DATA } \\
\text { Early LLNL } \\
\text { processed data } \\
\text { and reports }\end{array}$ & $\begin{array}{c}\text { DATA } \\
\begin{array}{c}\text { Later EG\&G } \\
\text { processed data and } \\
\text { reports }\end{array} \\
\end{array}$ & \begin{tabular}{|c} 
DATA \\
Later data \\
processed at LLNL \\
by EG\&G
\end{tabular} & $\begin{array}{c}\text { DATA } \\
\text { Data Plots, } \\
\text { Surface, } \\
\text { Subsurface } \\
\text { Ground Motion, } \\
\text { Pressure/ } \\
\text { Radiation } \\
\text { LOS/Displ./ Misc. } \\
\text { Similar Items are } \\
\text { included in this } \\
\text { column. }\end{array}$ & $\begin{array}{c}\text { DATA } \\
\text { Ground Motion at } \\
\text { Distance From } \\
\text { SGZ. Geophone } \\
\text { plots (yellow). }\end{array}$ & Program Leader Gayle Pawlo & $\begin{array}{c}\text { SUMMARY AND FINAL } \\
\text { REPORTS } \\
\text { CONF=Classified CFRD } \\
\text { CDR=Containment Data } \\
\text { Report }\end{array}$ & $\begin{array}{c}\text { ski@llnl.gov). } \\
\text { GAGE } \\
\text { LOCATIONS FOR } \\
\text { FREE SURFACE } \\
\text { AND FREE FIELD } \\
\text { DATA } \\
\text { RR=Round Robin } \\
\text { Surface gages } \\
\text { RTP=Recording } \\
\text { Trailer Park } \\
\text { ONI=Orientaion } \\
\text { to WP Not } \\
\text { Investigated }\end{array}$ \\
\hline FLAX SOURCE & U2dj & $\begin{array}{l}\text { LLNL, } \\
\text { simultaneous, } \\
\text { same hole. Tuff }\end{array}$ & 14 Binders & $\begin{array}{l}\text { CD of Compressed } \\
\text { Raw \& Processed } \\
\text { Data }\end{array}$ & 2 Folders & None & \begin{tabular}{|l|} 
\\
\\
Pathfinder II, \\
and CNSI report \\
"Round Robin \\
Program FLAX \\
Event (U)", W. R. \\
Perret, Sandia \\
UOPBA 73-11, \\
1/15/73 (V) \\
\end{tabular} & $\begin{array}{l}\text { Binders B, L, O, and CFRD } \\
\text { report "Summary of Free } \\
\text { Field Ground Motion } \\
\text { Measurments(U)", V. E. } \\
\text { Wheeler/ R. G. Preston, } \\
\text { UOPBA 74-126, 8/21/74. } \\
\text { CFRD report "Trapped } \\
\text { Stress Waves in } \\
\text { Underground Nuclear } \\
\text { Explosions (U)", V. E. } \\
\text { Wheeler, R. G. Preston, C. } \\
\text { E. Frerking, UCRL-52012, . } \\
\text { CFRD report "Peak Surface } \\
\text { Velocity from Nuclear } \\
\text { Explosions (U)", V. E. } \\
\text { Wheeler, UOPBA 73-44, } \\
\end{array}$ & $\begin{array}{l}\text { CFRD report "Stemming } \\
\text { Motion and Probable Dud } \\
\text { Plug Failure on FLAX (U)", } \\
\text { V. E. Wheeler, UOPBA 73- } \\
27,2 / 12 / 73 . \\
\text { "Calculations of the FLAX } \\
\text { Events with Comparisons } \\
\text { to Particle Velocity Data } \\
\text { Recorded at Low Stress" } \\
\text { J. T. Rambo, Proceeding } \\
\text { of the 7th Containment } \\
\text { Symposium, Vol. 2, Boing } \\
\text { Space Center, Kent, WA, } \\
\text { 8/2-4/83. }\end{array}$ & $\begin{array}{l}\text { Surface (Ref. } \\
\text { RR) hor. Range } \\
511^{\prime}, 1129^{\prime} \text { and } \\
1130^{\prime} ; \\
\text { Subsurface, } 21 \\
\text { offset vertical } \\
\text { GM gages. Some } \\
\text { free field GM } \\
\text { gages used for } \\
\text { both FLAX } \\
\text { events. Some } \\
\text { stremming } \\
\text { gages. (Ref. } \\
\text { UOPBA 74-126) }\end{array}$ \\
\hline FLOTOST & U2ao & LLNL & None & $\begin{array}{l}\text { CD of Compressed } \\
\text { Raw \& Processed } \\
\text { Data }\end{array}$ & None & None & None & Binder T (CLIPER/EXCOR) & None & \\
\hline FONDUTTA & U19z S & LLNL & None & $\begin{array}{l}\text { Raw \& Processed } \\
\text { Data }\end{array}$ & None & None & Earth Strain Cals. & Binder T (CLIPER/EXCOR) & None & \\
\hline FONTINA & U2Of & LLNL & None & None & None & None & Earth Strain Cals. & None & None & \\
\hline FRISCO & U8m & LLNL & None & $\begin{array}{l}\text { CD of Compressed } \\
\text { Raw \& Processed } \\
\text { Data ; CD of ASCII } \\
\text { Processed Data ; } 1 \\
\text { Binder }\end{array}$ & 1 Folder & $\begin{array}{l}1 \text { Ground Motion } \\
\text { Roll (Blue), } 1 \\
\text { Plug/Pipe } \\
\text { Displacement Roll } \\
\text { (Green) }\end{array}$ & None & \begin{tabular}{|l} 
Binder U (Peak \\
Acceleration of Trailers), \\
Binder T (CLIPER/EXCOR)
\end{tabular} & $\begin{array}{l}\text { Draft Report "Motion Near } \\
\text { the Top of the } \\
\text { Emplacement: FRISCO } \\
\text { Event" ; UCRL-ID-125016 } \\
\text { (CDR) }\end{array}$ & $\begin{array}{l}\text { Dist. 50', RTP } \\
\text { (Ref. CDR): } \\
\text { Subsurface, No } \\
\text { free field gages, } \\
1 \text { GM gage in } \\
\text { Plug (Ref. CDR) }\end{array}$ \\
\hline GALENA & U9cv & LLNL & None & $\begin{array}{l}\text { CD of Compressed } \\
\text { Raw \& Processed } \\
\text { Data; CD of ASCII } \\
\text { Processed Data; } 2 \\
\text { Binders } \\
\end{array}$ & 1 Folder & None & None & 2 Presentation Binders & UCRL-MI-111644 (CDR) & $\begin{array}{l}\text { Dist. 50', RTP } \\
\text { (Ref. CDR): } \\
\text { Subsurface, No } \\
\text { free field gages, } \\
\text { No GM gages in } \\
\text { Plugs (Ref. CDR) }\end{array}$ \\
\hline
\end{tabular}


Ground Motion Data: Appendix 3B (John Rambo)

\begin{tabular}{|c|c|c|c|c|c|c|c|c|c|c|}
\hline This o & ides in th & DNT Containment & $\begin{array}{c}\text { DATA } \\
\text { Early LLNL } \\
\text { processed data } \\
\text { and reports }\end{array}$ & $\begin{array}{c}\text { DATA } \\
\begin{array}{c}\text { Later EG\&G } \\
\text { processed data and } \\
\text { reports }\end{array}\end{array}$ & \begin{tabular}{|c} 
DATA \\
Later data \\
processed at LLNL \\
by EG\&G
\end{tabular} & \begin{tabular}{|c|} 
DATA \\
Data Plots, \\
Surface, \\
Subsurface \\
Ground Motion, \\
Pressure/ \\
Radiation \\
LOS/Displ./ Misc. \\
Similar Items are \\
included in this \\
column. \\
\end{tabular} & \begin{tabular}{|c|} 
DATA \\
Ground Motion at \\
Distance From \\
SGZ. Geophone \\
plots (yellow).
\end{tabular} & Program Leader Gayle Pawl & $\begin{array}{c}\text { SUMMARY AND FINAL } \\
\text { REPORTS } \\
\text { CONF=Classified CFRD } \\
\text { CDR=Containment Data } \\
\text { Report }\end{array}$ & $\begin{array}{c}\text { ski@llnl.gov). } \\
\text { GAGE } \\
\text { LOCATIONS FOR } \\
\text { FREE SURFACE } \\
\text { AND FREE FIELD } \\
\text { DATA } \\
\text { RR=Round Robin } \\
\text { Surface gages } \\
\text { RTP=Recording } \\
\text { Trailer Park } \\
\text { ONI=Orientaion } \\
\text { to WP Not } \\
\text { Investigated } \\
\end{array}$ \\
\hline GALVESTON & U19af & LANL & None & $\begin{array}{l}\text { CD of Compressed } \\
\text { Raw \& Processed } \\
\text { Data; CD of ASCII } \\
\text { Processed Data; } 1 \\
\text { Binder }\end{array}$ & 1 Folder & None & None & None & None & \\
\hline GASBUGGY & ONM RIO & $\begin{array}{l}\text { LLNL, Pre- } \\
\text { BANEBERRY, } \\
\text { Farmington NM, } \\
\text { Gas Stimulation } \\
\text { Test, WP in Shale, } \\
2 \text { free field gages } \\
\text { in shale, } 2 \text { free } \\
\text { field gages in } \\
\text { sandstone }\end{array}$ & None & $\begin{array}{l}\text { CD of Compressed } \\
\text { Raw \& Processed } \\
\text { Data }\end{array}$ & None & None & None & $\begin{array}{l}\text { CFRD report "Peak Surface } \\
\text { Velocity from Nuclear } \\
\text { Explosions (U)", V. E. } \\
\text { Wheeler, UOPBA 73-44, } \\
3 / 16 / 73, \text {. CFRD report } \\
\text { "Summary of Free Field } \\
\text { Ground Motion } \\
\text { Measurements (U)", V. E. } \\
\text { Wheeler/ R. G. Preston, } \\
\text { UOPBA 74-126, 8/21/74, } \\
\end{array}$ & Sandia report PNE 1002 & $\begin{array}{l}\text { Surface, Hor. } \\
\text { dist. (NI) (Ref. } \\
\text { UOPBA 73-44); } \\
\text { Subsurface, } 5 \\
\text { offset vertical } \\
\text { GM gages. (Ref. } \\
\text { UOPBA 74-126) }\end{array}$ \\
\hline GASCON & $\mathrm{U} 4 \mathrm{t}$ & LANL & None & $\begin{array}{l}\text { CD of Compressed } \\
\text { Raw \& Processed } \\
\text { Data; CD of ASCII } \\
\text { Processed Data; } 1 \\
\text { Binder }\end{array}$ & None & None & None & None & None & \\
\hline GAZOOK & U2do & LLNL & 3 Binders & $\begin{array}{l}\text { CD of Compressed } \\
\text { Raw \& Processed } \\
\text { Data }\end{array}$ & 1 Folder & None & Round Robin & Binder B & None & \\
\hline GIBNE & U20ah & LLNL & None & $\begin{array}{l}\text { CD of Compressed } \\
\text { Raw \& Processed } \\
\text { Data }\end{array}$ & 1 Folder & $\begin{array}{l}1 \text { Wide Ground } \\
\text { Motion Roll (Blue) }\end{array}$ & $\begin{array}{l}1 \text { Geophone Roll } \\
\text { (Yellow) }\end{array}$ & None & None & \\
\hline GNOME & ONM EDY & $\begin{array}{l}\text { LLNL/DOD, Pre- } \\
\text { BANEBERRY, } \\
\text { Carlsbad NM, WP } \\
\text { in salt } \\
\end{array}$ & None & None & None & None & None & $\begin{array}{l}\text { Velocity from Nuclear } \\
\text { Explosions (U)", V. E. } \\
\text { Wheeler, UOPBA 73-44, } \\
3 / 16 / 73, . \text { CFRD report } \\
\text { "Summary of Free Field } \\
\text { Ground Motion } \\
\text { Measurements (U)", V. E. } \\
\text { Wheeler/ R. G. Preston, } \\
\text { UOPBA 74-126, 8/21/74, }\end{array}$ & $\begin{array}{l}\text { Sandia report, PNE } 108 \mathrm{~F} \text {. } \\
\text { Sandia report, PNE } 111 \mathrm{~F}\end{array}$ & $\begin{array}{l}\text { Surface, Hor. } \\
\text { dist. (NI) (Ref. } \\
\text { UOPBA 73-44); } \\
\text { Subsurface, } 21 \\
\text { shot level GM } \\
\text { gages, } 7 \text { vertical } \\
\text { GM gages (Ref. } \\
\text { UOPBA 74-126) } \\
\end{array}$ \\
\hline
\end{tabular}


Ground Motion Data: Appendix 3B (John Rambo)

\begin{tabular}{|c|c|c|c|c|c|c|c|c|c|c|}
\hline 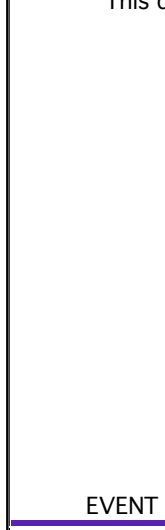 & HOLE & COMMENTS & $\begin{array}{c}\text { DATA } \\
\text { Early LLNL } \\
\text { processed data } \\
\text { and reports } \\
\end{array}$ & $\begin{array}{c}\text { DATA } \\
\begin{array}{c}\text { Later EG\&G } \\
\text { processed data and } \\
\text { reports }\end{array} \\
\end{array}$ & \begin{tabular}{|c} 
DATA \\
Later data \\
processed at LLNL \\
by EG\&G
\end{tabular} & $\begin{array}{c}\text { DATA } \\
\text { Data Plots, } \\
\text { Surface, } \\
\text { Subsurface } \\
\text { Ground Motion, } \\
\text { Pressure/ } \\
\text { Radiation } \\
\text { LOS/Displ./ Misc. } \\
\text { Similar Items are } \\
\text { included in this } \\
\text { column. }\end{array}$ & \begin{tabular}{|c|} 
DATA \\
Ground Motion at \\
Distance From \\
SGZ. Geophone \\
plots (yellow).
\end{tabular} & 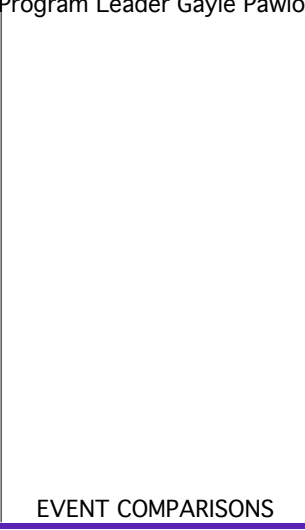 & $\begin{array}{c}\text { SUMMARY AND FINAL } \\
\text { REPORTS } \\
\text { CONF=Classified CFRD } \\
\text { CDR=Containment Data } \\
\text { Report }\end{array}$ & $\begin{array}{c}\text { GAGE } \\
\text { LOCATIONS FOR } \\
\text { FREE SURFACE } \\
\text { AND FREE FIELD } \\
\text { DATA } \\
\text { RR=Round Robin } \\
\text { Surface gages } \\
\text { RTP=Recording } \\
\text { Trailer Park } \\
\text { ONI=Orientaion } \\
\text { to WP Not } \\
\text { Investigated }\end{array}$ \\
\hline GOUDA & U2ef & LLNL & 2 Binders & $\begin{array}{l}\text { CD of Compressed } \\
\text { Raw \& Processed } \\
\text { Data }\end{array}$ & 1 Folder & \begin{tabular}{|l|} 
Is Ground \\
Motion Rolls \\
(Blue), 1 Data \\
List of Channels \\
$0-14$
\end{tabular} & Earth Strain Cals. & 2 Presentation Binders & None & \\
\hline GREELEY & U20g & $\begin{array}{l}\text { LLNL, Pre- } \\
\text { BANEBERRY } \\
\end{array}$ & 1 Binder & None & None & None & None & $\begin{array}{l}\text { CFRD report "Peak surtace } \\
\text { Velocity from Nuclear } \\
\text { Explosions (U)", V. E. } \\
\text { Wheeler, UOPBA 73-44, } \\
3 / 16 / 73 \text {, }\end{array}$ & None & $\begin{array}{l}\text { Surface, Hor. } \\
\text { dist. (NI) (Ref. } \\
\text { UOPBA 73-44) }\end{array}$ \\
\hline GROVE & U2ds & LLNL & 3 Binders & $\begin{array}{l}\text { CD of Compressed } \\
\text { Raw \& Processed } \\
\text { Data }\end{array}$ & 1 Folder & None & None & $\begin{array}{l}\text { Binders } \mathrm{B}, \mathrm{H}, 2 \\
\text { Presentation Binders }\end{array}$ & None & \\
\hline GRUYERE & U9cg & LLNL & 2 Binders & $\begin{array}{l}\text { CD of Compressed } \\
\text { Raw \& Processed } \\
\text { Data }\end{array}$ & 1 Folder & None & None & None & None & \\
\hline HALFBEAK & U19b & $\begin{array}{l}\text { LANL, Pre- } \\
\text { BANEBERRY, Very } \\
\text { high surface } \\
\text { motion. }\end{array}$ & None & None & None & None & None & $\begin{array}{l}\text { Velocity from Nuclear } \\
\text { Wheeler, UOPBA } 73-44 \text {, } \\
3 / 16 / 73 \text {, }\end{array}$ & None & $\begin{array}{l}\text { Surface, Hor. } \\
\text { dist. (NI) (Ref. } \\
\text { UOPBA 73-44) }\end{array}$ \\
\hline HANDCAR & U10b & $\begin{array}{l}\text { LLNL, Pre- } \\
\text { BANEBERRY,WP in } \\
\text { Pz Dolomite, } 6 \\
\text { gages in } \\
\text { carbonate, } 4 \\
\text { gages in shale } \\
\end{array}$ & None & None & None & None & None & $\begin{array}{l}\text { CFRD report "Peak Surface } \\
\text { Velocity from Nuclear } \\
\text { Explosions (U)", V. E. } \\
\text { Wheeler, UOPBA 73-44, } \\
\text { 3/16/73, . CFRD report } \\
\text { "Summary of Free Field } \\
\text { Ground Motion } \\
\text { Measurements (U)", V. E. } \\
\text { Wheeler/ R. G. Preston, } \\
\text { UOPBA 74-126, 8/21/74, }\end{array}$ & $\begin{array}{l}2 \text { reports "Ground Motion } \\
\text { in a Multilayered Earth } \\
\text { Part I: Nulear Explosion in } \\
\text { Hard Rock" and Sandia } \\
\text { report POR } 2800\end{array}$ & $\begin{array}{l}\text { Surface, Hor. } \\
\text { dist. (NI) (Ref. } \\
\text { UOPBA 73-44); } \\
\text { Subsurface, } 16 \\
\text { offset vertical } \\
\text { GM gages. (Ref. } \\
\text { UOPBA 74-126) }\end{array}$ \\
\hline HANDLEY & $\mathrm{U} 20 \mathrm{~m}$ & $\begin{array}{l}\text { LLNL, Pre- } \\
\text { BANEBERRY } \\
\end{array}$ & 4 Binders & $\begin{array}{l}\text { CD of Compressed } \\
\text { Raw \& Processed } \\
\text { Data; CD of ASCII } \\
\text { Processed Data } \\
\end{array}$ & 1 Folder & $\begin{array}{l}\text { I box with L } \\
\text { Ground Motion or } \\
\text { Geophone Rolls } \\
\text { (Traces) + Other } \\
\text { Traces }\end{array}$ & $\begin{array}{l}1 \text { Box with } 2 \\
\text { Possible } \\
\text { Geophone Rolls } \\
\text { (Traces) }\end{array}$ & 1 Presentation Binder & \begin{tabular}{|l|} 
Draft Report "HANDLEY \\
Ground Motion Raw Data"
\end{tabular} & \\
\hline
\end{tabular}


Ground Motion Data: Appendix 3B (John Rambo)

\begin{tabular}{|c|c|c|c|c|c|c|c|c|c|c|}
\hline This o & des in the & DNT Containme & $\begin{array}{c}\text { DATA } \\
\text { Early LLNL } \\
\text { processed data } \\
\text { and reports }\end{array}$ & $\begin{array}{c}\text { DATA } \\
\begin{array}{c}\text { Later EG\&G } \\
\text { processed data and } \\
\text { reports }\end{array}\end{array}$ & $\begin{array}{c}\text { DATA } \\
\text { - Later data } \\
\text { processed at LLNL } \\
\text { by EG\&G }\end{array}$ & \begin{tabular}{|c} 
DATA \\
-_-_-_-- \\
Data Plots, \\
Surface, \\
Subsurface \\
Ground Motion, \\
Pressure/ \\
Radiation \\
LOS/Displ./ Misc. \\
Similar Items are \\
included in this \\
column.
\end{tabular} & $\begin{array}{c}\text { DATA } \\
\text { Ground Motion at } \\
\text { Distance From } \\
\text { SGZ. Geophone } \\
\text { plots (yellow). }\end{array}$ & Program Leader Gayle Pawlo & $\begin{array}{c}\text { SUMMARY AND FINAL } \\
\text { REPORTS } \\
\text { CONF=Classified CFRD } \\
\text { CDR=Containment Data } \\
\text { Report }\end{array}$ & $\begin{array}{l}\text { oski@llnl.gov). } \\
\text { GAGE } \\
\text { LOCATIONS FOR } \\
\text { FREE SURFACE } \\
\text { AND FREE FIELD } \\
\text { DATA } \\
\text { RR=Round Robin } \\
\text { Surface gages } \\
\text { RTP=Recording } \\
\text { Trailer Park } \\
\text { ONI=Orientaion } \\
\text { to WP Not } \\
\text { Investigated }\end{array}$ \\
\hline HARDHAT & U15a & 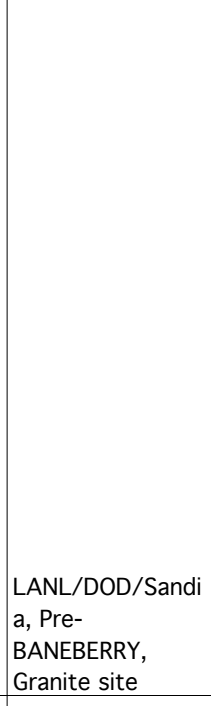 & None & None & None & None & None & $\begin{array}{l}\text { Field Peak Radial Stresses } \\
\text { from Underground Nuclear } \\
\text { Explosiona in Five Explosion } \\
\text { Media (U)", V. E. Wheeler/ } \\
\text { R. G. Preston, UOPKG 66- } \\
\text { 80, 12,/7/66, . Free-Field } \\
\text { Peak Particle Velocities and } \\
\text { Stresses fron Underground } \\
\text { Nuclear Explosions in a } \\
\text { LONGSHOT - type } \\
\text { Environment, R. G. Preston, } \\
\text { UOPKG 67-18, 4/26/67. } \\
\text { CFRD report "Peak Surface } \\
\text { Velocity from Nuclear } \\
\text { Explosions (U)", V. E. } \\
\text { Wheeler, UOPBA 73-44, } \\
\text { 3/16/73, . CFRD report } \\
\text { "Summary of Free Field } \\
\text { Ground Motion } \\
\text { Measurements (U)", V. E. } \\
\text { Wheeler/ R. G. Preston, } \\
\text { UOPBA 74-126, 8/21/74, }\end{array}$ & (1) & $\begin{array}{l}\text { Surface, Hor. } \\
\text { dist. (NI) (Ref. } \\
\text { UOPBA 73-44); } \\
\text { Subsurface, } 15 \\
\text { shot level GM } \\
\text { gages, } 7 \text { vertical } \\
\text { GM gages (Ref. } \\
\text { UOPBA 74-126) }\end{array}$ \\
\hline HARDIN & U20av & LLNL & None & \begin{tabular}{|l|} 
CD of Compressed \\
Raw \& Processed \\
Data; CD of ASCII \\
Processed Data; 1 \\
Binder \\
\end{tabular} & 1 Folder & $\begin{array}{l}6 \text { Ground Motion } \\
\text { Rolls in Box }\end{array}$ & $\begin{array}{l}\text { DELAMAR } \\
\text { Induced Ground } \\
\text { Motion at the } \\
\text { HARDIN SIte } \\
\text { UCID-21151 Rev } \\
1(\mathrm{CL}) \\
\end{array}$ & $\begin{array}{l}\text { Binder U (Peak } \\
\text { Accelleration of Trailers), } 2 \\
\text { Presentation Binders }\end{array}$ & $\begin{array}{l}\text { "DELAMAR Induced } \\
\text { Ground Motion at the } \\
\text { HARDIN Site" UCID-21151 } \\
\text { Rev } 1 \text {; "Ground Motion in } \\
\text { a Layered Medium: The } \\
\text { HARDIN Event" UCRL-ID- } \\
\text { H } 07812 \text { (Conf.) }\end{array}$ & \\
\hline
\end{tabular}


Ground Motion Data: Appendix 3B (John Rambo)

\begin{tabular}{|c|c|c|c|c|c|c|c|c|c|c|}
\hline This 0 & ides in th & DNT Containm & Program files. Prog & $\begin{array}{c}\text { DATA } \\
\begin{array}{c}\text { Later EG\&G } \\
\text { processed data and } \\
\text { reports }\end{array} \\
\end{array}$ & $\begin{array}{c}\text { DATA } \\
-1 \text { Later data } \\
\begin{array}{c}\text { processed at LLNL } \\
\text { by EG\&G }\end{array} \\
\end{array}$ & \begin{tabular}{|c|} 
DATA \\
Data Plots, \\
Surface, \\
Subsurface \\
Ground Motion, \\
Pressure/ \\
Radiation \\
LOS/Displ./ Misc. \\
Similar Items are \\
included in this \\
column.
\end{tabular} & $\begin{array}{c}\text { DATA } \\
\text { Ground Motion at } \\
\text { Distance From } \\
\text { SGZ. Geophone } \\
\text { plots (yellow). }\end{array}$ & Program Leader Gayle Pawlo & $\begin{array}{c}\text { SUMMARY AND FINAL } \\
\text { REPORTS } \\
\text { CONF=Classified CFRD } \\
\text { CDR=Containment Data } \\
\text { Report }\end{array}$ & $\begin{array}{l}\text { ski@llnl.gov). } \\
\text { GAGE } \\
\text { LOCATIONS FOR } \\
\text { FREE SURFACE } \\
\text { AND FREE FIELD } \\
\text { DATA } \\
\text { RR=Round Robin } \\
\text { Surface gages } \\
\text { RTP=Recording } \\
\text { Trailer Park } \\
\text { ONl=Orientaion } \\
\text { to WP Not } \\
\text { Investigated }\end{array}$ \\
\hline HAREBELL & U2br & LLNL & 9 Binders & $\begin{array}{l}\text { CD of Compressed } \\
\text { Raw \& Processed } \\
\text { Data }\end{array}$ & 1 Folder & None & $\begin{array}{l}\text { Pathfinder II ; } 1 \\
\text { Wide Geophone } \\
\text { Roll (Yellow) }\end{array}$ & $\begin{array}{l}\text { BInders A, B, H, L, U, and } \\
\text { CFRD report "Trapped } \\
\text { Stress Waves in } \\
\text { Underground Nuclear } \\
\text { Explosions (U)", V. E. } \\
\text { Wheeler, R. G. Preston, C. } \\
\text { E. Frerking, UCRL-52012, . } \\
\text { CFRD report "Peak Surface } \\
\text { Velocity from Nuclear } \\
\text { Explosions (U)", V. E. } \\
\text { Wheeler, UOPBA 73-44, } \\
\text { 3/16/73, . CFRD report } \\
\text { "Summary of Free Field } \\
\text { Ground Motion } \\
\text { Measurements (U)", V. E. } \\
\text { Wheeler/ R. G. Preston, } \\
\text { UOPBA 74-126, 8/21/74, }\end{array}$ & \begin{tabular}{|l|} 
EGG Report "Report of \\
Surface-Motion \\
Measurements in \\
HAREBELL" ASD-72-255 \\
; "A Summary of the \\
HAREBELL Containment \\
Diagnostics", UOPBA 73- \\
40 ; "Response of the \\
LOS Pipe in the HAREBELL \\
Underground Nuclear \\
Test" UOPBA 72-19 \\
\end{tabular} & $\begin{array}{l}\text { Surface, Hor. } \\
\text { dist. (NI) (Ref. } \\
\text { UOPBA 73-44); } \\
\text { Subsurface, } \\
\text { stemming gages } \\
\text { (Ref. UOPBA 74- } \\
\text { 126) }\end{array}$ \\
\hline HARZER & U19aj & LLNL & None & $\begin{array}{l}\text { CD of Compressed } \\
\text { Raw \& Processed } \\
\text { Data }\end{array}$ & 1 Folder & None & None & None & None & \\
\hline HAVARTI & U10bg & LLNL & None & $\begin{array}{l}\text { CD of Compressed } \\
\text { Raw \& Processed } \\
\text { Data; CD of ASCII } \\
\text { Processed Data; } 1 \\
\text { Binder } \\
\end{array}$ & 1 Folder & $\begin{array}{l}1 \text { Ground Motion } \\
\text { Roll (Blue) }\end{array}$ & None & $\begin{array}{l}\text { Binder U (Peak } \\
\text { Accelleration of Trailers), } 1 \\
\text { Presentation Binder }\end{array}$ & $\begin{array}{l}\text { "Motion Measured on } \\
\text { HAVARTI by Containment } \\
\text { Instrumentation" UOPKL } \\
81-76 ; \text { UCRL-ID-127720 } \\
\text { (CDR) }\end{array}$ & $\begin{array}{l}\text { Dist. 50', RTP } \\
\text { (Ref. CDR): } \\
\text { Subsurface, No } \\
\text { free field gages, } \\
1 \text { GM gage in } \\
\text { Plug (Ref. CDR) }\end{array}$ \\
\hline HAYMAKER & U3au-S & $\begin{array}{l}\text { LANL, Pre- } \\
\text { BANEBERRY } \\
\end{array}$ & None & None & None & None & None & $\begin{array}{l}\text { Velocity from Nuclear } \\
\text { Explosions (U)", V. E. } \\
\text { Wheeler, UOPBA 73-44, } \\
3 / 16 / 73, \text {. CFRD report } \\
\text { "Summary of Free Field } \\
\text { Ground Motion } \\
\text { Measurements (U)", V. E. } \\
\text { Wheeler/ R. G. Preston, } \\
\text { UOPBA 74-126, 8/21/74, }\end{array}$ & & $\begin{array}{l}\text { Surface, Hor. } \\
\text { dist. (NI) (Ref. } \\
\text { UOPBA 73-44); } \\
\text { Subsurface, } 4 \\
\text { GM gages (Ref. } \\
\text { UOPBA 74-126) } \\
\end{array}$ \\
\hline
\end{tabular}


Ground Motion Data: Appendix 3B (John Rambo)

\begin{tabular}{|c|c|c|c|c|c|c|c|c|c|c|}
\hline 更 & HOLE & COMMENTS & (1) & $\begin{array}{c}\text { DATA } \\
\begin{array}{c}\text { Later EG\&G } \\
\text { processed data and } \\
\text { reports }\end{array} \\
\end{array}$ & \begin{tabular}{|c|} 
DATA \\
Later data \\
processed at LLNL \\
by EG\&G
\end{tabular} & \begin{tabular}{|c|} 
DATA \\
Data Plots, \\
Surface, \\
Subsurface \\
Ground Motion, \\
Pressure/ \\
Radiation \\
LOS/Displ./ Misc. \\
Similar Items are \\
included in this \\
column.
\end{tabular} & \begin{tabular}{|c|} 
DATA \\
Ground Motion at \\
Distance From \\
SGZ. Geophone \\
plots (yellow).
\end{tabular} & 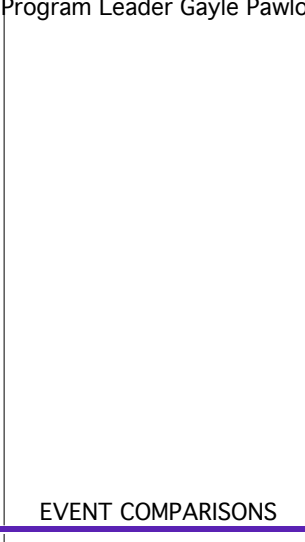 & $\begin{array}{c}\text { SUMMARY AND FINAL } \\
\text { REPORTS } \\
\text { CONF=Classified CFRD } \\
\text { CDR=Containment Data } \\
\text { Report }\end{array}$ & $\begin{array}{c}\text { gski@llnl.gov). } \\
\text { GAGE } \\
\text { LOCATIONS FOR } \\
\text { FREE SURFACE } \\
\text { AND FREE FIELD } \\
\text { DATA } \\
\text { RR=Round Robin } \\
\text { Surface gages } \\
\text { RTP=Recording } \\
\text { Trailer Park } \\
\text { ONI=Orientaion } \\
\text { to WP Not } \\
\text { Investigated }\end{array}$ \\
\hline HAZEBROOK & U10bh & LLNL & None & $\begin{array}{l}\text { CD of Compressed } \\
\text { Raw \& Processed } \\
\text { Data ; CD of ASCII } \\
\text { Processed Data ; } 1 \\
\text { Binder }\end{array}$ & 2 Folders & $\begin{array}{l}2 \text { Pres./ Radiation } \\
\text { Printout Rolls } \\
\text { (Red) }\end{array}$ & & $\begin{array}{l}\text { Binder W, Binder U (Peak } \\
\text { Accelleration of Trailers), } \\
\text { Binder T (CLIPER/EXCOR), } \\
6 \text { Presentation Binders } \\
\end{array}$ & UCRL-ID-119551 (CDR) & $\begin{array}{l}\text { Dist. 50' (Ref. } \\
\text { CDR): } \\
\text { Subsurface, No } \\
\text { free field gages, } \\
1 \text { GM gage in } \\
\text { Plug (Ref. CDR) }\end{array}$ \\
\hline HERMOSA & U7bs & LANL & None & $\begin{array}{l}\text { CD of Compressed } \\
\text { Raw \& Processed } \\
\text { Data }\end{array}$ & None & None & $\begin{array}{l}\text { with interaction } \\
\text { measurment } \\
\text { made at MARIBO, } \\
\text { VILLE, and } \\
\text { COTTAGE. }\end{array}$ & None & None & \\
\hline HOGNOSE & U3ai & $\begin{array}{l}\text { LANL, Pre- } \\
\text { BANEBERRY } \\
\end{array}$ & None & None & None & None & None & $\begin{array}{l}\text { Velocity from Nuclear } \\
\text { Explosions (U)", V. E. } \\
\text { Wheeler, UOPBA 73-44, } \\
3 / 16 / 73, \text {. CFRD report } \\
\text { "Summary of Free Field } \\
\text { Ground Motion } \\
\text { Measurements (U)", V. E. } \\
\text { Wheeler/ R. G. Preston, } \\
\text { UOPBA 74-126, 8/21/74, } \\
\text {. }\end{array}$ & None & $\begin{array}{l}\text { Surface, Hor. } \\
\text { dist. (NI) (Ref. } \\
\text { UOPBA 73-44); } \\
\text { subsurface } 8 \text { GM } \\
\text { gages (ONI) } \\
\text { (Ref. UOPBA 74- } \\
\text { 126) } \\
\text { Uulu, }\end{array}$ \\
\hline HORNITOS & U2Obc & LLNL & 1 Binder & $\begin{array}{l}\text { CD of Compressed } \\
\text { Raw \& Processed } \\
\text { Data; CD of ASCII } \\
\text { Processed Data; } 1 \\
\text { Binder }\end{array}$ & 2 Folders & None & None & Binder T (CLIPER/EXCOR) & UCRL-MI-103510 (CDR) & $\begin{array}{l}\text { Dist. 50', 925', } \\
\text { 1850' (Ref. } \\
\text { CDR): } \\
\text { Subsurface, No } \\
\text { free field gages, } \\
\text { No GM gages in } \\
\text { Plugs (Ref. CDR) } \\
\text { Jullaue, IIUIL. }\end{array}$ \\
\hline HOYA & U2Obe & LLNL & None & $\begin{array}{l}\text { CD of ASCII } \\
\text { Processed Data; } 1 \\
\text { Binder }\end{array}$ & 2 Folders & None & None & None & $\begin{array}{l}\text { "HOYA U2Obe - Special } \\
\text { Measurements } \\
\text { Instrumentation } \\
\text { Performance Summary", } \\
\text { SM-1 101, S. Pratuch ; } \\
\text { UCRL-MI-110331 (CDR) } \\
\end{array}$ & $\begin{array}{l}\text { Dist. 50', RTP } \\
\text { (Ref. CDR): } \\
\text { Subsurface, No } \\
\text { free field gages, } \\
\text { No GM gages in } \\
\text { Plugs (Ref. CDR) } \\
\end{array}$ \\
\hline
\end{tabular}


Ground Motion Data: Appendix 3B (John Rambo)

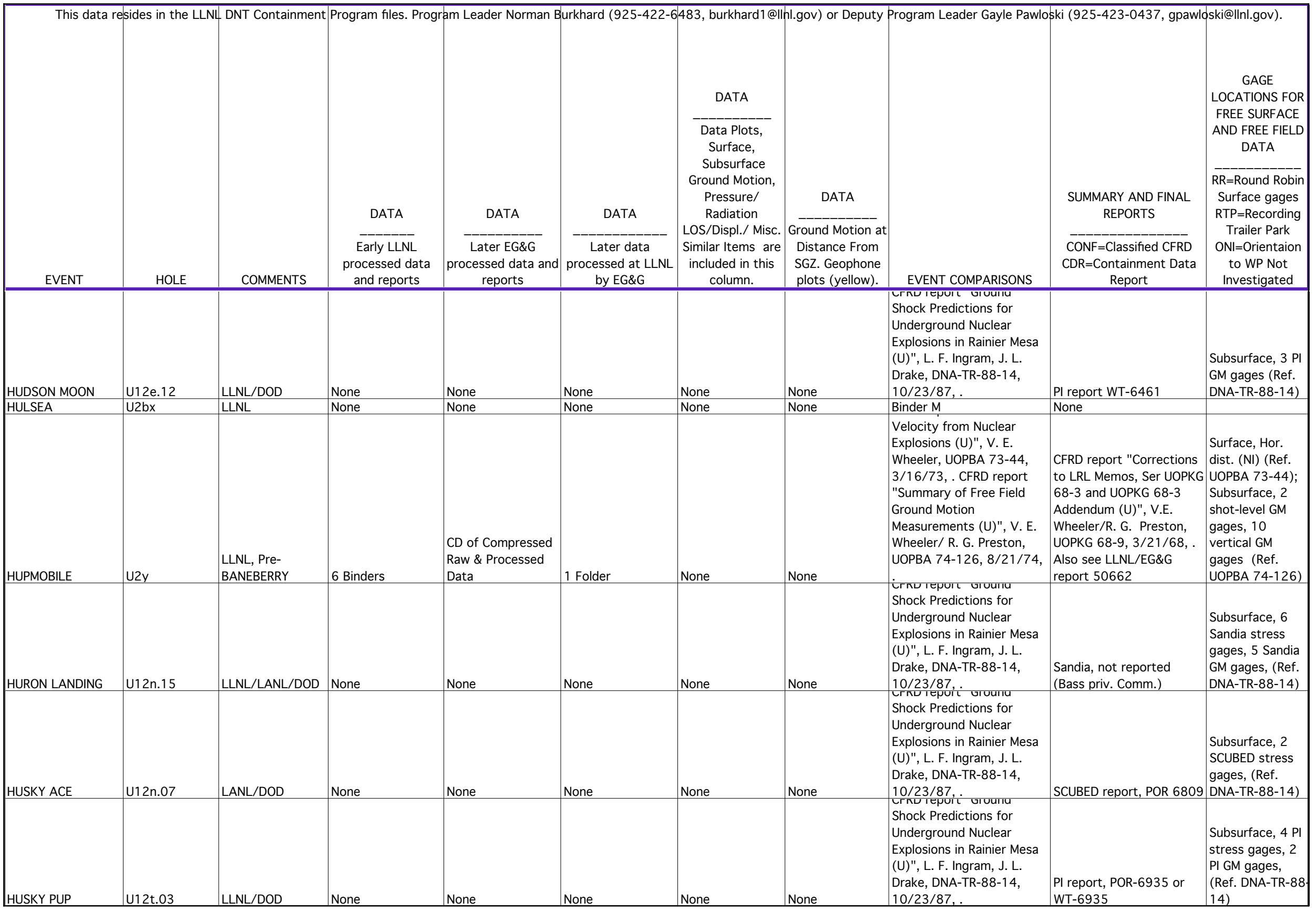


Ground Motion Data: Appendix 3B (John Rambo)

\begin{tabular}{|c|c|c|c|c|c|c|c|c|c|c|}
\hline 更 & HOLE & COMMENTS & $\begin{array}{c}\text { DATA } \\
\text { Early LLNL } \\
\text { processed data } \\
\text { and reports } \\
\end{array}$ & $\begin{array}{c}\text { DATA } \\
\begin{array}{c}\text { Later EG\&G } \\
\text { processed data and } \\
\text { reports }\end{array}\end{array}$ & $\begin{array}{c}\text { DATA } \\
-\begin{array}{c}\text { Later data } \\
\text { processed at LLNL } \\
\text { by EG\&G }\end{array}\end{array}$ & \begin{tabular}{|c|} 
DATA \\
Data Plots, \\
Surface, \\
Subsurface \\
Ground Motion, \\
Pressure/ \\
Radiation \\
LOS/Displ./ Misc. \\
Similar Items are \\
included in this \\
column.
\end{tabular} & $\begin{array}{c}\text { DATA } \\
\text { Ground Motion at } \\
\text { Distance From } \\
\text { SGZ. Geophone } \\
\text { plots (yellow). }\end{array}$ & EVENT COMPARISONS & $\begin{array}{c}\text { SUMMARY AND FINAL } \\
\text { REPORTS } \\
\text { CONF=Classified CFRD } \\
\text { CDR=Containment Data } \\
\text { Report }\end{array}$ & $\begin{array}{c}\text { oski@llnl.gov). } \\
\text { GAGE } \\
\text { LOCATIONS FOR } \\
\text { FREE SURFACE } \\
\text { AND FREE FIELD } \\
\text { DATA } \\
\text { RR=Round Robin } \\
\text { Surface gages } \\
\text { RTP=Recording } \\
\text { Trailer Park } \\
\text { ONI=Orientaion } \\
\text { to WP Not } \\
\text { Investigated }\end{array}$ \\
\hline HUTCH & U2df & $\begin{array}{l}\text { LLNL, Pre- } \\
\text { BANEBERRY, } 1 \\
\text { free field gage in } \\
\text { tuff below water } \\
\text { table } \\
\end{array}$ & 8 Binders & $\begin{array}{l}\text { CD of Compressed } \\
\text { Raw \& Processed } \\
\text { Data; } 1 \text { Small } \\
\text { Binder of } \\
\text { Reprocessed Data } \\
\end{array}$ & 1 Folder & None & \begin{tabular}{|l|} 
"Soil Strain Near \\
a Nuclear \\
Detonation" \\
(UCRL 72391) ; \\
Pathfinder II \\
\end{tabular} & 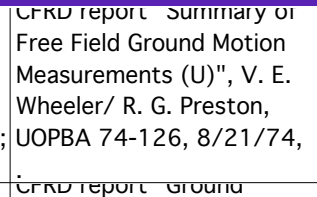 & $\begin{array}{l}\text { "Soil Strain Near a Nuclear } \\
\text { Detonation" BSSA Vol. } \\
60, \text { No.6, pp1999-2014, } \\
\text { 12/1970. Sandia/LLNL, } \\
\text { unreported }\end{array}$ & $\begin{array}{l}\text { Subsurface, } 4 \\
\text { offset vertical } \\
\text { GM gages (Ref. } \\
\text { UOPBA 74-126) }\end{array}$ \\
\hline HYBLA FAIR & U12n.09 & LLNL/DOD & None & None & None & None & None & $\begin{array}{l}\text { Shock Predictions for } \\
\text { Underground Nuclear } \\
\text { Explosions in Rainier Mesa } \\
\text { (U)", L. F. Ingram, J. L. } \\
\text { Drake, DNA-TR-88-14, } \\
\text { 10/23/87, . }\end{array}$ & $\begin{array}{l}\text { SCUBED report, POR } \\
6844 \text {, Sandia report } \\
\text { SAND78-0654 }\end{array}$ & $\begin{array}{l}\text { Subsurface, } 2 \\
\text { SCUBED stress } \\
\text { gages, } 4 \text { Sandia } \\
\text { stress gages. } \\
\text { (Ref. DNA-TR-88- } \\
\text { 14) }\end{array}$ \\
\hline HYBLA GOLD & U12e.20 & LANL/DOD & None & None & None & None & $\begin{array}{l}\text { Earth Strain Cals. } \\
\text { (Yellow) }\end{array}$ & None & None & \\
\hline ICEBERG & U $4 \mathrm{~g}$ & LANL & None & None & None & None & Earth Strain Cals. & None & None & \\
\hline ILDRIM & U2au & $\begin{array}{l}\text { LLNL, Pre- } \\
\text { BANEBERRY } \\
\end{array}$ & 1 Binder & $\begin{array}{l}\text { CD of Compressed } \\
\text { Raw \& Processed } \\
\text { Data }\end{array}$ & None & None & None & None & None & \\
\hline INGOT & U2gg & LLNL & None & \begin{tabular}{|l|} 
CD of Compressed \\
Raw \& Processed \\
Data; CD of ASCII \\
Processed Data; 1 \\
Binder
\end{tabular} & 2 Folders & None & None & Binder V & MISC-8404 (CDR) & $\begin{array}{l}\text { Dist. 50', 910', } \\
800 ', \text { RTP (Ref. } \\
\text { CDR): } \\
\text { Subsurface, No } \\
\text { free field gages, } \\
1 \text { GM gage in } \\
\text { Plug (Ref. CDR) }\end{array}$ \\
\hline INLET & U19f & LANL & None & None & None & None & Earth Strain Cals. & None & None & \\
\hline ISLAY & U2er & LLNL & None & \begin{tabular}{|l|} 
CD of Compressed \\
Raw \& Processed \\
Data; CD of ASCII \\
Processed Data; 1 \\
Binder
\end{tabular} & 1 Folder & $\begin{array}{l}4 \text { Ground Motion } \\
\text { Rolls (Blue) }\end{array}$ & None & $\begin{array}{l}\text { Binder U (Peak } \\
\text { Accelleration of Trailers) }\end{array}$ & $\begin{array}{l}\text { "Motion Measured on the } \\
\text { Emplacement Pipe and } \\
\text { Stemming Plugs, ISLAY } \\
\text { Event" UOPKL 82-72 , } \\
\text { UCRL-ID-127718 (CDR) } \\
\end{array}$ & $\begin{array}{l}\text { Dist. 50', RTP } \\
\text { (1083') (Ref. } \\
\text { CDR): } \\
\text { Subsurface, No } \\
\text { free field gages, } \\
4 \text { GM gages in } \\
\text { Plugs (Ref. CDR) }\end{array}$ \\
\hline
\end{tabular}


Ground Motion Data: Appendix 3B (John Rambo)

\begin{tabular}{|c|c|c|c|c|c|c|c|c|c|c|}
\hline EVENT & HOLE & COMMENTS & $\begin{array}{c}\text { DATA } \\
\text { Early LLNL } \\
\text { processed data } \\
\text { and reports }\end{array}$ & $\begin{array}{c}\text { DATA } \\
\begin{array}{c}\text { Later EG\&G } \\
\text { processed data and } \\
\text { reports }\end{array}\end{array}$ & $\begin{array}{c}\text { DATA } \\
\begin{array}{c}\text { Later data } \\
\text { processed at LLNL } \\
\text { by EG\&G }\end{array}\end{array}$ & \begin{tabular}{|c|} 
DATA \\
Data Plots, \\
Surface, \\
Subsurface \\
Ground Motion, \\
Pressure/ \\
Radiation \\
LOS/Displ./ Misc. \\
Similar Items are \\
included in this \\
column.
\end{tabular} & $\begin{array}{c}\text { DATA } \\
\text { Ground Motion at } \\
\text { Distance From } \\
\text { SGZ. Geophone } \\
\text { plots (yellow). }\end{array}$ & EVENT COMPARISONS & $\begin{array}{c}\text { SUMMARY AND FINAL } \\
\text { REPORTS } \\
\text { CONF=Classified CFRD } \\
\text { CDR=Containment Data } \\
\text { Report }\end{array}$ & $\begin{array}{c}\text { GAGE } \\
\text { LOCATIONS FOR } \\
\text { FREE SURFACE } \\
\text { AND FREE FIELD } \\
\text { DATA } \\
\text { RR=Round Robin } \\
\text { Surface gages } \\
\text { RTP=Recording } \\
\text { Trailer Park } \\
\text { ONl=Orientaion } \\
\text { to WP Not } \\
\text { Investigated }\end{array}$ \\
\hline JARLSBERG & U10ca & LLNL & None & $\begin{array}{l}\text { CD of Compressed } \\
\text { Raw \& Processed } \\
\text { Data; CD of ASCII } \\
\text { Processed Data; } 2 \\
\text { Binders }\end{array}$ & 2 Folders & None & None & 1 Presentation Binder & UCRL-ID-119561 (CDR) & \begin{tabular}{|l} 
Surface, Horiz. \\
Dist. 33.1', \\
968', 363', \\
$207 ', 593 ', 555^{\prime}$ \\
(Ref. CDR): \\
Subsurface, Free \\
field gages, 7 \\
vertical offset \\
GM gages, 6 \\
vertical offset \\
stress gages, 2 \\
GM gages in \\
Plugs (Ref. CDR) \\
Sumbce,
\end{tabular} \\
\hline JEFFERSON & U20ai & LLNL & 1 Binder & $\begin{array}{l}\text { CD of Compressed } \\
\text { Raw \& Processed } \\
\text { Data; CD of ASCII } \\
\text { Processed Data; } 1 \\
\text { Binder }\end{array}$ & 1 Folder & $\begin{array}{l}2 \text { Rolls of Pres. } \\
\text { and Radiation in } \\
\text { Box }\end{array}$ & None & $\begin{array}{l}\text { Binder W, Binder U (Peak } \\
\text { Accelleration of Trailers), } \\
\text { Binder T (CLIPER/EXCOR), } \\
3 \text { Presentation Binders } \\
\end{array}$ & UCRL-ID-1 19478 (CDR) & $\begin{array}{l}\text { Dist. 50' (Ref. } \\
\text { CDR): } \\
\text { Subsurface, No } \\
\text { free field gages, } \\
4 \text { GM gages in } \\
\text { Plugs (Ref. CDR) } \\
\end{array}$ \\
\hline JORUM & U20e & $\begin{array}{l}\text { LLNL, Pre- } \\
\text { BANEBERRY }\end{array}$ & 1 Binder & $\begin{array}{l}\text { Raw \& Processed } \\
\text { Data }\end{array}$ & None & None & $\begin{array}{l}14 \text { Geophone } \\
\text { Rolls (Yellow) }\end{array}$ & $\begin{array}{l}\text { Binder Q, } 1 \text { Presentation } \\
\text { Binder }\end{array}$ & None & \\
\hline KANKAKEE & U10p & $\begin{array}{l}\text { LLNL, Pre- } \\
\text { BANEBERRY }\end{array}$ & None & None & None & None & $\begin{array}{l}1 \text { Geophone Roll } \\
\text { (Yellow) }\end{array}$ & None & None & \\
\hline KAPPELI & U20am & LLNL & None & None & None & None & $\begin{array}{l}\text { None } \\
\text { Lutvr Itpuाt }\end{array}$ & $\begin{array}{l}\text { Binder T (CLIPER/EXCOR), } \\
1 \text { Presentation Binder }\end{array}$ & None & \\
\hline KARA & U2dh 3 & LLNL & None & None & None & None & $\begin{array}{l}\text { "Round Robin } \\
\text { Program KARA } \\
\text { Event (U)", W. R. } \\
\text { Perret, Sandia } \\
\text { UOPBA 72-61, } \\
\text { 5/26/72 (V). } \\
\end{array}$ & $\begin{array}{l}\text { CFRD report "Peak Surface } \\
\text { Velocity from Nuclear } \\
\text { Explosions (U)", V. E. } \\
\text { Wheeler, UOPBA 73-44, } \\
3 / 16 / 73,\end{array}$ & None & $\begin{array}{l}\text { Surface (Ref. } \\
\text { RR) Horiz., 45', } \\
425^{\prime}, 425^{\prime}, 425^{\prime}\end{array}$ \\
\hline
\end{tabular}


Ground Motion Data: Appendix 3B (John Rambo)

\begin{tabular}{|c|c|c|c|c|c|c|c|c|c|c|}
\hline 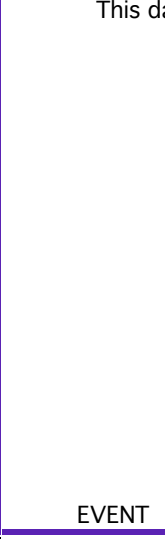 & HOLE & COMMENTS & (1) & $\begin{array}{c}\text { DATA } \\
\begin{array}{c}\text { Later EG\&G } \\
\text { processed data and } \\
\text { reports }\end{array}\end{array}$ & $\begin{array}{c}\text { DATA } \\
-2 \text { Later data } \\
\text { processed at LLNL } \\
\text { by EG\&G }\end{array}$ & \begin{tabular}{|c} 
DATA \\
Data Plots, \\
Surface, \\
Subsurface \\
Ground Motion, \\
Pressure/ \\
Radiation \\
LOS/Displ./ Misc. \\
Similar Items are \\
included in this \\
column. \\
\end{tabular} & \begin{tabular}{|c|} 
DATA \\
Ground Motion at \\
Distance From \\
SGZ. Geophone \\
plots (yellow).
\end{tabular} & 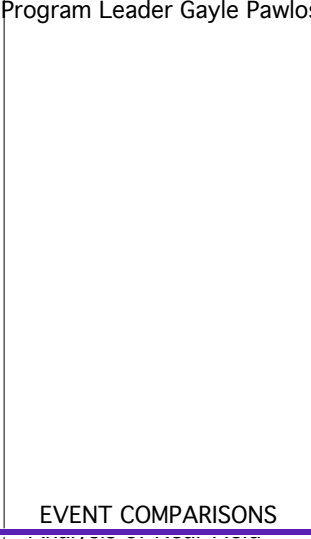 & 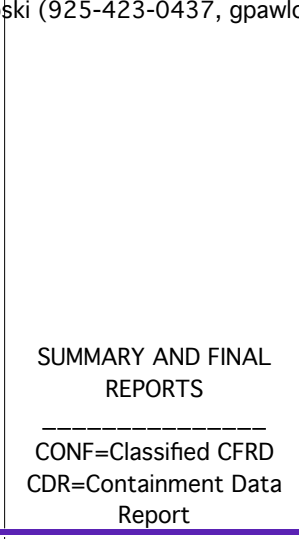 & $\begin{array}{c}\text { oski@llnl.gov). } \\
\text { GAGE } \\
\text { LOCATIONS FOR } \\
\text { FREE SURFACE } \\
\text { AND FREE FIELD } \\
\text { DATA } \\
\text { RR=Round Robin } \\
\text { Surface gages } \\
\text { RTP=Recording } \\
\text { Trailer Park } \\
\text { ONI=Orientaion } \\
\text { to WP Not } \\
\text { Investigated } \\
\end{array}$ \\
\hline KARAB & U4ah & LLNL & None & $\begin{array}{l}\text { CD of Compressed } \\
\text { Raw \& Processed } \\
\text { Data; CD of ASCII } \\
\text { Processed Data; } 1 \\
\text { Binder }\end{array}$ & 1 Folder & None & \begin{tabular}{|l|} 
\\
\\
Earth Strain Cals. \\
\end{tabular} & $\begin{array}{l}\text { Ground Motion from } \\
\text { Nuclear Detonations in } \\
\text { High Porosity Media, R. T. } \\
\text { Terhune, M. Heusinkveld, } \\
\text { Proceedings of the Second } \\
\text { Symposium of } \\
\text { Underground Nuclear } \\
\text { Explosions, Albuquerque } \\
\text { NM, 8/2-4/83, Vol2 }\end{array}$ & $\begin{array}{l}\text { "Free-Field Ground Motion } \\
\text { from the Underground } \\
\text { Nuclear Explosion KARAB" } \\
\text { UCID-18608 (Conf. FRD); } \\
\text { "Post Operational Report } \\
\text { for the Containment } \\
\text { Diagnostics on KARAB, } \\
\text { U4ah" (Conf.) ; UCRL-ID- } \\
\text { 131648 (CDR) }\end{array}$ & $\begin{array}{l}\text { Subsurface, free } \\
\text { field, see report }\end{array}$ \\
\hline KASH & U20af & LLNL & None & $\begin{array}{l}\text { Raw \& Processed } \\
\text { Data }\end{array}$ & 1 Folder & None & Earth Strain Cals. & $\begin{array}{l}\text { None } \\
\text { Domuets }\end{array}$ & None & \\
\hline KASHAN & U10av & LLNL & 6 Binders & $\begin{array}{l}\text { CD of Compressed } \\
\text { Raw \& Processed } \\
\text { Data }\end{array}$ & 1 Folder & None & \begin{tabular}{|l|} 
\\
Round Robin, \\
PDS Cals. \\
\end{tabular} & $\begin{array}{l}\text { report "Summary of Free } \\
\text { Field Ground Motion } \\
\text { Measurements (U)", V. E. } \\
\text { Wheeler/ R. G. Preston, } \\
\text { UOPBA 74-126, 8/21/74, } \\
\text {. }\end{array}$ & None & $\begin{array}{l}\text { Subsurface: } \\
\text { stemming GM } \\
\text { (Ref. UOPBA 74- } \\
126)\end{array}$ \\
\hline KASSERI & U2Oz & LLNL & None & None & None & None & $\begin{array}{l}\text { Earth Strain Cals. } \\
\text { PDS Cals. }\end{array}$ & None & None & \\
\hline KAWICH & $\mathrm{U} 2 \mathrm{cu}$ & LLNL & None & $\begin{array}{l}\text { CD of Compressed } \\
\text { Raw \& Processed } \\
\text { Data; CD of ASCII } \\
\text { Processed Data; } 1 \\
\text { Binder }\end{array}$ & 1 Folder & $\begin{array}{l}1 \text { Ground Motion } \\
\text { Roll (Blue) } \\
\text { NOTE: Label says } \\
\text { KAWICH. Should } \\
\text { verify that it is } \\
\text { not KAWICH-A. } \\
\end{array}$ & None & $\begin{array}{l}\text { Binder V, Binder T } \\
\text { (CLIPER/EXCOR), } 1 \\
\text { Presentation Binder }\end{array}$ & MISC. 4803 (CDR) & $\begin{array}{l}\text { Dist. 50', 632' } \\
\text { (Ref. CDR): } \\
\text { Subsurface, No } \\
\text { free field gages, } \\
5 \text { GM gages in } \\
\text { Plugs (Ref. CDR) }\end{array}$ \\
\hline KAWICH-A & U8n & LLNL & None & $\begin{array}{l}\text { CD of Compressed } \\
\text { Raw \& Processed } \\
\text { Data; CD of ASCII } \\
\text { Processed Data; } 1 \\
\text { Binder }\end{array}$ & 1 Folder & None & None & Binder W & UCRL-ID-120477 (CDR) & $\begin{array}{l}\text { Dist. RTP only, } \\
\text { no other usable } \\
\text { data (Ref. CDR): } \\
\text { Subsurface, No } \\
\text { free field gages, } \\
\text { No GM gages in } \\
\text { Plugs (Ref. CDR) } \\
\end{array}$ \\
\hline
\end{tabular}


Ground Motion Data: Appendix 3B (John Rambo)

\begin{tabular}{|c|c|c|c|c|c|c|c|c|c|c|}
\hline This c & ides in the & DNT Containme & $\begin{array}{l}\text { DATA } \\
\text { Early LLNL } \\
\text { processed data } \\
\text { and reports }\end{array}$ & $\begin{array}{c}\text { DATA } \\
\begin{array}{c}\text { Later EG\&G } \\
\text { processed data and } \\
\text { reports }\end{array}\end{array}$ & $\begin{array}{c}\text { DATA } \\
- \text { Later data } \\
\begin{array}{c}\text { processed at LLNL } \\
\text { by EG\&G }\end{array}\end{array}$ & \begin{tabular}{|c}
483, burkhard1@ @lli \\
DATA \\
Data Plots, \\
Surface, \\
Subsurface \\
Ground Motion, \\
Pressure/ \\
Radiation \\
LOS/Displ./ Misc. \\
Similar Items are \\
included in this \\
column.
\end{tabular} & \begin{tabular}{|c|} 
DATA \\
Ground Motion at \\
Distance From \\
SGZ. Geophone \\
plots (yellow).
\end{tabular} & Program Leader Gayle Pa & $\begin{array}{c}\text { SUMMARY AND FINAL } \\
\text { REPORTS } \\
\text { CONF=Classified CFRD } \\
\text { CDR=Containment Data } \\
\text { Report }\end{array}$ & $\begin{array}{l}\text { ski@llnl.gov). } \\
\text { GAGE } \\
\text { LOCATIONS FOR } \\
\text { FREE SURFACE } \\
\text { AND FREE FIELD } \\
\text { DATA } \\
\text { RR=Round Robin } \\
\text { Surface gages } \\
\text { RTP=Recording } \\
\text { Trailer Park } \\
\text { ONI=Orientaion } \\
\text { to WP Not } \\
\text { Investigated }\end{array}$ \\
\hline KEARSARGE & U19ax & LLNL & None & $\begin{array}{l}\text { CD of Compressed } \\
\text { Raw \& Processed } \\
\text { Data; CD of ASCII } \\
\text { Processed Data; } 1 \\
\text { Binder }\end{array}$ & 1 Folder & None & None & $\begin{array}{l}\text { Binder W, Binder T } \\
\text { (CLIPER/EXCOR) }\end{array}$ & MISC 4718 (CDR) & $\begin{array}{l}\text { Oul ave, nuil<. } \\
\text { Dist. RTP only } \\
\text { (Ref. CDR): } \\
\text { Subsurface, No } \\
\text { free field gages, } \\
\text { No GM gages in } \\
\text { Plugs (Ref. CDR) }\end{array}$ \\
\hline KEELSON & U7ai & LANL & None & None & None & None & Earth Strain Cals. & None & None & \\
\hline KERNVILLE & U20ar & LLNL & None & $\begin{array}{l}\text { CD of Compressed } \\
\text { Raw \& Processed } \\
\text { Data; CD of ASCII } \\
\text { Processed Data ; } 1 \\
\text { Binder }\end{array}$ & 1 Folder & None & None & $\begin{array}{l}\text { Binder U (Peak } \\
\text { Accelleration of Trailers) }\end{array}$ & UCRL-ID-119479 (CDR) & $\begin{array}{l}\text { Dist. 50', RTP } \\
\text { (886') (Ref. } \\
\text { CDR): } \\
\text { Subsurface, No } \\
\text { free field gages, } \\
\text { No GM gages in } \\
\text { Plugs (Ref. CDR) }\end{array}$ \\
\hline KESTI & U9cn & LLNL & None & $\begin{array}{l}\text { CD of Compressed } \\
\text { Raw \& Processed } \\
\text { Data; CD of ASCII } \\
\text { Processed Data; } 1 \\
\text { Binder } \\
\end{array}$ & 1 Folder & None & None & Binder T (CLIPER/EXCOR) & $\begin{array}{l}\text { Draft Report "Strong } \\
\text { Motion From the KESTI } \\
\text { Event" ; UCRL-ID-125017 } \\
(C D R)\end{array}$ & $\begin{array}{l}\text { Dist. 50' (Ref. } \\
\text { CDR): } \\
\text { Subsurface, No } \\
\text { free field gages, } \\
4 \text { GM gages in } \\
\text { Plugs (Ref. CDR) } \\
\end{array}$ \\
\hline
\end{tabular}


Ground Motion Data: Appendix 3B (John Rambo)

\begin{tabular}{|c|c|c|c|c|c|c|c|c|c|c|}
\hline 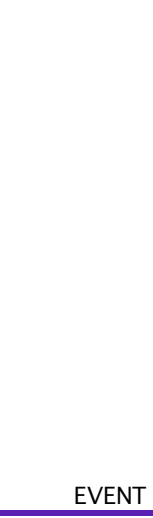 & HOLE & COMMENTS & $\begin{array}{c}\text { DATA } \\
\text { Early LLNL } \\
\text { processed data } \\
\text { and reports }\end{array}$ & $\begin{array}{c}\text { DATA } \\
\begin{array}{c}\text { Later EG\&G } \\
\text { processed data and } \\
\text { reports }\end{array} \\
\end{array}$ & $\begin{array}{c}\text { DATA } \\
-\begin{array}{c}\text { Later data } \\
\text { processed at LLNL } \\
\text { by EG\&G }\end{array}\end{array}$ & \begin{tabular}{|c|} 
\\
DATA \\
Data Plots, \\
Surface, \\
Subsurface \\
Ground Motion, \\
Pressure/ \\
Radiation \\
LOS/Displ./ Misc. \\
Similar Items are \\
included in this \\
column.
\end{tabular} & $\begin{array}{l}\text { DATA } \\
\text { Ground Motion at } \\
\text { Distance From } \\
\text { SGZ. Geophone } \\
\text { plots (yellow). }\end{array}$ & EVENT COMPARISONS & $\begin{array}{c}\text { SUMMARY AND FINAL } \\
\text { REPORTS } \\
\text { CONF=Classified CFRD } \\
\text { CDR=Containment Data } \\
\text { Report }\end{array}$ & \begin{tabular}{|c|}
\multicolumn{1}{|c}{} \\
GAGE \\
LOCATIONS FOR \\
FREE SURFACE \\
AND FREE FIELD \\
DATA \\
RR=Round Robin \\
Surface gages \\
RTP=Recording \\
Trailer Park \\
ONI=Orientaion \\
to WP Not \\
Investigated
\end{tabular} \\
\hline KNOX & U2at & $\begin{array}{l}\text { LLNL, Pre- } \\
\text { BANEBERRY, } 2 \\
\text { free field gages in } \\
\text { tuff below the } \\
\text { water table, } 1 \\
\text { gage in carbonate }\end{array}$ & 2 Binders & 要 & None & None & Pathfinder I & \begin{tabular}{|l} 
"Peak Surface Velocity \\
from Nuclear Explosions \\
(U)", V. E. Wheeler, UOPBA \\
73-44, 3/16/73, . CFRD \\
report "Summary of Free \\
Field Ground Motion \\
Measurements (U)", V. E. \\
Wheeler/ R. G. Preston, \\
UOPBA 74-126, 8/21/74, \\
. CFRD report "Ground \\
Shock Predictions for \\
Underground Nuclear \\
Explosions in Rainier Mesa \\
(U)", L. F. Ingram, J. L. \\
Drake, DNA-TR-88-14, \\
$10 / 23 / 87$. Unclassified \\
report "Free-Field Ground \\
Motion Induced by \\
Underground Explosions", \\
W. R. Perret, and R. C. \\
Bass, SAND74-0252, \\
Sandia Laboratories, \\
$11 / 72$.
\end{tabular} & \begin{tabular}{|l} 
\\
Sandia, unreported
\end{tabular} & $\begin{array}{l}\text { Surface, Hor. } \\
\text { dist. (NI) (Ref. } \\
\text { UOPBA 73-44); } \\
\text { Subsurface, } 5 \\
\text { GM gages (ONI) } \\
\text { (Ref. UOPBA 74- } \\
126)\end{array}$ \\
\hline KRYDDOST & U2co & LLNL & None & $\begin{array}{l} \\
\text { CD of Compressed } \\
\text { Raw \& Processed } \\
\text { Data ; CD of ASCII } \\
\text { Processed Data ; } 1 \\
\text { Binder }\end{array}$ & $\begin{array}{l}\text { CFRD report } \\
\text { "Instrumentation of } \\
\text { UE2co for the } \\
\text { KRYDDOST Event", } \\
\text { V. E. Wheeler/T. F. } \\
\text { Stubbs, UOPKL } 82- \\
10,1 / 25 / 82, .2 \\
\text { Folders } \\
\end{array}$ & \begin{tabular}{|l|}
1 Ground Motion \\
Roll (Blue)
\end{tabular} & None & $\begin{array}{l}\text { Binder T (CLIPER/EXCOR), } \\
1 \text { Presentation Binder }\end{array}$ & $\begin{array}{l}\text { Draft Report "KRYDDOST: } \\
\text { Ground Motion Data } \\
\text { Report"; "Containment } \\
\text { Analysis for KRYDDOST } \\
\text { Nuclear Event" UCRL } \\
53331 \text { (Conf.) ; UCRL-ID- } \\
121261 \text { (CDR) } \\
\end{array}$ & $\begin{array}{l}\text { Surface, Horiz. } \\
\text { Dist. 50', (540', } \\
540^{\prime}, 540^{\prime} \\
\text { different } \\
\text { azmuths) (Ref. } \\
\text { CDR): } \\
\text { Subsurface, Free } \\
\text { field gages, } 5 \\
\text { vertical offset } \\
\text { GM gages, } 3 \text { GM } \\
\text { gages in Plugs } \\
\text { (Ref. CDR) } \\
\end{array}$ \\
\hline $\begin{array}{l}\text { KYACK } 2 \\
\text { KYACK A }\end{array}$ & $\begin{array}{l}\text { U2bq } 2 \text { U2bq } \\
1\end{array}$ & $\begin{array}{l}\text { LLNL, Pre- } \\
\text { BANEBERRY }\end{array}$ & 2 Binders & $\begin{array}{l}\text { CD of Compressed } \\
\text { Raw \& Processed } \\
\text { Data }\end{array}$ & 1 Folder & None & None & Binder D & None & \\
\hline
\end{tabular}


Ground Motion Data: Appendix 3B (John Rambo)

\begin{tabular}{|c|c|c|c|c|c|c|c|c|c|c|}
\hline This o & HOLE & DI Containme & $\begin{array}{c}\text { DATA } \\
\text { Early LLNL } \\
\text { processed data } \\
\text { and reports } \\
\end{array}$ & $\begin{array}{c}\text { DATA } \\
\text { Later EG\&G } \\
\begin{array}{c}\text { processed data and } \\
\text { reports }\end{array} \\
\end{array}$ & \begin{tabular}{|c|} 
DATA \\
Later data \\
processed at LLNL \\
by EG\&G
\end{tabular} & \begin{tabular}{|c|} 
DATA \\
Data Plots, \\
Surface, \\
Subsurface \\
Ground Motion, \\
Pressure/ \\
Radiation \\
LOS/Displ./ Misc. \\
Similar Items are \\
included in this \\
column. \\
\end{tabular} & $\mid$\begin{tabular}{c|} 
DATA \\
Ground Motion at \\
Distance From \\
SGZ. Geophone \\
plots (yellow).
\end{tabular} & 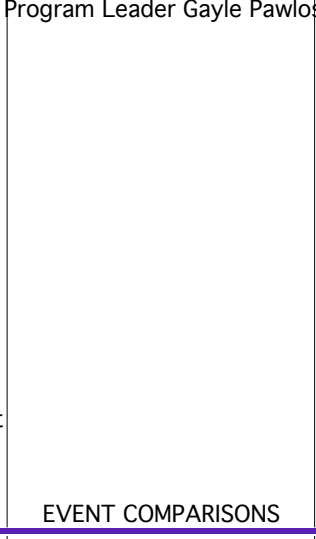 & $\begin{array}{c}\text { SUMMARY AND FINAL } \\
\text { REPORTS } \\
\text { CONF=Classified CFRD } \\
\text { CDR=Containment Data } \\
\text { Report }\end{array}$ & $\begin{array}{l}\text { Gsi@llnl.gov). } \\
\text { GAGE } \\
\text { LOCATIONS FOR } \\
\text { FREE SURFACE } \\
\text { AND FREE FIELD } \\
\text { DATA } \\
\text { RR=Round Robin } \\
\text { Surface gages } \\
\text { RTP=Recording } \\
\text { Trailer Park } \\
\text { ONI=Orientaion } \\
\text { to WP Not } \\
\text { Investigated }\end{array}$ \\
\hline LABAN & U2ff & LLNL & None & $\begin{array}{l}\text { Raw \& Processed } \\
\text { Data; CD of ASCII } \\
\text { Processed Data; } 1 \\
\text { Ground Motion } \\
\text { Binder, } 1 \text { Pressure } \\
\text { and Radiation } \\
\text { Binder, } \\
\end{array}$ & 1 Folder & \begin{tabular}{|l|}
2 Ground Motion \\
Rolls (Blue), 2 \\
Rolls of Pres./ \\
Radiation Traces \\
(Red), 1 Pres./ \\
Radiation Printout \\
(Volts) Roll (Red) \\
\end{tabular} & None & $\begin{array}{l}\text { Binder Y, Binder U (Peak } \\
\text { Accelleration of Trailers), } \\
\text { Binder T (CLIPER/EXCOR), } \\
\text { Binder S (SMIDS Collapse } \\
\text { Signals), } 1 \text { Presentation } \\
\text { Binder }\end{array}$ & $\begin{array}{l}\text { Draft Report "Special } \\
\text { Measurements on the } \\
\text { LABAN Event, U2ff: Data } \\
\text { Report" ; UCRL-ID- } \\
121264 \text { (CDR) }\end{array}$ & $\begin{array}{l}\text { Surface, Horiz. } \\
\text { Dist. 50' (Ref. } \\
\text { CDR): } \\
\text { Subsurface, No } \\
\text { free field gages, } \\
2 \text { GM gages in } \\
\text { Plugs (Ref. CDR) }\end{array}$ \\
\hline LABIS & U10an & $\begin{array}{l}\text { LLNL, Pre- } \\
\text { BANEBERRY } \\
\end{array}$ & None & None & None & $\begin{array}{l}\text { None } \\
\text { Non IIVUIIU IVIULIUII }\end{array}$ & $\begin{array}{l}1 \text { Wide } \\
\text { Geophone Roll } \\
\text { (Yellow) }\end{array}$ & None & None & \\
\hline LABQUARK & U19an & LLNL & None & $\begin{array}{l}\text { CD of Compressed } \\
\text { Raw \& Processed } \\
\text { Data; CD of ASCII } \\
\text { Processed Data ; } 1 \\
\text { Binder }\end{array}$ & 1 Folder & \begin{tabular}{l|} 
Roll (Blue), \\
1 Pres/ Radiation \\
Printout Roll \\
(Red), 1Roll of \\
Pres/ Radiation \\
Traces (Red) \\
\end{tabular} & None & $\begin{array}{l}\text { Binder W, Binder U (Peak } \\
\text { Accelleration of Trailers), } \\
\text { Binder T (CLIPER/EXCOR), } \\
3 \text { Presentation Binders } \\
\end{array}$ & UCRL-ID-121260 (CDR) & $\begin{array}{l}\text { Dist. 50', RTP } \\
\text { (Ref. CDR): } \\
\text { Subsurface, No } \\
\text { free field gages, } \\
\text { No GM gages in } \\
\text { Plugs (Ref. CDR) }\end{array}$ \\
\hline LAGOON & U10ar & LLNL & 2 Binders & $\begin{array}{l}\text { CD of Compressed } \\
\text { Raw \& Processed } \\
\text { Data }\end{array}$ & 1 Folder & None & $\begin{array}{l}\text { "Round Robin } \\
\text { Program } \\
\text { LAGOON Event } \\
\text { (U)", W. R. } \\
\text { Perret, Sandia } \\
\text { UOPBA \#002, } \\
11 / 5 / 71(\mathrm{~V}) .\end{array}$ & $\begin{array}{l}\text { CFRD report "Peak Surface } \\
\text { Velocity from Nuclear } \\
\text { Explosions (U)", V. E. } \\
\text { Wheeler, UOPBA 73-44, } \\
3 / 16 / 73\end{array}$ & $\begin{array}{l}\text { CONF report "Surface- } \\
\text { Motion Measurements in } \\
\text { BRACKEN and LAGOON } \\
\text { (U)", R. G. Preston and V. } \\
\text { E. Wheeler, UOPBA 72-10, } \\
\text { 2/23/72, . }\end{array}$ & $\begin{array}{l}\text { Surface,Horiz.,2 } \\
\text { 6' 436' 436' } \\
506^{\prime} \text { (Ref. RR) } \\
\text {;Surface, 50', } \\
\text { and 565' (Ref. } \\
\text { UOPBA 72-10). }\end{array}$ \\
\hline LAGUNA & U3fd & LANL & None & None & None & None & \begin{tabular}{|l|} 
report "Round \\
Robin Program \\
LAGUNA Event", \\
W. R. Perret, \\
Sandia, No \\
Reference, \\
7/1/71 (V). \\
\end{tabular} & $\begin{array}{l}\text { CFRD report "Peak Surface } \\
\text { Velocity from Nuclear } \\
\text { Explosions (U)", V. E. } \\
\text { Wheeler, UOPBA 73-44, } \\
3 / 16 / 73 \text {, } \\
\end{array}$ & None & $\begin{array}{l}\text { Surface (Ref. } \\
\text { RR) Horiz., 25', } \\
746^{\prime}\end{array}$ \\
\hline
\end{tabular}


Ground Motion Data: Appendix 3B (John Rambo)

\begin{tabular}{|c|c|c|c|c|c|c|c|c|c|c|}
\hline This $\mathrm{c}$ & Ides in the & - & Program nies. Pros & $\begin{array}{c}\text { DATA } \\
\begin{array}{c}\text { Later EG\&G } \\
\text { processed data and } \\
\text { reports }\end{array} \\
\end{array}$ & $\begin{array}{c}\text { DATA } \\
\text { - Later data } \\
\text { processed at LLNL } \\
\text { by EG\&G }\end{array}$ & \begin{tabular}{|c} 
DATA \\
Data Plots, \\
Surface, \\
Subsurface \\
Ground Motion, \\
Pressure/ \\
Radiation \\
LOS/Displ./ Misc. \\
Similar Items are \\
included in this \\
column.
\end{tabular} & \begin{tabular}{|c|} 
DATA \\
Ground Motion at \\
Distance From \\
SGZ. Geophone \\
plots (yellow).
\end{tabular} & EVENT COMPARISONS & $\begin{array}{c}\text { SUMMARY AND FINAL } \\
\text { REPORTS } \\
\text { CONF=Classified CFRD } \\
\text { CDR=Containment Data } \\
\text { Report }\end{array}$ & $\begin{array}{c}\text { GAGE } \\
\text { LOCATIONS FOR } \\
\text { FREE SURFACE } \\
\text { AND FREE FIELD } \\
\text { DATA } \\
\text { RR=Round Robin } \\
\text { Surface gages } \\
\text { RTP=Recording } \\
\text { Trailer Park } \\
\text { ONI=Orientaion } \\
\text { to WP Not } \\
\text { Investigated }\end{array}$ \\
\hline LAMPHER & U2x & $\begin{array}{l}\text { LLNL, Pre- } \\
\text { BANEBERRY, } 2 \\
\text { gages in tuff } \\
\text { below water } \\
\text { table, } 2 \text { gages in } \\
\text { carbonate rock } \\
\end{array}$ & None & None & None & None & None & $\begin{array}{l}\text { Velocity from Nuclear } \\
\text { Explosions (U)", V. E. } \\
\text { Wheeler, UOPBA 73-44, } \\
3 / 16 / 73, \text {. CFRD report } \\
\text { "Summary of Free Field } \\
\text { Ground Motion } \\
\text { Measurements (U)", V. E. } \\
\text { Wheeler/ R. G. Preston, } \\
\text { UOPBA 74-126, 8/21/74, } \\
\end{array}$ & Sandia, unreported & $\begin{array}{l}\text { Surface, Hor. } \\
\text { dist. (NI) (Ref. } \\
\text { UOPBA 73-44); } \\
\text { Subsurface, } 8 \\
\text { offset vertical } \\
\text { GM gages, } 4 \\
\text { vertical GM } \\
\text { gages (Ref. } \\
\text { UOPBA 74-126) } \\
\end{array}$ \\
\hline LANPHER & $\mathrm{U} 2 \mathrm{x}$ & $\begin{array}{l}\text { LLNL, Pre- } \\
\text { BANEBERRY, } \\
\text { Some free field } \\
\text { gage data from } \\
\text { below the water } \\
\text { table. }\end{array}$ & 2 Binders & $\begin{array}{l}\text { CD of Compressed } \\
\text { Raw \& Processed } \\
\text { Data }\end{array}$ & 1 Folder & None & \begin{tabular}{|l|} 
\\
\\
Pathfinder I ; 1 \\
$\begin{array}{l}\text { Geophone Roll } \\
\text { (Yellow) }\end{array}$ \\
\end{tabular} & $\begin{array}{l}\text { Binders G, R, and CFRD } \\
\text { report "Ground Shock } \\
\text { Predictions for } \\
\text { Underground Nuclear } \\
\text { Explosions in Rainier Mesa } \\
\text { (U)", L. F. Ingram, J. L. } \\
\text { Drake, DNA-TR-88-14, } \\
\text { 10/23/87. Unclassified } \\
\text { report "Free-Field Ground } \\
\text { Motion Induced by } \\
\text { Underground Explosions", } \\
\text { W. R. Perret, and R. C. } \\
\text { Bass, SAND74-0252, } \\
\text { Sandia Laboratories, } \\
\end{array}$ & $\begin{array}{l}\text { CFRD report "Preliminary } \\
\text { Report: Response of the } \\
\text { Pipe in the LANPHER } \\
\text { Event (U)", V. E. Wheeler } \\
\text { and R. G. Preston, UCID- } \\
15292,1 / 15 / 68, .\end{array}$ & $\begin{array}{l}\text { Near surface GM } \\
\text { gages. }\end{array}$ \\
\hline LATIRE & U4d & LANL & None & None & None & None & Earth Strain Cals. & None & None & \\
\hline LIPTAUER & U2eh & LLNL & None & None & None & None & $\begin{array}{l}\text { Pathfinder CD of } \\
\text { Compressed Raw } \\
\text { \& Processed } \\
\text { Data }(\mathrm{V})\end{array}$ & None & None & \\
\hline
\end{tabular}


Ground Motion Data: Appendix 3B (John Rambo)

\begin{tabular}{|c|c|c|c|c|c|c|c|c|c|c|}
\hline (1) & HOLE & COMMENTS & 更 & $\begin{array}{c}\text { DATA } \\
\begin{array}{c}\text { Later EG\&G } \\
\text { processed data and } \\
\text { reports }\end{array}\end{array}$ & $\begin{array}{c}\text { DATA } \\
-\begin{array}{c}\text { Later data } \\
\text { processed at LLNL } \\
\text { by EG\&G }\end{array}\end{array}$ & \begin{tabular}{|c|} 
DATA \\
Data Plots, \\
Surface, \\
Subsurface \\
Ground Motion, \\
Pressure/ \\
Radiation \\
LOS/Displ./ Misc. \\
Similar Items are \\
included in this \\
column. \\
\end{tabular} & \begin{tabular}{|c|} 
\\
DATA \\
Ground Motion at \\
Distance From \\
SGZ. Geophone \\
plots (yellow).
\end{tabular} & 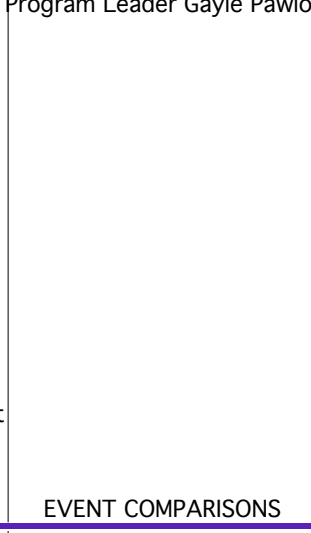 & $\begin{array}{c}\text { SUMMARY AND FINAL } \\
\text { REPORTS } \\
\text { CONF=Classified CFRD } \\
\text { CDR=Containment Data } \\
\text { Report }\end{array}$ & $\begin{array}{c}\text { GSkI@ } \\
\text { GAGII.gov). } \\
\text { LOCATIONS FOR } \\
\text { FREE SURFACE } \\
\text { AND FREE FIELD } \\
\text { DATA } \\
\text { RR=Round Robin } \\
\text { Surface gages } \\
\text { RTP=Recording } \\
\text { Trailer Park } \\
\text { ONI=Orientaion } \\
\text { to WP Not } \\
\text { Investigated }\end{array}$ \\
\hline LOCKNEY & U19aq & LANL & None & 西 & None & None & \begin{tabular}{|l|}
$\mid$ "LOCKNEY \\
(U19aq) \\
Interaction with \\
KERNVILLE \\
(U2Oar) Ground \\
Motion and \\
Structural \\
Response \\
Measurements" \\
UCID 21409 \\
(Motion at \\
KERNVILLE) (CL, \\
CN,3,Ground \\
Motion-Events \\
\end{tabular} & None & None & \\
\hline LONGCHAMPS & U $2 \mathrm{dm}$ & LLNL & None & None & None & None & \begin{tabular}{|l|} 
"Round Robin \\
Program \\
LONGCHAMPS \\
Event (U)", W. R. \\
Perret, Sandia \\
UOPBA 72-49, \\
5/5/72 (V). \\
\end{tabular} & $\begin{array}{l}\text { CFRD report "Peak Surface } \\
\text { Velocity from Nuclear } \\
\text { Explosions (U)", V. E. } \\
\text { Wheeler, UOPBA } 73-44, \\
3 / 16 / 73 \text {, } \\
\end{array}$ & None & $\begin{array}{l}\text { Surface (Ref. } \\
\text { RR) Horiz., 50', } \\
505,505^{\prime}, 505^{\prime}\end{array}$ \\
\hline
\end{tabular}


Ground Motion Data: Appendix 3B (John Rambo)

\begin{tabular}{|c|c|c|c|c|c|c|c|c|c|c|}
\hline This o & des in th & DNT Containment & $\begin{array}{c}\text { DATA } \\
\text { Early LLNL } \\
\text { processed data } \\
\text { and reports }\end{array}$ & $\begin{array}{c}\text { DATA } \\
\begin{array}{c}\text { Later EG\&G } \\
\text { processed data and } \\
\text { reports }\end{array}\end{array}$ & $\begin{array}{c}\text { DATA } \\
\text { - Later data } \\
\text { processed at LLNL } \\
\text { by EG\&G }\end{array}$ & \begin{tabular}{|} 
6483, burkhard1@|| \\
DATA \\
Data Plots, \\
Surface, \\
Subsurface \\
Ground Motion, \\
Pressure/ \\
Radiation \\
LOS/Displ./ Misc. \\
Similar Items are \\
included in this \\
column.
\end{tabular} & $\begin{array}{c}\text { DATA } \\
\text { Ground Motion at } \\
\text { Distance From } \\
\text { SGZ. Geophone } \\
\text { plots (yellow). }\end{array}$ & rogram Leader Gayle Pa & $\begin{array}{l}\text { ski (925-423-0437, gpawl } \\
\text { SUMMARY AND FINAL } \\
\text { REPORTS } \\
\text { CONF=Classified CFRD } \\
\text { CDR=Containment Data } \\
\text { Report }\end{array}$ & $\begin{array}{l}\text { oski@llnl.gov). } \\
\text { GAGE } \\
\text { LOCATIONS FOR } \\
\text { FREE SURFACE } \\
\text { AND FREE FIELD } \\
\text { DATA } \\
\text { RR=-Round Robin } \\
\text { Surface gages } \\
\text { RTP=Recording } \\
\text { Trailer Park } \\
\text { ONl=Orientaion } \\
\text { to WP Not } \\
\text { Investigated }\end{array}$ \\
\hline LONGSHOT & UA EH5 & $\begin{array}{l}\text { LANL/DOD, Pre- } \\
\text { BANEBERRY, } \\
\text { Amchita Island, } \\
\text { WP in Andesite, } \\
\text { Most of } 13 \text { gages } \\
\text { below water table }\end{array}$ & None & None & None & None & None & $\begin{array}{l}\text { CrRU report scaled rree- } \\
\text { Field Peak Radial Stresses } \\
\text { from Underground Nuclear } \\
\text { Explosiona in Five Explosion } \\
\text { Media (U)", V. E. Wheeler/ } \\
\text { R. G. Preston, UOPKG 66- } \\
\text { 80, 12,/7/66, . Day, VUP- } \\
\text { 2701. Free-Field Peak } \\
\text { Particle Velocities and } \\
\text { Stresses fron Underground } \\
\text { Nuclear Explosions in a } \\
\text { LONGSHOT - type } \\
\text { Environment, R. G. Preston, } \\
\text { UOPKG 67-18, 4/26/67. } \\
\text { CFRD report "Peak Surface } \\
\text { Velocity from Nuclear } \\
\text { Explosions (U)", V. E. } \\
\text { Wheeler, UOPBA 73-44, } \\
\text { 3/16/73, . CFRD report } \\
\text { "Summary of Free Field } \\
\text { Ground Motion } \\
\text { Measurements (U)", V. E. } \\
\text { Wheeler/ R. G. Preston, } \\
\text { UOPBA 74-126, 8/21/74, } \\
\end{array}$ & $\begin{array}{l} \\
\text { WES report, VUF-2701, } \\
\text { Day and Murrell. UOPKG } \\
67-17, \text { Preston, } 4 / 24 / 67 .\end{array}$ & $\begin{array}{l}\text { Surface, Hor. } \\
\text { dist. (NI) (Ref. } \\
\text { UOPBA 73-44); } \\
\text { Subsurface, } 13 \\
\text { vertical GM } \\
\text { gages. (Ref. } \\
\text { UOPBA 74-126) } \\
\end{array}$ \\
\hline MADISON & & \begin{tabular}{|l} 
LLNL, Pre- \\
BANEBERRY \\
\end{tabular} & None & None & None & & & $\begin{array}{l}\text { CFRD report "Summary of } \\
\text { Free Field Ground Motion } \\
\text { Measurements (U)", V. E. } \\
\text { Wheeler/ R. G. Preston, } \\
\text { UOPBA 74-126, 8/21/74, } \\
\text {. CFRD report "Ground } \\
\text { Shock Predictions for } \\
\text { Underground Nuclear } \\
\text { Explosions in Rainier Mesa } \\
\text { (U)", L. F. Ingram, J. L. } \\
\text { Drake, DNA-TR-88-14, } \\
\text { 10/23/87,. }\end{array}$ & $\begin{array}{l}\text { SRI report WT-1865, } \\
\text { CFRD report "Tunnel } \\
\text { Dynamics- MADISON } \\
\text { Event (U)",W. M. Wells, } \\
\text { SRI report Project } 29.4 \\
\text { Data Report, } 8 / 5 / 63 \\
\end{array}$ & $\begin{array}{l}\text { Subsurface, } 2 \\
\text { GM gages (ONI) } \\
\text { (Ref. UOPBA 74- } \\
\text { 126), } 4 \text { SRI GM } \\
\text { (ONI) gages } \\
\text { (Ref. DNA-TR-88 } \\
\text { 14) }\end{array}$ \\
\hline
\end{tabular}


Ground Motion Data: Appendix 3B (John Rambo)

\begin{tabular}{|c|c|c|c|c|c|c|c|c|c|c|}
\hline This d & des in the & DNI Containment & $\begin{array}{c}\text { DATA } \\
\text { Early LLNL } \\
\text { processed data } \\
\text { and reports }\end{array}$ & $\begin{array}{c}\text { DATA } \\
\begin{array}{c}\text { Later EG\&G } \\
\text { processed data and } \\
\text { reports }\end{array}\end{array}$ & $\begin{array}{c}\text { DATA } \\
-\begin{array}{c}\text { Later data } \\
\text { processed at LLNL } \\
\text { by EG\&G }\end{array}\end{array}$ & \begin{tabular}{|c}
483, burkhard @ill \\
DATA \\
Data Plots, \\
Surface, \\
Subsurface \\
Ground Motion, \\
Pressure/ \\
Radiation \\
LOS/Displ./ Misc. \\
Similar Items are \\
included in this \\
column.
\end{tabular} & \begin{tabular}{|c|} 
DATA \\
Ground Motion at \\
Distance From \\
SGZ. Geophone \\
plots (yellow).
\end{tabular} & to & $\begin{array}{c}\text { SUMMARY AND FINAL } \\
\text { REPORTS } \\
\text { CONF=Classified CFRD } \\
\text { CDR=Containment Data } \\
\text { Report }\end{array}$ & $\begin{array}{l}\text { ski@|lnl.gov). } \\
\text { GAGE } \\
\text { LOCATIONS FOR } \\
\text { FREE SURFACE } \\
\text { AND FREE FIELD } \\
\text { DATA } \\
\text { RR=Round Robin } \\
\text { Surface gages } \\
\text { RTP=Recording } \\
\text { Trailer Park } \\
\text { ONl=Orientaion } \\
\text { to WP Not } \\
\text { Investigated }\end{array}$ \\
\hline MANTECA & U4al & & None & $\begin{array}{l}\text { CD of Compressed } \\
\text { Raw \& Processed } \\
\text { Data; CD of ASCII } \\
\text { Processed Data; } 2 \\
\text { Binders } \\
\end{array}$ & 1 Folder & None & None & $\begin{array}{l}\text { Binder Y, Binder T } \\
\text { (CLIPER/EXCOR) }\end{array}$ & $\begin{array}{l}\text { Containment } \\
\text { Measurements from } \\
\text { MANTECA" UOPKL 83-19 } \\
\text {; "Motion in the Stemming } \\
\text { Plugs on MANTECA" } \\
\text { UOPKL 83-13 } \\
\text {;"MANTECA Containment } \\
\text { Diagnostics" UOPKL 82- } \\
74 \text {; UCRL-ID-125014 } \\
\text { (CDR) }\end{array}$ & $\begin{array}{l}\text { Surface, Horiz. } \\
\text { Dist. 50' (Ref. } \\
\text { CDR): } \\
\text { Subsurface, No } \\
\text { free field gages, } \\
3 \text { GM gages in } \\
\text { Plugs (Ref. CDR) }\end{array}$ \\
\hline MANZANAS & U3gr & $\begin{array}{l}\text { LANL, Pre- } \\
\text { BANEBERRY. No } \\
\text { entries for ground } \\
\text { motion. }\end{array}$ & None & None & None & None & None & None & None & \\
\hline MARIBO & U2cs & LLNL & None & $\begin{array}{l}\text { CD of Compressed } \\
\text { Raw \& Processed } \\
\text { Data; CD of ASCII } \\
\text { Processed Data; } 1 \\
\text { Binder }\end{array}$ & 1 Folder & $\begin{array}{l}1 \text { Ground Motion } \\
\text { Roll (Blue), } 1 \text { Roll } \\
\text { of Pres./ } \\
\text { Radiation Traces } \\
\text { (Red) }\end{array}$ & None & $\begin{array}{l}\text { Binder X, Binder U (Peak } \\
\text { Accelleration of Trailers), } 5 \\
\text { Presentation Binders }\end{array}$ & UCRL-ID-121266 (CDR) & $\begin{array}{l}\text { Dist. 50' (Ref. } \\
\text { CDR): } \\
\text { Subsurface, No } \\
\text { free field gages, } \\
2 \text { GM gages in } \\
\text { Plugs (Ref. CDR) }\end{array}$ \\
\hline MARSILLY & U2el & LLNL & 1 Binder & $\begin{array}{l}\text { CD of Compressed } \\
\text { Raw \& Processed } \\
\text { Data }\end{array}$ & None & None & $\begin{array}{l}\text { Earth Strain Cals. } \\
\text {. Pathfinder CD } \\
\text { of Compressed } \\
\text { Raw \& Processed } \\
\text { Data }(\mathrm{V})\end{array}$ & None & $\begin{array}{l}\text { "Post-Operational Report } \\
\text { for the Containment } \\
\text { Diagnostics on MARSILLY, } \\
\text { U2el", UOPBA 77-99 }\end{array}$ & \\
\hline MERIDA & U2dn & LLNL & 3 Binders & $\begin{array}{l}\text { CD of Compressed } \\
\text { Raw \& Processed } \\
\text { Data }\end{array}$ & 1 Folder & None & \begin{tabular}{|l|} 
\\
\\
CONF report \\
"Round Robin \\
Program MERIDA \\
Event (U)", W. R. \\
Perret, Sandia \\
UOPBA 72-76, \\
6/27/72 (V). \\
\end{tabular} & $\begin{array}{l}\text { report "Peak Surface } \\
\text { Velocity from Nuclear } \\
\text { Explosions (U)", V. E. } \\
\text { Wheeler, UOPBA 73-44, } \\
\text { 3/16/73, . CFRD report } \\
\text { "Summary of Free Field } \\
\text { Ground Motion } \\
\text { Measurements (U)", V. E. } \\
\text { Wheeler/ R. G. Preston, } \\
\text { UOPBA 74-126, 8/21/74, } \\
\end{array}$ & $\begin{array}{l}\text { Draft Report "Response of } \\
\text { the Pinex Pipe in MERIDA" }\end{array}$ & $\begin{array}{l}\text { Surface (Ref. } \\
\text { RR) Horiz., 50', } \\
385,385^{\prime}, 384^{\prime} \\
\text { Subsurface } \\
\text { stemming gages } \\
\text { (Ref. UOPBA 74- } \\
\text { 126) } \\
\end{array}$ \\
\hline
\end{tabular}


Ground Motion Data: Appendix 3B (John Rambo)

\begin{tabular}{|c|c|c|c|c|c|c|c|c|c|c|}
\hline This d & ides in the & DNT Containme & Program files. Prog & $\begin{array}{c}\text { DATA } \\
\begin{array}{c}\text { Later EG\&G } \\
\text { processed data and } \\
\text { reports }\end{array} \\
\end{array}$ & \begin{tabular}{|c|} 
DATA \\
Later data \\
processed at LLNL \\
by EG\&G
\end{tabular} & \begin{tabular}{|c}
483, burkhard1 @lli \\
DATA \\
Data Plots, \\
Surface, \\
Subsurface \\
Ground Motion, \\
Pressure/ \\
Radiation \\
LOS/Displ./ Misc. \\
Similar Items are \\
included in this \\
column.
\end{tabular} & \begin{tabular}{|c} 
DATA \\
Ground Motion at \\
Distance From \\
SGZ. Geophone \\
plots (yellow).
\end{tabular} & Program Leader Gayle Paw & $\begin{array}{c}\text { SUMMARY AND FINAL } \\
\text { REPORTS } \\
\text { CONF=Classified CFRD } \\
\text { CDR=Containment Data } \\
\text { Report }\end{array}$ & $\begin{array}{l}\text { ski@llnl.gov). } \\
\text { GAGE } \\
\text { LOCATIONS FOR } \\
\text { FREE SURFACE } \\
\text { AND FREE FIELD } \\
\text { DATA } \\
\text { RR=Round Robin } \\
\text { Surface gages } \\
\text { RTP=Recording } \\
\text { Trailer Park } \\
\text { ONl=Orientaion } \\
\text { to WP Not } \\
\text { Investigated }\end{array}$ \\
\hline MERLIN & U3ct & $\begin{array}{l}\text { LANL, Pre- } \\
\text { BANEBERRY }\end{array}$ & None & None & None & None & None & $\begin{array}{l}\text { Velocity from Nuclear } \\
\text { Explosions (U)", V. E. } \\
\text { Wheeler, UOPBA 73-44, } \\
3 / 16 / 73, \text {. CFRD report } \\
\text { "Summary of Free Field } \\
\text { Ground Motion } \\
\text { Measurements (U)", V. E. } \\
\text { Wheeler/ R. G. Preston, } \\
\text { UOPBA 74-126, 8/21/74, }\end{array}$ & $\begin{array}{l}\text { "Free-Field and Surface } \\
\text { Motion fron a Nuclear } \\
\text { Explosion in Alluvium: } \\
\text { MERLIN Event" ; "Ground } \\
\text { Motion Analyses: OSSY (A } \\
\text { High Explosive } \\
\text { Experiment) and MERLIN } \\
\text { (A Nuclear Event)" Also } \\
\text { see Sandia report SC-RR- } \\
\text { 69-334. }\end{array}$ & $\begin{array}{l}\text { Surface, Hor. } \\
\text { dist. (NI) (Ref. } \\
\text { UOPBA 73-44); } \\
\text { Subsurface } 8 \\
\text { shot level GM } \\
\text { gages; } 10 \\
\text { verticle GM } \\
\text { gages (Ref. } \\
\text { UOPBA 74-126) } \\
\text { UulluU, ivil. }\end{array}$ \\
\hline METROPOLIS & U2gh & LLNL & None & $\begin{array}{l}\text { CD of Compressed } \\
\text { Raw \& Processed } \\
\text { Data; CD of ASCII } \\
\text { Processed Data; } 1 \\
\text { Binder }\end{array}$ & 2 Folders & None & None & $\begin{array}{l}\text { Binder T (CLIPER/EXCOR), } \\
\text { Binder S (SMIDS Collapse } \\
\text { Signals) }\end{array}$ & UCRL-MI-104930 (CDR) & $\begin{array}{l}\text { Dist. RTP } \\
\text { (Approx. 770') } \\
\text { (Ref. CDR): } \\
\text { Subsurface, No } \\
\text { free field gages, } \\
\text { No GM gages in } \\
\text { Plugs (Ref. CDR) }\end{array}$ \\
\hline MIDDLE NOTE & U12n.21 & LLNL/DOD & None & $\begin{array}{l}\text { Raw \& Processed } \\
\text { Data; CD of ASCII } \\
\text { Processed Data; } 1 \\
\text { Binder }\end{array}$ & 1 Folder & None & None & None & None & \\
\hline MIDIMIST & U12n.02 & $\begin{array}{l}\text { LLNL/DOD, Pre- } \\
\text { BANEBERRY }\end{array}$ & None & $\begin{array}{l}\text { Cu of Compressed } \\
\text { Raw \& Processed } \\
\text { Data }\end{array}$ & None & None & None & & None & \\
\hline MIDAS MYTH & U12t.04 & LANL/DOD & None & None & None & None & None & $\begin{array}{l}\text { Shock Predictions for } \\
\text { Underground Nuclear } \\
\text { Explosions in Rainier Mesa } \\
(\mathrm{U}) " \text {, L. F. Ingram, J. L. } \\
\text { Drake, DNA-TR-88-14, } \\
\text { 10/23/87, . }\end{array}$ & $\begin{array}{l}\text { Sandia , unreported (Bass } \\
\text { pri. Comm.) }\end{array}$ & $\begin{array}{l}\text { Subsurface, } 6 \\
\text { Sandia stress } \\
\text { gages, } 3 \text { Sandia } \\
\text { GM gages (Ref. } \\
\text { DNA-TR-88-14) }\end{array}$ \\
\hline MILKSHAKE & U5k & $\begin{array}{l}\text { LLNL/DOD, Pre- } \\
\text { BANEBERRY }\end{array}$ & None & $\begin{array}{l}\text { Raw \& Processed } \\
\text { Data }\end{array}$ & None & None & None & None & None & \\
\hline \begin{tabular}{|l|} 
MIERA \\
\end{tabular} & U7ad & LANL & None & 1 Binder & None & None & None & None & None & \\
\hline
\end{tabular}


Ground Motion Data: Appendix 3B (John Rambo)

\begin{tabular}{|c|c|c|c|c|c|c|c|c|c|c|}
\hline EVENT & HOLE & COMMENTS & $\begin{array}{c}\text { DATA } \\
\text { Early LLNL } \\
\text { processed data } \\
\text { and reports }\end{array}$ & $\mid \begin{array}{c}\text { DATA } \\
\begin{array}{c}\text { Later EG\&G } \\
\text { processed data and } \\
\text { reports }\end{array}\end{array}$ & $\begin{array}{c}\text { DATA } \\
\begin{array}{c}\text { Later data } \\
\text { processed at LLNL } \\
\text { by EG\&G }\end{array}\end{array}$ & \begin{tabular}{|c|} 
DATA \\
Data Plots, \\
Surface, \\
Subsurface \\
Ground Motion, \\
Pressure/ \\
Radiation \\
LOS/Displ./ Misc. \\
Similar Items are \\
included in this \\
column.
\end{tabular} & \begin{tabular}{|c|} 
DATA \\
Ground Motion at \\
Distance From \\
SGZ. Geophone \\
plots (yellow).
\end{tabular} & EVENT COMPARISONS & $\begin{array}{c}\text { SUMMARY AND FINAL } \\
\text { REPORTS } \\
\text { CONF=Classified CFRD } \\
\text { CDR=Containment Data } \\
\text { Report }\end{array}$ & $\begin{array}{c}\text { GAGE } \\
\text { LOCATIONS FOR } \\
\text { FREE SURFACE } \\
\text { AND FREE FIELD } \\
\text { DATA } \\
\text { RR=Round Robin } \\
\text { Surface gages } \\
\text { RTP=Recording } \\
\text { Trailer Park } \\
\text { ONl=Orientaion } \\
\text { to WP Not } \\
\text { Investigated }\end{array}$ \\
\hline MIGHTY EPIC & U12n.10 & LLNL/DOD & None & None & None & None & Earth Strain Cals. & $\begin{array}{l}\text { CFRD report "Ground } \\
\text { Shock Predictions for } \\
\text { Underground Nuclear } \\
\text { Explosions in Rainier Mesa } \\
\text { (U)", L. F. Ingram, J. L. } \\
\text { Drake, DNA-TR-88-14, } \\
\text { 10/23/87, . }\end{array}$ & $\begin{array}{l}\text { PI report POR 6954, WES } \\
\text { report DNA-6952F, Boing } \\
\text { report using Sandia data } \\
\text { POR } 6992 \text {, Sandia } \\
\text { unreported (Bass Pri. } \\
\text { Comm.) }\end{array}$ & \begin{tabular}{|l|} 
Subsurface, 13 \\
PI GM gages, 13 \\
WES GM gages, \\
2 WES stress \\
gages, 3 Sandia \\
stress gages, 1 \\
high-speed \\
photography GM \\
recordings \\
(Engineering \\
Decision Analysis \\
Co.) (Ref. Ref. \\
DNA-TR-88-14) \\
\end{tabular} \\
\hline MIGHTY OAK & U12t.08 & LLNL/DOD & None & None & None & None & None & 1 Presentation Binder . & $\begin{array}{l}\text { "MIGHTY OAK } \\
\text { Containment Review" } \\
\text { UCRL-100960 }\end{array}$ & \\
\hline MILROW & UA 2 & $\begin{array}{l}\text { Pre-BANEBERRY, } \\
\text { LANL, Most of } 12 \\
\text { gages below } \\
\text { water table. }\end{array}$ & 1 Binder & None & None & None & None & $\begin{array}{l}\text { Velocity from Nuclear } \\
\text { Explosions (U)", V. E. } \\
\text { Wheeler, UOPBA 73-44, } \\
\text { 3/16/73, . CFRD report } \\
\text { "Summary of Free Field } \\
\text { Ground Motion } \\
\text { Measurements (U)", V. E. } \\
\text { Wheeler/ R. G. Preston, } \\
\text { UOPBA 74-126, 8/21/74, } \\
\end{array}$ & $\begin{array}{l}\text { Sandia report, SC-RR } 71 \\
0668\end{array}$ & $\begin{array}{l}\text { Surface, Hor. } \\
\text { dist. (NI) (Ref. } \\
\text { UOPBA 73-44); } \\
\text { Subsurface, } 12 \\
\text { vertical GM } \\
\text { gages (Ref. } \\
\text { UOPBA 74-126) }\end{array}$ \\
\hline MINERS IRON & U12n.11 & LANL/DOD & None & None & None & None & None & $\begin{array}{l}\text { Shock Predictions for } \\
\text { Underground Nuclear } \\
\text { Explosions in Rainier Mesa } \\
\text { (U)", L. F. Ingram, J. L. } \\
\text { Drake, DNA-TR-88-14, } \\
\text { 10/23/87, . }\end{array}$ & $\begin{array}{l}\text { Sandia unreported (Bass } \\
\text { Pri. Comm.) }\end{array}$ & $\begin{array}{l}\text { Subsurface, } 1 \\
\text { Sandia stress } \\
\text { gage, } 1 \text { Sandia } \\
\text { GM gage (Ref. } \\
\text { DNA-TR-88-14). }\end{array}$ \\
\hline
\end{tabular}


Ground Motion Data: Appendix 3B (John Rambo)

\begin{tabular}{|c|c|c|c|c|c|c|c|c|c|c|}
\hline This d & HOLE & DNI Containme & $\begin{array}{c}\text { DATA } \\
\text { Early LLNL } \\
\text { processed data } \\
\text { and reports }\end{array}$ & $\mid \begin{array}{c}\text { DATA } \\
\begin{array}{c}\text { Later EG\&G } \\
\text { processed data and } \\
\text { reports }\end{array}\end{array}$ & $\begin{array}{c}\text { DATA } \\
- \text { Later data }^{\text {Lacessed at LLNL }} \\
\text { by EG\&G }\end{array}$ & $\begin{array}{c}\text { DATA } \\
\text { Data Plots, } \\
\text { Surface, } \\
\text { Subsurface } \\
\text { Ground Motion, } \\
\text { Pressure/ } \\
\text { Radiation } \\
\text { LOS/Displ./ Misc. } \\
\text { Similar Items are } \\
\text { included in this } \\
\text { column. }\end{array}$ & $\begin{array}{c}\text { DATA } \\
\text { Ground Motion at } \\
\text { Distance From } \\
\text { SGZ. Geophone } \\
\text { plots (yellow). }\end{array}$ & EVENT COMPARISONS & $\begin{array}{c}\text { SUMMARY AND FINAL } \\
\text { REPORTS } \\
\text { CONF=Classified CFRD } \\
\begin{array}{c}\text { CDR=Containment Data } \\
\text { Report }\end{array}\end{array}$ & $\begin{array}{l}\text { gski@llnl.gov). } \\
\text { GAGE } \\
\text { LOCATIONS FOR } \\
\text { FREE SURFACE } \\
\text { AND FREE FIELD } \\
\text { DATA } \\
\text { RR=Round Robin } \\
\text { Surface gages } \\
\text { RTP=Recording } \\
\text { Trailer Park } \\
\text { ONI=Orientaion } \\
\text { to WP Not } \\
\text { Investigated }\end{array}$ \\
\hline MING VASE & U16a.04 & $\begin{array}{l}\text { Pre-BANEBERRY, } \\
\text { LANL/DOD }\end{array}$ & None & & 1 Folder & None & None & $\begin{array}{l}\text { Shock Predictions for } \\
\text { Underground Nuclear } \\
\text { Explosions in Rainier Mesa } \\
\text { (U)", L. F. Ingram, J. L. } \\
\text { Drake, DNA-TR-88-14, } \\
\text { 10/23/87, . }\end{array}$ & None & $\begin{array}{l}\text { Subsurface, no } \\
\text { free field gages } \\
\text { (Ref.DNA-TR-88- } \\
\text { 14) }\end{array}$ \\
\hline MINIATA & U2bu & LLNL & 1 Binder & $\begin{array}{l}\text { CD of Compressed } \\
\text { Raw \& Processed } \\
\text { Data }\end{array}$ & 1 Folder & None & None & None & None & \\
\hline MINK & U3ae & $\begin{array}{l}\text { LANL, Pre- } \\
\text { BANEBERRY }\end{array}$ & None & None & None & None & None & $\begin{array}{l}\text { CHKU report "reak surtace } \\
\text { Velocity from Nuclear } \\
\text { Explosions (U)", V. E. } \\
\text { Wheeler, UOPBA 73-44, } \\
3 / 16 / 73 \text {, }\end{array}$ & None & $\begin{array}{l}\text { Surface, Hor. } \\
\text { dist. (NI) (Ref. } \\
\text { UOPBA 73-44) }\end{array}$ \\
\hline MINT LEAF & U12t.01 & $\begin{array}{l}\text { LLNL/DOD, Pre- } \\
\text { BANEBERRY }\end{array}$ & None & & None & None & None & $\begin{array}{l}\text { Shock Predictions for } \\
\text { Underground Nuclear } \\
\text { Explosions in Rainier Mesa } \\
\text { (U)", L. F. Ingram, J. L. } \\
\text { Drake, DNA-TR-88-14, } \\
\text { 10/23/87, . }\end{array}$ & $\begin{array}{l}\text { PI report POR } 6427 \text { or WT } \\
6427\end{array}$ & $\begin{array}{l}\text { Subsurface, } 6 \text { PI } \\
\text { GM gages (Ref. } \\
\text { DNA-TR-88-14) }\end{array}$ \\
\hline MISSION GHOST & U12t.09 & LANL/DOD & None & $\begin{array}{l}\text { Raw \& Processed } \\
\text { Data; CD of ASCII } \\
\text { Processed Data; } 1 \\
\text { Binder }\end{array}$ & 1 Folder & None & None & None & $\begin{array}{l}\text { "Cavity Pressure } \\
\text { Measurements and Gas } \\
\text { Sampling for MISSION } \\
\text { GHOST" UCID-21295 }\end{array}$ & \\
\hline MISTY NORTH & U12w.05 & LANL/DOD & None & None & None & None & $\begin{array}{l}\text { CONF report } \\
\text { "Round Robin } \\
\text { Program MISTY } \\
\text { NORTH Event } \\
\text { (U)", W. R. } \\
\text { Perret, Sandia } \\
\text { UOPBA 72-56, } \\
\text { 5/23/72 (V). } \\
\end{array}$ & $\begin{array}{l}\text { CFRD report "Peak Surface } \\
\text { Velocity from Nuclear } \\
\text { Explosions (U)", V. E. } \\
\text { Wheeler, UOPBA 73-44, } \\
3 / 16 / 73, \text {. CFRD report } \\
\text { "Ground Shock Predictions } \\
\text { for Underground Nuclear } \\
\text { Explosions in Rainier Mesa } \\
\text { (U)", L. F. Ingram, J. L. } \\
\text { Drake, DNA-TR-88-14, } \\
\text { 10/23/87, . }\end{array}$ & $\begin{array}{l}\mathrm{PI} \text {-eport POR-6658 or WT } \\
6658\end{array}$ & $\begin{array}{l}\text { Surface (Ref. } \\
\text { RR) Horiz., 0', } \\
616 ', 626 ', \\
618^{\prime} ; \\
\text { Subsurface, } 1 \text { PI } \\
\text { stress gage, 1 PI } \\
\text { GM gage } \\
\text { (Suspect?), (ref. } \\
\text { DNA-TR-88-14). }\end{array}$ \\
\hline
\end{tabular}


Ground Motion Data: Appendix 3B (John Rambo)

\begin{tabular}{|c|c|c|c|c|c|c|c|c|c|c|}
\hline 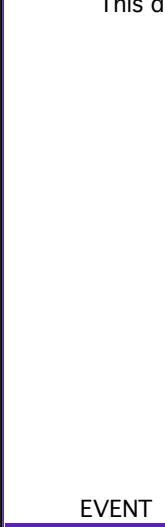 & HOLE & COMMENTS & $\begin{array}{l}\text { DATA } \\
\text { Early LLNL } \\
\text { processed data } \\
\text { and reports }\end{array}$ & $\begin{array}{c}\text { DATA } \\
\begin{array}{c}\text { Later EG\&G } \\
\text { processed data and } \\
\text { reports }\end{array}\end{array}$ & $\begin{array}{c}\text { DATA } \\
- \text { Later data } \\
\text { processed at LLNL } \\
\text { by EG\&G }\end{array}$ & \begin{tabular}{|c} 
DATA \\
----_a Plots, \\
Surface, \\
Subsurface \\
Ground Motion, \\
Pressure/ \\
Radiation \\
LOS/Displ./ Misc. \\
Similar Items are \\
included in this \\
column.
\end{tabular} & $\begin{array}{c}\text { DATA } \\
\text { Ground Motion at } \\
\text { Distance From } \\
\text { SGz. Geophone } \\
\text { plots (yellow). }\end{array}$ & 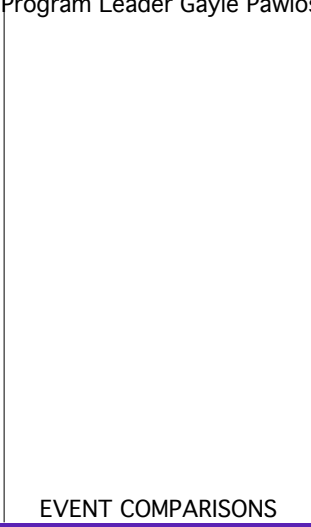 & $\begin{array}{c}\text { SUMMARY AND FINAL } \\
\text { REPORTS } \\
\text { CONF=Classified CFRD } \\
\text { CDR=Containment Data } \\
\text { Report }\end{array}$ & $\begin{array}{l}\text { GAII InI.gOV). } \\
\text { GAGE } \\
\text { LOCATIONS FOR } \\
\text { FREE SURFACE } \\
\text { AND FREE FIELD } \\
\text { DATA } \\
\text { RR=Round Robin } \\
\text { Surface gages } \\
\text { RTP=Recording } \\
\text { Trailer Park } \\
\text { ONI=Orientaion } \\
\text { to WP Not } \\
\text { Investigated }\end{array}$ \\
\hline MISTY RAIN & U12n.17 & DOD/LLNL & None & \begin{tabular}{|l|} 
CD of Compressed \\
Raw \& Processed \\
Data
\end{tabular} & None & None & None & None & None & \\
\hline MOLBO & U20ag & LLNL & None & \begin{tabular}{|l|} 
CD of Compressed \\
Raw \& Processed \\
Data; CD of ASCII \\
Processed Data; 1 \\
Binder
\end{tabular} & 1 Folder & None & None & & UCRL-ID-127716 (CDR) & $\begin{array}{l}\text { Surface, Horiz. } \\
\text { Dist. 50', 1042', } \\
1449 ', 2900^{\prime} \\
\text { (Ref. CDR): } \\
\text { Subsurface, No } \\
\text { free field gages, } \\
\text { No GM gages in } \\
\text { Plugs (Ref. CDR) }\end{array}$ \\
\hline MONERO & U3ja & LANL & None & None & None & None & None & $\begin{array}{l}\text { Velocity from Nuclear } \\
\text { Explosions (U)", V. E. } \\
\text { Wheeler, UOPBA 73-44, } \\
3 / 16 / 73 \text {, }\end{array}$ & 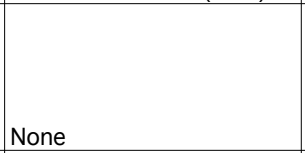 & $\begin{array}{l}\text { Surface, Hor. } \\
\text { dist. (NI) (Ref. } \\
\text { UOPBA 73-44) }\end{array}$ \\
\hline MONTELLO & U20bf & LLNL & None & \begin{tabular}{|l|} 
CD of Compressed \\
Raw \& Processed \\
Data; CD of ASCII \\
Processed Data; 1 \\
Binder
\end{tabular} & 1 Folder & None & None & None & None & $\begin{array}{l}\text { Dist. 50', RTP } \\
(1086 ') \text { (Ref. } \\
\text { CDR): } \\
\text { Subsurface, No } \\
\text { free field gages, } \\
\text { No GM gages in } \\
\text { Plugs (Ref. CDR) } \\
\end{array}$ \\
\hline MONTEREY & U20ai & LLNL & None & None & 1 Folder & None & None & Binder T (CLIPER/EXCOR) & None & \\
\hline MUDPACK & U1ON & $\begin{array}{l}\text { LLNL, Pre- } \\
\text { BANEBERRY, } 6 \\
\text { gages } \\
\text { incarbonate, } 4 \\
\text { gages in shale }\end{array}$ & None & None & None & None & None & $\begin{array}{l}\text { Velocity from Nuclear } \\
\text { Explosions (U)", V. E. } \\
\text { Wheeler, UOPBA 73-44, } \\
3 / 16 / 73, \text {. CFRD report } \\
\text { "Summary of Free Field } \\
\text { Ground Motion } \\
\text { Measurements (U)", V. E. } \\
\text { Wheeler/ R. G. Preston, } \\
\text { UOPBA 74-126, 8/21/74, }\end{array}$ & \begin{tabular}{|l|} 
"Ground Motion in a \\
Multilayered Earth, Part II: \\
Explosion in Desert \\
Alluvium, Project 1.1/1.2, \\
MUDPACK Event" Note: \\
See HANDCAR Event as a \\
Cross Reference. Also see \\
Sandia report POR-2900 \\
\end{tabular} & $\begin{array}{l}\text { Surface, Hor. } \\
\text { dist. (NI) (Ref. } \\
\text { UOPBA 73-44); } \\
\text { Subsurfsce 16 } \\
\text { off-set vertical } \\
\text { GM gages (Ref. } \\
\text { UOPBA 74-126) }\end{array}$ \\
\hline MUENSTER & U19e & LLNL & 2 Binders & $\begin{array}{l}\text { Raw \& Processed } \\
\text { Data }\end{array}$ & 1 Folder & 11 Data Listings & $\begin{array}{l}\text { Earth Strain } \\
\text { Cals., PDS Cals. }\end{array}$ & None & None & \\
\hline
\end{tabular}


Ground Motion Data: Appendix 3B (John Rambo)

\begin{tabular}{|c|c|c|c|c|c|c|c|c|c|c|}
\hline This data & des in the LL & (1) & $\begin{array}{c}\text { DATA } \\
\text { Early LLNL } \\
\text { processed data } \\
\text { and reports }\end{array}$ & $\begin{array}{c}\text { DATA } \\
\begin{array}{c}\text { Later EG\&G } \\
\text { processed data and } \\
\text { reports }\end{array}\end{array}$ & $\begin{array}{c}\text { DATA } \\
-1 \text { Later data } \\
\begin{array}{c}\text { processed at LLNL } \\
\text { by EG\&G }\end{array}\end{array}$ & \begin{tabular}{|c} 
DATA \\
-----_a Plots, \\
Surface, \\
Subsurface \\
Ground Motion, \\
Pressure/ \\
Radiation \\
LOS/Displ./ Misc. \\
Similar Items are \\
included in this \\
column.
\end{tabular} & \begin{tabular}{|c|} 
DATA \\
Ground Motion at \\
Distance From \\
SGZ. Geophone \\
plots (yellow).
\end{tabular} & EVENT COMPARISONS & $\begin{array}{c}\text { SUMMARY AND FINAL } \\
\text { REPORTS } \\
\text { CONF=Classified CFRD } \\
\text { CDR=Containment Data } \\
\text { Report }\end{array}$ & $\begin{array}{l}\text { ski@llnl.gov). } \\
\text { GAGE } \\
\text { LOCATIONS FOR } \\
\text { FREE SURFACE } \\
\text { AND FREE FIELD } \\
\text { DATA } \\
\text { RR=Round Robin } \\
\text { Surface gages } \\
\text { RTP=Recording } \\
\text { Trailer Park } \\
\text { ONI=Orientaion } \\
\text { to WP Not } \\
\text { Investigated }\end{array}$ \\
\hline $\begin{array}{l}\text { NAMA AMARLYLIS } \\
\text { NAMA MEPHISTO }\end{array}$ & $\begin{array}{l}\text { U9IXY-31 U9I Z. } \\
27\end{array}$ & LLNL & None & None & None & None & $\begin{array}{l}\text { CONF report } \\
\text { "Round Robin } \\
\text { Program NAMA } \\
\text { and BALTIC } \\
\text { Events (U)", W. } \\
\text { R. Perret, Sandia } \\
\text { UOPBA \#001, } \\
\text { 9/1/71 (V). } \\
\end{array}$ & None & None & $\begin{array}{l}\text { Surface (Ref. } \\
\text { RR)Horiz., 400', } \\
50^{\prime}, 50^{\prime}\end{array}$ \\
\hline NAMA (BALTIC) & U9I S 25 & $\begin{array}{l}\text { May also be } \\
\text { referred to as } \\
\text { BALTIC Event }\end{array}$ & None & None & None & None & $\begin{array}{l}\text { CONF report } \\
\text { "Round Robin } \\
\text { Program NAMA } \\
\text { and BALTIC } \\
\text { Events (U)", W. } \\
\text { R. Perret, Sandia } \\
\text { UOPBA \#001, } \\
\text { 9/1/71 (V). } \\
\end{array}$ & & None & \\
\hline NEWPOINT & U11c & $\begin{array}{l}\text { LLNL/DOD, Pre- } \\
\text { BANEBERRY }\end{array}$ & None & None & None & None & None & $\begin{array}{l}\text { CFRD report "reak surrace } \\
\text { Velocity from Nuclear } \\
\text { Explosions (U)", V. E. } \\
\text { Wheeler, UOPBA 73-44, } \\
3 / 16 / 73 \text {, }\end{array}$ & None & $\begin{array}{l}\text { Surface, Hor. } \\
\text { dist. (NI) (Ref. } \\
\text { UOPBA 73-44) }\end{array}$ \\
\hline NIZA & $\mathrm{U} 2 \mathrm{cr}$ & LLNL & None & \begin{tabular}{|l|} 
CD of Compressed \\
Raw \& Processed \\
Data; CD of ASCII \\
Processed Data \\
\end{tabular} & 1 Folder & $\begin{array}{l}6 \text { Ground Motion } \\
\text { Rolls in } 3 \text { Boxes ; } \\
2 \text { Pres. and } \\
\text { Radiation Rolls in } \\
1 \text { Box } \\
\end{array}$ & None & Binder T (CLIPER/EXCOR) & $\begin{array}{l}\text { "Motion Response of the } \\
\text { Emplacement Pipe and } \\
\text { Stemming Plugs on the } \\
\text { Event NIZA" UOPKL } 81-75 \\
\text {; UCRL-ID-127721 (CDR) }\end{array}$ & $\begin{array}{l}\text { Dist. 50' (Ref. } \\
\text { CDR): } \\
\text { Subsurface, No } \\
\text { free field gages, } \\
3 \text { GM gages in } \\
\text { Plugs (Ref. CDR) }\end{array}$ \\
\hline NOGGIN & U9bx & $\begin{array}{l}\text { LLNL, Pre- } \\
\text { BANEBERRY }\end{array}$ & 4 Binders & $\begin{array}{l}\text { CD of Compressed } \\
\text { Raw \& Processed } \\
\text { Data }\end{array}$ & None & None & None & $\begin{array}{l}\text { Velocity from Nuclear } \\
\text { Explosions (U)", V. E. } \\
\text { Wheeler, UOPBA 73-44, } \\
3 / 16 / 73, \text {. CFRD report } \\
\text { "Summary of Free Field } \\
\text { Ground Motion } \\
\text { Measurements (U)", V. E. } \\
\text { Wheeler/ R. G. Preston, } \\
\text { UOPBA 74-126, 8/21/74, }\end{array}$ & $\begin{array}{l}\text { LLL/EG\&G report UCID- } \\
15488\end{array}$ & $\begin{array}{l}\text { Surface, Hor. } \\
\text { dist. (NI) (Ref. } \\
\text { UOPBA 73-44); } \\
9 \text { GM (ONI) } \\
\text { gages (Ref. } \\
\text { UOPBA 74-126) } \\
\end{array}$ \\
\hline
\end{tabular}


Ground Motion Data: Appendix 3B (John Rambo)

\begin{tabular}{|c|c|c|c|c|c|c|c|c|c|c|}
\hline Inis c & HOLE & COMMENTS & $\begin{array}{c}\text { DATA } \\
\text { Early LLNL } \\
\text { processed data } \\
\text { and reports }\end{array}$ & $\begin{array}{c}\text { DATA } \\
\begin{array}{c}\text { Later EG\&G } \\
\text { processed data and } \\
\text { reports }\end{array}\end{array}$ & $\begin{array}{c}\text { DATA } \\
-1 \text { Later data } \\
\begin{array}{c}\text { processed at LLNL } \\
\text { by EG\&G }\end{array}\end{array}$ & \begin{tabular}{|c|} 
DATA \\
Data Plots, \\
Surface, \\
Subsurface \\
Ground Motion, \\
Pressure/ \\
Radiation \\
LOS/Displ./ Misc. \\
Similar Items are \\
included in this \\
column.
\end{tabular} & \begin{tabular}{|c|} 
DATA \\
Ground Motion at \\
Distance From \\
SGZ. Geophone \\
plots (yellow).
\end{tabular} & 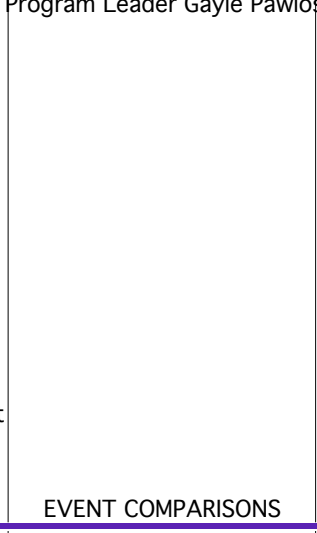 & $\begin{array}{c}\text { SUMMARY AND FINAL } \\
\text { REPORTS } \\
\text { CONF=Classified CFRD } \\
\begin{array}{c}\text { CDR=Containment Data } \\
\text { Report }\end{array} \\
\end{array}$ & $\begin{array}{c}\text { GSkI@ilni.gov). } \\
\text { GAGE } \\
\text { LOCATIONS FOR } \\
\text { FREE SURFACE } \\
\text { AND FREE FIELD } \\
\text { DATA } \\
\text { RR=Round Robin } \\
\text { Surface gages } \\
\text { RTP=Recording } \\
\text { Trailer Park } \\
\text { ONI=Orientaion } \\
\text { to WP Not } \\
\text { Investigated }\end{array}$ \\
\hline NORBO & U8c & LLNL & None & $\begin{array}{l}\text { CD of Compressed } \\
\text { Raw \& Processed } \\
\text { Data; CD of ASCII } \\
\text { Processed Data; } 1 \\
\text { Early Time Motion } \\
\text { Binder, } 1 \text { Collapse, } \\
\text { Stress Binder, } \\
\end{array}$ & 1 Folder & $\begin{array}{l}1 \text { Ground Motion } \\
\text { Roll (Blue) }\end{array}$ & Earth Strain Cals. & \begin{tabular}{|l} 
Binder U (Peak \\
Accelleration of Trailers), \\
Binder T (CLIPER/EXCOR). \\
"Analysis of Near Field \\
Ground Motion from \\
Nuclear Detonations in \\
High Porosity Media, R. T. \\
Terhune, M. Heusinkveld, \\
Proceedings of the Second \\
Symposium of \\
Underground Nuclear \\
Explosions, Albuquerque \\
\end{tabular} & UCRL-ID-123238 (CDR) & $\begin{array}{l}\text { Surface, Horiz. } \\
\text { Dist. 50' (Ref. } \\
\text { CDR): } \\
\text { Subsurface, Free } \\
\text { field gages, } 10 \\
\text { vertical offset } \\
\text { GM gages, } 3 \\
\text { vertical offset } \\
\text { stress gages, } 2 \\
\text { GM gages in } \\
\text { Plugs (Ref. CDR) }\end{array}$ \\
\hline NORMANNA & U10cb & LLNL & None & \begin{tabular}{|l|} 
CD of Compressed \\
Raw \& Processed \\
Data; CD of ASCII \\
Processed Data; 1 \\
Binder \\
\end{tabular} & 2 Folders & $\begin{array}{l}2 \text { Ground Motion } \\
\text { Rolls (Blue) }\end{array}$ & None & None & & $\begin{array}{l}\text { Surface, Horiz. } \\
\text { Dist. 177' (Ref. } \\
\text { CDR): } \\
\text { Subsurface, Free } \\
\text { field gages, } 7 \\
\text { vertical offset } \\
\text { GM gages, } 7 \\
\text { vertical offset } \\
\text { stress gages, No } \\
\text { GM gages in } \\
\text { Plugs (Ref. CDR) }\end{array}$ \\
\hline OAKLAND & U2bi & $\begin{array}{l}\text { LLNL, Pre- } \\
\text { BANEBERRY }\end{array}$ & None & None & None & None & None & None & $\begin{array}{l}\text { Emplacement Pipe and } \\
\text { Casing on OAKLAND } \\
\text { Containment Technical } \\
\text { Note No. } 27 \text { (U), UOPBA } \\
72-10,2 / 23 / 72,(U) " \text { C. } \\
\text { W. Olsen, TEC NOTE 27, } \\
\text { 4/27/67. }\end{array}$ & \\
\hline OARLOCK & U $3 \mathrm{~km}$ & LANL & None & None & None & None & $\begin{array}{l}\text { Earth Strain } \\
\text { Cals., PDS Cals. }\end{array}$ & None & None & \\
\hline
\end{tabular}


Ground Motion Data: Appendix 3B (John Rambo)

\begin{tabular}{|c|c|c|c|c|c|c|c|c|c|c|}
\hline This o & les in the & DNI Containment & Program files. Prog & $\mid \begin{array}{c}\text { DATA } \\
\begin{array}{c}\text { Later EG\&G } \\
\text { processed data and } \\
\text { reports }\end{array}\end{array}$ & $\begin{array}{c}\text { DATA } \\
-\begin{array}{c}\text { Later data } \\
\text { processed at LLNL } \\
\text { by EG\&G }\end{array}\end{array}$ & \begin{tabular}{|c|} 
DATA \\
Data Plots, \\
Surface, \\
Subsurface \\
Ground Motion, \\
Pressure/ \\
Radiation \\
LOS/Displ./ Misc. \\
Similar Items are \\
included in this \\
column.
\end{tabular} & \begin{tabular}{|c|} 
DATA \\
Ground Motion at \\
Distance From \\
SGZ. Geophone \\
plots (yellow).
\end{tabular} & 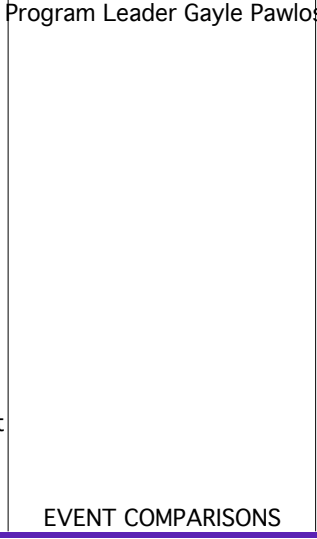 & $\begin{array}{c}\text { SUMMARY AND FINAL } \\
\text { REPORTS } \\
\text { CONF=Classified CFRD } \\
\text { CDR=Containment Data } \\
\text { Report }\end{array}$ & $\begin{array}{c}\text { oski@llnl.gov). } \\
\text { GAGE } \\
\text { LOCATIONS FOR } \\
\text { FREE SURFACE } \\
\text { AND FREE FIELD } \\
\text { DATA } \\
\text { RR=Round Robin } \\
\text { Surface gages } \\
\text { RTP=Recording } \\
\text { Trailer Park } \\
\text { ONI=Orientaion } \\
\text { to WP Not } \\
\text { Investigated }\end{array}$ \\
\hline OCATE & U3jp & $\begin{array}{l}\text { LANL, } 40 \mathrm{~ms} \text { after } \\
\text { ONAJA }\end{array}$ & None & None & None & None & $\begin{array}{l}\text { "Round Robin } \\
\text { Program ONAJA } \\
\text { \& OCATE Events } \\
\text { (U)", W. R. } \\
\text { Perret, Sandia } \\
\text { UOPBA } 72-50, \\
5 / 3 / 72(\mathrm{~V}) . \\
\end{array}$ & None & None & $\begin{array}{l}\text { Surface (Ref. } \\
\text { RR) Horiz., 50', } \\
344^{\prime}, 343^{\prime}, 344^{\prime}\end{array}$ \\
\hline ONAJA & U3js & LANL & None & None & None & None & $\begin{array}{l}\text { "Round Robin } \\
\text { Program ONAJA } \\
\text { \& OCATE Events } \\
\text { (U)", W. R. } \\
\text { Perret, Sandia } \\
\text { UOPBA } 72-50, \\
\text { 5/3/72 (V). } \\
\end{array}$ & None & None & $\begin{array}{l}\text { Surface (Ref. } \\
\text { RR) Horiz., } \\
50 ', 450 ', 661 \text { ', } \\
458 \text { ', } 457^{\prime}\end{array}$ \\
\hline ORKNEY & U10be & LLNL & None & $\begin{array}{l}\text { CD of Compressed } \\
\text { Raw \& Processed } \\
\text { Data; CD of ASCII } \\
\text { Processed Data; } 1 \\
\text { Binder } \\
\end{array}$ & 2 Folders & None & None & $\begin{array}{l}\text { Binder X, Binder T } \\
\text { (CLIPER/EXCOR), } 3 \\
\text { Presentation Binders }\end{array}$ & UCRL-ID-120650 (CDR) & $\begin{array}{l}\text { Dist. 50' (Ref. } \\
\text { CDR): } \\
\text { Subsurface, No } \\
\text { free field gages, } \\
3 \text { GM gages in } \\
\text { Plugs (Ref. CDR) }\end{array}$ \\
\hline OSCURO & U7z & LANL & None & 1 Binder & None & None & None & $\begin{array}{l}\text { Explosions (U)", V. E. } \\
\text { Wheeler, UOPBA 73-44, } \\
3 / 16 / 73 \text {, }\end{array}$ & None & $\begin{array}{l}\text { Surface, Hor. } \\
\text { dist. (NI) (Ref. } \\
\text { UOPBA 73-44) }\end{array}$ \\
\hline PACKARD & $\mathrm{U} 2 \mathrm{u}$ & $\begin{array}{l}\text { LLNL, Pre- } \\
\text { BANEBERRY }\end{array}$ & 11 Binders & $\begin{array}{l}\text { CD of Compressed } \\
\text { Raw \& Processed } \\
\text { Data }\end{array}$ & 1 Folder & None & None & $\begin{array}{l}\text { "Peak Surface Velocity } \\
\text { from Nuclear Explosions } \\
\text { (U)", V. E. Wheeler, UOPBA } \\
\text { 73-44, 3/16/73, . CFRD } \\
\text { report "Summary of Free } \\
\text { Field Ground Motion } \\
\text { Measurements (U)", V. E. } \\
\text { Wheeler/ R. G. Preston, } \\
\text { UOPBA 74-126, 8/21/74, }\end{array}$ & $\begin{array}{l}\text { "Response of the Pipe and } \\
\text { Ground in the PACKARD } \\
\text { Nuclear Effects Test" . } \\
\text { Also see LLNL/EG\&G } \\
\text { report UCRL-51112 } \\
\end{array}$ & $\begin{array}{l}\text { Surface, Hor. } \\
\text { dist. (NI) (Ref. } \\
\text { UOPBA 73-44); } \\
\text { Subsurface, } 2 \\
\text { shot level GM } \\
\text { gages, } 14 \\
\text { verticle GM } \\
\text { gages (Ref. } \\
\text { UOPBA 74-126) } \\
\end{array}$ \\
\hline
\end{tabular}


Ground Motion Data: Appendix 3B (John Rambo)

\begin{tabular}{|c|c|c|c|c|c|c|c|c|c|c|}
\hline This & des in the & N Containn & $\begin{array}{c}\text { DATA } \\
\text { Early LLNL } \\
\text { processed data } \\
\text { and reports } \\
\end{array}$ & $\begin{array}{c}\text { DATA } \\
\text { Later EG\&G } \\
\begin{array}{c}\text { processed data and } \\
\text { reports }\end{array}\end{array}$ & $\begin{array}{c}\text { DATA } \\
- \text { Later data } \\
\text { processed at LLNL } \\
\text { by EG\&G }\end{array}$ & \begin{tabular}{|c|} 
DATA \\
Data Plots, \\
Surface, \\
Subsurface \\
Ground Motion, \\
Pressure/ \\
Radiation \\
LOS/Displ./ Misc. \\
Similar Items are \\
included in this \\
column.
\end{tabular} & \begin{tabular}{|c|} 
DATA \\
Ground Motion at \\
Distance From \\
SGZ. Geophone \\
plots (yellow).
\end{tabular} & 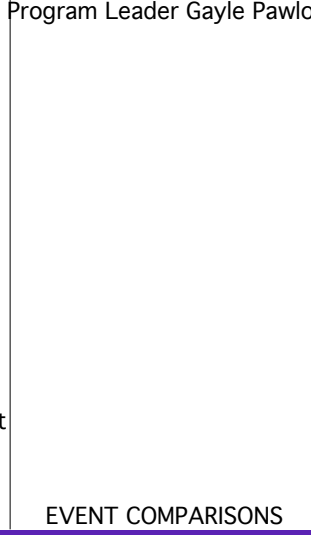 & $\begin{array}{c}\text { SUMMARY AND FINAL } \\
\text { REPORTS } \\
\text { CONF=Classified CFRD } \\
\text { CDR=Containment Data } \\
\text { Report }\end{array}$ & $\begin{array}{c}\text { ski@llnl.gov). } \\
\text { GAGE } \\
\text { LOCATIONS FOR } \\
\text { FREE SURFACE } \\
\text { AND FREE FIELD } \\
\text { DATA } \\
\text { RR=Round Robin } \\
\text { Surface gages } \\
\text { RTP=Recording } \\
\text { Trailer Park } \\
\text { ONI=Orientaion } \\
\text { to WP Not } \\
\text { Investigated }\end{array}$ \\
\hline PACKRAT & U3aw & $\begin{array}{l}\text { LANL, Pre- } \\
\text { BANEBERRY }\end{array}$ & None & None & None & None & None & $\begin{array}{l}\text { CFRU report "Peak Surrace } \\
\text { Velocity from Nuclear } \\
\text { Explosions (U)", V. E. } \\
\text { Wheeler, UOPBA 73-44, } \\
3 / 16 / 73 \text {, }\end{array}$ & None & $\begin{array}{l}\text { Surface, Hor. } \\
\text { dist. (NI) (Ref. } \\
\text { UOPBA 73-44) }\end{array}$ \\
\hline PALISADE & U4at & LLNL & 2 Binders & $\begin{array}{l}\text { CD of Compressed } \\
\text { Raw \& Processed } \\
\text { Data; CD of ASCII } \\
\text { Processed Data; } 1 \\
\text { Binder }\end{array}$ & 2 Folders & None & None & $\begin{array}{l}\text { Binder V, Binder T } \\
\text { (CLIPER/EXCOR), } 1 \\
\text { Presentation Binder }\end{array}$ & MISC-4821 (CDR) & $\begin{array}{l}\text { Dist. 50', 700', } \\
1400 ', \text { RTP (Ref. } \\
\text { CDR): } \\
\text { Subsurface, No } \\
\text { free field gages, } \\
5 \text { GM gages in } \\
\text { Plugs (Ref. CDR) }\end{array}$ \\
\hline PANAMINT & U2gb & LLNL & None & $\begin{array}{l}\text { CD of Compressed } \\
\text { Raw \& Processed } \\
\text { Data; CD of ASCII } \\
\text { Processed Data; } 1 \\
\text { Binder }\end{array}$ & 2 Folders & \begin{tabular}{|l|}
1 Pres./ Radiation \\
Printout Roll \\
(Red)
\end{tabular} & None & $\begin{array}{l}\text { Binder W, Binder U (Peak } \\
\text { Accelleration of Trailers), } \\
\text { Binder T (CLIPER/EXCOR), } \\
4 \text { Presentation Binders } \\
\end{array}$ & UCRL-ID-120480 (CDR) & $\begin{array}{l}\text { Dist. 50', RTP } \\
\text { (Ref. CDR): } \\
\text { Subsurface, No } \\
\text { free field gages, } \\
3 \text { GM gages in } \\
\text { Plugs (Ref. CDR) }\end{array}$ \\
\hline PANCHUELA & U3mg & LANL & None & None & None & None & None & 3 Presentation Binders & None & \\
\hline PANIR & U19y S & LLNL & None & $\begin{array}{l}\text { CD of Compressed } \\
\text { Raw \& Processed } \\
\text { Data }\end{array}$ & None & None & Earth Strain Cals. & Binder T (CLIPER/EXCOR) & None & \\
\hline PARNASSIA & $\mathrm{U} 2 \mathrm{bc}$ & & 2 Binders & 更 & 1 Folder & None & \begin{tabular}{|l|} 
\\
\\
\\
CONF report \\
"Round Robin \\
Program \\
PARNASSIA \\
Event (U)", W. R. \\
Perret, Sandia No \\
Document \#, \\
12/9/71 (V). \\
\end{tabular} & $\begin{array}{l}\text { Binders H, L, O, CFRD } \\
\text { report "Trapped Stress } \\
\text { Waves in Underground } \\
\text { Nuclear Explosions (U)", V. } \\
\text { E. Wheeler, R. G. Preston, } \\
\text { C. E. Frerking, UCRL- } \\
52012, \text {. CFRD report } \\
\text { "Peak Surface Velocity } \\
\text { from Nuclear Explosions } \\
\text { (U)", V. E. Wheeler, UOPBA } \\
73-44,3 / 16 / 73, \text {. CFRD } \\
\text { report "Summary of Free } \\
\text { Field Ground Motion } \\
\text { Measurements (U)", V. E. } \\
\text { Wheeler/ R. G. Preston, } \\
\text { UOPBA 74-126, 8/21/74, }\end{array}$ & None & $\begin{array}{l}\text { Surface (Ref. } \\
\text { RR) Horiz., 51' } \\
530^{\prime}, 530^{\prime}, \\
540^{\prime} ; \\
\text { Subsurface, } \\
\text { stemming gages } \\
\text { (Ref. UOPBA 74- } \\
126 \text { ) } \\
\end{array}$ \\
\hline
\end{tabular}


Ground Motion Data: Appendix 3B (John Rambo)

\begin{tabular}{|c|c|c|c|c|c|c|c|c|c|c|}
\hline This d & ides in th & DNT Containme & $\begin{array}{c}\text { DATA } \\
\text { Early LLNL } \\
\text { processed data } \\
\text { and reports }\end{array}$ & $\begin{array}{c}\text { DATA } \\
\text { Later EG\&G } \\
\begin{array}{c}\text { processed data and } \\
\text { reports }\end{array}\end{array}$ & $\begin{array}{c}\text { DATA } \\
- \text { Later data } \\
\begin{array}{c}\text { processed at LLNL } \\
\text { by EG\&G }\end{array}\end{array}$ & \begin{tabular}{|c|} 
DATA \\
Data Plots, \\
Surface, \\
Subsurface \\
Ground Motion, \\
Pressure/ \\
Radiation \\
LOS/Displ./ Misc. \\
Similar Items are \\
included in this \\
column.
\end{tabular} & $\begin{array}{c}\text { DATA } \\
\text { Ground Motion at } \\
\text { Distance From } \\
\text { SGZ. Geophone } \\
\text { plots (yellow). }\end{array}$ & Program Leader Gayle Pawlo & $\begin{array}{c}\text { SUMMARY AND FINAL } \\
\text { REPORTS } \\
\text { CONF=Classified CFRD } \\
\text { CDR=Containment Data } \\
\text { Report }\end{array}$ & $\begin{array}{l}\text { ski@llnl.gov). } \\
\text { GAGE } \\
\text { LOCATIONS FOR } \\
\text { FREE SURFACE } \\
\text { AND FREE FIELD } \\
\text { DATA } \\
\text { RR=Round Robin } \\
\text { Surface gages } \\
\text { RTP=Recording } \\
\text { Trailer Park } \\
\text { ONI=Orientaion } \\
\text { to WP Not } \\
\text { Investigated }\end{array}$ \\
\hline PEPATO & U20ad & LLNL & None & $\begin{array}{l}\text { CD of Compressed } \\
\text { Raw \& Processed } \\
\text { Data }\end{array}$ & 1 Folder & $\begin{array}{l}1 \text { CLIPER Printout } \\
\text { (Blue) }\end{array}$ & None & None & None & \\
\hline PERA & U10bd & LLNL & None & $\begin{array}{l}\text { CD of Compressed } \\
\text { Raw \& Processed } \\
\text { Data; CD of ASCII } \\
\text { Processed Data; } 1 \\
\text { Binder } \\
\end{array}$ & 1 Folder & $\begin{array}{l}2 \text { Ground Motion } \\
\text { Rolls (Blue) }\end{array}$ & None & $\begin{array}{l}\text { Binder S (SMIDS Collapse } \\
\text { Signals). "Analysis of Near } \\
\text { Field Ground Motion from } \\
\text { Nuclear Detonations in } \\
\text { High Porosity Media, R. T. } \\
\text { Terhune, M. Heusinkveld, } \\
\text { Proceedings of the Second } \\
\text { Symposium of } \\
\text { Underground Nuclear } \\
\text { Explosions, Albuquerque } \\
\text { NM, 8/2-4/83, Vol2 }\end{array}$ & $\begin{array}{l}\text { Draft Report "Final } \\
\text { Report: Free-Field and } \\
\text { Collapse Ground Motion } \\
\text { from the Underground } \\
\text { Nuclear Event, PERA" ; } \\
\text { UCRL-ID-128633 (CDR) }\end{array}$ & $\begin{array}{l}\text { Surface, Horiz. } \\
\text { Dist. 50' (Ref. } \\
\text { CDR): } \\
\text { Subsurface, Free } \\
\text { field gages, } 12 \\
\text { vertical offset } \\
\text { gages, } 8 \text { vertical } \\
\text { offset stress } \\
\text { gages, } 2 \text { GM } \\
\text { gages in Plugs } \\
\text { (Ref. CDR) } \\
\end{array}$ \\
\hline PILEDRIVER & U15a.01 & $\begin{array}{l}\text { LANL/DOD, Pre- } \\
\text { BANEBERRY, } \\
\text { Granite Site }\end{array}$ & None & None & None & \begin{tabular}{|l||} 
Misc. Roll of \\
Drawings showing \\
gage locations \\
and other \\
construction \\
related items. \\
(Green)
\end{tabular} & None & $\begin{array}{l}\text { CFRD report "Peak Surface } \\
\text { Velocity from Nuclear } \\
\text { Explosions (U)", V. E. } \\
\text { Wheeler, UOPBA 73-44, } \\
\text { 3/16/73, . CFRD report } \\
\text { "Summary of Free Field } \\
\text { Ground Motion } \\
\text { Measurements (U)", V. E. } \\
\text { Wheeler/ R. G. Preston, } \\
\text { UOPBA 74-126, 8/21/74, }\end{array}$ & $\begin{array}{l}\text { SRI report POR 4000, } \\
\text { Sandia report POR } 4001\end{array}$ & $\begin{array}{l}\text { Surface, Hor. } \\
\text { dist. (NI) (Ref. } \\
\text { UOPBA 73-44); } \\
\text { Subsurface, } 16 \\
\text { shot level GM } \\
\text { gages, } 11 \\
\text { vertical GM } \\
\text { gages (Ref. } \\
\text { UOPBA 74-126) }\end{array}$ \\
\hline PINEDROPS & U10as & LLNL & None & None & None & None & None & Binder M & None & \\
\hline PIN STRIPE & U11b & $\begin{array}{l}\text { LLNL/DOD, Pre- } \\
\text { BANEBERRY }\end{array}$ & None & None & None & None & None & $\begin{array}{l}\text { Explosions (U)", V. E. } \\
\text { Wheeler, UOPBA 73-44, } \\
3 / 16 / 73 \text {, }\end{array}$ & None & $\begin{array}{l}\text { Surface, Hor. } \\
\text { dist. (NI) (Ref. } \\
\text { UOPBA 73-44) }\end{array}$ \\
\hline PIPKIN & U20b & $\begin{array}{l}\text { LLNL, Pre- } \\
\text { BANEBERRY }\end{array}$ & None & None & None & None & $\begin{array}{l}1 \text { Wide } \\
\text { Geophone Roll } \\
\text { (Yellow) }\end{array}$ & Binder A & None & \\
\hline PLATYPUS & U3ad & $\begin{array}{l}\text { LANL, Pre- } \\
\text { BANEBERRY }\end{array}$ & None & None & None & None & None & $\begin{array}{l}\text { Velocity from Nuclear } \\
\text { Explosions (U)", V. E. } \\
\text { Wheeler, UOPBA } 73-44, \\
3 / 16 / 73 \text {, }\end{array}$ & None & $\begin{array}{l}\text { Surface, Hor. } \\
\text { dist. (NI) (Ref. } \\
\text { UOPBA 73-44) }\end{array}$ \\
\hline
\end{tabular}


Ground Motion Data: Appendix 3B (John Rambo)

\begin{tabular}{|c|c|c|c|c|c|c|c|c|c|c|}
\hline 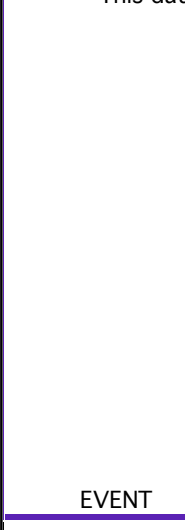 & HOLE & 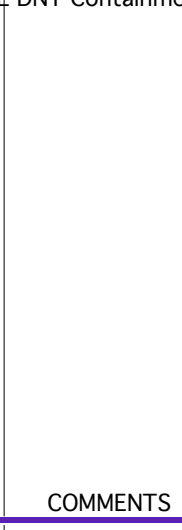 & $\begin{array}{c}\text { DATA } \\
\text { Early LLNL } \\
\text { processed data } \\
\text { and reports } \\
\end{array}$ & $\begin{array}{c}\text { DATA } \\
\begin{array}{c}\text { Later EG\&G } \\
\text { processed data and } \\
\text { reports }\end{array} \\
\end{array}$ & $\begin{array}{c}\text { DATA } \\
\text { Later data } \\
\text { processed at LLNL } \\
\text { by EG\&G }\end{array}$ & \begin{tabular}{|c} 
DATA \\
- Data Plots, \\
Surface, \\
Subsurface \\
Ground Motion, \\
Pressure/ \\
Radiation \\
LOS/Displ./ Misc. \\
Similar Items are \\
included in this \\
column.
\end{tabular} & $\begin{array}{c}\text { DATA } \\
\text { Ground Motion at } \\
\text { Distance From } \\
\text { SGZ. Geophone } \\
\text { plots (yellow). }\end{array}$ & Program Leader Gayle Paw & $\begin{array}{c}\text { SUMMARY AND FINAL } \\
\text { REPORTS } \\
\text { CONF=Classified CFRD } \\
\text { CDR=Containment Data } \\
\text { Report }\end{array}$ & $\begin{array}{l}\text { gski@llnl.gov). } \\
\text { GAGE } \\
\text { LOCATIONS FOR } \\
\text { FREE SURFACE } \\
\text { AND FREE FIELD } \\
\text { DATA } \\
\text { RR=Round Robin } \\
\text { Surface gages } \\
\text { RTP=Recording } \\
\text { Trailer Park } \\
\text { ONl=Orientaion } \\
\text { to WP Not } \\
\text { Investigated }\end{array}$ \\
\hline PLATTE & U12k.01 & \begin{tabular}{|l} 
LLNL, Pre- \\
BANEBERRY
\end{tabular} & None & None & None & None & None & $\begin{array}{l}\text { Cree Field Ground Motion } \\
\text { Measurements (U)", V. E. } \\
\text { Wheeler/ R. G. Preston, } \\
\text { UOPBA 74-126, 8/21/74, }\end{array}$ & $\begin{array}{l}\text { Gage data not reported } \\
\text { by Sandia. }\end{array}$ & $\begin{array}{l}\text { Subsurface } 2 \text { GM } \\
(\text { ONI) gages } \\
\text { (Ref. UOPBA 74- } \\
126) \\
\end{array}$ \\
\hline POD-A & U2ck & $\begin{array}{l}\text { LLNL, Pre- } \\
\text { BANEBERRY }\end{array}$ & $\begin{array}{l}3 \text { Binders, No Hole } \\
\text { Ref. }\end{array}$ & $\begin{array}{l}\text { CD of Compressed } \\
\text { Raw \& Processed } \\
\text { Data }\end{array}$ & $\begin{array}{l}\text { Emplacement and } \\
\text { Stemming DWGs } \\
\text { Only. }\end{array}$ & None & None & Binder $\mathrm{N}$ & None & \\
\hline POD-B & U2ch & $\begin{array}{l}\text { LLNL, Pre- } \\
\text { BANEBERRY } \\
\end{array}$ & $\begin{array}{l}3 \text { Binders, No Hole } \\
\text { Ref. }\end{array}$ & $\begin{array}{l}\text { CD of Compressed } \\
\text { Raw \& Processed } \\
\text { Data }\end{array}$ & $\begin{array}{l}\text { See PUD rolder. } \\
\text { Emplacement and } \\
\text { Stemming DWGs } \\
\text { Only. }\end{array}$ & None & None & Binder $\mathrm{N}$ & None & \\
\hline POD-C & U2ci & $\begin{array}{l}\text { LLNL, Pre- } \\
\text { BANEBERRY } \\
\end{array}$ & $\begin{array}{l}3 \text { Binders, No Hole } \\
\text { Ref. }\end{array}$ & $\begin{array}{l}\text { CD of Compressed } \\
\text { Raw \& Processed } \\
\text { Data }\end{array}$ & $\begin{array}{l}\text { See POD Folder. } \\
\text { Emplacement and } \\
\text { Stemming DWGs } \\
\text { Only. }\end{array}$ & None & None & Binder N & None & \\
\hline POD-D & U2cj & $\begin{array}{l}\text { LLNL, Pre- } \\
\text { BANEBERRY }\end{array}$ & $\begin{array}{l}3 \text { Binders, No Hole } \\
\text { Ref. }\end{array}$ & $\begin{array}{l}\text { CD of Compressed } \\
\text { Raw \& Processed } \\
\text { Data }\end{array}$ & $\begin{array}{l}\text { See POD rolder. } \\
\text { Emplacement and } \\
\text { Stemming DWGs } \\
\text { Only. }\end{array}$ & None & None & Binder $\mathrm{N}$ & None & \\
\hline POLYGONUM & U2by & LLNL & 2 Binders & $\begin{array}{l}\text { CD of Compressed } \\
\text { Raw \& Processed } \\
\text { Data }\end{array}$ & 1 Folder & None & $\begin{array}{l}\text { Earth Strain } \\
\text { Cals., PDS Cals. }\end{array}$ & Binders $\mathrm{B}, \mathrm{H}, \mathrm{M}$ & None & \\
\hline POOL & U19p & LANL & None & None & None & None & Earth Strain Cals. & None & None & \\
\hline PORTMANTEAU & U2ax & LLNL & None & $\begin{array}{l}\text { CD of Compressed } \\
\text { Raw \& Processed } \\
\text { Data; } 1 \text { Engineering } \\
\text { Binder, }\end{array}$ & 1 Folder & None & \begin{tabular}{|l|} 
Earth Strain Cals. \\
; Pathfinder II . \\
Pathfinder CD of \\
Compressed Raw \\
$\&$ Processed \\
Data (V) \\
\end{tabular} & None & $\begin{array}{l}\text { "PORTMANTEAU and the } \\
\text { CARPETBAG Fault" }\end{array}$ & \\
\hline PORTOLA & U10bb & LLNL & 1 Binder & $\begin{array}{l}\text { CD of Compressed } \\
\text { Raw \& Processed } \\
\text { Data }\end{array}$ & 1 Folder & None & None & Binder B & None & \\
\hline
\end{tabular}


Ground Motion Data: Appendix 3B (John Rambo)

\begin{tabular}{|c|c|c|c|c|c|c|c|c|c|c|}
\hline This o & ides in the & DNT Containm & Program files. Pros & $\begin{array}{c}\text { DATA } \\
\begin{array}{c}\text { Later EG\&G } \\
\text { processed data and } \\
\text { reports }\end{array}\end{array}$ & $\begin{array}{c}\text { DATA } \\
- \text { Later data } \\
\text { processed at LLNL } \\
\text { by EG\&G }\end{array}$ & \begin{tabular}{|} 
6483, burkhard1@ @|| \\
DATA \\
Data Plots, \\
Surface, \\
Subsurface \\
Ground Motion, \\
Pressure/ \\
Radiation \\
LOS/Displ./ Misc. \\
Similar Items are \\
included in this \\
column.
\end{tabular} & $\begin{array}{c}\text { DATA } \\
\text { Ground Motion at } \\
\text { Distance From } \\
\text { SGZ. Geophone } \\
\text { plots (yellow). }\end{array}$ & Program Leader Gayle Pawl & $\begin{array}{c}\text { SUMMARY AND FINAL } \\
\text { REPORTS } \\
\text { CONF=Classified CFRD } \\
\begin{array}{c}\text { CDR=Containment Data } \\
\text { Report }\end{array}\end{array}$ & $\begin{array}{l}\text { oski@llnl.gov). } \\
\text { GAGE } \\
\text { LOCATIONS FOR } \\
\text { FREE SURFACE } \\
\text { AND FREE FIELD } \\
\text { DATA } \\
\text { RR=Round Robin } \\
\text { Surface gages } \\
\text { RTP=Recording } \\
\text { Trailer Park } \\
\text { ONl=Orientaion } \\
\text { to WP Not } \\
\text { Investigated }\end{array}$ \\
\hline PORTULACA & U2bv & LLNL & None & None & None & None & $\begin{array}{l}\text { Earth Strain Cals. } \\
\text {; Pathfinder II ; } \\
\text { PDS Cals. }\end{array}$ & None & None & \\
\hline POTRERO & U2eb & LLNL & 2 Binders & None & 1 Folder & None & None & Binders $\mathrm{B}, \mathrm{H}, \mathrm{K}$ & None & \\
\hline PURSE & U2Ov & $\begin{array}{l}\text { LLNL, Pre- } \\
\text { BANEBERRY }\end{array}$ & None & None & None & None & $\begin{array}{l}3 \text { Geophone Rolls } \\
\text { (Yellow) }\end{array}$ & None & None & \\
\hline QUARGEL & $\mathrm{U} 2 \mathrm{fb}$ & LLNL & None & \begin{tabular}{|l|} 
CD of Compressed \\
Raw \& Processed \\
Data
\end{tabular} & None & $\begin{array}{l}1 \text { CLIPER Printout } \\
\text { (Blue) }\end{array}$ & Earth Strain Cals. & None & None & \\
\hline QUESO & U10bf & LLNL & None & \begin{tabular}{|l|} 
CD of Compressed \\
Raw \& Processed \\
Data; CD of ASCII \\
Processed Data; 1 \\
Binder
\end{tabular} & 2 Folders & $\begin{array}{l}2 \text { Ground Motion } \\
\text { Rolls (Blue) }\end{array}$ & None & $\begin{array}{l}\text { Binder T (CLIPER/EXCOR), } \\
\text { Binder S (SMIDS Collapse } \\
\text { Signals) }\end{array}$ & $\begin{array}{l}\text { Draft Report "Strong } \\
\text { Motion from the Event } \\
\text { QUESO" ; UCRL-ID- } \\
121259 \text { (CDR) }\end{array}$ & $\begin{array}{l}\text { Surface, Horiz. } \\
\text { Dist. 50' (Ref. } \\
\text { CDR): } \\
\text { Subsurface, Free } \\
\text { field gages, } 3 \\
\text { vertical offset } \\
\text { GM gages, } 2 \\
\text { vertical offset } \\
\text { stress gages, } 4 \\
\text { GM gages in } \\
\text { Plugs (Ref. CDR) }\end{array}$ \\
\hline RACOON & U3aj-S & $\begin{array}{l}\text { LANL, Pre- } \\
\text { BANEBERRY } \\
\end{array}$ & None & None & None & None & None & $\begin{array}{l}\text { LFKD report "reak surtace } \\
\text { Velocity from Nuclear } \\
\text { Explosions (U)", V. E. } \\
\text { Wheeler, UOPBA 73-44, } \\
3 / 16 / 73 \text {, }\end{array}$ & None & $\begin{array}{l}\text { Surface, Hor. } \\
\text { dist. (NI) (Ref. } \\
\text { UOPBA 73-44) }\end{array}$ \\
\hline
\end{tabular}


Ground Motion Data: Appendix 3B (John Rambo)

\begin{tabular}{|c|c|c|c|c|c|c|c|c|c|c|}
\hline (1) & HOLE & 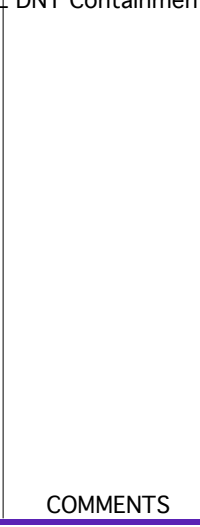 & $\begin{array}{c}\text { DATA } \\
\text { Early LLNL } \\
\text { processed data } \\
\text { and reports }\end{array}$ & $\begin{array}{c}\text { DATA } \\
\begin{array}{c}\text { Later EG\&G } \\
\text { processed data and } \\
\text { reports }\end{array}\end{array}$ & $\begin{array}{c}\text { DATA } \\
-1 \text { Later data } \\
\begin{array}{c}\text { processed at LLNL } \\
\text { by EG\&G }\end{array}\end{array}$ & \begin{tabular}{|c} 
DATA \\
-_-_-_-_- \\
Data Plots, \\
Surface, \\
Subsurface \\
Ground Motion, \\
Pressure/ \\
Radiation \\
LOS/Displ./ Misc. \\
Similar Items are \\
included in this \\
column.
\end{tabular} & $\begin{array}{c}\text { DATA } \\
\text { Ground Motion at } \\
\text { Distance From } \\
\text { SGZ. Geophone } \\
\text { plots (yellow). }\end{array}$ & EVENT COMPARISONS & $\begin{array}{c}\text { SUMMARY AND FINAL } \\
\text { REPORTS } \\
\text { CONF=Classified CFRD } \\
\text { CDR=Containment Data } \\
\text { Report }\end{array}$ & $\begin{array}{c}\text { GAGE } \\
\text { LOCATIONS FOR } \\
\text { FREE SURFACE } \\
\text { AND FREE FIELD } \\
\text { DATA } \\
\text { RR=Round Robin } \\
\text { Surface gages } \\
\text { RTP=Recording } \\
\text { Trailer Park } \\
\text { ONI=Orientaion } \\
\text { to WP Not } \\
\text { Investigated }\end{array}$ \\
\hline RAINIER & U12b & $\begin{array}{l}\text { LLNL, Pre- } \\
\text { BANEBERRY }\end{array}$ & None & None & None & None & (1) & $\begin{array}{l}\text { Field Peak Radial Stresses } \\
\text { from Underground Nuclear } \\
\text { Explosiona in Five Explosion } \\
\text { Media (U)", V. E. Wheeler/ } \\
\text { R. G. Preston, UOPKG 66- } \\
80,12, / 7 / 66, \text {. Free-Field } \\
\text { Peak Particle Velocities and } \\
\text { Stresses fron Underground } \\
\text { Nuclear Explosions in a } \\
\text { LONGSHOT - type } \\
\text { Environment, R. G. Preston, } \\
\text { UOPKG 67-18, 4/26/67. } \\
\text { CFRD report "Peak Surface } \\
\text { Velocity from Nuclear } \\
\text { Explosions (U)", V. E. } \\
\text { Wheeler, UOPBA 73-44, } \\
\text { 3/16/73, CFRD report } \\
\text { "Summary of Free Field } \\
\text { Ground Motion } \\
\text { Measurements (U)", V. E. } \\
\text { Wheeler/ R. G. Preston, } \\
\text { UOPBA 74-126, 8/21/74, } \\
\text {. CFRD report "Ground } \\
\text { Shock Predictions for } \\
\text { Underground Nuclear } \\
\text { Explosions in Rainier Mesa } \\
\text { (U)", L. F. Ingram, J. L. } \\
\text { Drake, DNA-TR-88-14, } \\
\text { 10/23/87, . }\end{array}$ & $\begin{array}{l} \\
\\
\\
\\
\text { CFRD report "Ground } \\
\text { Shock Predictions for } \\
\text { Underground Nuclear } \\
\text { Explosions in Rainier Mesa } \\
\text { (U)", L. F. Ingram, J. L. } \\
\text { Drake, DNA-TR-88-14, } \\
10 / 23 / 87 . \text { Unclassified } \\
\text { report "Free-Field Ground } \\
\text { Motion Induced by } \\
\text { Underground Explosions", } \\
\text { W. R. Perret, and R. C. } \\
\text { Bass, SAND74-0252, } \\
\text { Sandia Laboratories, } \\
11 / 72 . \text { Perret, POR-1803. } \\
\text { Also see Sandia Reports } \\
\text { WT-1529 and WT-1528. }\end{array}$ & \begin{tabular}{|l} 
\\
\\
Surface, Hor. \\
dist. (NI) (Ref. \\
UOPBA 73-44); \\
Subsurface, 8 \\
shot level gages, \\
9 verticle gages \\
(Ref. UOPBA 74- \\
126), 4 Sandia \\
GM gages (Ref. \\
DNA-TR-88-14)
\end{tabular} \\
\hline REBLOCHON & U2en & LLNL & None & $\begin{array}{l}\text { CD of Compressed } \\
\text { Raw \& Processed } \\
\text { Data }\end{array}$ & None & None & None & Binder T (CLIPER/EXCOR) & None & \\
\hline RED HOT & U12g & $\begin{array}{l}\text { LANL/DOD, Pre- } \\
\text { BANEBERRY }\end{array}$ & None & None & None & None & None & $\begin{array}{l}\text { Velocity from Nuclear } \\
\text { Explosions (U)", V. E. } \\
\text { Wheeler, UOPBA 73-44, } \\
3 / 16 / 73 \text {, }\end{array}$ & None & $\begin{array}{l}\text { Surface, Hor. } \\
\text { dist. (NI) (Ref. } \\
\text { UOPBA 73-44) }\end{array}$ \\
\hline REDMUD & U7ab & LANL & None & None & None & None & Earth Strain Cals. & None & None & \\
\hline
\end{tabular}


Ground Motion Data: Appendix 3B (John Rambo)

\begin{tabular}{|c|c|c|c|c|c|c|c|c|c|c|}
\hline 更 & HOLE & COMMENTS & $\begin{array}{c}\text { DATA } \\
\text { Early LLNL } \\
\text { processed data } \\
\text { and reports } \\
\end{array}$ & $\begin{array}{c}\text { DATA } \\
\begin{array}{c}\text { Later EG\&G } \\
\text { processed data and } \\
\text { reports }\end{array} \\
\end{array}$ & \begin{tabular}{|c|} 
DATA \\
Later data \\
processed at LLNL \\
by EG\&G
\end{tabular} & \begin{tabular}{|c|} 
DATA \\
Data Plots, \\
Surface, \\
Subsurface \\
Ground Motion, \\
Pressure/ \\
Radiation \\
LOS/Displ./ Misc. \\
Similar Items are \\
included in this \\
column.
\end{tabular} & $\begin{array}{c}\text { DATA } \\
\text { Ground Motion at } \\
\text { Distance From } \\
\text { SGZ. Geophone } \\
\text { plots (yellow). }\end{array}$ & 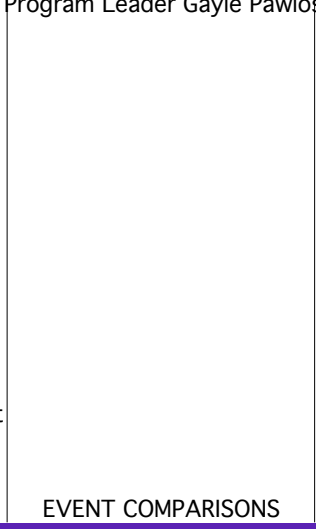 & $\begin{array}{c}\text { SUMMARY AND FINAL } \\
\text { REPORTS } \\
\text { CONF=Classified CFRD } \\
\text { CDR=Containment Data } \\
\text { Report }\end{array}$ & $\begin{array}{c}\text { GSI@ IInl.gov). } \\
\text { GAGE } \\
\text { LOCATIONS FOR } \\
\text { FREE SURFACE } \\
\text { AND FREE FIELD } \\
\text { DATA } \\
\text { RR=Round Robin } \\
\text { Surface gages } \\
\text { RTP=Recording } \\
\text { Trailer Park } \\
\text { ONI=Orientaion } \\
\text { to WP Not } \\
\text { Investigated }\end{array}$ \\
\hline REX & U2Oh & $\begin{array}{l}\text { LLNL, Pre- } \\
\text { BANEBERRY } \\
\end{array}$ & None & None & None & None & \begin{tabular}{|l|}
1 Wide \\
Geophone Roll \\
(Yellow)
\end{tabular} & None & None & \\
\hline RHYOLITE & U2ey & LLNL & None & $\begin{array}{l}\text { CD of Compressed } \\
\text { Raw \& Processed } \\
\text { Data; CD of ASCII } \\
\text { Processed Data; } 1 \\
\text { Binder } \\
\end{array}$ & 2 Folders & None & $\begin{array}{l}1 \text { Geophone Roll } \\
\text { (Yellow) }\end{array}$ & $\begin{array}{l}\text { Binder W, } 2 \text { Presentation } \\
\text { Binders }\end{array}$ & MISC 4642 (CDR) & $\begin{array}{l}\text { Dist. 50' (Ref. } \\
\text { CDR): } \\
\text { Subsurface, No } \\
\text { free field gages, } \\
5 \text { GM gages in } \\
\text { Plugs (Ref. CDR) }\end{array}$ \\
\hline RINGTAIL & U3ak & $\begin{array}{l}\text { LANL, Pre- } \\
\text { BANEBERRY } \\
\end{array}$ & None & 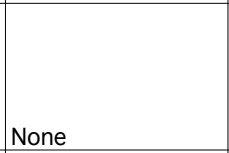 & None & None & None & $\begin{array}{l}\text { CFKU report "reak surtace } \\
\text { Velocity from Nuclear } \\
\text { Explosions }(\mathrm{U}) ", \text { V. E. } \\
\text { Wheeler, UOPBA } 73-44, \\
3 / 16 / 73 \text {, }\end{array}$ & None & $\begin{array}{l}\text { Surface, Hor. } \\
\text { dist. (NI) (Ref. } \\
\text { UOPBA 73-44) }\end{array}$ \\
\hline RIO BLANCO & OCO RBL & LLNL & 1 Binder & $\begin{array}{l}\text { CD of Compressed } \\
\text { Raw \& Processed } \\
\text { Data }\end{array}$ & None & None & None & None & $\begin{array}{l}\text { "The RIO BLANCO } \\
\text { Experiment: Subsurface } \\
\text { and Surface Effects and } \\
\text { Measurements" }\end{array}$ & \\
\hline RIOLA & U2eq & LLNL & None & $\begin{array}{l}\text { CD of Compressed } \\
\text { Raw \& Processed } \\
\text { Data }\end{array}$ & 1 Folder & None & None & 1 Presentation Binder & $\begin{array}{l}\text { "RIOLA Release Repost" } \\
\text { UCRL-53437 }\end{array}$ & \\
\hline RIVOLI & U2eg & LLNL & 2 Binders & $\begin{array}{l}\text { CD of Compressed } \\
\text { Raw \& Processed } \\
\text { Data }\end{array}$ & 1 Folder & $\begin{array}{l}1 \text { Ground Motion } \\
\text { Roll (Blue) }\end{array}$ & Earth Strain Cals. & 3 Presentation Binders & 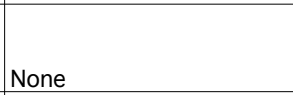 & \\
\hline ROMANO & U2ex & LLNL & None & None & 1 Folder & None & None & None & None & \\
\hline ROQUEFORT & U4as & LLNL & None & $\begin{array}{l}\text { CD of Compressed } \\
\text { Raw \& Processed } \\
\text { Data; CD of ASCII } \\
\text { Processed Data; } 1 \\
\text { Binder }\end{array}$ & 2 Folders & \begin{tabular}{|l|}
2 Pres./ Radiation \\
Printout Rolls \\
(Red)
\end{tabular} & None & $\begin{array}{l}\text { Binder X, Binder U (Peak } \\
\text { Accelleration of Trailers), } \\
10 \text { Presentation Binders }\end{array}$ & UCRL-ID-1 19552 (CDR) & $\begin{array}{l}\text { Dist. 50', } \\
\text { 689',1378', } \\
\text { 2067', RTP (Ref. } \\
\text { CDR): } \\
\text { Subsurface, No } \\
\text { free field gages, } \\
2 \text { GM gages in } \\
\text { Plugs (Ref. CDR) }\end{array}$ \\
\hline RUDDER & U7aj S & LANL & None & None & None & None & Earth Strain Cals. & None & None & \\
\hline
\end{tabular}


Ground Motion Data: Appendix 3B (John Rambo)

\begin{tabular}{|c|c|c|c|c|c|c|c|c|c|c|}
\hline This c & ides in the & DNT Containme & $\begin{array}{c}\text { DATA } \\
\text { Early LLNL } \\
\text { processed data } \\
\text { and reports }\end{array}$ & $\begin{array}{c}\text { DATA } \\
\begin{array}{c}\text { Later EG\&G } \\
\text { processed data and } \\
\text { reports }\end{array}\end{array}$ & $\begin{array}{c}\text { DATA } \\
- \text { Later data } \\
\begin{array}{c}\text { processed at LLNL } \\
\text { by EG\&G }\end{array}\end{array}$ & \begin{tabular}{|c}
483, burkhard1 @lli \\
DATA \\
Data Plots, \\
Surface, \\
Subsurface \\
Ground Motion, \\
Pressure/ \\
Radiation \\
LOS/Displ./ Misc. \\
Similar Items are \\
included in this \\
column.
\end{tabular} & \begin{tabular}{|c|} 
DATA \\
Ground Motion at \\
Distance From \\
SGZ. Geophone \\
plots (yellow).
\end{tabular} & Program Leader Gayle Paw & $\begin{array}{l}\text { SUMMARY AND FINAL } \\
\text { REPORTS } \\
\text { CONF=Classified CFRD } \\
\text { CDR=Containment Data } \\
\text { Report }\end{array}$ & $\begin{array}{c}\text { oski@llnl.gov). } \\
\text { GAGE } \\
\text { LOCATIONS FOR } \\
\text { FREE SURFACE } \\
\text { AND FREE FIELD } \\
\text { DATA } \\
\text { RR=Round Robin } \\
\text { Surface gages } \\
\text { RTP=Recording } \\
\text { Trailer Park } \\
\text { ONI=Orientaion } \\
\text { to WP Not } \\
\text { Investigated }\end{array}$ \\
\hline SALMON & OMS LAM & $\begin{array}{l}\text { LLNL/DOD, Pre- } \\
\text { BANEBERRY, } \\
\text { Hattiesburg MI, } \\
\text { WP in salt }\end{array}$ & 1 Binder & None & None & None & None & $\begin{array}{l}\text { Velocity from Nuclear } \\
\text { Explosions (U)", V. E. } \\
\text { Wheeler, UOPBA 73-44, } \\
3 / 16 / 73, \text {. CFRD report } \\
\text { "Summary of Free Field } \\
\text { Ground Motion } \\
\text { Measurements (U)", V. E. } \\
\text { Wheeler/ R. G. Preston, } \\
\text { UOPBA 74-126, 8/21/74, }\end{array}$ & $\begin{array}{l}\text { "Free-Field Particle Motion } \\
\text { from a Nuclear Explosion } \\
\text { in Salt, Part I \& Part II" ; } \\
\text { "Free Field Motion Near a } \\
\text { Nuclear Explosion in Salt: } \\
\text { Project SALMON" . Also } \\
\text { see Sandia report VUF } \\
3012 \text { and SRI report VUF } \\
3013 .\end{array}$ & $\begin{array}{l}\text { dist. (NI) (Ref. } \\
\text { UOPBA 73-44); } \\
\text { Subsurface, 4 } \\
\text { shot level GM } \\
\text { gages, } 15 \text { offset } \\
\text { vertical GM } \\
\text { gages, 13 } \\
\text { vertical GM } \\
\text { gages (Ref. } \\
\text { UOPBA 74-126) } \\
\end{array}$ \\
\hline SALUT & U20ak & LLNL & None & $\begin{array}{l}\text { CD of Compressed } \\
\text { Raw \& Processed } \\
\text { Data; CD of ASCII } \\
\text { Processed Data; } 1 \\
\text { Binder }\end{array}$ & 2 Folders & \begin{tabular}{|l|}
4 Ground Motion \\
Rolls (Blue), 2 \\
Rolls of Pres./ \\
Radiation Traces \\
(Red)
\end{tabular} & None & $\begin{array}{l}\text { Binder X, Binder U (Peak } \\
\text { Accelleration of Trailers), } \\
\text { Binder T (CLIPER/EXCOR), } \\
\text { Binder S (SMIDS Collapse } \\
\text { Signals), } 5 \text { Presentation } \\
\text { Binders }\end{array}$ & UCRL-ID-121263 (CDR) & $\begin{array}{l}\text { Surface, Horiz. } \\
\text { Dist. 50', 1002', } \\
2004 ', 3000^{\prime} \\
\text { (Ref. CDR): } \\
\text { Subsurface, No } \\
\text { free field gages, } \\
3 \text { GM gages in } \\
\text { Plugs (Ref. CDR) }\end{array}$ \\
\hline SANDREEF & U7aq & LANL & None & None & None & None & Earth Strain Cals. & None & None & \\
\hline SAPPHO & U2dh 2 & LLNL & 1 Binder & $\begin{array}{l}\text { CD of Compressed } \\
\text { Raw \& Processed } \\
\text { Data }\end{array}$ & 1 Folder & None & $\begin{array}{l}\text { "Round Robin } \\
\text { Program } \\
\text { SAPPHO Event } \\
\text { (U)", W. R. } \\
\text { Perret, Sandia } \\
\text { UOPBA 72-43, } \\
\text { 4/14/72 (V). }\end{array}$ & $\begin{array}{l}\text { Binders B, H, J. CFRD } \\
\text { report "Peak Surface } \\
\text { Velocity from Nuclear } \\
\text { Explosions (U)", V. E. } \\
\text { Wheeler, UOPBA 73-44, } \\
\text { 3/16/73, }\end{array}$ & None & $\begin{array}{l}\text { Surface (Ref. } \\
\text { RR) Horiz., 50', } \\
324^{\prime}, 325^{\prime}, 325^{\prime}\end{array}$ \\
\hline SATZ & U2do & LLNL & None & $\begin{array}{l}\text { CD of Compressed } \\
\text { Raw \& Processed } \\
\text { Data }\end{array}$ & None & None & Earth Strain Cals. & $\begin{array}{l}\text { Binder T (CLIPER/EXCOR), } \\
1 \text { Presentation Binder }\end{array}$ & None & \\
\hline SCANTLING & U $4 \mathrm{~h}$ & LANL & None & None & None & None & $\begin{array}{l}\text { Earth Strain Cals. } \\
\text {. Pathfinder CD } \\
\text { of Compressed } \\
\text { Raw \& Processed } \\
\text { Data }(V)\end{array}$ & None & None & \\
\hline
\end{tabular}


Ground Motion Data: Appendix 3B (John Rambo)

\begin{tabular}{|c|c|c|c|c|c|c|c|c|c|c|}
\hline This da & Ides in the & DNI Containme & $\begin{array}{c}\text { DATA } \\
\text { Early LLNL } \\
\text { processed data } \\
\text { and reports }\end{array}$ & $\begin{array}{c}\text { DATA } \\
\text { Later EG\&G } \\
\begin{array}{c}\text { processed data and } \\
\text { reports }\end{array} \\
\end{array}$ & $\begin{array}{c}\text { DATA } \\
\text { Later data } \\
\begin{array}{c}\text { processed at LLNL } \\
\text { by EG\&G }\end{array}\end{array}$ & \begin{tabular}{|c} 
DATA \\
Data Plots, \\
Surface, \\
Subsurface \\
Ground Motion, \\
Pressure/ \\
Radiation \\
LOS/Displ./ Misc. \\
Similar Items are \\
included in this \\
column.
\end{tabular} & \begin{tabular}{|c} 
DATA \\
Ground Motion at \\
Distance From \\
SGZ. Geophone \\
plots (yellow).
\end{tabular} & 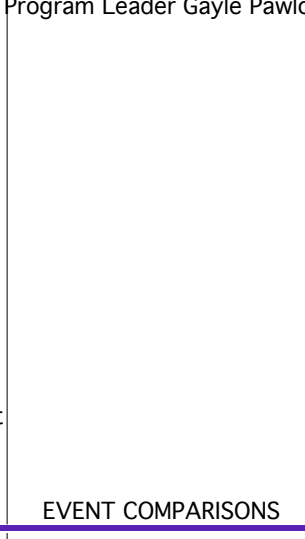 & $\begin{array}{c}\text { SUMMARY AND FINAL } \\
\text { REPORTS } \\
\text { CONF=Classified CFRD } \\
\text { CDR=Containment Data } \\
\text { Report }\end{array}$ & $\begin{array}{c}\text { Gsk@@Inl.gov). } \\
\text { GAGE } \\
\text { LOCATIONS FOR } \\
\text { FREE SURFACE } \\
\text { AND FREE FIELD } \\
\text { DATA } \\
\text { RR=Round Robin } \\
\text { Surface gages } \\
\text { RTP=Recording } \\
\text { Trailer Park } \\
\text { ONI=Orientaion } \\
\text { to WP Not } \\
\text { Investigated }\end{array}$ \\
\hline SCHELLBOURNE & U2gf & LLNL & None & $\begin{array}{l}\text { CD of Compressed } \\
\text { Raw \& Processed } \\
\text { Data; CD of ASCII } \\
\text { Processed Data; } 1 \\
\text { Binder }\end{array}$ & 1 Folder & None & None & $\begin{array}{l}\text { Binder W, } 1 \text { Presentation } \\
\text { Binder }\end{array}$ & MISC 4688 (CDR) & $\begin{array}{l}\text { Dist. 50', 900', } \\
1800 ' \text { (Ref. } \\
\text { CDR): } \\
\text { Subsurface, No } \\
\text { free field gages, } \\
1 \text { GM gage in } \\
\text { Plug (Ref. CDR) }\end{array}$ \\
\hline SCHOONER & U20u & $\begin{array}{l}\text { LLNL, Pre- } \\
\text { BANEBERRY } \\
\end{array}$ & None & $\begin{array}{l}\text { CD of Compressed } \\
\text { Raw \& Processed } \\
\text { Data }\end{array}$ & None & None & None & None & None & \\
\hline $\mathrm{SCOTCH}$ & U19a S & $\begin{array}{l}\text { LANL Pre- } \\
\text { BANEBERRY } \\
\end{array}$ & 1 Binder & None & None & None & None & $\begin{array}{l}\text { Velocity from Nuclear } \\
\text { Wheeler, UOPBA } 73-44 \text {, } \\
3 / 16 / 73 \text {, }\end{array}$ & None & $\begin{array}{l}\text { Surface, Hor. } \\
\text { dist. (NI) (Ref. } \\
\text { UOPBA 73-44) }\end{array}$ \\
\hline SCROLL & U19n & $\begin{array}{l}\text { LLNL, Pre- } \\
\text { BANEBERRY }\end{array}$ & None & None & None & None & \begin{tabular}{|l|} 
CFRD report \\
"Ground Motion \\
Measurements at \\
the LRL SCROLL \\
Site from the \\
LASL STINGER \\
Event (U)", R. T. \\
Stearns/J. T. \\
Rambo, Nevada: \\
LRL Memo, \\
4/22/68, (V) \\
\end{tabular} & None & None & \\
\hline SEAFOAM & U2ea & LLNL & 1 Binder & $\begin{array}{l}\text { CD of Compressed } \\
\text { Raw \& Processed } \\
\text { Data }\end{array}$ & 1 Folder & None & None & Binders $\mathrm{B}, \mathrm{H}$ & None & \\
\hline SEAMOUNT & U3kp & LANL & None & None & None & None & Earth Strain Cals. & None & None & \\
\hline
\end{tabular}


Ground Motion Data: Appendix 3B (John Rambo)

\begin{tabular}{|c|c|c|c|c|c|c|c|c|c|c|}
\hline This 0 & a to & DNT Containment & Program niles. Pros & $\begin{array}{c}\text { DATA } \\
\text { Later EG\&G } \\
\begin{array}{c}\text { processed data and } \\
\text { reports }\end{array}\end{array}$ & $\begin{array}{c}\text { DATA } \\
\text { Later data } \\
\begin{array}{c}\text { processed at LLNL } \\
\text { by EG\&G }\end{array}\end{array}$ & \begin{tabular}{|c} 
DATA \\
Data Plots, \\
Surface, \\
Subsurface \\
Ground Motion, \\
Pressure/ \\
Radiation \\
LOS/Displ./ Misc. \\
Similar Items are \\
included in this \\
column.
\end{tabular} & \begin{tabular}{|c} 
DATA \\
Ground Motion at \\
Distance From \\
SGZ. Geophone \\
plots (yellow).
\end{tabular} & 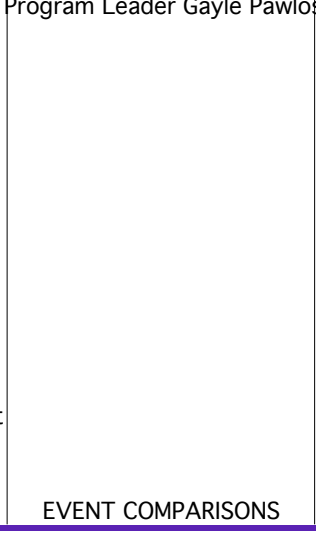 & $\begin{array}{c}\text { SUMMARY AND FINAL } \\
\text { REPORTS } \\
\text { CONF=Classified CFRD } \\
\text { CDR=Containment Data } \\
\text { Report }\end{array}$ & $\begin{array}{l}\text { GAGE } \\
\text { LOCATIONS FOR } \\
\text { FREE SURFACE } \\
\text { AND FREE FIELD } \\
\text { DATA } \\
\text { RR=Round Robin } \\
\text { Surface gages } \\
\text { RTP=Recording } \\
\text { Trailer Park } \\
\text { ONI=Orientaion } \\
\text { to WP Not } \\
\text { Investigated }\end{array}$ \\
\hline SECO & U8I & LLNL & None & $\begin{array}{l}\text { CD of Compressed } \\
\text { Raw \& Processed } \\
\text { Data; CD of ASCII } \\
\text { Processed Data; } 1 \\
\text { Binder }\end{array}$ & 1 Folder & $\begin{array}{l}2 \text { Ground Motion } \\
\text { Rolls (Blue) }\end{array}$ & None & None & $\begin{array}{l}\text { Draft Report "Motion of } \\
\text { the Emplacement Hole } \\
\text { and on the Ground } \\
\text { Surface, SECO Event" ; } \\
\text { "Motion Measured on the } \\
\text { SECO EVENT" UOPKL 82- } \\
84 \text { (Conf. FRD) ; UCRL-ID- } \\
127715 \text { (CDR) }\end{array}$ & $\begin{array}{l}\text { Surface, Horiz. } \\
\text { Dist. 50', } 14 \\
\text { other surface } \\
\text { gages, see } \\
\text { report for horiz. } \\
\text { Locations. (Ref. } \\
\text { CDR): } \\
\text { Subsurface, No } \\
\text { free field gages, } \\
4 \text { GM gages in } \\
\text { Plugs (Ref. CDR) }\end{array}$ \\
\hline SEDAN & U10h & $\begin{array}{l}\text { Cratering } \\
\text { Experiment, LLNL, } \\
\text { Pre-BANEBERRY }\end{array}$ & None & None & None & None & None & None & $\begin{array}{l}\text { Effects from a High Yield } \\
\text { Nuclear Cratering } \\
\text { Experiment in Desert } \\
\text { Alluvium" }\end{array}$ & \\
\hline SERENA & U20an & LLNL & None & & 1 Folder & None & None & $\begin{array}{l}\text { Binder T (CLIPER/EXCOR), } \\
3 \text { Presentation Binders }\end{array}$ & None & \\
\hline SERPA & U19ai & LLNL & None & $\begin{array}{l}\text { CD of Compressed } \\
\text { Raw \& Processed } \\
\text { Data }\end{array}$ & 1 Folder & None & Earth Strain Cals. & None & None & \\
\hline SHOAL & ONV & 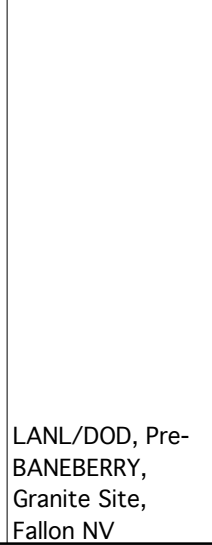 & None & None & None & None & None & $\begin{array}{l}\text { CFRD report "Scaled Free- } \\
\text { Field Peak Radial Stresses } \\
\text { from Underground Nuclear } \\
\text { Explosiona in Five Explosion } \\
\text { Media (U)", V. E. Wheeler/ } \\
\text { R. G. Preston, UOPKG 66- } \\
80,12, / 7 / 66, \text { CFRD } \\
\text { report "Peak Surface } \\
\text { Velocity from Nuclear } \\
\text { Explosions (U)", V. E. } \\
\text { Wheeler, UOPBA 73-44, } \\
\text { 3/16/73, . CFRD report } \\
\text { "Summary of Free Field } \\
\text { Ground Motion } \\
\text { Measurements (U)", V. E. } \\
\text { Wheeler/ R. G. Preston, } \\
\text { UOPBA 74-126, 8/21/74, } \\
\end{array}$ & $\begin{array}{l}\text { } \\
\\
2 \text { reports "Surface } \\
\text { Response Spectra Project } \\
\text { SHOAL" . \& Sandia report, } \\
\text { VUF-2001, Weart }\end{array}$ & $\begin{array}{l}\text { Surface, Hor. } \\
\text { dist. (NI) (Ref. } \\
\text { UOPBA 73-44); } \\
\text { Subsurface, } 7 \\
\text { shot level GM } \\
\text { gages, } 5 \text { verticle } \\
\text { GM gages (Ref. } \\
\text { UOPBA 74-126) } \\
\end{array}$ \\
\hline
\end{tabular}


Ground Motion Data: Appendix 3B (John Rambo)

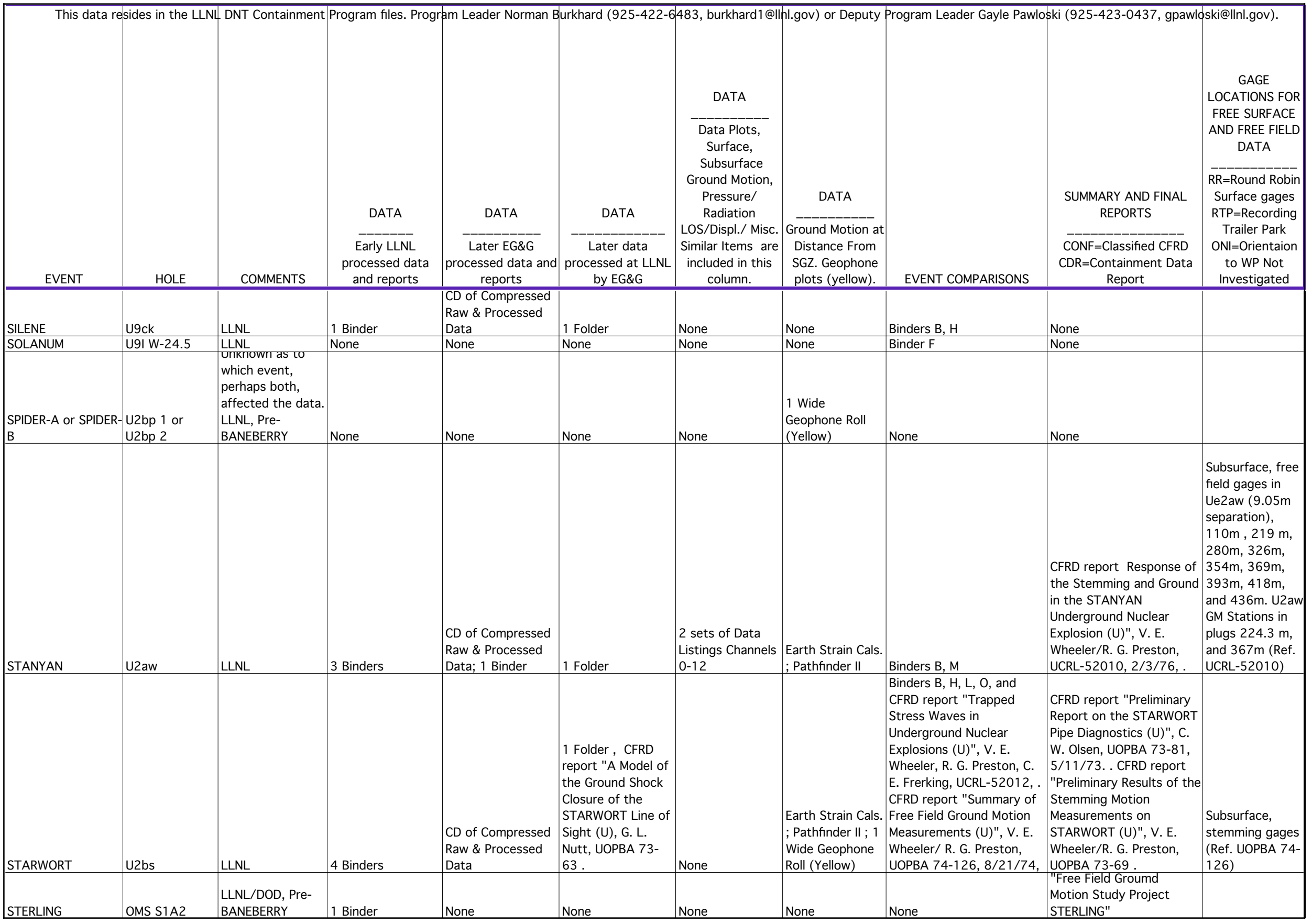


Ground Motion Data: Appendix 3B (John Rambo)

\begin{tabular}{|c|c|c|c|c|c|c|c|c|c|c|}
\hline This c & ides in th & DNT Containm & Program files. Pros & $\begin{array}{c}\text { DATA } \\
- \text { Later EG\&G } \\
\begin{array}{c}\text { processed data and } \\
\text { reports }\end{array}\end{array}$ & $\begin{array}{c}\text { DATA } \\
\text { Later data } \\
\text { processed at LLNL } \\
\text { by EG\&G }\end{array}$ & $\begin{array}{c}\text { DATA } \\
\text { Data Plots, } \\
\text { Surface, } \\
\text { Subsurface } \\
\text { Ground Motion, } \\
\text { Pressure/ } \\
\text { Radiation } \\
\text { LOS/Displ./ Misc. } \\
\text { Similar Items are } \\
\text { included in this } \\
\text { column. }\end{array}$ & $\begin{array}{l}\text { DATA } \\
\text { Ground Motion at } \\
\text { Distance From } \\
\text { SGz. Geophone } \\
\text { plots (yellow). }\end{array}$ & to & $\begin{array}{c}\text { SUI }(925-423-0437, \mathrm{gpawl} \\
\text { SUMMARY AND FINAL } \\
\text { REPORTS } \\
\text { CONF=Classified CFRD } \\
\text { CDR=Containment Data } \\
\text { Report }\end{array}$ & $\begin{array}{l}\text { Gki@llnl.gov). } \\
\text { GAGE } \\
\text { LOCATIONS FOR } \\
\text { FREE SURFACE } \\
\text { AND FREE FIELD } \\
\text { DATA } \\
\text { RR=Round Robin } \\
\text { Surface gages } \\
\text { RTP=Recording } \\
\text { Trailer Park } \\
\text { ONI=Orientaion } \\
\text { to WP Not } \\
\text { Investigated }\end{array}$ \\
\hline STILTON & U20p & LLNL & None & None & None & None & Earth Strain Cals. & None & None & \\
\hline STINGER & U191 & $\begin{array}{l}\text { LANL, Pre- } \\
\text { BANEBERRY }\end{array}$ & None & None & None & None & $\begin{array}{l}\text { CFRD report } \\
\text { "Ground Motion } \\
\text { Measurements at } \\
\text { the LRL SCROLL } \\
\text { Site from the } \\
\text { LASL STINGER } \\
\text { Event }(U) ", \text { R. T. } \\
\text { Stearns/J. T. } \\
\text { Rambo, Nevada: } \\
\text { LRL Memo, } \\
\text { 4/22/68, (V) } \\
\end{array}$ & None & None & \\
\hline STOAT & U3ap & $\begin{array}{l}\text { LANL, Pre- } \\
\text { BANEBERRY }\end{array}$ & None & None & None & None & & $\begin{array}{l}\text { CFRD report "Peak surface } \\
\text { Velocity from Nuclear } \\
\text { Explosions }(U) ", \text { V. E. } \\
\text { Wheeler, UOPBA 73-44, } \\
3 / 16 / 73 \text {, }\end{array}$ & None & $\begin{array}{l}\text { Surface, Hor. } \\
\text { dist. (NI) (Ref. } \\
\text { UOPBA 73-44) }\end{array}$ \\
\hline STODDARD & $\mathrm{U} 2 \mathrm{~cm} \mathrm{~S}$ & $\begin{array}{l}\text { LLNL, Pre- } \\
\text { BANEBERRY }\end{array}$ & None & None & None & None & $\begin{array}{l}2 \text { Geophone Rolls } \\
\text { (in boxes) } \\
\text { (Yellow) }\end{array}$ & 1 Presentation Binder & None & \\
\hline SUTTER & U2bw & LLNL & 2 Binders & $\begin{array}{l}\text { CD of Compressed } \\
\text { Raw \& Processed } \\
\text { Data }\end{array}$ & 1 Folder & None & None & 1 Presentation Binder & None & \\
\hline TAFI & U20ae & LLNL & None & $\begin{array}{l}\text { CD of Compressed } \\
\text { Raw \& Processed } \\
\text { Data }\end{array}$ & 1 Folder & None & None & None & None & \\
\hline TANYA & U2dt & $\begin{array}{l}\text { LLNL, Pre- } \\
\text { BANEBERRY }\end{array}$ & None & None & None & None & $\begin{array}{l}3 \text { Geophone Rolls } \\
\text { (Yellow) }\end{array}$ & None & None & \\
\hline TAJIQUE & U7aa & LANL & None & None & None & None & $\begin{array}{l}\text { "Round Robin } \\
\text { Program } \\
\text { TAJIQUE Event } \\
\text { (U)", W. R. } \\
\text { Perret, Sandia } \\
\text { UOPBA 72-80, } \\
\text { 7/17/72 (V). }\end{array}$ & $\begin{array}{l}\text { CFRD report "Peak Surface } \\
\text { Velocity from Nuclear } \\
\text { Explosions (U)", V. E. } \\
\text { Wheeler, UOPBA 73-44, } \\
3 / 16 / 73\end{array}$ & None & $\begin{array}{l}\text { Surface (Ref. } \\
\text { RR) Horiz., 50', } \\
550^{\prime}, 550^{\prime}, 551^{\prime}\end{array}$ \\
\hline
\end{tabular}


Ground Motion Data: Appendix 3B (John Rambo)

\begin{tabular}{|c|c|c|c|c|c|c|c|c|c|c|}
\hline This c & ides in th & DNT Containment & $\begin{array}{c}\text { DATA } \\
\text { Early LLNL } \\
\text { processed data } \\
\text { and reports }\end{array}$ & $\begin{array}{c}\text { DATA } \\
\begin{array}{c}\text { Later EG\&G } \\
\text { processed data and } \\
\text { reports }\end{array} \\
\end{array}$ & \begin{tabular}{|c|} 
DATA \\
Later data \\
processed at LLNL \\
by EG\&G
\end{tabular} & \begin{tabular}{|c|} 
DATA \\
Data Plots, \\
Surface, \\
Subsurface \\
Ground Motion, \\
Pressure/ \\
Radiation \\
LOS/Displ./ Misc. \\
Similar Items are \\
included in this \\
column. \\
\end{tabular} & \begin{tabular}{|c|} 
DATA \\
Ground Motion at \\
Distance From \\
SGZ. Geophone \\
plots (yellow).
\end{tabular} & Program Leader Gayle Pawl & $\begin{array}{c}\text { SUMMARY AND FINAL } \\
\text { REPORTS } \\
\text { CONF=Classified CFRD } \\
\text { CDR=Containment Data } \\
\text { Report }\end{array}$ & $\begin{array}{l}\text { ski@|lnl.gov). } \\
\text { GAGE } \\
\text { LOCATIONS FOR } \\
\text { FREE SURFACE } \\
\text { AND FREE FIELD } \\
\text { DATA } \\
\text { RR=Round Robin } \\
\text { Surface gages } \\
\text { RTP=Recording } \\
\text { Trailer Park } \\
\text { ONI=Orientaion } \\
\text { to WP Not } \\
\text { Investigated }\end{array}$ \\
\hline TAMALPAIS & U12b.02 & \begin{tabular}{|l} 
LLNL, Pre- \\
BANEBERRY \\
\end{tabular} & None & None & None & None & None & $\begin{array}{l}\text { Shock Predictions for } \\
\text { Underground Nuclear } \\
\text { Explosions in Rainier Mesa } \\
\text { (U)", L. F. Ingram, J. L. } \\
\text { Drake, DNA-TR-88-14, } \\
\text { 10/23/87, . }\end{array}$ & $\begin{array}{l}\text { DASA and AEC report ITR- } \\
1711 \text { (ITR might stand for } \\
\text { Interagency Technical } \\
\text { Report) }\end{array}$ & $\begin{array}{l}\text { Subsurface, } 2 \\
\text { ERDL GM gages } \\
\text { (Ref.DNA-TR-88- } \\
\text { 14) }\end{array}$ \\
\hline TAPESTRY & U2an & $\begin{array}{l}\text { Sight (LOS) Pipe, } \\
\text { LLNL, Pre- } \\
\text { BANEBERRY }\end{array}$ & None & $\begin{array}{l}\text { CD of Compressed } \\
\text { Raw \& Processed } \\
\text { Data }\end{array}$ & None & $\begin{array}{l}4 \text { LOS Related } \\
\text { Data Rolls } \\
\text { (Green) }\end{array}$ & None & None & None & \\
\hline TARKO & U2fd & LLNL & None & $\begin{array}{l}\text { CD of Compressed } \\
\text { Raw \& Processed } \\
\text { Data; CD of ASCII } \\
\text { Processed Data; } 1 \\
\text { Binder (White) } \\
\text { Data Reduction, } 1 \\
\text { Binder (Yellow) } \\
\text { Analysis and Data } \\
\text { Reduction }\end{array}$ & 1 Folder & $\begin{array}{l}2 \text { Ground Motion } \\
\text { Rolls (Blue) ; } 1 \\
\text { Pres./ Radiation } \\
\text { Trace on Roll } \\
\text { (Red) ; 1 CLIPER } \\
\text { Printout Roll } \\
\text { (Blue) ; } 1 \text { set of } \\
\text { Data Listings } \\
\text { Channels } 0-12 \\
\end{array}$ & None & $\begin{array}{l}\text { Binder U (Peak } \\
\text { Accelleration of Trailers), } \\
\text { Binder T (CLIPER/EXCOR) }\end{array}$ & $\begin{array}{l}\text { Draft Report "Ground } \\
\text { Motion from TARKO } \\
\text { Event" and in Yellow } \\
\text { Binder Located in (E,b,2),; } \\
\text { UCRL-ID-127858 (CDR) }\end{array}$ & $\begin{array}{l}\text { Surface, Horiz. } \\
\text { Dist. 50' (Ref. } \\
\text { CDR): } \\
\text { Subsurface, No } \\
\text { free field gages, } \\
3 \text { GM gages in } \\
\text { Plugs (Ref. CDR) }\end{array}$ \\
\hline TEE & U2ab & $\begin{array}{l}\text { LLNL, Pre- } \\
\text { BANEBERRY }\end{array}$ & None & None & None & None & $\begin{array}{l}1 \text { Geophone Roll } \\
\text { (Yellow) }\end{array}$ & None & None & \\
\hline TELEME & U9cl & LLNL & 1 Binder & $\begin{array}{l}\text { CD of Compressed } \\
\text { Raw \& Processed } \\
\text { Data }\end{array}$ & 1 Folder & None & $\begin{array}{l}\text { Earth Strain } \\
\text { Cals.; PDS Cals. }\end{array}$ & Binder B & $\begin{array}{l}\text { CNSI report "Differential } \\
\text { Motion of the Pipe Across } \\
\text { the Decoupler in TELEMY } \\
\text { (U)", V. E. Wheeler/R. G. } \\
\text { Preston, UOPBA 75-107, } \\
6 / 6 / 75, \text {. CRD report } \\
\text { "Postoperational Report } \\
\text { for the Containment } \\
\text { Diagnostics in TELEME, } \\
\text { U9cl (U)", C. W. Olsen, } \\
\text { UOPBA } 75-98,5 / 20 / 75, . \\
\end{array}$ & $\begin{array}{l}\text { Surface, Possily } \\
\text { in Trailer Park. }\end{array}$ \\
\hline
\end{tabular}


Ground Motion Data: Appendix 3B (John Rambo)

\begin{tabular}{|c|c|c|c|c|c|c|c|c|c|c|}
\hline This dat & les in the LI & DNT Containmer & $\begin{array}{c}\text { DATA } \\
\text { Early LLNL } \\
\text { processed data } \\
\text { and reports }\end{array}$ & $\begin{array}{c}\text { DATA } \\
\begin{array}{c}\text { Later EG\&G } \\
\text { processed data and } \\
\text { reports }\end{array}\end{array}$ & $\begin{array}{c}\text { DATA } \\
-2 \text { Later data } \\
\begin{array}{c}\text { processed at LLNL } \\
\text { by EG\&G }\end{array}\end{array}$ & $\begin{array}{c}\text { 483, burkhard1 @ II } \\
\text { DATA } \\
\text { Data Plots, } \\
\text { Surface, } \\
\text { Subsurface } \\
\text { Ground Motion, } \\
\text { Pressure/ } \\
\text { Radiation } \\
\text { LOS/Displ./ Misc. } \\
\text { Similar Items are } \\
\text { included in this } \\
\text { column. }\end{array}$ & $\begin{array}{c}\text { DATA } \\
\text { Ground Motion at } \\
\text { Distance From } \\
\text { SGZ. Geophone } \\
\text { plots (yellow). }\end{array}$ & rogram Leader Gayle & $\begin{array}{c}\text { SUMMARY AND FINAL } \\
\text { REPORTS } \\
\text { CONF=Classified CFRD } \\
\begin{array}{c}\text { CDR=Containment Data } \\
\text { Report }\end{array}\end{array}$ & $\begin{array}{c}\text { ski@llnl.gov). } \\
\text { GAGE } \\
\text { LOCATIONS FOR } \\
\text { FREE SURFACE } \\
\text { AND FREE FIELD } \\
\text { DATA } \\
\text { RR=Round Robin } \\
\text { Surface gages } \\
\text { RTP=Recording } \\
\text { Trailer Park } \\
\text { ONI=Orientaion } \\
\text { to WP Not } \\
\text { Investigated }\end{array}$ \\
\hline TEMESCAL & U4ab & LLNL & 2 Binders & $\begin{array}{l}\text { CD of Compressed } \\
\text { Raw \& Processed } \\
\text { Data }\end{array}$ & 1 Folder & None & Earth Strain Cals. & None & $\begin{array}{l}\text { CRD report "Post- } \\
\text { Operational Report for the } \\
\text { Containment Diagnostics } \\
\text { on TEMESCAL, U4ab (U)", } \\
\text { C. W. Olsen, UOPBA } 74- \\
184,11 / 27 / 74, .\end{array}$ & \\
\hline TENABO & U20bb & & None & $\begin{array}{l}\text { CD of Compressed } \\
\text { Raw \& Processed } \\
\text { Data; CD of ASCII } \\
\text { Processed Data; } 1 \\
\text { Binder }\end{array}$ & 2 Folders & None & None & None & UCRL-MI-106506 (CDR) & $\begin{array}{l}\text { Surface, Horiz. } \\
\text { Dist.( No data) } \\
\text { (Ref. CDR): } \\
\text { Subsurface, No } \\
\text { free field } \\
\text { standard GM } \\
\text { gages, Close-in } \\
\text { instrument hole } \\
\text { peak values of } \\
\text { partical velocity } \\
\text { from } 2 \text { Kratz } \\
\text { gages and } 3 \\
\text { ASM gages, } 6 \\
\text { Dynasyn stress } \\
\text { gages, No GM } \\
\text { gages in Plugs }\end{array}$ \\
\hline $\begin{array}{l}\text { TERRINE WHITE or } \\
\text { TERRINE YELLOWW }\end{array}$ & $\begin{array}{l}\text { U9bi } 1 \text { or U9bi } \\
2\end{array}$ & $\begin{array}{l}\text { UIIKIIUwil ds LU } \\
\text { which event, } \\
\text { perhaps both, } \\
\text { affected the data. } \\
\text { LLNL, Pre- } \\
\text { BANEBERRY }\end{array}$ & None & & None & None & None & None & 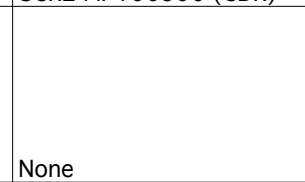 & \\
\hline TIERRA & U19ac & LLNL & None & $\begin{array}{l}\text { CD of Compressed } \\
\text { Raw \& Processed } \\
\text { Data } \\
\end{array}$ & 1 Folder & None & None & 4 Presentation Binders & None & \\
\hline
\end{tabular}


Ground Motion Data: Appendix 3B (John Rambo)

\begin{tabular}{|c|c|c|c|c|c|c|c|c|c|c|}
\hline Inis datá & HOLE & COMMENTS & $\begin{array}{c}\text { DATA } \\
\text { Early LLNL } \\
\text { processed data } \\
\text { and reports }\end{array}$ & $\begin{array}{c}\text { DATA } \\
-\begin{array}{c}\text { Later EG\&G } \\
\text { processed data and } \\
\text { reports }\end{array}\end{array}$ & $\begin{array}{c}\text { DATA } \\
\text { Later data } \\
\text { processed at LLNL } \\
\text { by EG\&G }\end{array}$ & \begin{tabular}{|c|} 
DATA \\
Data Plots, \\
Surface, \\
Subsurface \\
Ground Motion, \\
Pressure/ \\
Radiation \\
LOS/Displ./ Misc. \\
Similar Items are \\
included in this \\
column.
\end{tabular} & \begin{tabular}{|c|} 
DATA \\
Ground Motion at \\
Distance From \\
SGZ. Geophone \\
plots (yellow).
\end{tabular} & 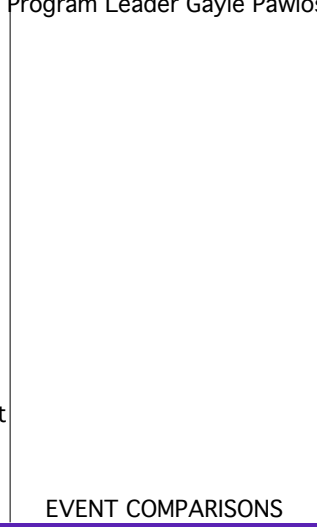 & $\begin{array}{c}\text { SUMMARY AND FINAL } \\
\text { REPORTS } \\
\text { CONF=Classified CFRD } \\
\text { CDR=Containment Data } \\
\text { Report }\end{array}$ & $\begin{array}{l}\text { GAGE } \\
\text { LOCATIONS FOR } \\
\text { FREE SURFACE } \\
\text { AND FREE FIELD } \\
\text { DATA } \\
\text { RR=Round Robin } \\
\text { Surface gages } \\
\text { RTP=Recording } \\
\text { Trailer Park } \\
\text { ONl=Orientaion } \\
\text { to WP Not } \\
\text { Investigated }\end{array}$ \\
\hline & U4ak & LLNL & None & \begin{tabular}{|l|} 
CD of Compressed \\
Raw \& Processed \\
Data; CD of ASCII \\
Processed Data; 1 \\
Binder
\end{tabular} & 1 Folder & None & None & $\begin{array}{l}\text { "Analysis of Near Field } \\
\text { Ground Motion from } \\
\text { Nuclear Detonations in } \\
\text { High Porosity Media, R. T. } \\
\text { Terhune, M. Heusinkveld, } \\
\text { Proceedings of the Second } \\
\text { Symposium of } \\
\text { Underground Nuclear } \\
\text { Explosions, Albuquerque } \\
\text { NM, } 8 / 2-4 / 83, \text { Vol2 }\end{array}$ & \begin{tabular}{|l|} 
\\
\\
Draft Report "Data \\
Report, TILCI Event: \\
Motion in the Free Field" ; \\
UCRL 53318 (S), UCRL-ID- \\
127717 (CDR)
\end{tabular} & \begin{tabular}{|l} 
Surface, Horiz. \\
Dist. 50' (Ref. \\
CDR): \\
Subsurface, Free \\
field gages, 10 \\
vertical offset \\
GM gages, 11 \\
vertical offset \\
stress gages, No \\
GM gages in \\
Plugs (Ref. CDR)
\end{tabular} \\
\hline $\begin{array}{l}\text { TOMME/MIDNIGHT } \\
\text { ZEPHER }\end{array}$ & U12n.18 & DOD/LLNL & None & & 1 Folder & None & None & None & 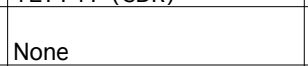 & \\
\hline TOPGALLANT & U4e & LANL & None & $\begin{array}{l}\text { CD of Compressed } \\
\text { Raw \& Processed } \\
\text { Data }\end{array}$ & None & None & $\begin{array}{l}\text { Earth Strain Cals. } \\
\text {; Pathfinder II }\end{array}$ & None & None & \\
\hline TRUMBULL & U4aa & LLNL & 2 Binders & $\begin{array}{l}\text { CD of Compressed } \\
\text { Raw \& Processed } \\
\text { Data }\end{array}$ & 1 Folder & None & Earth Strain Cals. & Binder B & $\begin{array}{l}\text { the PINEX Pipe and } \\
\text { Stemming in Trumbull } \\
\text { (U)", V. E. Wheeler/R. G. } \\
\text { Preston, UOPBA 75-58, } \\
\text { 9/22/75. CFRD report } \\
\text { "Post-Operational Report } \\
\text { for the Containment } \\
\text { Diagnostics on } \\
\text { TRUMBULL, U4aa (U)", C. } \\
\text { W. Olsen, UOPBA 74-178, } \\
\text { 11/14/75. } \\
\end{array}$ & \begin{tabular}{|l} 
\\
Surface, Hor. \\
Dist. 61' (Ref. \\
UOPBA 75-58)
\end{tabular} \\
\hline TUB & U10aj & $\begin{array}{l}\text { LLNL, Pre- } \\
\text { BANEBERRY }\end{array}$ & & 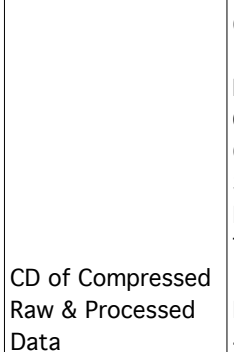 & \begin{tabular}{|l|} 
CONF report \\
"Proposal for \\
Individual Cavity \\
Collapse \\
Observation from \\
Simultaneous \\
Detonation of the \\
TUB Event, U10aj \\
(U)", R. T. Stearns, \\
Nevada: LRL Memo, \\
4/3/68,.
\end{tabular} & None & None & None & None & \\
\hline
\end{tabular}


Ground Motion Data: Appendix 3B (John Rambo)

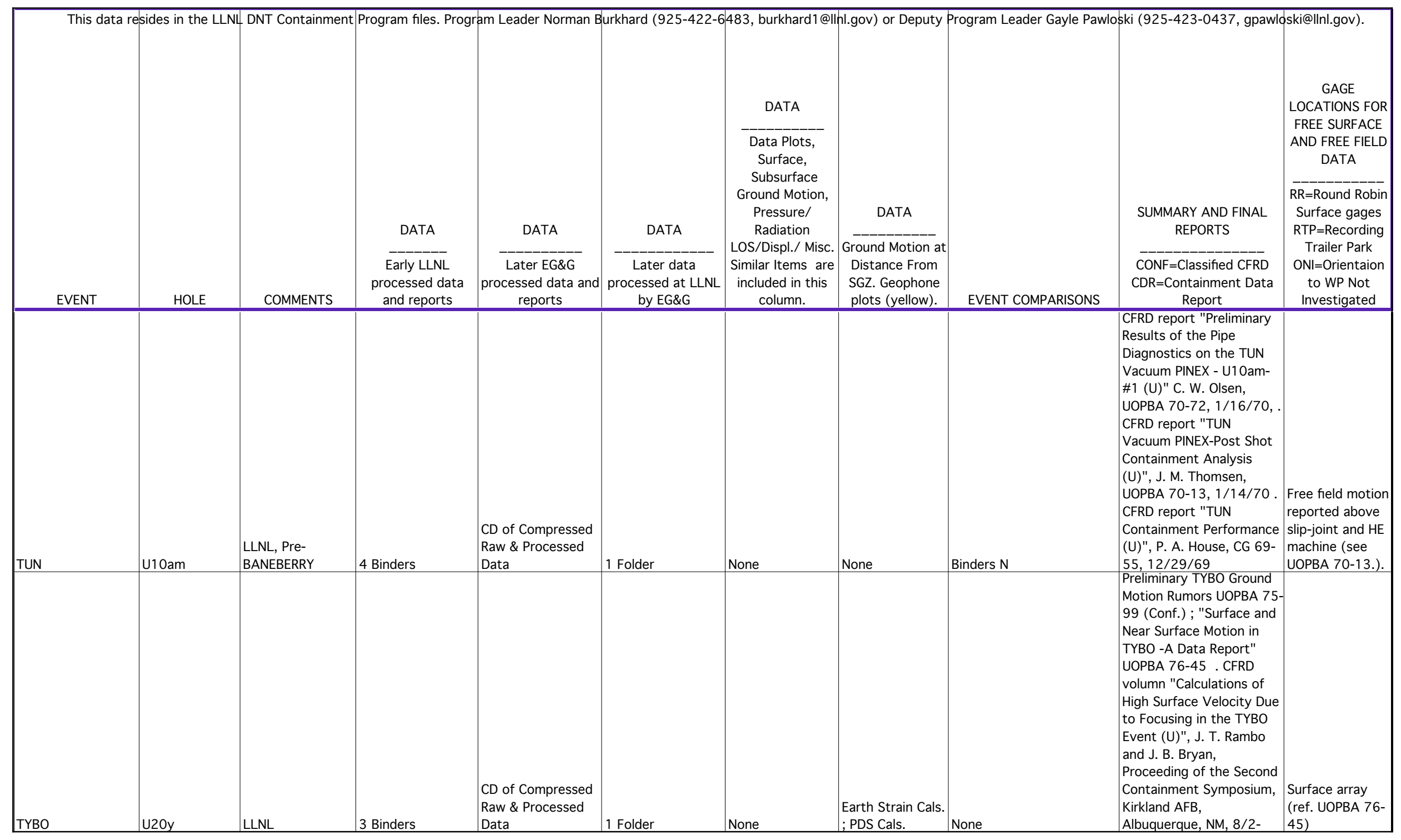


Ground Motion Data: Appendix 3B (John Rambo)

\begin{tabular}{|c|c|c|c|c|c|c|c|c|c|c|}
\hline This da & les in the $\mathrm{LL}$ & DNI Contanme & $\begin{array}{c}\text { DATA } \\
\text { Early LLNL } \\
\text { processed data } \\
\text { and reports }\end{array}$ & $\begin{array}{c}\text { DATA } \\
\text { Later EG\&G } \\
\begin{array}{c}\text { processed data and } \\
\text { reports }\end{array}\end{array}$ & $\begin{array}{c}\text { DATA } \\
- \text { Later data } \\
\begin{array}{c}\text { processed at LLNL } \\
\text { by EG\&G }\end{array}\end{array}$ & \begin{tabular}{|c|} 
DATA \\
Data Plots, \\
Surface, \\
Subsurface \\
Ground Motion, \\
Pressure/ \\
Radiation \\
LOS/Displ./ Misc. \\
Similar Items are \\
included in this \\
column.
\end{tabular} & $\begin{array}{c}\text { DATA } \\
\text { Ground Motion at } \\
\text { Distance From } \\
\text { SGZ. Geophone } \\
\text { plots (yellow). }\end{array}$ & (1) & $\begin{array}{c}\text { SUMMARY AND FINAL } \\
\text { REPORTS } \\
\overline{\text { CONF=Classified CFRD }} \\
\text { CDR=Containment Data } \\
\text { Report }\end{array}$ & $\begin{array}{l}\text { ski@llnl.gov). } \\
\text { GAGE } \\
\text { LOCATIONS FOR } \\
\text { FREE SURFACE } \\
\text { AND FREE FIELD } \\
\text { DATA } \\
\text { RR=Round Robin } \\
\text { Surface gages } \\
\text { RTP=Recording } \\
\text { Trailer Park } \\
\text { ONI=Orientaion } \\
\text { to WP Not } \\
\text { Investigated }\end{array}$ \\
\hline TYG A through $\mathrm{E}$ & $\begin{array}{l}\text { U2dc } 1 \text { through } \\
5\end{array}$ & $\begin{array}{l}\text { instrumented } \\
\text { across various } \\
\text { TYG events fired } \\
\text { at nearly the } \\
\text { same time. } \\
\text { Unknown as to } \\
\text { which events, } \\
\text { perhaps part or } \\
\text { all, affected the } \\
\text { data. LLNL, Pre- } \\
\text { BANEBERRY }\end{array}$ & None & & None & \begin{tabular}{|l|}
1 Misc. Data Roll \\
on TYG locations \\
(possibly \\
geophone). \\
(Green)
\end{tabular} & $\begin{array}{l}11 \text { Geophone } \\
\text { Rolls. NOTE: Rolls } \\
\text { need to be } \\
\text { properly } \\
\text { associated to } \\
\text { the proper TYG } \\
\text { hole. (Yellow) } \\
\end{array}$ & None & $\begin{array}{l}\text { CFRD report "A Surface } \\
\text { Motion Experiment on the } \\
\text { TYG Event (U)", B. C. } \\
\text { Hudson and J. B. Bryan, } \\
\text { UOPBA-53, 4/22/69 }\end{array}$ & $\begin{array}{l}\text { Surface flares } \\
\text { instrumented } \\
\text { across various } \\
\text { TYG events fired } \\
\text { at nearly the } \\
\text { same time. (Ref. } \\
\text { UOPBA-53 or try } \\
\text { UOPBA } 69-53 \text { ) }\end{array}$ \\
\hline $\begin{array}{l}\text { VAUGHN } \\
\text { VERMEJO }\end{array}$ & \begin{tabular}{|l} 
U3hr \\
U4r
\end{tabular} & $\begin{array}{l}\text { LANL } \\
\text { LANL }\end{array}$ & \begin{tabular}{|l|} 
None \\
None
\end{tabular} & $\begin{array}{l}\text { CD of Compressed } \\
\text { Raw \& Processed } \\
\text { Data; CD of ASCII } \\
\text { Processed Data } \\
\text { None }\end{array}$ & \begin{tabular}{|l|} 
None \\
1 Folder
\end{tabular} & \begin{tabular}{|l|} 
None \\
None
\end{tabular} & \begin{tabular}{|l} 
None \\
None
\end{tabular} & \begin{tabular}{|l} 
None \\
None
\end{tabular} & $\begin{array}{l}\text { None } \\
\text { None }\end{array}$ & \\
\hline VIDE & U8k & LLNL & None & $\begin{array}{l}\text { CD of Compressed } \\
\text { Raw \& Processed } \\
\text { Data; CD of ASCII } \\
\text { Processed Data; } 1 \\
\text { Binder } \\
\end{array}$ & 1 Folder & \begin{tabular}{|l|} 
\\
1 set of Data \\
Listings Channels \\
$0-19,1$ CLIPER \\
Printout (Blue) \\
\end{tabular} & \begin{tabular}{|l|} 
Pathfinder CD \\
with interaction \\
measurment \\
made at VIDE \\
from an unknown \\
event source. \\
\end{tabular} & Binder T (CLIPER/EXCOR) & $\begin{array}{l}\text { Draft Report "Motion } \\
\text { Measured on the VIDE } \\
\text { Event" ; UOPKL 82-85 } \\
\text { (S); UCRL-ID-125022 } \\
\text { (CDR) }\end{array}$ & $\begin{array}{l}\text { Dist. 50', } 14 \\
\text { other surface } \\
\text { gages, see } \\
\text { report for horiz. } \\
\text { Distance. (Ref. } \\
\text { CDR): } \\
\text { Subsurface, No } \\
\text { free field gages, } \\
3 \text { GM gages in } \\
\text { Plugs (Ref. CDR) }\end{array}$ \\
\hline VILLE & U4am & LLNL & None & $\begin{array}{l}\text { CD of Compressed } \\
\text { Raw \& Processed } \\
\text { Data; CD of ASCII } \\
\text { Processed Data; } 1 \\
\text { Binder } \\
\end{array}$ & 2 Folders & \begin{tabular}{|l|}
1 Pres./ Radiation \\
Printout Roll \\
(Red)
\end{tabular} & None & $\begin{array}{l}\text { Binder X, Binder U (Peak } \\
\text { Accelleration of Trailers), } \\
\text { Binder T (CLIPER/EXCOR), } \\
6 \text { Presentation Binders } \\
\end{array}$ & UCRL-ID-120666 (CDR) & $\begin{array}{l}\text { Dist. 50' (Ref. } \\
\text { CDR): } \\
\text { Subsurface, No } \\
\text { free field gages, } \\
2 \text { GM gages in } \\
\text { Plugs, stress } \\
\text { gages in plugs } \\
\text { (Ref. CDR) } \\
\end{array}$ \\
\hline
\end{tabular}


Ground Motion Data: Appendix 3B (John Rambo)

\begin{tabular}{|c|c|c|c|c|c|c|c|c|c|c|}
\hline This c & ente & ent & . & $\begin{array}{c}\text { DATA } \\
\text { Later EG\&G } \\
\begin{array}{c}\text { processed data and } \\
\text { reports }\end{array}\end{array}$ & $\begin{array}{c}\text { DATA } \\
\text { Later data } \\
\begin{array}{c}\text { processed at LLNL } \\
\text { by EG\&G }\end{array}\end{array}$ & $\begin{array}{c}\text { DATA } \\
\text { - Data Plots, } \\
\text { Surface, } \\
\text { Subsurface } \\
\text { Ground Motion, } \\
\text { Pressure/ } \\
\text { Radiation } \\
\text { LOS/Displ./ Misc. } \\
\text { Similar Items are } \\
\text { included in this } \\
\text { column. }\end{array}$ & \begin{tabular}{|c|} 
DATA \\
Ground Motion at \\
Distance From \\
SGZ. Geophone \\
plots (yellow).
\end{tabular} & (n) & $\begin{array}{c}\text { SUMMARY AND FINAL } \\
\text { REPORTS } \\
\text { CONF=Classified CFRD } \\
\text { CDR=Containment Data } \\
\text { Report }\end{array}$ & $\begin{array}{c}\text { GAGE } \\
\text { LOCATIONS FOR } \\
\text { FREE SURFACE } \\
\text { AND FREE FIELD } \\
\text { DATA } \\
\text { RR=Round Robin } \\
\text { Surface gages } \\
\text { RTP=Recording } \\
\text { Trailer Park } \\
\text { ONI=Orientaion } \\
\text { to WP Not } \\
\text { Investigated }\end{array}$ \\
\hline VULCAN & U2bd & \begin{tabular}{|l} 
LLNL, Pre- \\
BANEBERRY
\end{tabular} & 1 Binder & $\begin{array}{l}\text { CD of Compressed } \\
\text { Raw \& Processed } \\
\text { Data }\end{array}$ & None & None & None & $\begin{array}{l}1 \text { Presentation Binder . } \\
\text { CFRD report "Peak Surface } \\
\text { Velocity from Nuclear } \\
\text { Explosions (U)", V. E. } \\
\text { Wheeler, UOPBA 73-44, } \\
3 / 16 / 73, \text {. CFRD report } \\
\text { "Summary of Free Field } \\
\text { Ground Motion } \\
\text { Measurements (U)", V. E. } \\
\text { Wheeler/ R. G. Preston, } \\
\text { UOPBA 74-126, 8/21/74, } \\
\text {. CFRD report "Scaled Free- } \\
\text { Field Peak Radial Stresses } \\
\text { from Underground Nuclear } \\
\text { Explosiona in Five Explosion } \\
\text { Media (U)", V. E. Wheeler/ } \\
\text { R. G. Preston, UOPKG 66- } \\
\text { 80, 12,/7/66, } \\
\end{array}$ & $\begin{array}{l}\text { I } \\
\text { LLNL/Nortronics report, } \\
\text { Randolph, Preston, and } \\
\text { Wheeler, UCID-15051. }\end{array}$ & $\begin{array}{l}\text { Surface, Hor. } \\
\text { dist. (NI) (Ref. } \\
\text { UOPBA 73-44); } \\
\text { Subsurface 10 } \\
\text { GM gages (Ref. } \\
\text { UOPBA 74-126) }\end{array}$ \\
\hline WALLER & U2bz & LLNL & 1 Binder & $\begin{array}{l}\text { CD of Compressed } \\
\text { Raw \& Processed } \\
\text { Data }\end{array}$ & None & None & None & Binders $\mathrm{B}, \mathrm{H}, \mathrm{K}, \mathrm{M}$ & $\begin{array}{l}\text { CFRD report "Post- } \\
\text { operational Report of the } \\
\text { Containment Diagnostics } \\
\text { on WALLER, U2bz (U)", C. } \\
\text { W. Olsen, UOPBA 74-25, } \\
\text { 2/25/73. . CFRD report } \\
\text { "Response of the PINEX } \\
\text { Pipe in WALLER (U)", V. E. } \\
\text { Wheeler/ R. G. Preston, } \\
\text { UOPBA 74-136, 9/5/74 }\end{array}$ & \begin{tabular}{|l|} 
\\
\\
Free Field \\
Surface GM gage \\
in trailer park \\
$312 \mathrm{~m}$ \\
horizontal range.
\end{tabular} \\
\hline WASHER & U10r & $\begin{array}{l}\text { LLNL, Pre- } \\
\text { BANEBERRY }\end{array}$ & None & $\begin{array}{l}\text { CD of Compressed } \\
\text { Raw \& Processed } \\
\text { Data }\end{array}$ & None & None & None & None & None & \\
\hline WEXFORD & $\mathrm{U} 2 \mathrm{cr}$ & LLNL & None & $\begin{array}{l}\text { CD of Compressed } \\
\text { Raw \& Processed } \\
\text { Data ; CD of ASCII } \\
\text { Processed Data ; } 1 \\
\text { Binder }\end{array}$ & 2 Folders & $\begin{array}{l}5 \text { Rolls of Ground } \\
\text { Motion; } 2 \text { Rolls of } \\
\text { Pressure and } \\
\text { Radiation (all } \\
\text { items in one Box } \\
\end{array}$ & None & $\begin{array}{l}\text { Binder X, Binder U (Peak } \\
\text { Accelleration of Trailers), } \\
\text { Binder T (CLIPER/EXCOR), } \\
2 \text { Presentation Binders } \\
\end{array}$ & $\begin{array}{l}\text { Draft Report } \\
\text { "Containment } \\
\text { Measurements Taken on } \\
\text { the WEXFORD Event, Final } \\
\text { Report" ; UCRL-ID- } \\
121265 \text { (CDR) } \\
\end{array}$ & $\begin{array}{l}\text { Dist. 50', RTP } \\
\text { (Ref. CDR): } \\
\text { Subsurface, No } \\
\text { free field gages, } \\
2 \text { GM gages in } \\
\text { Plugs (Ref. CDR) } \\
\end{array}$ \\
\hline
\end{tabular}


Ground Motion Data: Appendix 3B (John Rambo)

\begin{tabular}{|c|c|c|c|c|c|c|c|c|c|c|}
\hline 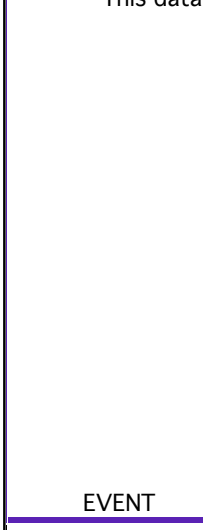 & HOLE & COMMENTS & $\begin{array}{c}\text { DATA } \\
\text { Early LLNL } \\
\text { processed data } \\
\text { and reports } \\
\end{array}$ & $\begin{array}{c}\text { DATA } \\
\begin{array}{c}\text { Later EG\&G } \\
\text { processed data and } \\
\text { reports }\end{array} \\
\end{array}$ & \begin{tabular}{|c|} 
DATA \\
Later data \\
processed at LLNL \\
by EG\&G
\end{tabular} & \begin{tabular}{|c|} 
DATA \\
Data Plots, \\
Surface, \\
Subsurface \\
Ground Motion, \\
Pressure/ \\
Radiation \\
LOS/Displ./ Misc. \\
Similar Items are \\
included in this \\
column.
\end{tabular} & \begin{tabular}{|c|} 
DATA \\
Ground Motion at \\
Distance From \\
SGZ. Geophone \\
plots (yellow).
\end{tabular} & 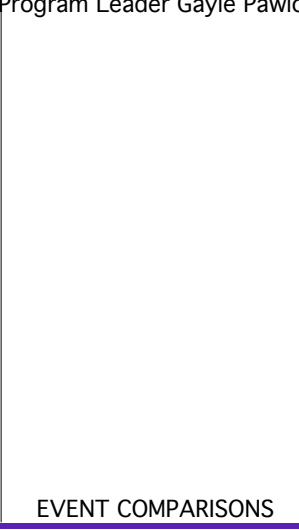 & $\begin{array}{c}\text { SUMMARY AND FINAL } \\
\text { REPORTS } \\
\text { CONF=Classified CFRD } \\
\text { CDR=Containment Data } \\
\text { Report }\end{array}$ & $\begin{array}{c}\text { ski@llnl.gov). } \\
\text { GAGE } \\
\text { LOCATIONS FOR } \\
\text { FREE SURFACE } \\
\text { AND FREE FIELD } \\
\text { DATA } \\
\text { RR=Round Robin } \\
\text { Surface gages } \\
\text { RTP=Recording } \\
\text { Trailer Park } \\
\text { ONI=Orientaion } \\
\text { to WP Not } \\
\text { Investigated }\end{array}$ \\
\hline VAUGHN & U3lr & LANL & None & None & None & None & \begin{tabular}{|l|} 
atnnnaer $\mathrm{CU}$ \\
with interaction \\
measurment \\
made at \\
COTTAGE
\end{tabular} & None & None & \\
\hline VILLITA & U3ld & LANL & None & None & None & None & $\begin{array}{l}\text { Patnnnder CD } \\
\text { with interaction } \\
\text { measurment } \\
\text { made at } \\
\text { COTTAGE }\end{array}$ & None & None & \\
\hline YANNIGAN BLUE & U2ay 3 & $\begin{array}{l}\text { LLNL, Pre- } \\
\text { BANEBERRY }\end{array}$ & None & $\begin{array}{l}\text { CD of Compressed } \\
\text { Raw \& Processed } \\
\text { Data }\end{array}$ & 1 Folder & None & None & None & None & \\
\hline YERBA & U1c & LANL & None & None & None & None & $\begin{array}{l}\text { "Round Robin } \\
\text { Program YERBA } \\
\text { Event (U)", W. R. } \\
\text { Perret, Sandia } \\
\text { UOPBA 72-23, } \\
\text { 2/7/72 (V). } \\
\end{array}$ & $\begin{array}{l}\text { CFRD report "Peak Surface } \\
\text { Velocity from Nuclear } \\
\text { Explosions (U)", V. E. } \\
\text { Wheeler, UOPBA } 73-44, \\
3 / 16 / 73 \text {, }\end{array}$ & None & $\begin{array}{l}\text { Surface (Ref. } \\
\text { RR) Horiz., 51', } \\
540^{\prime}, 541^{\prime}, 541^{\prime}\end{array}$ \\
\hline ZINNIA & U2dk & LLNL & 3 Binders & 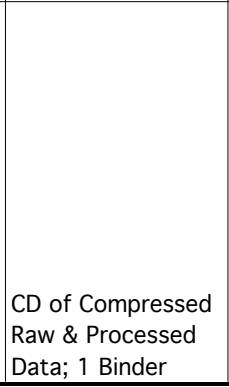 & 1 Folder & None & $\begin{array}{l}1 \text { Wide } \\
\text { Geophone Roll } \\
\text { (Yellow) }\end{array}$ & $\begin{array}{l}\text { CFRD report "Trapped } \\
\text { Stress Waves in } \\
\text { Underground Nuclear } \\
\text { Explosions (U)", V. E. } \\
\text { Wheeler, R. G. Preston, C. } \\
\text { E. Frerking, UCRL-52012, . } \\
\text { CFRD report "Summary of } \\
\text { Free Field Ground Motion } \\
\text { Measurements (U)", V. E. } \\
\text { Wheeler/ R. G. Preston, } \\
\text { UOPBA 74-126, 8/21/74, } \\
\end{array}$ & $\begin{array}{l}\text { Draft Report "Response of } \\
\text { the Pipe in ZINNIA" }\end{array}$ & $\begin{array}{l}\text { Subsurface } \\
\text { stemming gages } \\
\text { (Ref. UOPBA 74- } \\
126)\end{array}$ \\
\hline
\end{tabular}

